\title{
Metal Borohydrides beyond Groups I and II: A Review
}

\author{
Karina Suárez-Alcántara * and Juan Rogelio Tena García
}

check for updates

Citation: Suárez-Alcántara, K.; Tena García, J.R. Metal Borohydrides beyond Groups I and II: A Review. Materials 2021, 14, 2561. https:// doi.org/10.3390/ma14102561

Academic Editor: Oksana V. Komova

Received: 5 April 2021

Accepted: 8 May 2021

Published: 14 May 2021

Publisher's Note: MDPI stays neutral with regard to jurisdictional claims in published maps and institutional affiliations.

Copyright: (c) 2021 by the authors. Licensee MDPI, Basel, Switzerland. This article is an open access article distributed under the terms and conditions of the Creative Commons Attribution (CC BY) license (https:/ / creativecommons.org/licenses/by/ $4.0 /)$.
Morelia Unit of Materials Institute Research, National Autonomous University of Mexico, Morelia, Michoacán 58190, Mexico; kse_91@hotmail.com

* Correspondence: karina_suarez@iim.unam.mx; Tel.: +52-55-5623-7300 (ext. 37889)

\begin{abstract}
This review consists of a compilation of synthesis methods and several properties of borohydrides beyond Groups I and II, i.e., transition metals, main group, lanthanides, and actinides. The reported properties include crystal structure, decomposition temperature, ionic conductivity, photoluminescence, etc., when available. The compiled properties reflect the rich chemistry and possible borohydrides' application in areas such as hydrogen storage, electronic devices that require an ionic conductor, catalysis, or photoluminescence. At the end of the review, two short but essential sections are included: a compilation of the decomposition temperature of all reported borohydrides versus the Pauling electronegativity of the cations, and a brief discussion of the possible reactions occurring during diborane emission, including some strategies to reduce this inconvenience, particularly for hydrogen storage purposes.
\end{abstract}

Keywords: borohydrides; transition metals; lanthanides

\section{Introduction}

To date, several reviews on the alkali or alkali earth metal borohydrides for hydrogen storage have been published [1,2]. This great interest is due to the high hydrogen content of some of them, e.g., $\mathrm{LiBH}_{4}$. However, other metal borohydrides can be important for several applications, including, but not limited to, hydrogen storage. For example, the transition metal borohydrides present dehydrogenation temperatures which are usually lower than those of Group I and Group II borohydrides. In some cases, the hydrogen content is interesting $(6-8 \mathrm{wt} . \%)$ due to the oxidation states $(+2,+3)$ that translate into a high number of $\left[\mathrm{BH}_{4}\right]^{-1}$ ions (ligands) [3] (See Figure 1). Recently, bimetallic and trimetallic materials with high hydrogen content have emerged (See Figure 2). Non- alkali or alkali earth metal borohydrides have many exciting characteristics that can help design new materials and applications beyond hydrogen storage. For example, lately, borohydrides have gained attention as high-temperature conductors in the solid-state or even when melted [4-6]. Borohydrides can also act as precursors to the corresponding metal boride [7-10] for the CVD-growing of thin films [11,12]. Rare earth metal borohydrides are emerging as new materials [13] for ion conductivity [5,14], catalysis [15,16], luminescence $[17,18]$, or magnetic $[19,20]$ applications. 


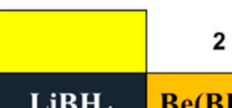

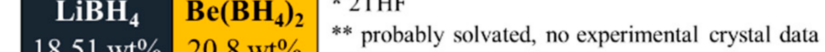

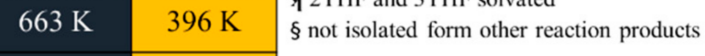

$\mathrm{NaBH}_{4} \quad \mathrm{Mg}\left(\mathrm{BH}_{4}\right)_{2}$

$3 \quad 10.66 \mathrm{wt}^{\circ} \quad 14.9 \mathrm{wt} \%$

$\begin{array}{ll}773 \mathrm{~K} & 572 \mathrm{~K}\end{array}$

$\mathrm{KBH}_{4} \mathrm{Ca}\left(\mathrm{BH}_{4}\right)$

$7.47 \mathrm{wt} \%$

$823 \mathrm{~K}$

$\mathrm{RbBH}_{4}$

5

\begin{tabular}{l|l|l|l|l}
$773 \mathrm{~K}$ & $653 \mathrm{~K}$ & $460 \mathrm{~K}$ & $355 \mathrm{~K}$
\end{tabular}

\begin{tabular}{ll|l}
$\mathrm{CsBH}_{4}$ & $\mathrm{Ba}\left(\mathrm{BH}_{4}\right)_{2}$ & $\mathrm{Hf}\left(\mathrm{BH}_{4}\right)_{4}$
\end{tabular}

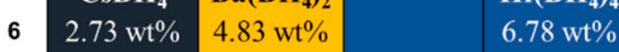

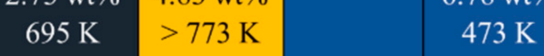

7

18

13

$\begin{array}{llll}14 & 15 & 16 & 17\end{array}$

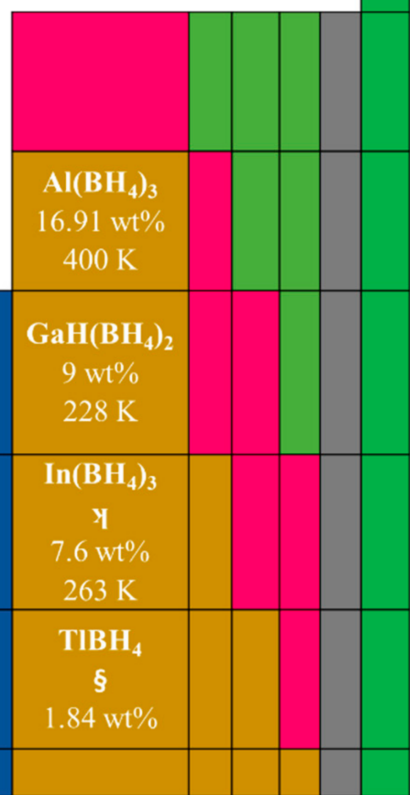

\begin{tabular}{|c|c|c|c|c|c|c|c|c|c|c|c|c|c|c|}
\hline $\begin{array}{c}\mathbf{L a}\left(\mathbf{B H}_{4}\right)_{3} \\
6.6 \mathrm{wt} \% \\
523-573 \mathrm{~K}\end{array}$ & $\begin{array}{c}\mathbf{C e}\left(\mathbf{B H}_{4}\right)_{3} \\
6.55 \mathrm{wt} \% \\
498-563 \mathrm{~K}\end{array}$ & $\begin{array}{c}\mathbf{P r}\left(\mathbf{B H}_{4}\right)_{3} \\
6.52 \mathrm{wt} \% \\
520-533 \mathrm{~K}\end{array}$ & $\begin{array}{c}\mathbf{N d}\left(\mathbf{B H}_{4}\right)_{3} \\
6.41 \mathrm{wt} \% \\
523 \mathrm{~K}\end{array}$ & & \begin{tabular}{|c|}
$\mathrm{Sm}\left(\mathrm{BH}_{4}\right)_{2}$ \\
$4.48 \mathrm{wt} \%$ \\
$608 \mathrm{~K}$ \\
\\
$\mathrm{Sm}\left(\mathrm{BH}_{4}\right)_{3}$ \\
$6.21 \mathrm{wt} \%$ \\
$473 \mathrm{~K}$
\end{tabular} & \begin{tabular}{|c}
$\mathbf{E u}\left(\mathbf{B H}_{4}\right)_{2}$ \\
$4.44 \mathrm{wt} \%$ \\
$668 \mathrm{~K}$ \\
\\
$\mathbf{E u}\left(\mathbf{B H}_{4}\right)_{3}$ \\
$6.16 \mathrm{wt}^{2} \%$ \\
$298 \mathrm{~K}$
\end{tabular} & $\begin{array}{c}\mathbf{G d}\left(\mathbf{B H}_{4}\right)_{3} \\
5.99 \mathrm{wt} \% \\
508-543 \mathrm{~K}\end{array}$ & $\begin{array}{c}\mathbf{T b}\left(\mathbf{B H}_{4}\right)_{3} \\
5.95 \mathrm{wt} \% \\
>523 \mathrm{~K}\end{array}$ & $\begin{array}{c}\mathbf{D y}\left(\mathbf{B H}_{4}\right)_{3} \\
5.84 \mathrm{wt} \% \\
>523 \mathrm{~K}\end{array}$ & $\begin{array}{c}\mathbf{H o}\left(\mathbf{B H}_{4}\right)_{3} \\
5.77 \mathrm{wt} \% \\
523 \mathrm{~K}\end{array}$ & $\begin{array}{c}\mathbf{E r}\left(\mathbf{B H}_{4}\right)_{3} \\
5.71 \mathrm{wt} \% \\
559 \mathrm{~K}\end{array}$ & $\begin{array}{c}\mathbf{T m}\left(\mathbf{B H}_{4}\right)_{3} \\
5.71 \mathrm{wt} \% \\
>523 \mathrm{~K}\end{array}$ & $\begin{array}{c}\mathbf{Y b}\left(\mathbf{B H}_{4}\right)_{3} \\
5.56 \mathrm{wt} \% \\
618 \mathrm{~K} \\
\\
\mathbf{Y b}\left(\mathbf{B H}_{4}\right)_{2} \\
3.98 \mathrm{wt} \%\end{array}$ & $\begin{array}{l}\mathbf{L u}\left(\mathbf{B H}_{4}\right)_{3} \\
3.94 \mathrm{wt}^{2} \%\end{array}$ \\
\hline & $\begin{array}{l}\mathbf{T h}\left(\mathbf{B H}_{4}\right)_{4} \\
5.53 \mathrm{wt} \%\end{array}$ & $\begin{array}{l}\mathbf{P a}\left(\mathbf{B H}_{4}\right)_{4} \\
5.55 \mathrm{wt} \%\end{array}$ & $\begin{array}{c}\mathbf{U}\left(\mathbf{B H}_{4}\right)_{4} \\
5.42 \mathrm{wt} \% \\
373-423 \mathrm{~K}\end{array}$ & $\begin{array}{c}\mathbf{N p}\left(\mathbf{B H}_{4}\right)_{3} \\
4.3 \mathrm{wt} \% \\
298 \mathrm{~K}\end{array}$ & \begin{tabular}{|c|}
$\mathbf{P u}\left(\mathbf{B H}_{4}\right)_{3}$ \\
$4.19 \mathrm{wt}^{2} \%$ \\
$293 \mathrm{~K}$
\end{tabular} & & & & & & & & & \\
\hline
\end{tabular}

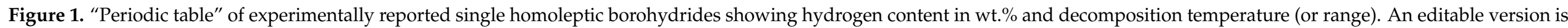
in the supplementary file. 


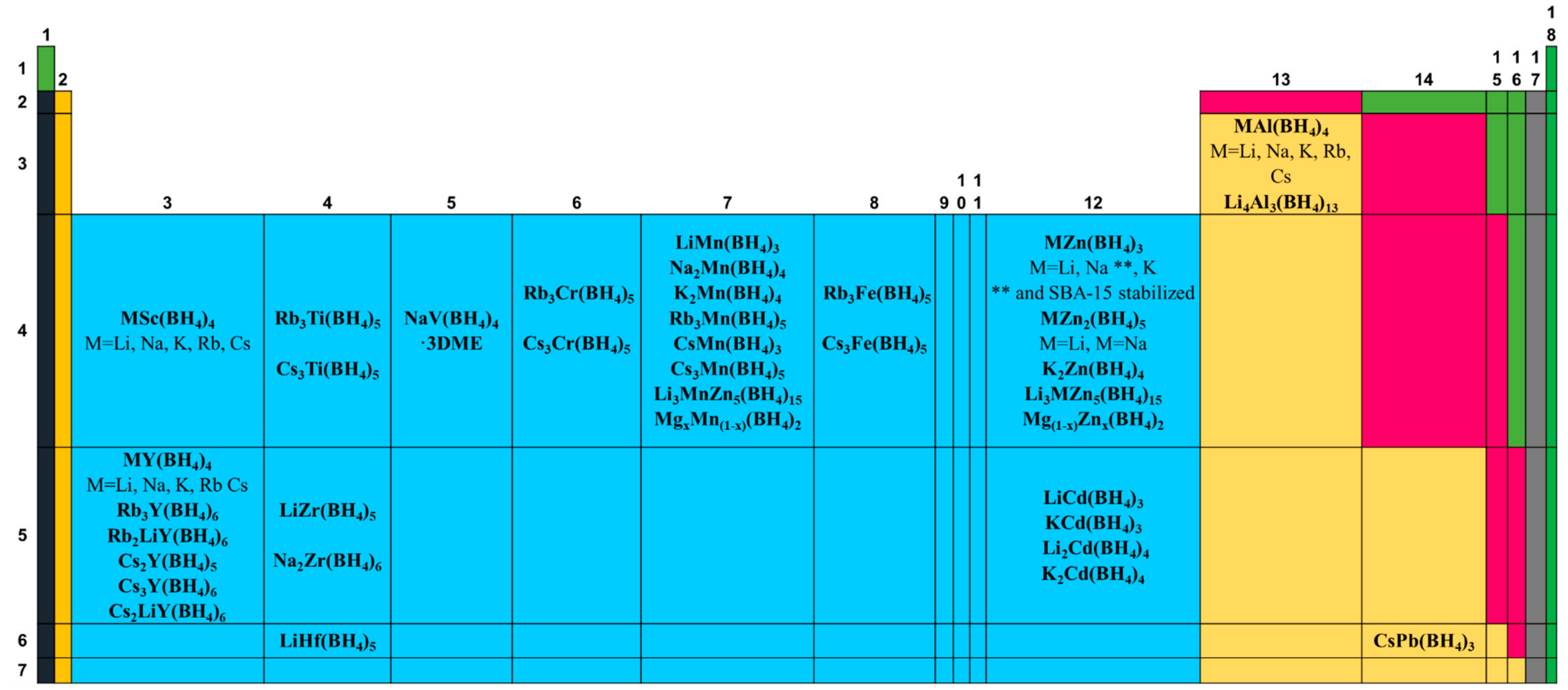

\begin{tabular}{|c|c|c|c|c|c|c|c|c|}
\hline $\begin{array}{c}\mathrm{NaLa}\left(\mathrm{BH}_{4}\right)_{4} \\
\mathrm{~K}_{3} \mathrm{La}\left(\mathrm{BH}_{4}\right)_{6} \\
\mathrm{Li}_{3} \mathrm{~K}_{3} \mathrm{La}_{2}\left(\mathrm{BH}_{4}\right)_{12}\end{array}$ & $\begin{array}{c}\mathrm{NaCe}\left(\mathrm{BH}_{4}\right)_{4} \\
\mathrm{~K}_{3} \mathrm{Ce}\left(\mathrm{BH}_{4}\right)_{6} \\
\mathrm{Rb}_{3} \mathrm{Ce}\left(\mathrm{BH}_{4}\right)_{6} \\
\mathrm{Li}_{3} \mathrm{~K}_{3} \mathrm{Ce}_{2}\left(\mathrm{BH}_{4}\right)_{12}\end{array}$ & $\mathrm{NaPr}\left(\mathrm{BH}_{4}\right)_{4}$ & $\begin{array}{c}\mathbf{M S m}\left(\mathbf{B H}_{4}\right)_{3} \\
\mathrm{M}=\mathrm{K}, \mathrm{Rb}, \mathrm{Cs}\end{array}$ & $\begin{array}{c}\mathrm{NaEu}\left(\mathrm{BH}_{4}\right)_{4} \cdot 4 \mathrm{DME} \\
\mathrm{CsEu}\left(\mathrm{BH}_{4}\right)_{3} \\
\mathrm{RbEu}\left(\mathrm{BH}_{4}\right)_{3}\end{array}$ & $\begin{array}{c}\mathrm{NaGd}\left(\mathrm{BH}_{4}\right)_{4} \\
\mathrm{~A}_{\mathrm{n}} \mathbf{G d}\left(\mathrm{BH}_{4}\right)_{\mathrm{n}+3}, \mathrm{~A}=\mathrm{K}, \mathrm{Cs}\end{array}$ & $\mathrm{KHo}\left(\mathrm{BH}_{4}\right)_{4}$ & $\mathrm{NaEr}\left(\mathrm{BH}_{4}\right)_{4}$ & $\begin{array}{r}\mathrm{LiYb}\left(\mathrm{BH}_{4}\right)_{4} \\
\mathrm{NaYb}\left(\mathrm{BH}_{4}\right)_{4} \\
\mathrm{KYb}\left(\mathrm{BH}_{4}\right)_{4}\end{array}$ \\
\hline & & & & & & & & \\
\hline
\end{tabular}

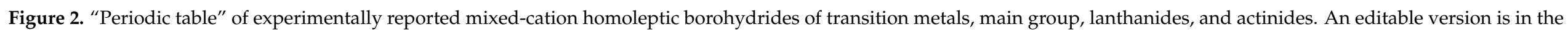
supplementary file. 
In the late 1970s, a timely and comprehensive review of transition metals, lanthanide, and actinide borohydride complexes was reported [21]. In 2015, an update which specialized in crystal chemistry was published [22]. Since 2017, an important review of borohydrides and derivates (including heteroleptic materials of the type $\mathrm{M}_{\mathrm{x}}\left(\mathrm{BH}_{4}\right)_{\mathrm{y}}\left(\mathrm{NH}_{2}\right)_{\mathrm{z}}$ and $\left.\mathrm{M}_{\mathrm{x}}\left(\mathrm{BH}_{4}\right)_{\mathrm{y}} \cdot \mathrm{nNH}_{3}\right)$ has been available for consultation [23]. In 2020, a highly informative paper on several hydrogen storage materials, including some borohydrides, was published [24]. In the last decade, research on the synthesis and characterization of bimetallic, trimetallic, anion-substituted (halide-substituted being more specific), and reactive composite mixtures of borohydrides has emerged, and it deserves a compilation. This work is a comprehensive review of the homoleptic borohydrides of transition metals, lanthanides, actinides, and main group block elements (Figures 1 and 2, editable versions of these figures are in the supplementary file), focusing on the hydrogen storage area, yet covering (when available) data for other applications. When considered necessary, halide-substituted borohydrides are also mentioned.

In the last sections, an overview of the thermodynamics (stability) of borohydrides is included. A section called "the boron problem" is included to discuss the contradictory problem of desirable low-temperature dehydrogenation and the release of $\mathrm{B}_{\mathrm{x}} \mathrm{H}_{\mathrm{y}}$ compounds.

\section{Synthesis}

Details of the synthesis are presented for each borohydride; however, in this short section, a recount of the generals of borohydrides' syntheses is presented. Synthesis methods can be divided roughly into two types: (i) "wet" synthesis methods in different organic solvents, and (ii) ball-milling synthesis. Wet synthesis has the advantages of better controlling the reaction conditions and products with higher purity, particularly with the new tendency of using mixtures of solvents or co-solvents during reactions and for product extraction. Some borohydrides have actually been produced only by this type of synthesis. Its drawbacks are the use of non-ecofriendly solvents and that some solvated materials are difficult to dry without them decomposing. For its part, ballmilling techniques produce impure borohydrides due to side reactions, by-products, and co-products (e.g., in the metathesis reactions). All these impurities may not always be inert during further reactions (i.e., during dehydrogenation reactions). The advantages of ball-milling are fast production, the possibility of scaling-up, and the chance to control temperature, pressure, and atmospheres during gas-solid reactions.

As additional types of synthesis method, we can include the "combined methods." Combined methods generally start with the pre-milling of raw materials, followed by their reaction in solvents and solvent extraction or, recently, the use of $\mathrm{S}\left(\mathrm{CH}_{3}\right)_{2} \cdot \mathrm{BH}_{3}$ as both a solvent and a reactant $[13,25]$. In all cases, precautions must be taken due to the materials' sensitivity to oxygen and moisture; handling, synthesis, storage, and characterization must be performed under protective atmospheres (argon, nitrogen, etc.) of high purity.

The general synthesis routes of homoleptic borohydrides can be classified as follows [23,26,27]:

1. Direct synthesis from elements. Usually, this kind of synthesis requires high pressure and temperature. Reducing particle size can (but not always) accelerate reaction kinetics. An example is the synthesis of $\mathrm{LiBH}_{4}$ from $\mathrm{Li}, \mathrm{B}$, and $\mathrm{H}_{2}$ at 150 bar and a temperature of $975 \mathrm{~K}$ [26].

2. Syntheses using $\mathrm{B}_{2} \mathrm{H}_{6}$ : For example, during wet synthesis, reagents such as $\mathrm{Mg}\left(\mathrm{CH}_{2} \mathrm{CH}_{3}\right)_{2}$ and $\mathrm{B}_{2} \mathrm{H}_{6}$ can react to produce the corresponding Mg-borohydride [28]. In solid-gastype reactions, a metal hydride and $\mathrm{B}_{2} \mathrm{H}_{6}$ can react during ball milling. Notice that $\mathrm{B}_{2} \mathrm{H}_{6}$ is a toxic and unstable gas.

3. Reactive composites of metals or metal hydrides and metal borides. This type of synthesis has been widely demonstrated for $\mathrm{Li}, \mathrm{Na}$, and $\mathrm{Ca}$-borohydrides. The metal borides serve as a B-source, enhancing the kinetics and reducing thermodynamic constraints. Importantly, this kind of synthesis has demonstrated some degree of reversibility, particularly if $\mathrm{MgH}_{2}$ and $\mathrm{MgB}_{2}$ are involved. 


$$
\begin{gathered}
2 \mathrm{MH}+\mathrm{MgB}_{2}+4 \mathrm{H}_{2} \rightarrow 2 \mathrm{MBH}_{4}+\mathrm{MgH}_{2} \text {, for } \mathrm{M}=\mathrm{Li}, \mathrm{Na} \\
\mathrm{CaH}_{2}+\mathrm{MgB}_{2}+4 \mathrm{H}_{2} \rightarrow \mathrm{Ca}\left(\mathrm{BH}_{4}\right)_{2}+\mathrm{MgH} \mathrm{H}_{2} \\
2 \mathrm{LiH}+\mathrm{AlB}_{2}+3 \mathrm{H}_{2} \rightarrow 2 \mathrm{LiBH}_{4}+\mathrm{Al}
\end{gathered}
$$

4. Metathesis. This type of reaction is the most widely used synthesis method for borohydrides beyond Groups I and II, both by wet chemistry and ball-mill assisted synthesis. Usually, $\mathrm{LiBH}_{4}$ or (to a minor extent) $\mathrm{NaBH}_{4}$ are the preferred reagents due to their commercial availability. However, considering hydrogen storage applications, this kind of synthesis is useful only if the new material has better dehydrogenation kinetics, low dehydrogenation temperature, or better reversibility than the original $\mathrm{LiBH}_{4}$ or $\mathrm{NaBH}_{4}$. This statement is made because, normally, the hydrogen content of the new borohydride decreases compared to $\mathrm{LiBH}_{4}$; thus, other advantages over $\mathrm{LiBH}_{4}$ must be necessarily obtained. Additionally, unless proper separation of other metathesis products is accomplished, a significant decrease of the full mixture's hydrogen content is unavoidable. The general reaction is:

$$
n \mathrm{MBH}_{4}+\mathrm{M}^{\prime} \mathrm{X}_{\mathrm{n}} \rightarrow \mathrm{M}^{\prime}\left(\mathrm{BH}_{4}\right)_{\mathrm{n}}+n \mathrm{MX}
$$

A recent variation of this method involves the use of bulky anions and cations in solvents such as toluene, $\mathrm{CH}_{2} \mathrm{Cl}_{2}$, or $\mathrm{CHCl}_{3}$. For example [29]:

$$
\begin{gathered}
\mathrm{ZnCl}_{2}+2 \mathrm{NaBH}_{4}+[\text { cat }] \mathrm{BH}_{4} \rightarrow[\text { cat }]\left[\mathrm{Zn}\left(\mathrm{BH}_{4}\right)_{3}\right]+2 \mathrm{NaCl} \\
\mathrm{M}[\mathrm{an}]+[\mathrm{cat}]\left[\mathrm{Zn}\left(\mathrm{BH}_{4}\right)_{3}\right] \rightarrow \mathrm{M}\left[\mathrm{Zn}\left(\mathrm{BH}_{4}\right)_{3}\right] \downarrow+[\text { cat }][\mathrm{an}]
\end{gathered}
$$

where $[\mathrm{cat}]=\left[\mathrm{Ph}_{4} \mathrm{P}\right]^{+}$or $\left[\mathrm{nBu}_{4} \mathrm{~N}\right]^{+} ;[\mathrm{an}]=\left[\mathrm{Al}\left\{\mathrm{OC}-\left(\mathrm{CF}_{3}\right)_{3}\right\}_{4}\right]^{-}$or $\left[\mathrm{B}\left\{3,5-\left(\mathrm{CF}_{3}\right)_{2} \mathrm{C}_{6} \mathrm{H}_{3}\right\}_{4}\right]^{-}$, $\mathrm{M}=\mathrm{Li}, \mathrm{Na}, \mathrm{K}$.

5. Metathesis-addition [23]. As described in the next sections, there is a relationship between metal electronegativity and dehydrogenation temperature [30]. Thus, in principle, the production of bimetallic and trimetallic borohydrides opens the way to tune the thermodynamics of dehydrogenation. For this purpose, the metathesisaddition reaction can be a useful tool.

$$
(x+n y) \mathrm{MBH}_{4}+y \mathrm{M}^{\prime} \mathrm{X}_{\mathrm{n}} \rightarrow \mathrm{M}_{\mathrm{x}} \mathrm{M}_{\mathrm{y}}^{\prime}\left(\mathrm{BH}_{4}\right)_{\mathrm{x}+\mathrm{ny}}+n y \mathrm{MX}
$$

6. Synthesis using metal hydrides and $\mathrm{S}\left(\mathrm{CH}_{3}\right)_{2} \cdot \mathrm{BH}_{3}$. This type of synthesis has evolved mainly for rare-earth $(\mathrm{RE})$ metal borohydrides $\left(\mathrm{RE}\left(\mathrm{BH}_{4}\right)_{\mathrm{x}}\right)$. The synthesis reaction is preceded by the formation or conditioning of the corresponding metal hydride by mechanical milling. The reaction itself is carried out for a long time (even days of stirring with moderate heating) in toluene. Co-solvents such as dimethyl sulfide (DMS) can be used $[13,17,31]$. This reaction can be described as a nucleophilic addition mechanism [17]. Finally, extraction of the solvating $\mathrm{S}\left(\mathrm{CH}_{3}\right)_{2}$ molecules is performed by careful drying $[13,31]$.

$$
\mathrm{REH}_{3}+3 \mathrm{~S}\left(\mathrm{CH}_{3}\right)_{2} \cdot \mathrm{BH}_{3} \rightarrow \mathrm{RE}\left(\mathrm{BH}_{4}\right)_{3} \mathrm{~S}\left(\mathrm{CH}_{3}\right)_{2}+2 \mathrm{~S}\left(\mathrm{CH}_{3}\right)_{2}
$$

Special care must be taken during the drying process of borohydrides prepared in THF or ether. Some materials are simply delicate. In others, such as transition metals and RE-borohydrides, the solvent molecules cannot be removed without decomposing the borohydride. The use of low-coordination ability solvents [32] might be an option [24].

\section{Bonding and Structure of Metal Borohydrides}

The bonding and structure details of each borohydride are given, when available, in each element subsection. In this section, general trends are commented on only in 
terms of tetrahydroborates complexes (only $\left[\mathrm{BH}_{4}\right]^{-1}$ as ligands), monometallic (i.e., no bimetallic or trimetallic) compounds, and without bridging between two different metal centers. All these exceptions reflect the richness of the chemistry of metal borohydrides. A significant difference in comparison to the alkaline and alkaline earth borohydrides must be mentioned: for metals in Groups I and II, the bonding between $\left[\mathrm{BH}_{4}\right]^{-1}$ and the metal ions is considered of an ionic nature [33]. This bonding type translates, as in any ionic compound, to highly stable materials, i.e., compounds with high dehydrogenation temperatures (Figure 1). In the transition metal borohydrides, the bonding spans from ionic to covalent coordination, which gives interesting properties of hapticity, H-mobility, $\mathrm{H}$-exchange within the $\left[\mathrm{BH}_{4}\right]^{-1}$ ligand or with other $\mathrm{H}$-containing ligands, and reduced thermal stabilities in general (Figures 1 and 2) [34-36]. The interaction of the $\left[\mathrm{BH}_{4}\right]^{-1}$ ion with the transition metals occurs through bridging $\mathrm{H}$ atoms; thus, the hapticity can be $\eta^{1}, \eta^{2}$, or $\eta^{3}$ (Figure 3). Due to the closeness of B atoms with the central metal in some $\eta^{3}$ compounds, even an $\eta^{4}$ interaction has been proposed [34]. The structures of the borohydride complexes around the metal center can have trigonal-planar, tetrahedral, square planar, trigonal-bipyramidal, or square-pyramidal octahedral geometry, especially if other ligands are present or if some $\mathrm{H}$ atoms of the $\left[\mathrm{BH}_{4}\right]^{-1}$ are considered as a ligand. $\eta^{1}-, \eta^{2-}$, or $\eta^{3}-\left[\mathrm{BH}_{4}\right]^{-1}$ ligands are considered as two-, four-, or six-electron donor ligands in the borohydride metal-ligand interactions; therefore, some compounds such as $\mathrm{M}\left(\mathrm{\eta}^{3}-\mathrm{BH}_{4}\right)_{4}$ $(\mathrm{M}=\mathrm{Zr}, \mathrm{Y}$ or Hf) do not "follow" the 18-electron rule [37]. However, the 18-electron count is still obtained when symmetry restrictions account for orbital interactions [34]. The formation of compounds that exceed 18-electrons preferentially produces ionic complexes [37]. Another point to consider is the mean distance between the metal center and the $B$ atoms: in general, for the three $\eta^{1}, \eta^{2}$, or $\eta^{3}$ interaction modes, metals on the right side of the periodic table show larger distances than those on the left [34]. Moreover, first-row transition metals form shorter distances than those of the third row [34]. The integration of ligands different from $\left[\mathrm{BH}_{4}\right]^{-1}$ can reduce hapticity, and change the symmetry and the ionic or covalent bond nature. Manipulation of all these factors may prove useful in the hydrogen storage area.

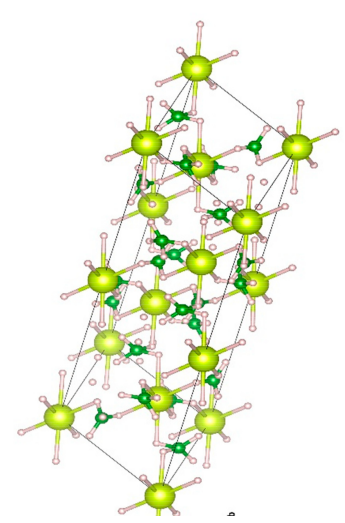

(a) $\eta^{1}$

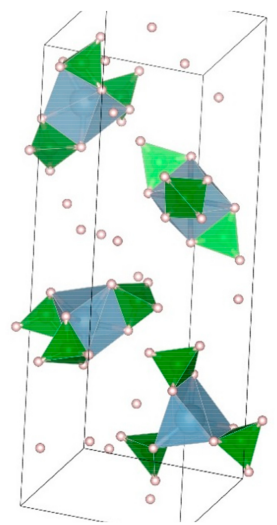

(b) $\eta^{2}$

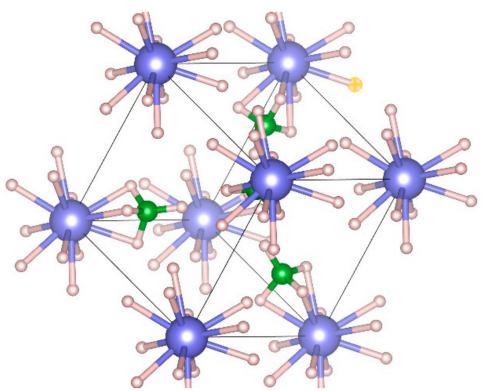

(c) $\eta^{3}$

Figure 3. Examples of $\eta^{1}, \eta^{2}$, and $\eta^{3}$ bonding between metals and $\left[\mathrm{BH}_{4}\right]^{-1}$ ions: (a) crystal structure of r-Ce $\left(\mathrm{BH}_{4}\right)_{3} ;(\mathbf{b})$ crystal structure of $\alpha-\mathrm{Al}\left(\mathrm{BH}_{4}\right)_{3} ;(\mathbf{c})$ crystal structure of $\mathrm{Zr}\left(\mathrm{BH}_{4}\right)_{3}$. Yellow balls-Ce, grey balls- $\mathrm{Al}$, purple balls $-\mathrm{Zr}$, green balls $-\mathrm{B}$, and light pink balls $-\mathrm{H}$.

Vibrational spectroscopy (infrared and Raman) is very useful for characterizing the structure of all borohydrides [38], i.e., for characterization of the coordination modes of borohydrides. Marks et al. resumed the observed bands in mononuclear borohydrides, as shown in Table 1 [21]: 
Table 1. Infrared and Raman bands typically observed in covalent metal-borohydrides [21].

\begin{tabular}{|c|c|}
\hline Coordination Modes of $\left[\mathrm{BH}_{4}\right]^{-1}$ & Frequency $\left[\mathrm{cm}^{-1}\right]$ and Type of Vibration \\
\hline$\eta^{1}$ & $\begin{array}{l}\text { 2300-2450: B-H(terminal) stretching } \\
\text { 2000: B-H(bridge) stretching } \\
\text { 2000-1700: } \mathrm{M}-\mathrm{H} \text { (bridge) stretching } \\
\text { 1000-1150: } \mathrm{BH}_{3} \text { deformation }\end{array}$ \\
\hline$\eta^{2}$ & $\begin{array}{l}\text { 2400-2600: B-H(terminal) stretching } \\
\text { 1650-2150: B-H(bridge) stretching } \\
\text { 1300-1500: Bridge stretching } \\
\text { 1100-1200: } \mathrm{BH}_{2} \text { deformation }\end{array}$ \\
\hline$\eta^{3}$ & $\begin{array}{l}\text { 2450-2600: B-H(terminal) stretching } \\
\text { 2100-2200: B-H(bridge) stretching } \\
\text { 1200-1250: Bridge deformation data }\end{array}$ \\
\hline
\end{tabular}

An excellent source (downloadable library) of IR-spectra of many borohydrides is the work of D'Anna et al. [39].

\section{Transition Metal Borohydrides}

\subsection{Group 3: Scandium and Yttrium}

In 2006, Nakamori et al. reported the formation of $\mathbf{S c}\left(\mathbf{B H}_{4}\right)_{3}$ in the solid-state by a metathesis reaction between $\mathrm{LiAlH}_{4}$ and $\mathrm{ScCl}_{3}$, activated by mechanical milling (5 h) [30]:

$$
3 \mathrm{LiBH}_{4}+\mathrm{ScCl}_{3} \rightarrow \mathrm{Sc}\left(\mathrm{BH}_{4}\right)_{3}+3 \mathrm{LiCl}
$$

The calculated structural parameters of $\mathrm{Sc}\left(\mathrm{BH}_{4}\right)_{3}$ are collected in Table 2 [30]. In the report by Nakamori, the onset and peak dehydrogenation temperatures of the mixture $3 \mathrm{LiBH}_{4}+\mathrm{ScCl}_{3}$ were $450 \mathrm{~K}$ and $550 \mathrm{~K}$ (as read approximately from a thermal desorption profile plot) [30]. The equivalent of Equation (9) in THF produced the mono-solvated material [40]. Further experiments indicated that the scandium borohydride reported in [30] was most probably $\mathbf{L i S c}\left(\mathbf{B H}_{4}\right)_{4}$, because no confirmation of the $\mathrm{Sc}\left(\mathrm{BH}_{4}\right)_{3}$ was reported. Data published in 2008 demonstrated that a change in the molar ratio of reaction Equation (9) produced $\mathrm{LiSc}\left(\mathrm{BH}_{4}\right)_{4}$ (Table 2) instead of $\mathrm{Sc}\left(\mathrm{BH}_{4}\right)_{3}$ [41,42]:

$$
4 \mathrm{LiBH}_{4}+\mathrm{ScCl}_{3} \rightarrow \mathrm{LiSc}\left(\mathrm{BH}_{4}\right)_{4}+3 \mathrm{LiCl}
$$

In $\mathrm{LiSc}\left(\mathrm{BH}_{4}\right)_{4}$, the scandium borohydride is, in fact, a complex ion: $\left[\mathrm{Sc}\left(\mathrm{BH}_{4}\right)_{4}\right]^{-1}$ (See Figure 4). The formation of complex borohydride ions is a characteristic shared with transition metal borohydrides, frequently facilitated by changes in the precursors' molar ratio.

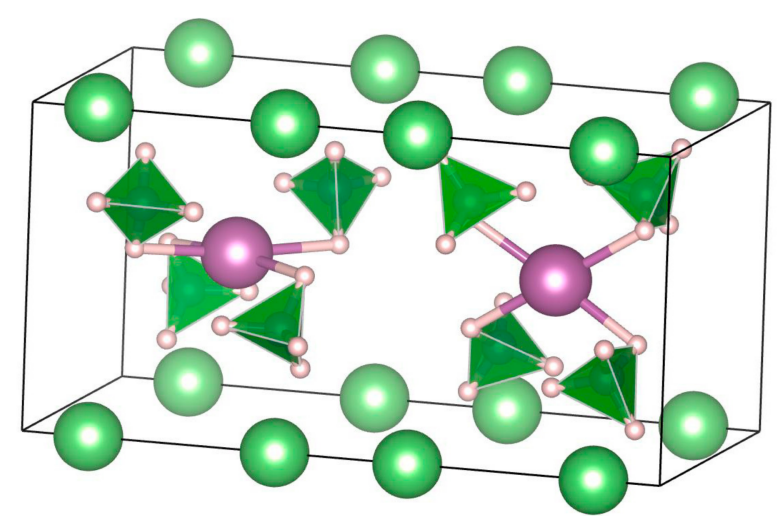

Figure 4. Crystal structure of $\mathrm{LiSc}\left(\mathrm{BH}_{4}\right)_{4}$, highlighting the $\left[\mathrm{Sc}\left(\mathrm{BH}_{4}\right)_{4}\right]^{-1}$ complex ion: $\left[\mathrm{BH}_{4}\right]^{-1}-$ green tetrahedra, $\mathrm{Sc}-$ pink ball, and Li-green ball. Detailed crystallographic information is available in Table 2. 
Černý et al. found a significant mass loss (decomposition) of $\mathrm{LiSc}\left(\mathrm{BH}_{4}\right)_{4}$ in a range between $415 \mathrm{~K}$ and $535 \mathrm{~K}$ [43]. Employing DFT modeling, Kim et al. confirmed the stability of $\mathrm{LiSc}\left(\mathrm{BH}_{4}\right)_{4}$ at room temperature [44]. They proposed a complex multistep dehydrogenation reaction in which $\mathrm{LiBH}_{4}, \mathrm{LiB}_{12} \mathrm{H}_{12}$, and $\mathrm{ScH}_{2}$ would act as intermediaries, while $\mathrm{LiH}, \mathrm{ScB}_{2}$, and $\mathrm{ScB}_{12}$ (in addition to $\mathrm{H}_{2}$ ) would be the final products [44]. Kim et al. confirmed the formation of $\mathrm{ScB}_{2}$ upon heating to $673 \mathrm{~K}$ and between 0.1 and $0.3 \mathrm{MPa}$ hydrogen pressure [44]. Re-hydrogenation at $673 \mathrm{~K}$ and $7 \mathrm{MPa} \mathrm{H}_{2}$ pressure increased the $\mathrm{Li}_{2} \mathrm{~B}_{12} \mathrm{H}_{12}$ content while forming a small amount of $\mathrm{LiBH}_{4}$ [44]. No more recent reports were found describing the dehydrogenation/rehydrogenation reactions of $\mathrm{LiSc}\left(\mathrm{BH}_{4}\right)_{4}$.

$\mathbf{N a S c}\left(\mathbf{B H}_{4}\right)_{4}$ and $\mathbf{K S c}\left(\mathbf{B H}_{4}\right)_{4}$ also have been produced, and their crystallographic properties characterized (Table 2). For the production of $\mathrm{NaSc}\left(\mathrm{BH}_{4}\right)_{4}$, Černý et al. tried different stoichiometric ratios between $\mathrm{NaBH}_{4}$ and $\mathrm{ScCl}_{3}$. Independently of the ratio, the synthetic reaction promoted by ball-milling was described as [43]:

$$
4 \mathrm{NaBH}_{4}+2 \mathrm{ScCl}_{3} \rightarrow \mathrm{NaSc}\left(\mathrm{BH}_{4}\right)_{4}+\mathrm{Na}_{3} \mathrm{ScCl}_{6}
$$

$\mathrm{NaBH}_{4}$ might be regenerated during the first dehydrogenation step of $\mathrm{NaSc}\left(\mathrm{BH}_{4}\right)_{4}$ $(440-490 \mathrm{~K})$ [43]. $\mathrm{Na}_{3} \mathrm{ScCl}_{6}$ participates in further dehydrogenation reactions. In the second step (495-540 K), $\mathrm{NaBH}_{4}$ (remanent from the synthesis and also formed during the first decomposition step) reacts with $\mathrm{Na}_{3} \mathrm{ScCl}_{6}$; a solid solution of $\mathrm{Na}\left(\mathrm{BH}_{4}\right)_{1-\mathrm{x}} \mathrm{Cl}_{\mathrm{x}}$ is proposed to be formed. $\mathrm{NaCl}$ and $\mathrm{ScB}_{\mathrm{x}}$ are among the final dehydrogenation products [43].

Several theoretical studies [45-48] followed the experimental report of Černý et al. [43]. Kim proposed, based on first-principle calculations, that the decomposition reaction would be $[47,48]$ :

$$
\mathrm{NaSc}\left(\mathrm{BH}_{4}\right)_{4} \rightarrow \mathrm{ScB}_{2}+3 / 4 \mathrm{NaBH}_{4}+1 / 8 \mathrm{Na}_{2} \mathrm{~B}_{10} \mathrm{H}_{10}+47 / 8 \mathrm{H}_{2}
$$

\begin{tabular}{|c|c|c|c|}
\hline $\begin{array}{l}\text { Material and } \\
\text { Hydrogen } \\
\text { Content [wt. } \% \text { ] }\end{array}$ & Structural Parameters $\left[\AA \AA^{\circ}\right]$ & Atomic Positions & Reference and Comments \\
\hline \multirow{2}{*}{$\begin{array}{l}\mathrm{Sc}\left(\mathrm{BH}_{4}\right)_{3} \\
\quad 13.51\end{array}$} & $\begin{array}{l}\text { Space group: trigonal } R-3(148) \\
\qquad \mathrm{a}=\mathrm{b}=7.262 ; \mathrm{c}=18.194 \\
\alpha=\beta=90 ; \gamma=120\end{array}$ & $\begin{array}{c}\text { Sc: } 0,0,0.3210 . \text { B: } 0.3503,0.3123,0.4079 . \text { H1: } \\
\text { 0.4002, 0.3671, 0.3423. H2: } 0.3691,0.4611,0.4432 . \\
\text { H3: } 0.1636,0.1647,0.4130 . \text { H4: } 0.4588,0.2370 \\
0.4329\end{array}$ & Theoretical calculation [30] \\
\hline & $\begin{array}{l}\text { Space group: orthorhombic } C 222_{1} \\
\qquad \begin{array}{c}(20) \\
a=8.34, b=11.94 ; c=7.90 \\
\alpha=\beta=\gamma=90\end{array}\end{array}$ & $\begin{array}{c}\text { Sc: } 0.1882,0,0 . \text { B1: } 0.3254,0.1593,0.9642 . \text { B2: } 0.5 \\
0.4978,0.25 \text {. H1: } 0.4045,0.2411,0.9457 . \text { H2: } 0.3191 \\
0.0983,0.8355 . \text { H3: } 0.3770,0.0950,0.0770 . \text { H4: } \\
0.1854,0.1775,0.0036 . \text { H5: } 0.1167,0.0597,0.2407 \\
\text { H6: } 0.5192,0.4369,0.3732\end{array}$ & Theoretical calculation [44] \\
\hline \multirow{2}{*}{$\begin{array}{l}\mathrm{LiSc}\left(\mathrm{BH}_{4}\right)_{4} \\
14.49\end{array}$} & $\begin{array}{l}\text { Space group: tetragonal } P-42 c \\
(112) \\
\begin{array}{c}a=b=6.0759(1) ; c=12.0338(1) \\
\alpha=\beta=\gamma=90\end{array}\end{array}$ & $\begin{array}{c}\text { Li: } 0,0,0.104(2) \text { Sc: } 0.5,0.5,0.25 . \mathrm{B}: 0.75,0.6722(6), \\
0.6386(3) . \text { H1: } 0.7939,0.6688,0.7251 . \\
\text { H2: } 0.8960,0.6926,0.5891 . \text { H3: } 0.6394,0.8072 \\
\text { 0.6234. H4: } 0.6705,0.5201,0.6166\end{array}$ & $\begin{array}{l}\text { Refinement of high-resolution } \\
\text { synchrotron powder diffraction } \\
\text { and comparison to DFT } \\
\text { calculations [42] }\end{array}$ \\
\hline & $\begin{array}{l}\text { Space group: tetragonal } I-4 \text { (82) } \\
\qquad \begin{array}{c}\mathrm{a}=\mathrm{b}=6.479 ; \mathrm{c}=12.043 \\
\alpha=\beta=\gamma=90\end{array}\end{array}$ & $\begin{array}{c}\text { Li: } 0,0.5,0.25 \text {. Sc: } 0,0,0.5 \text {. B: } 0.3534,0.2469,0.8889 . \\
\text { H1: 0.7621, } 0.6206,0.3339 \text {. H2: } 0.5416,0.2551 \\
\text { 0.8711. H3: } 0.2852,0.4221,0.8705 . \text { H4: } 0.3325 \\
0.2111,0.9890\end{array}$ & Theoretical calculation [44] \\
\hline \multirow{2}{*}{$\begin{array}{l}\mathrm{NaSc}_{(}\left(\mathrm{BH}_{4}\right)_{4} \\
12.67\end{array}$} & $\begin{array}{l}\text { Space group: orthorhombic Cmcm } \\
\qquad \begin{array}{c}(63) \\
a=8.170(2), b=11.875(3), c= \\
9.018(2) . \\
\alpha=\beta=\gamma=90\end{array}\end{array}$ & $\begin{array}{c}\text { Na: } 0,0,0.5 \text {. Sc: } 0.5,0.1462(7), 0.75 \text {. B1: } 0.5 \\
0.255(1), 0.957(2) . \text { H11: } 0.5,0.309(1), 1.060(2) . \text { H12: } \\
\text { 0.5, 0.163(1), 0.989(2). H13: } 0.613(2), 0.274(1) \\
0.889(2) . \text { B2: } 0.724(2), 0.036(1), 0.75 \text { H21: } 0.837(2) \\
-0.020(1), 0.75 . \text { H22: } 0.762(2), 0.127(1), 0.75 . \text { H23: } \\
\text { 0.649(2), } 0.017(1), 0.852(2)\end{array}$ & $\begin{array}{l}\text { Experimental synchrotron } \\
\text { powder diffraction [43] }\end{array}$ \\
\hline & $\begin{array}{l}\text { Space group: orthorhombic } C 222_{1} \\
\qquad \begin{array}{c}(20) \\
a=8.318, b=11.827, c=9.117 \\
\alpha=\beta=\gamma=90\end{array}\end{array}$ & $\begin{array}{c}\text { Na: } 0.07322,0,0 . \text { Sc: } 0,0.34577,0.25 . \text { B1: }-0.49941, \\
0.26614,-0.4569 . \text { B2: } 0.27125,0.04152,-0.25031 . \\
\text { H1: }-0: 49327,0.32151,0.43233 . \text { H2: } 0.39351, \\
0.29602,-0.37049 . \text { H3: } 0: 12897,0.23042,0.38793 . \\
\text { H4: }-0.35012,0.48568,-0.25753 . \text { H5: } 0.24323, \\
0.14288,-0.27103 . \text { H6: } 0.3702,0.01058,-0.34298 . \\
\text { H7: } 0.16075,0.46621,0.3703 . \text { H8: } 0.47365,0.16592, \\
-0.4863\end{array}$ & Theoretical calculation [45] \\
\hline
\end{tabular}

Table 2. Crystal structures of Sc-borohydrides. 
Table 2. Cont.

\begin{tabular}{|c|c|c|c|}
\hline $\begin{array}{c}\text { Material and } \\
\text { Hydrogen } \\
\text { Content [wt. } \%]\end{array}$ & Structural Parameters $\left[\AA \AA^{\circ}\right]$ & Atomic Positions & Reference and Comments \\
\hline $\begin{array}{c}\mathrm{KSc}\left(\mathrm{BH}_{4}\right)_{4} \\
11.24\end{array}$ & $\begin{array}{l}\text { Space group: orthorhombic Pnma } \\
\qquad \begin{array}{c}(62) \\
\mathrm{a}=11.8558(47), \mathrm{b}=7.7998(34) ; \mathrm{c}= \\
10.1258(63) \\
\alpha=\beta=\gamma=90\end{array}\end{array}$ & $\begin{array}{c}\text { K: } 0.1947(16), 0.25,0.6527(17) . \text { Sc: } 0.0640(16), 0.25 \\
\text { 0.2152(15). B1: } 0.1647(32), 0.25,0.0150(23) . \text { H11: } \\
0.2342(48), 0.25,0.0939(74) \text { H12: } 0.2050(75), 0.25 \\
\text {-0.0881(39). H13: } 0.1097(33), 0.37018(21) \\
\text { 0.0271(41). B2: } 0.3819(21), 0.25,0.3840(45) . \text { H21: } \\
0.3790(37), 0.25,0.2706(45) . \text { H22: } 0.2917(28), 0.25 \\
0.4251(69) . \text { H23: } 0.4286(26), 0.37018(21), 0.4201(43) \\
\text { B3: } 0.0901(15), 0.0137(21), 0.3431(18) . \text { H31: } \\
0.080(13),-0.1071(38), 0.4069(53) . \text { H32: } 0.058(12) \\
-0.0137(51), 0.2383(28) . \text { H33: } 0.183(10), 0.052(18) \\
0.339(10) . \text { H34: } 0.0386(90), 0.124(22), 0.3886(94)\end{array}$ & Experimental data [49] \\
\hline $\begin{array}{c}\mathrm{RbSc}_{\left(\mathrm{BH}_{4}\right)_{4}} \\
8.50\end{array}$ & $\begin{array}{c}\text { Space group: orthorhombic Pbcm } \\
\text { (57) } \\
\begin{array}{c}\mathrm{a}=7.6514, \mathrm{~b}=11.1821, \mathrm{c}=11.2443 \\
\alpha=\beta=\gamma=90\end{array}\end{array}$ & 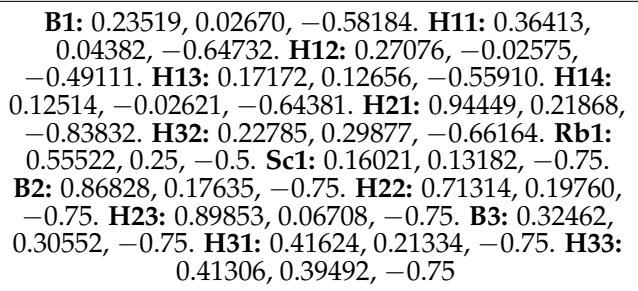 & Computationally optimized [50] \\
\hline $\begin{array}{c}\mathrm{CsSc}\left(\mathrm{BH}_{4}\right)_{4} \\
6.80\end{array}$ & $\begin{array}{c}\text { Space group: monoclinic } P 2{ }_{1} / c 14 \\
\mathrm{a}=9.5870, \mathrm{~b}=10.7270, \mathrm{c}=12.2280 \\
\alpha=90, \beta=126.3510, \gamma=90\end{array}$ & 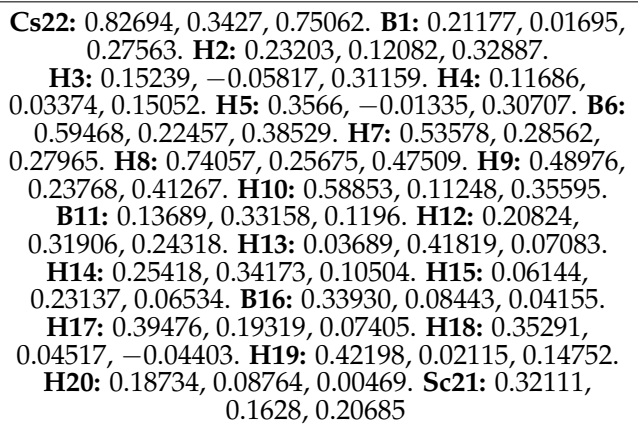 & Computationally optimized [50] \\
\hline
\end{tabular}

Alternative structures and dehydrogenation reactions of (12) have been reported; for example, H. D. Tran et al. reported that $\mathrm{NaSc}\left(\mathrm{BH}_{4}\right)_{4}$ with an orthorhombic $\mathrm{C} 222_{1}$ structure [45] would be more stable than the orthorhombic $\mathrm{Cmcm}$ structure reported by Černý et al. (Table 2) [43]. The formation enthalpy of orthorhombic $\mathrm{Cmcm} \mathrm{NaSc}\left(\mathrm{BH}_{4}\right)_{4}$ was independently calculated as $-72.69 \mathrm{~kJ} / \mathrm{mol} \mathrm{H}_{2}$ [46]. The theoretical calculations for $\mathrm{NaSc}\left(\mathrm{BH}_{4}\right)_{4}$ indicated an electrical insulator with a band gap of $5.055 \mathrm{eV} \mathrm{[48].}$

$\mathbf{K S c}\left(\mathbf{B H}_{4}\right)_{4}$ was reported in 2010; this material presents similarities with $\mathrm{NaSc}\left(\mathrm{BH}_{4}\right)_{4}$ but not with $\mathrm{LiSc}\left(\mathrm{BH}_{4}\right)_{4}$ [49]. The synthesis reaction promoted by ball-milling was:

$$
4 \mathrm{KBH}_{4}+2 \mathrm{ScCl}_{3} \rightarrow \mathrm{KSc}\left(\mathrm{BH}_{4}\right)_{4}+\mathrm{K}_{3} \mathrm{ScCl}_{6}
$$

Several stoichiometric ratios between $\mathrm{KBH}_{4}$ and $\mathrm{SCl}_{3}$ were tested; the best ratio was 2:1 [49]. $\mathrm{KSc}\left(\mathrm{BH}_{4}\right)_{4}$ melts at $\sim 405 \mathrm{~K}$. The decomposition of $\mathrm{KSc}\left(\mathrm{BH}_{4}\right)_{4}$ at $460-500 \mathrm{~K}$ increases the amount of $\mathrm{KBH}_{4}$ (additional to that not reacted during synthesis) [49]. The second step

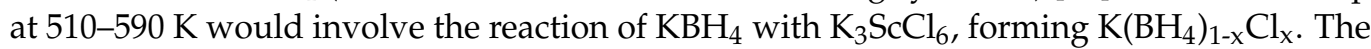
crystal structure was determined and is reported in Table 2 [49]. No further experimental reports were found on $\mathrm{KSc}\left(\mathrm{BH}_{4}\right)_{4}$.

$\mathrm{RbSc}\left(\mathrm{BH}_{4}\right)_{4}$ and $\mathrm{CsSc}\left(\mathrm{BH}_{4}\right)_{4}$ were recently reported [50]. Both materials were produced by mechanical milling and solvent metathesis; thus, a direct comparison of the effects of the co-metathesis product was made. The synthesis reactions are [50]:

$$
\begin{gathered}
\mathrm{ScCl}_{3}+3 \mathrm{MBH}_{4} \rightarrow 0.5 \mathrm{MSc}\left(\mathrm{BH}_{4}\right)_{4}+\mathrm{MBH}_{4}+0.5 \mathrm{M}_{3} \mathrm{ScCl}_{6} \\
\mathrm{ScCl}_{3}+2 \mathrm{MBH}_{4} \rightarrow 0.5 \mathrm{MSc}\left(\mathrm{BH}_{4}\right)_{4}+0.5 \mathrm{M}_{3} \mathrm{ScCl}_{6} \\
\mathrm{ScCl}_{3}+\mathrm{MBH}_{4}+3 \mathrm{LiBH}_{4} \rightarrow \mathrm{MSc}\left(\mathrm{BH}_{4}\right)_{4}+3 \mathrm{LiCl}
\end{gathered}
$$


where $\mathrm{M}=\mathrm{Rb}$, Cs. Pure borohydrides were extracted with dimethyl sulfide (DMS). $\mathrm{RbSc}\left(\mathrm{BH}_{4}\right)_{4}$ presents an orthorhombic $\mathrm{Pbcm}$ space group, while $\mathrm{CsSc}\left(\mathrm{BH}_{4}\right)_{4}$ is monoclinic $P 2_{1} / c$ (Table 2) [50]. Starobrat et al. reported that, in $\mathrm{RbSc}\left(\mathrm{BH}_{4}\right)_{4}$, the $\mathrm{Rb}^{+}$and $\left[\mathrm{Sc}\left(\mathrm{BH}_{4}\right)_{4}\right]^{-1}$ ions create zig-zag lines of alternate ions along the c-axis [50]. Meanwhile, in $\mathrm{CsSc}\left(\mathrm{BH}_{4}\right)_{4}$, $\mathrm{Cs}^{+}$and $\left[\mathrm{Sc}\left(\mathrm{BH}_{4}\right)_{4}\right]^{-1}$ have three counterions as nearest neighbors [50]. Decomposition of pure and $\mathrm{LiCl}$-mixed $\mathrm{RbSc}\left(\mathrm{BH}_{4}\right)_{4}$ is preceded by an endothermic event at $432 \mathrm{~K}$, associated with a melting or phase transition. The main decomposition step was located at $510 \mathrm{~K}$ and was described as mainly endothermic but with an exothermic shoulder [50].

Decomposition of pure $\operatorname{RbSc}\left(\mathrm{BH}_{4}\right)_{4}$ was described as [50]:

$$
\mathrm{RbSc}\left(\mathrm{BH}_{4}\right)_{4} \rightarrow \mathrm{RbBH}_{4}+6 \mathrm{H}_{2}+\mathrm{B}+\mathrm{ScB}_{2}
$$

However, a minor reaction associated with the diborane evolution was described as:

$$
\mathrm{RbSc}\left(\mathrm{BH}_{4}\right)_{4} \rightarrow \mathrm{RbBH}_{4}+9 / 2 \mathrm{H}_{2}+1 / 2 \mathrm{~B}_{2} \mathrm{H}_{6}+\mathrm{ScB}_{2}
$$

In the sample containing $\mathrm{LiCl}$, a third endothermic event at $559 \mathrm{~K}$ was reported. Finally, $\mathrm{RbBH}_{4}$ decomposed above $773 \mathrm{~K}$ [50].

$\mathrm{CsSc}\left(\mathrm{BH}_{4}\right)_{4}$ decomposition presents a melting or phase transition event at $480 \mathrm{~K}$, a hydrogen release at $511 \mathrm{~K}$, with minor $\mathrm{B}_{2} \mathrm{H}_{6}$ production (equations analogous to (17) and (18)), and probable formation of a ternary chloride at $532 \mathrm{~K}$ [50]:

$$
\mathrm{CsSc}\left(\mathrm{BH}_{4}\right)_{4}+3 \mathrm{LiCl} \rightarrow \mathrm{CsLi}_{2} \mathrm{Cl}_{3}+15 / 2 \mathrm{H}_{2}+\mathrm{ScB}_{\mathrm{x}}+(4-x) \mathrm{B}+\mathrm{LiH}
$$

$\mathrm{CsBH}_{4}$ decomposition into $\mathrm{Cs}, \mathrm{B}$, and $\mathrm{H}_{2}$ was observed at $695 \mathrm{~K}$ [50].

The first reports on yttrium borohydrides date to the 1960s. Back then, the compound was obtained as a THF abduct: $\mathrm{Y}\left(\mathrm{BH}_{4}\right)_{3}(\mathrm{THF})_{3}[51,52]$ (and references therein). The usual reactants were $\mathrm{YCl}_{3}$ and $\mathrm{LiBH}_{4}$ in THF, but the reaction between $\mathrm{Y}\left(\mathrm{OCH}_{3}\right)_{3}$ with $\mathrm{B}_{2} \mathrm{H}_{6}$ in THF was also reported [51]. Later, in 2008, the metathesis synthesis of $Y\left(\mathrm{BH}_{4}\right)_{3}$ was performed; it was assisted by ball-milling [53]:

$$
\mathrm{YCl}_{3}+3 \mathrm{LiBH}_{4} \rightarrow \mathrm{Y}\left(\mathrm{BH}_{4}\right)_{3}+3 \mathrm{LiCl}
$$

Alternatively, to avoid the formation of $\mathrm{LiCl}, \mathrm{Y}\left(\mathrm{BH}_{4}\right)_{3}$ can be produced by a gas-solid reaction promoted by mechanical milling $[54,55]$ :

$$
\mathrm{YH}_{3}+3 / 2 \mathrm{~B}_{2} \mathrm{H}_{6} \rightarrow \mathrm{Y}\left(\mathrm{BH}_{4}\right)_{3}
$$

$\mathrm{Y}\left(\mathrm{BH}_{4}\right)_{3}$ crystallizes in a cubic structure, $\mathrm{Pa}-3$ (205) (low-temperature $\alpha$-phase, Table 3); theoretical calculations give a formation enthalpy of $-113 \mathrm{~kJ} / \mathrm{mol} \mathrm{BH}_{4}$ and predict $\mathrm{Y}\left(\mathrm{BH}_{4}\right)_{3}$ to be an insulator [53]. $\mathrm{Y}\left(\mathrm{BH}_{4}\right)_{3}(+3 \mathrm{LiCl})$ has a solid $(\alpha$ to $\beta)$ phase transition, the transition temperature was reported as $483 \mathrm{~K}$ [56] or $453 \mathrm{~K}[54,57]$. In the high-temperature polymorph, the structure is cubic $F m-3 c$ (226); the $\left[\mathrm{BH}_{4}\right]^{-1}$ ion is distorted from an ideal tetrahedron [58] and it can be considered an $\eta^{2}$ type interaction with $\mathrm{Y}^{+3}$. However, Park et al. [55] and Remhof et al. [54] did not observe the $\alpha$ to $\beta$ phase transition in $\mathrm{Y}\left(\mathrm{BH}_{4}\right)_{3}$ (from reaction (21)), i.e., without $\mathrm{LiCl}$ ).

Dehydrogenation reactions have been described in several papers. In these published results stands out the multistep nature of the dehydrogenation reaction and some differences between the dehydrogenation pathway of pure $\mathrm{Y}\left(\mathrm{BH}_{4}\right)_{3}$ and $\mathrm{Y}\left(\mathrm{BH}_{4}\right)_{3}+3 \mathrm{LiCl}$ (i.e., upon the synthesis method and purification). The decomposition of $\left.\mathrm{Y}_{(\mathrm{BH}}\right)_{3}+3 \mathrm{LiCl}$ proposed by Jaron et al. starts at $423-433 \mathrm{~K}$ with a small mass release (explained in that work as a probable melting phase transition), a second step at 533-678 K, and the last stage of dehydrogenation that starts above $698 \mathrm{~K}$ [56]. By its part, the dehydrogenation mechanism proposed by Ranvsbæk et al. first involved the $\mathrm{Y}\left(\mathrm{BH}_{4}\right)_{3}$ solid $\alpha$ to $\beta$ phase transition, followed by the $\beta-Y\left(\mathrm{BH}_{4}\right)_{3}$ decomposition, starting at $463 \mathrm{~K}$ and forming $\mathrm{YH}_{3}$, which then produced $\mathrm{YH}_{2}$ at $543 \mathrm{~K}$ [57]. The dehydrogenation mechanism also involved the evolution 
of an unidentified compound between 488 and $553 \mathrm{~K}$ and $\mathrm{YB}_{4}$ as a final decomposition product [57]. The occurrence of an unidentified peak during synchrotron radiation powder X-ray diffraction (SR-PXD) characterization was also observed by Frommen et al. between 473 and $520 \mathrm{~K}$ for a mixture of $\mathrm{Y}\left(\mathrm{BH}_{4}\right)_{3}+3 \mathrm{LiCl}$ prepared by cryogenic ball milling [58]. Yan et al. proposed $\mathrm{Y}\left(\mathrm{B}_{3} \mathrm{H}_{8}\right)_{3}$ as the dehydrogenation intermediary's possible identity [59].

Remhof et al. [54] and Park et al. [55] observed different decomposition pathways of $\mathrm{Y}\left(\mathrm{BH}_{4}\right)_{3}$ without $\mathrm{LiCl}$. $\mathrm{Y}\left(\mathrm{BH}_{4}\right)_{3}$ (from Equation (21)) started decomposing at $460 \mathrm{~K}$, with a maximum rate at $523 \mathrm{~K}$. No indications of solid $\alpha$ to $\beta$ phase transformation were found, but positive indications of melting right before decomposition were revealed by time-resolved in-situ XRD [54]. Park et al. proposed that LiCl slightly shifts the peaktemperature decomposition of $\mathrm{Y}\left(\mathrm{BH}_{4}\right)_{3}$ and promotes the formation of $\mathrm{YB}_{4}$ [55]. The decomposition products reported by Park et al. were $\mathrm{YH}_{2}, \mathrm{YB}_{4}, \mathrm{Y}$, and $\mathrm{Y}_{2} \mathrm{O}_{3}$.

The decomposition pathway observed by Yan et al. in pure $\mathrm{Y}\left(\mathrm{BH}_{4}\right)_{3}$ (obtained by reaction (21) in ether, followed by precipitation and drying) comprises (a) phase transition,

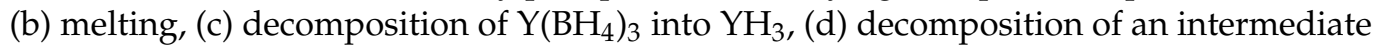
phase, and (e) decomposition of $\mathrm{YH}_{3}$ into $\mathrm{YH}_{2}$ [60]. This pathway is more similar to the $\mathrm{Y}\left(\mathrm{BH}_{4}\right)_{3}+3 \mathrm{LiCl}$ dehydrogenation studies reviewed above.

Lee et al., utilizing theoretical calculations, proposed a series of dehydrogenation reactions, where the products are a combination of $\mathrm{YH}_{3}, \mathrm{YH}_{2}, \mathrm{YB}_{4}, \mathrm{YB}_{6}, \mathrm{~B}, \mathrm{Y}$, and $\mathrm{H}_{2}$ [61]. Given the experimental reaction products commented above, a possible first-step dehydrogenation reaction could be:

$$
\beta-\mathrm{Y}\left(\mathrm{BH}_{4}\right)_{3} \rightarrow \frac{1}{4} \mathrm{YH}_{3}+\frac{3}{4} \mathrm{YB}_{4}+45 / 8 \mathrm{H}_{2}
$$

The calculated dehydrogenation temperature of (22) at $\mathrm{P}_{\mathrm{H} 2}=0.1 \mathrm{MPa}$ is $\sim 195 \mathrm{~K}$, $\Delta \mathrm{H}^{0}=22.5 \mathrm{~kJ} / \mathrm{mol} \mathrm{H}_{2}$ [61].

Another point to mention is the release of B-H compounds. The results are not unanimous; some reports indicate no release while others indicate the evolution of boron hydrides. On the other hand, the reported formation of $\mathrm{YB}_{4}$ [55] is good in terms of a possible rehydrogenation. Partial rehydrogenation was achieved at $35 \mathrm{MPa}$ at $523 \mathrm{~K}$ and $573 \mathrm{~K}[60]$.

$\mathrm{LiY}\left(\mathrm{BH}_{4}\right)_{4}$ and $\mathrm{NaY}\left(\mathrm{BH}_{4}\right)_{4}$ were obtained by ball-milling of $\mathrm{Li}, \mathrm{Na}$, and $\mathrm{Y}$-borohydrides, heating at $473 \mathrm{~K}$ and $453 \mathrm{~K}$ for the $\mathrm{LiY}\left(\mathrm{BH}_{4}\right)_{4}$ and $\mathrm{NaY}\left(\mathrm{BH}_{4}\right)_{4}$, respectively, and then quenching [62]. Another option is the use of weakly coordinating anions in weakly coordinating solvents such as $\mathrm{CH}_{2} \mathrm{Cl}_{2}$, i.e., equivalent to reactions (5) and (6) [63]. $\mathrm{LiY}\left(\mathrm{BH}_{4}\right)_{4}$ and $\mathrm{NaY}\left(\mathrm{BH}_{4}\right)_{4}$ are isostructural with the tetragonal $P-42 \mathrm{c} \mathrm{LiSc}\left(\mathrm{BH}_{4}\right)_{4}$, and orthorhombic $\mathrm{C} 222{ }_{1} \mathrm{NaSc}\left(\mathrm{BH}_{4}\right)_{4}$ (Table 3) [62]. Their values of ionic conductivities are $1.26 \times 10^{-6}$ and $6.92 \times 10^{-7} \mathrm{~S} \mathrm{~cm}^{-1}$ at room temperature, $\mathrm{LiY}\left(\mathrm{BH}_{4}\right)_{4}$ and $\mathrm{NaY}\left(\mathrm{BH}_{4}\right)_{4}$, respectively [62]. Dai et al., employing first-principles calculations, indicated that the formation of $\mathrm{KY}\left(\mathrm{BH}_{4}\right)_{4}$ is thermodynamically feasible; meanwhile, the formation of analogous materials with $\mathrm{Li}$ and $\mathrm{Na}$ is not possible [64]. $\mathrm{LiY}\left(\mathrm{BH}_{4}\right)_{4}$ and $\mathrm{NaY}\left(\mathrm{BH}_{4}\right)_{4}$ are, in fact, metastable materials that decompose during days or weeks at room temperature or upon heating to $402 \mathrm{~K}$ or $388 \mathrm{~K}$, respectively [62].

$\mathbf{K Y}\left(\mathbf{B H}_{4}\right)_{4}$ was produced by the reaction between $\mathrm{Y}\left(\mathrm{BH}_{4}\right)_{3}$ (produced by reaction (20)) in a previous step, without elimination of $\mathrm{LiCl}$ ) and $\mathrm{KBH}_{4}$ [65]:

$$
\mathrm{Y}\left(\mathrm{BH}_{4}\right)_{3}+\mathrm{KBH}_{4} \rightarrow \mathrm{KY}\left(\mathrm{BH}_{4}\right)_{4}
$$

Reaction (23) was promoted by mechanical milling under a careful regime of alternating periods of 3 min milling/2-3 min resting. $\mathrm{KY}\left(\mathrm{BH}_{4}\right)_{4}$ is isostructural with $\mathrm{NaY}\left(\mathrm{BH}_{4}\right)_{4}$ (Table 3), and forms a complex anion $\left.\left[\mathrm{Y}_{(\mathrm{BH}}\right)_{4}\right]^{-1}$ of a slightly distorted tetrahedral geometry [65]. Furthermore, $\left[\mathrm{BH}_{4}\right]^{-1}$ ions have $\eta^{3}$ interactions with $\mathrm{Y}$ [65]. The dehydrogenation of $\mathrm{KY}\left(\mathrm{BH}_{4}\right)_{4}$ is also a multistep process: (a) the first step is melting at $453 \mathrm{~K}$; (b) from $463-483 \mathrm{~K}$, an unidentified phase is detected; (c) the presence of $\mathrm{KBH}_{4}$ is confirmed and increases upon heating at higher temperatures (493 K); (d) a probable decomposition of 
$\mathrm{YH}_{3}$ into $\mathrm{YH}_{2}$ occurs at $543 \mathrm{~K}$; and (e) two more TGA/DCS peaks are detected at $611 \mathrm{~K}$ and $632 \mathrm{~K}[65]$.

The mixture of $\mathrm{NaBH}_{4}$ and $\mathrm{Y}\left(\mathrm{BH}_{4}\right)_{3}$ (with $\mathrm{LiCl}$ ) produced $\mathrm{NaY}\left(\mathrm{BH}_{4}\right)_{2} \mathrm{Cl}_{2}$ upon heating at $438 \mathrm{~K}$ [65]. One year later, in 2012, a detailed study of $\mathrm{NaY}\left(\mathrm{BH}_{4}\right)_{2} \mathrm{Cl}_{2}$ was published [66]. The synthesis reaction promoted by mechanical milling is [66]:

$$
2 \mathrm{NaBH}_{4}+\mathrm{YCl}_{3} \rightarrow \mathrm{NaY}\left(\mathrm{BH}_{4}\right)_{2} \mathrm{Cl}_{2}+\mathrm{NaCl}
$$

However, side reactions produced $\mathrm{Na}_{2} \mathrm{YCl}_{6}$ and $\mathrm{Na}\left(\mathrm{BH}_{4}\right)_{1-\mathrm{x}} \mathrm{Cl}$. $\mathrm{NaY}\left(\mathrm{BH}_{4}\right)_{2} \mathrm{Cl}_{2}$ crystallizes in the monoclinic $P 2 / c$ space group symmetry. DFT optimization of the geometry indicates that the $\left[\mathrm{BH}_{4}\right]^{-1}$ ions interacted via $\eta^{3}$ with $\mathrm{Y}$ and $\eta^{1}$ with $\mathrm{Na}$. $\mathrm{NaY}\left(\mathrm{BH}_{4}\right)_{2} \mathrm{Cl}_{2}$ decomposed at $\sim 573 \mathrm{~K}$ without a significant release of borane gases [66].

Binary Y-borohydrides $\mathbf{R b Y}\left(\mathbf{B H}_{4}\right)_{4}, \mathbf{C s Y}\left(\mathbf{B H}_{4}\right)_{4}, \mathbf{R b}_{3} \mathbf{Y}\left(\mathbf{B H}_{4}\right)_{6}$, and $\mathrm{Cs}_{3} \mathbf{Y}\left(\mathbf{B H}_{4}\right)_{6}$, and the ternary materials $\mathbf{R b}_{2} \mathbf{L i Y}\left(\mathbf{B H}_{4}\right)_{6}$ and $\mathbf{C s}_{2} \mathbf{L i Y}\left(\mathbf{B H}_{4}\right)_{6}$, were reported recently (Table 3) [67-69]. $\mathrm{RbY}\left(\mathrm{BH}_{4}\right)_{4}$ and $\mathrm{CsY}\left(\mathrm{BH}_{4}\right)_{4}$ were produced by mechanical milling of $\mathrm{Y}\left(\mathrm{BH}_{4}\right)_{3}$ and the corresponding $\mathrm{Rb}$ or Cs-borohydride [67]. However, the $\mathrm{Y}\left(\mathrm{BH}_{4}\right)_{3}$ was not purified and contained $\mathrm{LiCl}$. Thus, the ball-milled powders were a mixture of the bimetallic borohydrides, $\mathrm{Cl}$-substituted borohydrides (in Cs materials), and LiCl. Diffraction analysis resulted in a monoclinic $P 2_{1} / c \mathrm{RbY}\left(\mathrm{BH}_{4}\right)_{4}$, but the $\mathrm{Y}$ - $\mathrm{Rb}$ sublattice can be symmetrized to orthorhombic Pnma. The CsY $\left(\mathrm{BH}_{4}\right)_{4}$ structure was refined as a I4 $1 / a$ space group [67]. Decompositions of $\mathrm{RbY}\left(\mathrm{BH}_{4}\right)_{4}$ and $\mathrm{CsY}\left(\mathrm{BH}_{4}\right)_{4}$ were multistep processes that involved the formation of Cl-substituted bimetallic borohydrides: $\mathrm{Rb}_{2} \mathrm{Li}\left[\mathrm{Y}\left(\mathrm{BH}_{4}\right)_{6-\mathrm{x}} \mathrm{Cl}_{\mathrm{x}}\right]$ and $\mathrm{Cs}_{2} \mathrm{Li}\left[\mathrm{Y}\left(\mathrm{BH}_{4}\right)_{6-\mathrm{x}} \mathrm{Cl}_{\mathrm{x}}\right]$, i.e., the $\mathrm{LiCl}$ was not inert. The quickest decomposition step of $\mathrm{RbY}\left(\mathrm{BH}_{4}\right)_{4} / \mathrm{LiCl}$ occurred at $544 \mathrm{~K}$, and above $523 \mathrm{~K}$ for $\mathrm{CsY}\left(\mathrm{BH}_{4}\right)_{4} / \mathrm{LiCl}$ [67].

Table 3. Crystal structures of Y-borohydrides.

\begin{tabular}{|c|c|c|c|}
\hline $\begin{array}{l}\text { Material and Hydrogen } \\
\text { Content [wt.\%] }\end{array}$ & Structural Parameters $\left[\AA \AA^{\circ}\right]$ & Atomic Positions & Reference and Comments \\
\hline \multirow[b]{2}{*}{$\underset{9.06}{\left.\alpha-\mathrm{PH}_{4}\right)_{3}}$} & $\begin{array}{l}\text { Space group: cubic Pa-3 (205) } \\
\qquad \begin{array}{c}a=b=c=10.894 \\
\alpha=\beta=\gamma=90\end{array}\end{array}$ & $\begin{array}{c}\text { Y: } 0.2165,0.2165,0.2165 . \text { B: } 0.1920,0.2475 \\
\text { 0.9671. H1: } 0.2900,0.2540,0.0241 . \text { H2: } \\
\text { 0.1030, 0.2245, } 0.0340 . \text { H3: } 0.1737,0.3481 \\
\text { 0.9181. H4: } 0.2018,0.1626,0.8923\end{array}$ & $\begin{array}{l}\text { Theoretical calculation (predicted } \\
\text { DFT) [53]. Isostructural to } \\
\text { Gd }\left(\mathrm{BH}_{4}\right)_{3} \text { and } \mathrm{Dy}\left(\mathrm{BH}_{4}\right)_{3}\end{array}$ \\
\hline & $\begin{array}{l}\text { Space group: cubic } P a-3 \text { (205) } \\
\qquad \begin{array}{c}a=b=c=10.8522(7) \\
\alpha=\beta=\gamma=90\end{array}\end{array}$ & $\begin{array}{c}\text { Y: } 0.2187(5), 0.2187(5), 0.2187(5) . \text { B: } \\
0.1908(5), 0.2455(8), 0.9659(6) . \text { D1: } \\
0.2849(6), 0.2525(8), 0.0272(7) \text {. D2: } \\
0.1024(7), 0.2215(8), 0.0334(6) . \text { D3: } \\
0.1781(7), 0.3450(7), 0.9189(7) . \text { D4: } \\
\text { 0.1920(7), 0.1626(7), 0.8961(7) }\end{array}$ & Experimental [58] \\
\hline $\begin{array}{l}\beta-\mathrm{Y}\left(\mathrm{BH}_{4}\right)_{3} \\
9.06\end{array}$ & $\begin{array}{l}\text { Space group: cubic } F m-3 c \text { (226) } \\
\qquad \begin{array}{c}a=b=c=11.0086(1) \\
\alpha=\beta=\gamma=90\end{array}\end{array}$ & $\begin{array}{c}\text { Y: 0, 0, 0. B: 0, 0, 0.25. } \\
\text { D1: } 0,0.4075(1), 0.3104(1)\end{array}$ & $\begin{array}{c}\text { Experimental, heat treatment in D } \\
\text { at } 10 \mathrm{MPa} \text { and } 475 \mathrm{~K} \text { [58] }\end{array}$ \\
\hline $\begin{array}{l}\mathrm{LiY}\left(\mathrm{BH}_{4}\right)_{4} \\
10.39\end{array}$ & $\begin{array}{l}\text { Space group: tetragonal } P-42 c \\
\qquad(112) \\
\begin{array}{c}a=b=6.2360(9) ; c=12.491(3) \\
\alpha=\beta=\gamma=90\end{array}\end{array}$ & $\begin{array}{c}\text { B: } 0.7453,0.7453,0.6535 . \text { H1: } 0.7642 \\
0.7596,0.7527 . \text { H2: } 0.8643,0.8647,0.6063 . \\
\text { H3: } 0.5562,0.7854,0.6331 . \text { H4: } 0.7818 \\
\text { 0.5566, 0.6307. Li: } 0,0,0.25 . \text { Y: } 0.5,0.5 \\
0.25 .\end{array}$ & [62] \\
\hline $\begin{array}{l}\mathrm{NaY}\left(\mathrm{BH}_{4}\right)_{4} \\
9.42\end{array}$ & $\begin{array}{l}\text { Space group: orthorhombic } C 222_{1} \\
\left(\begin{array}{c}(20) \\
\mathrm{a}=8.5263(4), \mathrm{b}=12.1357(5), \mathrm{c}= \\
9.0535(4) \\
\alpha=\beta=\gamma=90_{-}\end{array}\right.\end{array}$ & $\begin{array}{c}\text { B1: } 0.4983,0.2701,-0.0300 . \text { B2: } 0.7375 \\
\text { 0.0357, } 0.7498 \text {. H11: } 0.5007,0.3256,0.0800 . \\
\text { H12: } 0.4682,0.1735,0.0018 \text {. H13: } 0.6262 \\
\text { 0.2717, - } 0.0945 \text {. H14: } 0.6025,0.3000 \\
\text { 0.6200. H21: } 0.3559,0.4813,0.7445 \\
\text { H22: } 0.7652,0.1337,0.7245 . \text { H23: } 0.6732 \\
0.0308,0.8723 \text {. H24: } 0.6408,0.0026,0.6589 . \\
\text { Na1: }-0.0604,0,0 . \text { Y1: } 0,0.3478,0.25 .\end{array}$ & [62] \\
\hline$\underset{8.61}{\mathrm{~m}-\mathrm{KY}\left(\mathrm{BH}_{4}\right)_{4}}$ & $\begin{array}{l}\text { Space group: monoclinic } C 2 / c(15) \\
\begin{array}{c}\mathrm{a}=14.8947(18), \mathrm{b}=7.8012(10), \mathrm{c}= \\
8.1130(10) \\
\alpha=\gamma=90.00, \beta=110.167(2)\end{array}\end{array}$ & $\begin{array}{c}\text { Y: 0.5, 0.7966(5), 0.25. K: 0.25, 0.25, 0. B1: } \\
\text { 0.1338(13), 0.881(2), 0.767(2). H11: } \\
0.078(10), 0.90(5), 0.625(7) . \text { H21: } 0.104(16), \\
\text { 0.94(4), 0.872(10). H31: 0.21(2), 0.95(7), } \\
0.78(2) . \text { H41: } 0.15(4), 0.733(13), 0.79(2) . \text { B2: } \\
\text { 0.0792(11), 0.5812(18), 0.108(3). H12: } \\
0.146(5), 0.58(4), 0.238(9) . \text { H22: } 0.102(10), \\
0.62(3),-0.011(10) \text { H32: } 0.02(2), 0.68(4), \\
0.123(18) . \text { H42: } 0.05(3), 0.44(2), 0.082(15)\end{array}$ & $460 \mathrm{~K}[68]$ \\
\hline
\end{tabular}


Table 3. Cont.

\begin{tabular}{|c|c|c|c|}
\hline $\begin{array}{l}\text { Material and Hydrogen } \\
\text { Content [wt.\%] }\end{array}$ & Structural Parameters $\left[\AA^{\mathbf{A}},{ }^{\circ}\right]$ & Atomic Positions & Reference and Comments \\
\hline $\begin{array}{l}\mathrm{o}-\mathrm{KY}\left(\mathrm{BH}_{4}\right)_{4} \\
8.61\end{array}$ & $\begin{array}{l}\text { Space group: orthorhombic Cmcm } \\
\qquad \begin{array}{c}(63) \\
\mathrm{a}=8.59314(10), \mathrm{b}=12.59917(15), \mathrm{c} \\
=9.78460(12) \\
\alpha=\beta=\gamma=90\end{array}\end{array}$ & $\begin{array}{c}\text { K: } 0,0,0.5 . \text { Y: } 0.5,0.13211(7), 0.75 . \text { B1: } 0.5 \\
\text { 0.2416(4), 0.9513(6). H11: } 0.6074(10), \\
0.2595(4), 0.8887(8) . \text { H13: } 0.5,0.2924(6) \\
\text { 1.0464(11). H14: } 0.5,0.1550(9), 0.9813(6) \\
\text { B2: } 0.7244(5), 0.0127(4), 0.75 . \text { H21: } \\
\text { 0.8318(11), -0.0390(6), 0.75. H22: } \\
0.7602(6), 0.0990(9), 0.75 . \text { H23: } 0.6529(9) \\
-0.0045(4), 0.8443(9)\end{array}$ & $420 \mathrm{~K}[68]$ \\
\hline $\begin{array}{c}\mathrm{o}-\mathrm{RbY}\left(\mathrm{BH}_{4}\right)_{4} \\
6.90\end{array}$ & $\begin{array}{l}\text { Space group: orthorhombic Pnma } \\
\qquad \begin{array}{c}(62) \\
\mathrm{a}=12.3406(3), \mathrm{b}=8.2482(2), \mathrm{c}= \\
10.5934(3) \\
\alpha=\beta=\gamma=90\end{array}\end{array}$ & $\begin{array}{c}\text { Rb: } 0.1816(3), 0.25,0.6609(5) . \text { Y: } 0.0415(3) \\
0.25,0.1771(6) . \text { B1: } 0.056(3), 0.027(3), \\
0.315(3) . \text { H11: } 0.06(4),-0.084(12), \\
0.386(10) . \text { H12: } 0.06(3),-0.022(14) \\
0.211(7) . \text { H13: } 0.13(4), 0.11(7), 0.330(14) \\
\text { H14: }-0.02(3), 0.10(8), 0.336(13) . \text { B2: } \\
0.212(3), 0.25,0.070(4) . \text { H21: } 0.214(19), 0.25 \\
0.181(7) . \text { H22: } 0.167(7), 0.367(6), 0.033(11) \\
\text { H23: } 0.302(9), 0.25,0.03(2) . \text { B3: } 0.389(4) \\
0.25,0.454(4) . \text { H31: } 0.364(14), 0.25,0.346(8) . \\
\text { H32: } 0.440(5), 0.367(6), 0.476(10) . \text { H33: } \\
0.310(10), 0.25,0.517(15)\end{array}$ & $400 \mathrm{~K}[68]$ \\
\hline $\begin{array}{c}\mathrm{c}-\mathrm{Rb}_{3} \mathrm{Y}\left(\mathrm{BH}_{4}\right)_{6} \\
5.57\end{array}$ & $\begin{array}{l}\text { Space group: cubic Fm-3 (202) } \\
\qquad \begin{array}{c}\mathrm{a}=\mathrm{b}=\mathrm{c}=11.5998(3) \\
\alpha=\beta=\gamma=90\end{array}\end{array}$ & $\begin{array}{c}\text { Rb: } 0.31,0.25,0.25 . \mathbf{Y 1 a}(\mathbf{Y}): 0.04,0,0 . \text { Y1b } \\
(\mathbf{R b}): 0.04,0,0 . \text { Y2a }(\mathbf{R b}): 0.5,0.5,0.5 . \mathbf{Y 2 b} \\
(\mathbf{Y}): 0.5,0.5,0.5 . \mathbf{B :} 0.5,-4.930381 \mathrm{e}-032 \\
0.269(6) \\
\begin{array}{c}\text { H: } 0.580(18), 0.00000017(4), 0.325(14) \mathrm{H}: 0.5 \\
-0.080(18), 0.212(14)\end{array}\end{array}$ & $490 \mathrm{~K}$, cubic [68] \\
\hline $\begin{array}{l}\mathrm{Cs}_{3} \mathrm{Y}\left(\mathrm{BH}_{4}\right)_{6} \\
4.19\end{array}$ & $\begin{array}{l}\text { Space group: cubic } F m-3 \text { (202) } \\
\qquad \begin{array}{c}\mathrm{a}=\mathrm{b}=\mathrm{c}=12.2541(2) \\
\alpha=\beta=\gamma=90\end{array}\end{array}$ & $\begin{array}{c}\text { Cs: } 0.31,0.25,0.25 . \text { Y1a (Y): } 0.029(8), 0,0 \\
\text { Y1b (Cs): } 0.029(8), 0,0 . \text { Y2a (Cs): } 0.452(3) \\
0.5,0.5 . \text { Y2b (Y): } 0.452(3), 0.5,0.5 \text {. B: } 0.5,0 \\
0.254(11) . \text { H: } 0.575(14) 0.00000016(3) \\
0.308(15) . \text { H: } 0.5,-0.075(14), 0.201(15)\end{array}$ & $553 \mathrm{~K}[68]$ \\
\hline $\begin{array}{l}\mathrm{Rb}_{2} \mathrm{LiY}\left(\mathrm{BH}_{4}\right)_{6} \\
6.80\end{array}$ & $\begin{array}{l}\text { Space group: cubic Fm-3 (202) } \\
\qquad \begin{array}{c}\mathrm{a}=\mathrm{b}=\mathrm{c}=11.44541(7) \\
\alpha=\beta=\gamma=90\end{array}\end{array}$ & $\begin{array}{c}\text { Rb: } 0.25,0.25,0.25 . \text { Y1a (Y): 0, 0, 0. Y1b } \\
(\mathbf{L i}): 0,0,0 \text {. Li2a (Li): 0.5, 0.5, 0.5. Li2b (Y): } \\
0.5,0.5,0.5 \text {. B: } 0.5,0,0.2605(7) \text {. H: } 0.584(3) \\
0.000000176(7), 0.320(2) \text {. H: } 0.5,-0.084(3) \\
0.201(2)\end{array}$ & $415 \mathrm{~K}[68]$ \\
\hline$\underset{5.37}{\mathrm{Cs}_{2} \mathrm{LiY}\left(\mathrm{BH}_{4}\right)_{6}}$ & $\begin{array}{l}\text { Space group: cubic } F m-3 \text { (202) } \\
\qquad \begin{array}{c}\mathrm{a}=\mathrm{b}=\mathrm{c}=11.25215(19) \\
\alpha=\beta=\gamma=90\end{array}\end{array}$ & $\begin{array}{c}\text { Cs: } 0.25,0.25,0.25 . \text { Y: } 0,0,0 . \text { Li: } 0.5,0.5, \\
\text { 0.5. B:0.5, 0, 0.2508(2). H: 0.5824(5), } \\
\text { 0.0000001720(11), 0.3091(4). H: } 0.5 \\
-0.0824(5), 0.1925(4), 0.5\end{array}$ & Room temperature [68] \\
\hline
\end{tabular}

\subsection{Group 4: Titanium, Zirconium, and Hafnium}

$\mathrm{Ti}\left(\mathrm{BH}_{4}\right)_{3}$ is an unstable, volatile material that decomposes spontaneously at room temperature $[70,71]$. The first attempt to produce it involved the reaction between a bed of $\mathrm{LiBH}_{4}$ (in excess) and vapors of $\mathrm{TiCl}_{4}$, and it was performed by Hoekstra and Katz in 1949 [72]. Since then, it has been observed that $\mathrm{Ti}^{+4}$ reduced to $\mathrm{Ti}^{+3}$, and, thus, the impracticability of a tetra-borohydride of titanium has been apparent [72]:

$$
2 \mathrm{TiCl}_{4}+8 \mathrm{LiBH}_{4} \rightarrow 2 \mathrm{Ti}\left(\mathrm{BH}_{4}\right)_{3}+8 \mathrm{LiCl}+\mathrm{B}_{2} \mathrm{H}_{6}+\mathrm{H}_{2}
$$

The reaction in organic solvents (tetrahydrofuran or ether) between $\mathrm{LiBH}_{4}$ and $\mathrm{TiCl}_{4}$ ended in the formation of adducts such as $\mathrm{Ti}\left(\mathrm{BH}_{4}\right)_{3} \cdot 2 \mathrm{THF}$ or $\mathrm{Ti}\left(\mathrm{BH}_{4}\right)_{3} \cdot 2 \mathrm{O}\left(\mathrm{C}_{2} \mathrm{H}_{5}\right)_{2}[73]$. In fact, several phosphines of titanium borohydrides (similarly produced to the latter compounds) are stable materials that can be used as a catalyst for polymerization and hydrogenation of olefins $[21,74]$. The only report on the synthesis of $\operatorname{Ti}\left(\mathrm{BH}_{4}\right)_{3}$ in the solidstate was published by Fang et al. in 2009 [75]. They proposed the in-situ formation of $\mathrm{Ti}\left(\mathrm{BH}_{4}\right)_{3}$ after ball-milling of $3 \mathrm{LiBH}_{4}$ and $\mathrm{TiF}_{3}$ and further heating up to $403 \mathrm{~K}$. Fang et al. also recommend not using $\mathrm{TiCl}_{3}$, as the result is the decomposition of $\mathrm{LiBH}_{4}$ in the milling process [75]. The tested materials released over $5 \mathrm{wt} \%$ of hydrogen at about 343-363 K. In the same work, the identification of $\mathrm{Ti}\left(\mathrm{BH}_{4}\right)_{3}$ was achieved by in-situ infrared spectroscopy during heating. During these in-situ measurements, the emergence of IR bands around 1500-1600 and $2500 \mathrm{~cm}^{-1}$ at about $353 \mathrm{~K}$, and further depleting at roughly $363 \mathrm{~K}$, were 
critical to detect the formation of $\mathrm{Ti}\left(\mathrm{BH}_{4}\right)_{3}$. Further decomposition of $\mathrm{Ti}\left(\mathrm{BH}_{4}\right)_{3}$ led to $\mathrm{B}$, $\mathrm{TiH}_{2}$, and $\mathrm{H}_{2}$; the proposed complete reaction is: [75]

$$
3 \mathrm{LiBH}_{4}+\mathrm{TiF}_{3} \rightarrow \mathrm{Ti}\left(\mathrm{BH}_{4}\right)_{3}+3 \mathrm{LiF} \rightarrow 3 \mathrm{~B}+\mathrm{TiH}_{2}+5 \mathrm{H}_{2}+3 \mathrm{LiF}
$$

Later in 2014, Callini et al. reported the formation of $\mathrm{Ti}\left(\mathrm{BH}_{4}\right)_{3}$ by milling or mixing (few details were reported) an excess of $\mathrm{LiBH}_{4}$ and $\mathrm{TiCl}_{3}$ [35]. In that work, the formation of $\mathrm{Ti}\left(\mathrm{BH}_{4}\right)_{3}$ occurred on the surface of the mixtures; then, the compound was expelled to the gas phase. The decomposition of $\mathrm{Ti}\left(\mathrm{BH}_{4}\right)_{3}$ started at room temperature, and essentially ended at $333 \mathrm{~K}$. The decomposition was observed as follows [35]:

$$
\mathrm{Ti}\left(\mathrm{BH}_{4}\right)_{3} \rightarrow \mathrm{B}_{2} \mathrm{H}_{6}+\mathrm{TiH}_{2}+\mathrm{B}+2 \mathrm{H}_{2}
$$

Interestingly, the stabilization of $\mathrm{Ti}\left(\mathrm{BH}_{4}\right)_{3}$ was achieved recently by its confinement in a $\mathrm{Zr}$-based $\mathrm{MOF}\left(\mathrm{Zr}_{6} \mathrm{O}_{4}(\mathrm{DBC})_{6}, \mathrm{DBC}=1,4\right.$-benzenedicarboxylate) $)$ [76]. In such a condition, $\mathrm{Ti}\left(\mathrm{BH}_{4}\right)_{3}$ is reported to decompose through an intermediary stage at $350-430 \mathrm{~K}$ without diborane release. Instead, pentaborane $\left(\mathrm{B}_{5} \mathrm{H}_{9}\right)$ is a dehydrogenation product that recombines at higher temperatures to produce higher boranes [76]. The stabilization was attributed to the occupation of few (1-2) molecules of $\mathrm{Ti}\left(\mathrm{BH}_{4}\right)_{3}$ in the $\mathrm{Zr}$-based MOF pores of comparable size. This stabilization reduces the interaction between $\mathrm{Ti}\left(\mathrm{BH}_{4}\right)_{3}$ molecules in the gas phase and increases the interaction of $\mathrm{Ti}\left(\mathrm{BH}_{4}\right)_{3}$ with the $\mathrm{Zr}$-MOF due to strong host-guest connections [76].

No experimental results on the solid-state molecular structure of $\mathrm{Ti}\left(\mathrm{BH}_{4}\right)_{3}$ have been reported; instead, its molecular structure in the gas phase was reported in 1991 [71] and confirmed by $\mathrm{Ab}$-initio studies in 1993 [77]. The Ti $\left(\mathrm{BH}_{4}\right)_{3}$ molecule poses a $C_{3 h}$ symmetry with a planar $\mathrm{Ti}^{-} \mathrm{B}_{3}$ skeleton, and the $\left[\mathrm{BH}_{4}\right]^{-1}$ ions are $\eta^{3}$ ligands [71] (Table 4). Dain et al. also suggested, based on vapor pressure measurements, the existence of a $\operatorname{Ti}\left(\mathrm{BH}_{4}\right)_{3}$ dimer having bridging and terminal borohydroborate groups [71]. However, no experimental confirmation has been reported.

Table 4. Molecular parameters of Ti-borohydride.

Material and Hydrogen Content [wt.\%]
Symmetry

$\mathrm{C} 3 \mathrm{~h}$
Atomic Positions [Å]

Ti: 0, 0, 0. B1: 0.14648, 1.91483,

-0.00744 . B2: -1.61184 ,

$-0.84502,0.00457$. B3: 1.53773 ,

$-0.97338,0.00253$. H1:

$-1.10173,1.64998,-0.00544$.

H2: $0.67735,1.51811,1.08297$.

H3: 0.67563, 1.50978,

-1.09559 . H4: -0.78907 ,

$-1.82032,0.00764$. H5:

$\mathrm{Ti}\left(\mathrm{BH}_{4}\right)_{3}$

13.09
$-1.61691,-0.23520,1.12541$.

H6: $-1.61875,-0.24383$,

-1.12091 . H7: 1.97099,

$0.22681,-0.00244$. H8:

1.01724, -1.27698, 1.1273. H9:

$1.01546,-1.28564,-1.11902$.

H10: 0.22774, 3.07799,

-0.01194 . H11: -2.65980 ,

$-1.35621,0.00740$. H12:

$2.50443,-1.62533,0.00429$

\section{Atomic positions were generated by symmetry arguments from selected bond distances reported in [71]}

In a recent review on several materials for hydrogen storage (including metal hydrides, alloys, high entropy systems, borohydrides, etc.), $\mathrm{Rb}_{3} \mathrm{Ti}\left(\mathrm{BH}_{4}\right)_{5}$ and $\mathrm{Cs}_{3} \mathrm{Ti}\left(\mathrm{BH}_{4}\right)_{5}$ are enlisted [24] (and references within). The original sources are two theses which are rather 
difficult to access. Both materials were prepared by mechanical milling (not many details are given in the review) [24]:

$$
3 \mathrm{MBH}_{4}+\mathrm{M}^{\prime} \mathrm{Cl}_{n}+n \mathrm{LiBH}_{4} \rightarrow \mathrm{M}_{3} \mathrm{M}^{\prime}\left(\mathrm{BH}_{4}\right)_{3+\mathrm{n}}+n \mathrm{LiCl},
$$

where $\mathrm{M}=\mathrm{Rb}$, $\mathrm{Cs}$ and $\mathrm{M}^{\prime}=\mathrm{Ti} . \mathrm{Rb}_{3} \mathrm{Ti}\left(\mathrm{BH}_{4}\right)_{5}$ and $\mathrm{Cs}_{3} \mathrm{Ti}\left(\mathrm{BH}_{4}\right)_{5}$ crystalize in tetragonal $\mathrm{I} 4 / \mathrm{mcm}$ space group. The cell dimensions are a = 9.214(3) $\AA$, and $\mathrm{c}=16.130(5) \AA$ in $\mathrm{Rb}_{3} \mathrm{Ti}\left(\mathrm{BH}_{4}\right)_{5}$. For $\mathrm{Cs}_{3} \mathrm{Ti}\left(\mathrm{BH}_{4}\right)_{5}$, the cell dimensions are a $=9.644(8) \AA$, and c $=16.426(15) \AA$ [24].

$\mathrm{Zr}\left(\mathbf{B H}_{4}\right)_{4}$ was first reported in 1949 (reaction (29)) [72]. Later, $\mathrm{Zr}\left(\mathrm{BH}_{4}\right)_{4}$ was prepared by reactions (30), (31), and (32) in ether or THF [78]. However, the separation of the products proved difficult $[79,80]$. After that, the solid-state reaction (32) was implemented [81].

$$
\begin{aligned}
\mathrm{NaZrF}_{5}+2 \mathrm{Al}\left(\mathrm{BH}_{4}\right)_{3} & \rightarrow \mathrm{Zr}\left(\mathrm{BH}_{4}\right)_{4}+2 \mathrm{AlF}_{2} \mathrm{BH}_{4}+\mathrm{NaF} \\
\mathrm{ZrCl}_{4}+2 \mathrm{Al}\left(\mathrm{BH}_{4}\right)_{3} & \rightarrow \mathrm{Zr}\left(\mathrm{BH}_{4}\right)_{4}+2 \mathrm{AlCl}_{2} \mathrm{BH}_{4} \\
3 \mathrm{Zr}\left(\mathrm{OC}_{4} \mathrm{H}_{9}\right)_{4}+8 \mathrm{~B}_{2} \mathrm{H}_{6} & \rightarrow 3 \mathrm{Zr}\left(\mathrm{BH}_{4}\right)_{4}+4 \mathrm{~B}\left(\mathrm{OC}_{4} \mathrm{H}_{9}\right)_{3} \\
\mathrm{ZrCl}_{4}+4 \mathrm{LiBH}_{4} & \rightarrow \mathrm{Zr}\left(\mathrm{BH}_{4}\right)_{4}+4 \mathrm{LiCl}
\end{aligned}
$$

Recently, the preparation of $\mathrm{Zr}\left(\mathrm{BH}_{4}\right)_{4}$ by ball milling (Equation (32) and the homologous reaction with $\mathrm{NaBH}_{4}$ [79]) and recovering by means of sublimation at low temperature $(243 \mathrm{~K})$ was reported [82-85]. $\mathrm{Zr}\left(\mathrm{BH}_{4}\right)_{4}$ is a volatile compound at room temperature, and its gas-phase structure is monomeric $\eta^{3}$, with a tetrahedral arrangement and a rotational barrier of the $\left[\mathrm{BH}_{4}\right]^{-1}$ ions of $13.9 \mathrm{~kJ} / \mathrm{mol}[79,81]$. The sublimation heat is between 55.9 and $56.9 \mathrm{~kJ} / \mathrm{mol}$ [86]. $\mathrm{Zr}\left(\mathrm{BH}_{4}\right)_{4}$ displays d-orbital covalency [87].

The crystal structure of $\mathrm{Zr}\left(\mathrm{BH}_{4}\right)_{4}$ was determined at $100 \mathrm{~K}$ as cubic space group $P-43 m$ (Table 5); in the solid-state, $\left[\mathrm{BH}_{4}\right]^{-1}$ coordination to $\mathrm{Zr}$ is also $\eta^{3}$ (Figure 3) [83]. Crystals of $\mathrm{Zr}\left(\mathrm{BH}_{4}\right)_{4}$ melt at 302-305 K [72,79]. Igoshkin et al., employing molecular dynamics calculations, located a phase transition (solid to liquid or amorphous) at 400 $\mathrm{K}$ [86]. According to Gennari et al., the decomposition overlaps with melting ( $355 \mathrm{~K}$ ) to

\begin{tabular}{|c|c|c|c|}
\hline $\begin{array}{l}\text { Material and Hydrogen } \\
\text { Content }[w t . \%]\end{array}$ & Structural Parameters $\left[\AA{ }^{\circ}{ }^{\circ}\right]$ & Atomic Positions & Reference and Comments \\
\hline $\begin{array}{l}\mathrm{Zr}\left(\mathrm{BH}_{4}\right)_{4} \\
\quad 10.71\end{array}$ & $\begin{array}{l}\text { Space group: cubic } P-43 m \\
\begin{array}{c}(215) \mathrm{a}=\mathrm{b}=\mathrm{c}=5.8387(4) \\
\alpha=\beta=\gamma=90\end{array}\end{array}$ & $\begin{array}{c}\text { Zr: 1, 1, 1. B: } 0.7714(2), 0.7714(2), \\
0.7714(2) . \text { H1: } 0.668(3), 0.668(3), \\
\text { 0.668(3). H2: } 0.956(4), 0.748(2), \\
0.748(2)\end{array}$ & At $100 \mathrm{~K}$ [83] \\
\hline
\end{tabular}
give $\mathrm{ZrB}_{2}, \mathrm{~B}_{2} \mathrm{H}_{6}$, and $\mathrm{H}_{2}$ as reaction products [79]. For their part, Nakamori et al. reported thermal decomposition at $\sim 460 \mathrm{~K}[30]$. To be commented on is that $\mathrm{B}_{2} \mathrm{H}_{6}$ formation was detected even during ball-milling synthesis [79].

Table 5. Crystal structures of Zr-borohydrides.

Similar to other transition metal elements, $\mathrm{Zr}$ can form ions of the type $\left[\mathrm{Zr}\left(\mathrm{BH}_{4}\right)_{5}\right]^{-1}[88]$ :

$$
\mathrm{LiBH}_{4}+\mathrm{Zr}\left(\mathrm{BH}_{4}\right)_{4} \rightarrow \mathrm{LiZr}\left(\mathrm{BH}_{4}\right)_{5}
$$

However, $\operatorname{LiZr}\left(\mathbf{B H}_{4}\right)_{5}$ is unstable and decomposes into the initial borohydrides at $\sim 253 \mathrm{~K}$.

In a DOE annual progress report, $\mathbf{N a}_{2} \mathbf{Z r}\left(\mathbf{B H}_{4}\right)_{6}$ is briefly mentioned [89]: "unlike $\mathrm{Zr}\left(\mathrm{BH}_{4}\right)_{4},\left(\mathrm{Na}_{2} \mathrm{Zr}\left(\mathrm{BH}_{4}\right)_{6}\right)$ is non-volatile and undergoes rapid elimination of $2-3 \mathrm{wt} \% \mathrm{H}_{2}$ at 40-110 ${ }^{\circ} \mathrm{C}$ with no detectable $\mathrm{B}_{2} \mathrm{H}_{6}$ contamination". Other attempts to stabilize $\mathrm{Zr}\left(\mathrm{BH}_{4}\right)_{4}$ include: (a) formation of combined coordination compounds, with $\mathrm{NH}_{3}$ as a ligand [84,85]; (b) formation of coordination compounds with other ligands [90]; and (c) the formation of a composite with cross-linked poly(4-vinylpyridine), which is a non-hygroscopic material that is stable for months [91]. 
$\mathbf{H f}\left(\mathbf{B H}_{4}\right)_{4}$ and $\mathrm{Zr}\left(\mathrm{BH}_{4}\right)_{4}$ present similarities in chemistry and properties, such as crystal structure, bonding, and possible use as thin-film precursors. $\mathrm{Hf}\left(\mathrm{BH}_{4}\right)_{4}$ was also first produced in 1949 by a reaction analogous to reaction (29)) [72]. Later, the equivalent of reaction (32) in the solid-state was demonstrated [87,92]. $\mathrm{Hf}\left(\mathrm{BH}_{4}\right)_{4}$ is also a volatile compound at room temperature, and its gas-phase structure is monomeric $\eta^{3}$, with tetrahedral arrangement and high vapor pressure ( 2 $\mathrm{kPa}$ at RT) [11,72,81,92]. The crystal structure of $\mathrm{Hf}\left(\mathrm{BH}_{4}\right)_{4}$ was determined at $110 \mathrm{~K}$ : cubic space group $P-43 m$ in the solid-state (Table 6); $\left[\mathrm{BH}_{4}\right]^{-1}$ coordination to $\mathrm{Hf}$ is $\eta^{3}$, with d-orbital covalency $[87,93]$. As in the case of $\mathrm{Zr}$, Hf can form a complex ion, $\left[\mathrm{Hf}\left(\mathrm{BH}_{4}\right)_{5}\right]^{-1}[88]$ :

$$
\mathrm{LiBH}_{4}+\mathrm{Hf}\left(\mathrm{BH}_{4}\right)_{4} \stackrel{\text { ether, }}{\rightarrow} \text { 195K } \mathrm{LiHf}\left(\mathrm{BH}_{4}\right)_{5},
$$

which is unstable at low temperature and decomposes $(\sim 253 \mathrm{~K})$ to produce the precursor materials [88]. The decomposition of $\mathrm{Hf}\left(\mathrm{BH}_{4}\right)_{4}$ produces $\mathrm{HfB}_{2}, \mathrm{~B}_{2} \mathrm{H}_{6}$, and $\mathrm{H}_{2}$ [11]. A possible use of $\mathrm{Hf}\left(\mathrm{BH}_{4}\right)_{4}, \mathrm{Zr}\left(\mathrm{BH}_{4}\right)_{4}$, and $\mathrm{Ti}\left(\mathrm{BH}_{4}\right)_{3}$ is as precursors for metal borides thin films; the proved advantages are a low temperature of the CVD process and a high conductivity in the thin films $[11,94,95]$.

Table 6. Crystal structures of Hf-borohydrides.

\begin{tabular}{|c|c|c|c|}
\hline $\begin{array}{c}\text { Material and Hydrogen } \\
\text { Content [wt. } \%]\end{array}$ & Structural Parameters $\left[\AA \AA^{\circ}{ }^{\circ}\right]$ & Atomic Positions & Reference and Comments \\
\hline $\begin{array}{c}\mathrm{Hf}\left(\mathrm{BH}_{4}\right)_{4} \\
\quad 6.78\end{array}$ & $\begin{array}{l}\text { Space group: cubic } P-43 m \\
\begin{array}{c}(215) \mathrm{a}=\mathrm{b}=\mathrm{c}=5.8387(4) \\
\alpha=\beta=\gamma=90\end{array}\end{array}$ & $\begin{array}{c}\text { Hf: } 0,0,0 . \text { B: } 0.226(2), 0.226 \\
\text { 0.226. H1: } 0.340(5), 0.340 \\
0.340 . \text { H2: } 0.258(2), 0.258 \\
0.019(2)\end{array}$ & At $100 \mathrm{~K}$ [93] \\
\hline
\end{tabular}

\subsection{Group 5, Vanadium, Niobium and Tantalum}

Few reports on vanadium borohydrides were located during the preparation of this review. In 2011, Yang et al. reported the formation of $\mathbf{V}\left(\mathbf{B H}_{4}\right)_{3}$ by employing mechanical milling of $\mathrm{NaBH}_{4}$ and $\mathrm{VCl}_{3}$ [96].

$$
3 \mathrm{NaBH}_{4}+\mathrm{VCl}_{3} \rightarrow \mathrm{V}\left(\mathrm{BH}_{4}\right)_{3}+3 \mathrm{NaCl}
$$

It is worth mentioning that the temperature in Yang's ball millings was carefully controlled at $258 \mathrm{~K}$ and $293 \mathrm{~K}$ by means of a cooling jacket [96]. In the same work, characterization by XRD after-milling did not give clear evidence of the formation of $\mathrm{V}\left(\mathrm{BH}_{4}\right)_{3}$; however, changes in the dehydrogenation pathway compared to pure $\mathrm{NaBH}_{4}$ served as an indirect proof [96]. The same low crystallinity of the milled products was observed by Korablov et al. in mixtures of $\mathrm{LiBH}_{4}-\mathrm{VCl}_{2}$ and $\mathrm{NaBH}_{4}-\mathrm{VCl}_{2}$ [97]. Dehydrogenation of $\mathrm{V}\left(\mathrm{BH}_{4}\right)_{3}$ by Yang et al. occurred in a three-step process, with main weight losses at $343 \mathrm{~K}, 416 \mathrm{~K}$, and $518 \mathrm{~K}$ [96]. The dehydrogenation enthalpy was calculated as $25.4 \mathrm{~kJ} / \mathrm{mol} \mathrm{V}\left(\mathrm{BH}_{4}\right)_{3}$ [96]. In the report by Korablov et al., a new vanadium borohydride that decomposed at $\sim 463 \mathrm{~K}$ was assumed [97].

A bi-cationic borohydride of Vanadium was reported as $\mathrm{NaV}\left(\mathrm{BH}_{4}\right)_{4} \cdot 3 \mathrm{DME}$ (DME = 1,2-dimethoxyethane) [98]:

$$
\begin{gathered}
5 \mathrm{NaBH}_{4}+\mathrm{VCl}_{4} \stackrel{\mathrm{DME}}{\rightarrow} \mathrm{NaV}\left(\mathrm{BH}_{4}\right)_{4} \cdot 3 \mathrm{DME}+4 \mathrm{NaCl}+\mathrm{B}_{2} \mathrm{H}_{6}+\mathrm{H}_{2} \\
4 \mathrm{NaBH}_{4}+\mathrm{VCl}_{3} \stackrel{\mathrm{DME}}{\rightarrow} \mathrm{NaV}\left(\mathrm{BH}_{4}\right)_{4} \cdot 3 \mathrm{DME}+3 \mathrm{NaCl}
\end{gathered}
$$

$\mathrm{NaV}\left(\mathrm{BH}_{4}\right)_{4} \cdot 3 \mathrm{DME}$ decomposes at 353-378 $\mathrm{K}$ to produce $\mathrm{H}_{2}, \mathrm{~B}_{2} \mathrm{H}_{6}$, and DME [98]. Alternatively, Jensen et al. reported the reactions of $\mathrm{VOCl}_{3}, \mathrm{VCl}_{4}$, or $\mathrm{VCl}_{3}$ with $\mathrm{NaBH}_{4}$ in an organic solvent that produced [Na(DME)][V( $\left.\left(\mathrm{BH}_{4}\right)_{4}\right]$ [99]. Treatment of that compound with $\mathrm{PMe}_{3}$, or the reaction of $\mathrm{LiBH}_{4}$ with $\mathrm{VCl}_{3}\left(\mathrm{PMe}_{3}\right)_{2}$, produced $\mathrm{V}\left(\mathrm{BH}_{4}\right)_{3}\left(\mathrm{PMe}_{2}\right)_{3}[99,100]$. 
The analogous reaction between $\mathrm{VCl}_{2}(\mathrm{dmpe})_{2}$ and $\mathrm{NaBH}_{4}$ produced $\mathrm{V}\left(\mathrm{BH}_{4}\right)_{2}(\mathrm{dmpe})_{2}$ (dmpe $=1,2-B i s$ (dimethylphosphino)ethane) [100]. In the different reactions considered in all these reports, $\left[\mathrm{V}\left(\mathrm{BH}_{4}\right)_{4}\right]^{-1}$ and $\mathrm{V}\left(\mathrm{BH}_{4}\right)_{3}$ seem to become stabilized with solvents and other ligands. Theoretical calculations indicate that $\mathrm{NaV}\left(\mathrm{BH}_{4}\right)_{4}$ and $\mathrm{LiV}\left(\mathrm{BH}_{4}\right)_{4}$ (i.e., $\left.\left[\mathrm{V}\left(\mathrm{BH}_{4}\right)_{4}\right]^{-1}\right)$ would be stable $[101,102]$.

In 1961, Nöth indicated that the reactions between alkali borohydrides $\left(\mathrm{LiBH}_{4}, \mathrm{NaBH}_{4}\right)$ and halides of $\mathrm{Hf}, \mathrm{Th}, \mathrm{V}, \mathrm{Nb}, \mathrm{Ta}, \mathrm{Cr}, \mathrm{Mo}, \mathrm{W}$, and $\mathrm{U}$, were not reported at that time [103]. Until now (2021), no homoleptic Nb-borohydrides have been reported. Compared to $\mathrm{Nb}$-alanates, for which a relatively wide variety of materials have been reported [104] (and references within), the lack of homoleptic $\mathrm{Nb}$-borohydrides is exceptional. Alanates of the same metal are in general less stable than the corresponding borohydrides. Concerning Ta, no reports on borohydrides of this metal were located during the preparation of this review.

\subsection{Group 6: Chromium, Molybdenum and Tungsten}

Some old reports on Cr(II) heteroleptic complexes with THF (2 solvent molecules) [105], TMDEA (Tetramethylethylenediamine), or Py (pyridine) [106] have been found. In particular, $\mathrm{Cr}\left(\mathrm{BH}_{4}\right)_{2} \cdot 2 \mathrm{THF}$ was produced between 231 and $253 \mathrm{~K}$, being unstable at room temperature [105]. Nakamori et al. reported the reaction between $\mathrm{LiBH}_{4}$ and chromium chloride; however, no clear indication of the formation of chromium borohydride was presented in the data from infrared spectroscopy and hydrogen release by thermal desorption [107]. A theoretical report indicates that a hypothetical $\mathrm{Cr}\left(\mathrm{BH}_{4}\right)_{4}$ is unstable, but $\left[\mathrm{Cr}\left(\mathrm{BH}_{4}\right)_{4}\right]^{-1}$ might be stabilized by a bulky cation [102]. In fact, $\mathrm{Rb} 3{ }_{3} \mathrm{Cr}\left(\mathrm{BH}_{4}\right)_{5}$ and $\mathrm{Cs}_{3} \mathrm{Cr}\left(\mathrm{BH}_{4}\right)_{5}$ were produced recently by mechanical milling (Equation (28) with $\mathrm{M}^{\prime}=\mathrm{Cr}$ ), and they crystalized in tetragonal $\mathrm{P4}_{2} / \mathrm{mbc}$ [24]. The cell size of $\mathrm{Rb}_{3} \mathrm{Cr}\left(\mathrm{BH}_{4}\right)_{5}$ was reported as a $=9.182(3) \AA$ and $\mathrm{c}=16.209(6) \AA$; while the cell size of $\mathrm{Cs}_{3} \mathrm{Cr}\left(\mathrm{BH}_{4}\right)_{5}$ corresponds to $\mathrm{a}=9.578(4) \AA$ and $\mathrm{c}=16.544(12) \AA$ [24].

To the best of our knowledge, no experimental reports of homoleptic Mo and W borohydrides have been published.

\subsection{Group 7: Manganese, Technetium and Rhenium}

Manganese borohydrides have generated a large interest in recent years (mainly from 2010 to 2015 ) due to their high hydrogen content (9.53 wt.\%), a certain balance between stability and low dehydrogenation temperature, and their similarities with $\mathrm{Mg}\left(\mathrm{BH}_{4}\right)_{2}$ in chemistry and crystal structures. $\mathbf{M n}\left(\mathbf{B H}_{4}\right)_{2}$ can be produced by a metathesis reaction between $2 \mathrm{MBH}_{4}$ and $\mathrm{MnCl}_{2}(\mathrm{M}=\mathrm{Li}, \mathrm{Na}$ or $\mathrm{K})$ in organic solvents with further solvent extraction, or by solid-state metathesis promoted by ball milling, with or without further purification, using solvents such as $\mathrm{S}\left(\mathrm{CH}_{3}\right)_{2}[108,109]$. These methods give different yields and purities [108,110]. Particularly, the presence of a second metathesis product (i.e., $\mathrm{LiCl}$ or $\mathrm{NaCl}$ ) could be important; reports suggest the possibility of partial substitution of $\left[\mathrm{BH}_{4}\right]^{-}$by $\mathrm{Cl}^{-}$ions [111,112]. Details of the synthesis technique are important: in the preparation using THF, the solvated material, $\mathrm{Mn}\left(\mathrm{BH}_{4}\right)_{2} \cdot(\mathrm{THF})_{3}$, was obtained [113]; attempts to remove the solvent led to decomposition. However, another researcher successfully used THF and $\mathrm{NaBH}_{4}$ plus $\mathrm{MnCl}_{2}$ as precursors [114]. Solvent-free $\mathrm{Mn}\left(\mathrm{BH}_{4}\right)_{2}$ can also be obtained by using anhydrous ether $[111,114]$. Using a mixture of toluene $\left./ \mathrm{S}_{(\mathrm{CH}}\right)_{2}$, followed by the extraction of the manganese borohydride with $\mathrm{S}\left(\mathrm{CH}_{3}\right)_{2}$, and, finally, proper drying, the synthesis of $\mathrm{Mn}\left(\mathrm{BH}_{4}\right)_{2}$ can be considered reproducible [109]. This last procedure seems to be the most reliable for obtaining pure $\mathrm{Mn}\left(\mathrm{BH}_{4}\right)_{2}$. In the ball-milling preparation, the ratio between milling time and pauses seems very important to achieve the desired product [115]. Additionally, this synthesis method can lead to the formation of nanometric materials $(\sim 10-20 \mathrm{~nm})$ [116] (and references within). A formation enthalpy of $-58.89 \mathrm{~kJ} / \mathrm{f} . \mathrm{u}$. (f.u. = formula unit) and a half-metallic nature of $\mathrm{Mn}\left(\mathrm{BH}_{4}\right)_{2}$ were determined through firstprinciple calculations [117]. Additionally, a low thermodynamic barrier for the metathesis reaction between $\mathrm{LiBH}_{4}$ and $\mathrm{MnCl}_{2}$ was observed [118]. 
Several polymorphs of $\mathrm{Mn}\left(\mathrm{BH}_{4}\right)_{2}$ have been reported (Figure 5, Table 7) [109,111,115]. The $\alpha-\mathrm{Mn}\left(\mathrm{BH}_{4}\right)_{2}$ phase belongs to the trigonal $P 3_{1} 12$ space group symmetry, where $\mathrm{Mn}$ atoms are surrounded by four $\left[\mathrm{BH}_{4}\right]^{-}$ions in a distorted tetrahedral fashion [115], similar to $\mathrm{P}_{1} 12 \mathrm{Mg}\left(\mathrm{BH}_{4}\right)_{2}[115,119]$. Drying of $\mathrm{Mn}\left(\mathrm{BH}_{4}\right)_{2} \cdot 1 / 2 \mathrm{~S}\left(\mathrm{CH}_{3}\right)_{2}$ (after synthesis in toluene $\left./ 2 \mathrm{~S}\left(\mathrm{CH}_{3}\right)_{2}\right)$ under vacuum at room temperature for three days produced $\gamma-\mathrm{Mn}\left(\mathrm{BH}_{4}\right)_{2}$ (cubic $\left.I d-3 a\right)$, which is a nanoporous material similar to the zeolite-like $\gamma$ $\mathrm{Mg}\left(\mathrm{BH}_{4}\right)_{2}$ [109]. Some $\mathrm{Mg}\left(\mathrm{BH}_{4}\right)_{2}$ polymorphs are porous and can store small molecules in them [119]; thus, similar behavior can be expected from $\mathrm{Mn}\left(\mathrm{BH}_{4}\right)_{2}$. High-pressure polymorphs of Mn-borohydrides are: (i) $\delta-\mathrm{Mn}\left(\mathrm{BH}_{4}\right)_{2}$, which consists of two interpenetrating $\mathrm{Mn}\left(\mathrm{BH}_{4}\right)_{2}$ frameworks without voids, and (ii) $\delta^{\prime}-\mathrm{Mn}\left(\mathrm{BH}_{4}\right)_{2}$ [111]. The transition $\delta-\mathrm{Mn}\left(\mathrm{BH}_{4}\right)_{2}$ to $\alpha-\mathrm{Mn}\left(\mathrm{BH}_{4}\right)_{2}$ occurred upon heating at 340-382 $\mathrm{K}$ [111]. The possibility of a metastable $\mathrm{Mn}\left(\mathrm{BH}_{4}\right)_{2}$ phase with tetragonal $P-4 n 2$ symmetry in the pressure range 0-1.5 GPa was also reported [111].

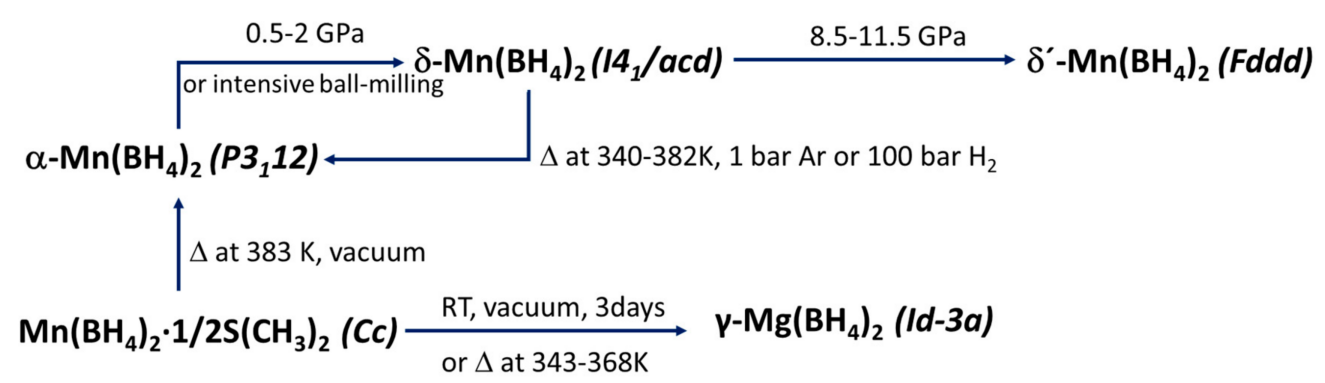

Figure 5. The interrelation of the phases of $\mathrm{Mn}\left(\mathrm{BH}_{4}\right)_{2}$, constructed with information from refs. $[109,111,120]$.

The dehydrogenation temperature of $\alpha-\mathrm{Mn}\left(\mathrm{BH}_{4}\right)_{2}$ (without $\mathrm{LiCl}$ ) was established between 413 and $433 \mathrm{~K}$, depending on pressure conditions (vacuum and 1 bar Ar, respectively) [109]. Hydrogen release at higher temperatures is usually due to the presence of residual precursors, i.e., $\mathrm{LiBH}_{4}$ or $\mathrm{NaBH}_{4}[112,118,121]$. Tomanov et al. reported a slightly wider range of dehydrogenation temperatures, between 403 and $473 \mathrm{~K}$ (without $\mathrm{NaCl})$ [111]. The dehydrogenation reaction of $\alpha-\mathrm{Mn}\left(\mathrm{BH}_{4}\right)_{2}$ can occur even at 100 bar hydrogen pressure [111]. Meanwhile, in a ball-milled sample of $\alpha-\mathrm{Mn}\left(\mathrm{BH}_{4}\right)_{2}(+\mathrm{LiCl})$, manganese borohydride was found to melt at $450 \mathrm{~K}$ [115]. Varin et al. demonstrated good dehydrogenation kinetics under isothermal conditions (373-473 K) of mixtures of $\mathrm{Mn}\left(\mathrm{BH}_{4}\right)_{2}+$ $\mathrm{LiCl}$ (from ball-milled $2 \mathrm{LiBH}_{4}+\mathrm{MnCl}_{2}$ ) [118]. The activation energy was between 70 and $59 \mathrm{~kJ} / \mathrm{mol}$, depending upon the milling conditions and the molar ratio of the precursors $\mathrm{LiBH}_{4}$ and $\mathrm{MnCl}_{2}$ [118]. A material stored at room temperature registered a release of $0.5 \mathrm{wt} . \%$ within a period of 80 days [118].

There is no consensus on the nature of the dehydrogenation products, particularly about the evolution of diborane and related compounds. Several dehydrogenation reactions have been proposed $[112,118,121]$ :

$$
\begin{gathered}
\mathrm{Mn}\left(\mathrm{BH}_{4}\right)_{2} \rightarrow \mathrm{Mn}+2 \mathrm{~B}+4 \mathrm{H}_{2} \\
\mathrm{Mn}\left(\mathrm{BH}_{4}\right)_{2} \rightarrow \mathrm{MnB}_{2}+4 \mathrm{H}_{2} \\
3 \mathrm{Mn}\left(\mathrm{BH}_{4}\right)_{2} \rightarrow 3 \mathrm{Mn}+4 \mathrm{~B}+\mathrm{B}_{2} \mathrm{H}_{6}+9 \mathrm{H}_{2}
\end{gathered}
$$

Regarding the diborane evolution, the terms used to describe the release range from practically undetectable to substantial amounts [109,116,122]. Liu et al. observed a peak of $\mathrm{B}_{2} \mathrm{H}_{6}$ evolution at $421 \mathrm{~K}$ [112], which is practically simultaneous to the hydrogen release. Recently, the addition of filamentary $\mathrm{Ni}$, graphene, or $\mathrm{LiNH}_{2}(5 \mathrm{wt} . \%)$ reduced the $\mathrm{B}_{2} \mathrm{H}_{6}$ release [123].

Several authors agreed about the amorphous nature of the solid products of the dehydrogenation process, particularly in manganese borides. In this way, an interesting X- 
ray absorption spectroscopy study was performed by Guda et al. [124]. In this study, the Mn K-edge spectra of dehydrogenated samples are better described by the existence of $\mathrm{Mn}_{2} \mathrm{~B}$, $\mathrm{MnB}$, and $\mathrm{MnB}_{4}$ than $\mathrm{MnB}_{2}$ and $\mathrm{Mn}_{3} \mathrm{~B}_{4}$ compounds. The authors proposed the formation of the former borides and metallic Mn as the main dehydrogenation products [124]. However, in a recent report, Pankin et al. indicated that metallic Mn does not exceed 5\% [121].

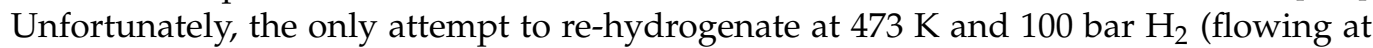
$100 \mathrm{~mL} / \mathrm{min}$ in DSC) did not succeed [112].

Frequently, in addition to the formation of $\mathrm{Mg}\left(\mathrm{BH}_{4}\right)_{2}$, other compounds were obtained, such as bimetallic or solvated materials $\mathrm{K}_{2} \mathrm{Mn}\left(\mathrm{BH}_{4}\right)_{4}$ or $\mathrm{M}\left(\mathrm{Et}_{2} \mathrm{O}\right)_{2} \mathrm{Mn}_{2}\left(\mathrm{BH}_{4}\right)_{5}(\mathrm{M}=\mathrm{Li}$, $\mathrm{Na})[110,123]$. Extraction of the solvent collapses the latter materials to $\mathrm{Mn}\left(\mathrm{BH}_{4}\right)_{2}$ and $\mathrm{MBH}_{4}(\mathrm{M}=\mathrm{Li}, \mathrm{Na})[110]$. The solvated materials of $\left(\mathrm{M}\left(\mathrm{Et}_{2} \mathrm{O}\right)_{2} \mathrm{Mn}_{2}\left(\mathrm{BH}_{4}\right)_{5}\right.$ and $\left.(\mathrm{M}=\mathrm{Li}, \mathrm{Na})\right)$ are insulators, with band gaps of 2.1 and $1.9 \mathrm{eV}$, respectively [110]. Dehydrogenation of $\mathrm{M}\left(\mathrm{Et}_{2} \mathrm{O}\right)_{2} \mathrm{Mn}_{2}\left(\mathrm{BH}_{4}\right)_{5}(\mathrm{M}=\mathrm{Li}, \mathrm{Na})$ involves the evolution of the solvent at $383 \mathrm{~K}$, and the decomposition of $\mathrm{Mn}\left(\mathrm{BH}_{4}\right)_{2}$ at $433 \mathrm{~K}$ [110].

Bimetallic and trimetallic Mn-borohydrides can be of interest. $\operatorname{LiMn}\left(\mathbf{B H}_{4}\right)_{3}$ was reported by Choudhury et al. in 2009. This material was produced by mechanical milling [125]:

$$
3 \mathrm{LiBH}_{4}+\mathrm{MnCl}_{2} \rightarrow \mathrm{LiMn}\left(\mathrm{BH}_{4}\right)_{3}+2 \mathrm{LiCl}
$$

Being an amorphous material, its existence was demonstrated utilizing infrared spectroscopy [125-127]. LiMn $\left(\mathrm{BH}_{4}\right)_{3}$ melts at about $367 \mathrm{~K}$ and undergoes dehydrogenation between 408 and $428 \mathrm{~K}$ [125]. As with other borohydrides, diborane release is a matter of controversy, from pure $\mathrm{H}_{2}$ [125] to $4 \mathrm{~mol}^{\%}$ [126]. Doping with transition metals (nano$\mathrm{Ni}, \mathrm{Co}, \mathrm{Fe}, \mathrm{Ti} \mathrm{Zn}, \mathrm{Cu}, \mathrm{Pd}$ ) [125] or Ti-compounds, such as $\mathrm{TiF}_{3}, \mathrm{TiC}, \mathrm{TiN}$, and $\mathrm{TiO}_{2}$, leads to a small reduction in the activation energy and the dehydrogenation temperature, particularly with $\mathrm{Ni}$ and $\mathrm{TiF}_{3}[125,126]$. Activation energy is reduced from $130.64 \mathrm{~kJ} / \mathrm{mol}$ to $111.55 \mathrm{~kJ} / \mathrm{mol}$ in the Ni-doped material [125]. For the $\mathrm{TiF}_{3}$ doped $\mathrm{LiMn}\left(\mathrm{BH}_{4}\right)_{3}$ material, activation energy was reported as $114 \mathrm{~kJ} / \mathrm{mol}$. The reason for the reduction in activation energy by $\mathrm{TiF}_{3}$ is the partial formation of $\mathrm{Ti}\left(\mathrm{BH}_{4}\right)_{3}$, which decomposes at room temperature [126]. This supports the in-situ formation of $\mathrm{Ti}\left(\mathrm{BH}_{4}\right)_{3}$ observed by Fang et al. in 2009 [75]. Unfortunately, dehydrogenated $\mathrm{LiMn}\left(\mathrm{BH}_{4}\right)_{3}$ seems to be irreversible towards hydrogen uptake [125-127].

Severa et al. mentioned that $\mathrm{Na}_{2} \mathbf{M n}\left(\mathbf{B H}_{4}\right)_{4}$ may be formed during ball milling of $\mathrm{NaBH}_{4}$ with $\mathrm{MnCl}_{2}$ [114]. However, more research about the existence and properties of this material should be performed.

$\mathbf{K}_{2} \mathbf{M n}\left(\mathbf{B H}_{4}\right)_{4}$ was produced as a minor product in a metathesis type reaction in $\mathrm{Et}_{2} \mathrm{O}$ [110], but this material can also be obtained by ball milling of $\mathrm{KBH}_{4}-\mathrm{MnCl}_{2}$ or $\mathrm{Mn}\left(\mathrm{BH}_{4}\right)_{2}$ and $\mathrm{KBH}_{4}[108]$ :

$$
4 \mathrm{KBH}_{4}+2 \mathrm{Mn}\left(\mathrm{BH}_{4}\right)_{2} \rightarrow 2 \mathrm{~K}_{2} \mathrm{Mn}\left(\mathrm{BH}_{4}\right)_{4}
$$

$\mathrm{K}_{2} \mathrm{Mn}\left(\mathrm{BH}_{4}\right)_{4}$ has a monoclinic $P 2_{1} / n$ symmetry (Table 7$)$, and the $\left[\mathrm{Mn}\left(\mathrm{BH}_{4}\right)_{4}\right]^{-2}$ environment was described as a penta-capped trigonal prism [108]. The decomposition of $\mathrm{K}_{2} \mathrm{Mn}\left(\mathrm{BH}_{4}\right)_{4}(420 \mathrm{~K})$ produced $\mathrm{KBH}_{4}$ and $\mathrm{KMn}\left(\mathrm{BH}_{4}\right)_{3}$; the crystal structure of the latter material was not solved unambiguously but proposed as tetragonal $\mathrm{P} 4 / \mathrm{mbm}$ [108]. DFT calculations on $\left[\mathrm{Mn}\left(\mathrm{BH}_{4}\right)_{4}\right]^{-2}$ indicate bidentate $\left[\mathrm{BH}_{4}\right]^{-1}$ interaction with $\mathrm{Mn}$ [114].

$\operatorname{CsMn}\left(\mathbf{B H}_{4}\right)_{3}$ was briefly mentioned in a recent report; it crystallizes in the monoclinic Cc space group symmetry [69]. $\mathbf{R b}_{3} \mathbf{M n}\left(\mathbf{B H}_{4}\right)_{5}$ and $\mathbf{C s}_{3} \mathbf{M n}\left(\mathbf{B H}_{4}\right)_{5}$ were produced by mechanical milling (Equation (28) with $\mathrm{M}^{\prime}=\mathrm{Mn}$ ), and they crystalized in tetragonal $I 4 / \mathrm{mcm}$ [24]. The cell size is $\mathrm{a}=9.2963$ (19) $\AA$, $\mathrm{c}=16.101(3) \AA$ for $\mathrm{Rb}_{3} \mathrm{Mn}\left(\mathrm{BH}_{4}\right)_{5}$, and $\mathrm{a}=9.716(2) \AA, \mathrm{c}=16.3544) \AA$ for $\mathrm{Cs}_{3} \mathrm{Mn}\left(\mathrm{BH}_{4}\right)_{5}[24]$.

As with other interesting borohydrides, the formation of reactive mixtures or composites with $\mathrm{Mn}\left(\mathrm{BH}_{4}\right)_{2}$ is the subject of current research. Mixtures of $\mathrm{Mn}\left(\mathrm{BH}_{4}\right)_{2}+\mathrm{M}\left(\mathrm{BH}_{4}\right)_{\mathrm{x}}$, $\mathrm{M}=\mathrm{Li}, \mathrm{Na}, \mathrm{Mg}$, and $\mathrm{Ca}$ can be prepared by ball-milling from pure borohydrides. For $\mathrm{M}=\mathrm{Mg}$, a solid solution was also formed. $\mathrm{Mn}\left(\mathrm{BH}_{4}\right)_{2}$ and $\mathrm{Mg}\left(\mathrm{BH}_{4}\right)_{2}$ can form a solid 
solution of $\mathrm{Mg}_{\mathrm{x}} \mathrm{Mn}_{(1-\mathrm{x})}\left(\mathrm{BH}_{4}\right)_{2}$ in the range $\mathrm{x}=0-0.8$ from the mixing of $\mathrm{MgCl}_{2}, \mathrm{MnCl}_{2}$, and $\mathrm{LiBH}_{4}$ [128]. This solid solution crystallized in the trigonal form of $\mathrm{Mn}\left(\mathrm{BH}_{4}\right)_{2}$, and it has the advantage of reducing the dehydrogenation temperature as compared with $\mathrm{Mg}\left(\mathrm{BH}_{4}\right)_{2}$ $(425-450 \mathrm{~K})$, while keeping a hydrogen content close to $\mathrm{Mg}\left(\mathrm{BH}_{4}\right)_{2}$ [128]. $\mathrm{Mg}_{\mathrm{x}} \mathrm{Mn}_{(1-\mathrm{x})}\left(\mathrm{BH}_{4}\right)_{2}$ can decompose with very slow kinetics at room temperature [128]. During decomposition, up to $7.5 \mathrm{~mol} \%$ of diborane can be released [128].

Table 7. Crystal structures of Mn-borohydrides.

\begin{tabular}{|c|c|c|c|}
\hline $\begin{array}{l}\text { Material and Hydrogen } \\
\text { Content [wt.\%] }\end{array}$ & Structural Parameters $\left[\AA{ }^{\circ}{ }^{\circ}\right]$ & Atomic Positions & References and Comments \\
\hline $\begin{array}{c}\alpha-\mathrm{Mn}\left(\mathrm{BH}_{4}\right)_{2} \\
9.53\end{array}$ & $\begin{array}{l}\text { Space group: trigonal } P 3_{1} 12(151) \\
\mathrm{a}=10.4349(1), \mathrm{c}=10.835(2) \\
\alpha=\beta=90, \gamma=120\end{array}$ & $\begin{array}{c}\text { Mn1: 0.23130(50), 0.91807(72), 0.12532(40). } \\
\text { Mn2: 0.56272(32), 2x, 0.6666667. B1: } \\
\text { 0.0403(34), 0.6990(30), 1.0056(58). H11: } \\
\text {-0.0824(33), 0.6582(70), 1.0014(67). H12: } \\
\text { 0.0712(79), 0.6455(79), 0.9292(92). H13: } \\
\text { 0.0685(66), 0.6689(49), 1.0980(89) } \\
\text { H14: 0.1041(50), 0.8233(31), 0.9937(44). B2: } \\
\text { 0.4708(31), 2x, 0.1666667. H21: 0.4285(44), } \\
\text { 1.0140(63), 0.206(41). H22: } 0.393(40), \\
\text { 0.8688(61), 0.0914(60). B3: 2y, 0.10206, } 0 . \\
\text { H31: 0.1323(30), 0.1145(36), - -0.0717(24). } \\
\text { H32: 0.2766(30), 0.0642(23), -0.0463(37). B4: } \\
\text { 0.1329(17), 1-x, 0.3333333. H41: } 0.0199(28), \\
\text { 0.8265(39), } 0.3754(44) . \text { H42: } 0.1250(54), \\
\text { 0.7875(42), 0.2588(29). B5: 0.7056(23), 1-x, } \\
\text { 0.8333333. H51: 0.7531(36), 0.4149(28), } \\
\text { 0.8590(98). H52: } 0.716(11), 0.232(10), \\
0.9146(22)\end{array}$ & {$[115]$} \\
\hline $\begin{array}{c}\delta-\mathrm{Mn}\left(\mathrm{BH}_{4}\right)_{2} \\
9.53\end{array}$ & $\begin{array}{c}\text { Space group: tetragonal } I 4_{1} / \mathrm{acd} \\
(142) \\
\mathrm{a}=7.85254(6), \mathrm{b}=7.85254(6), \mathrm{c}= \\
12.14548(17) \\
\alpha=\beta=\gamma=90\end{array}$ & $\begin{array}{c}\text { Mn: } 0,0.25,0.125 . \text { B: } 0.0197(17), 0,0.25, \mathbf{H 1 :} \\
-0.0833(17),-0.01726,0.17047 . \mathbf{H 2 :} \\
0.1247(17), 0.86217,0.24890\end{array}$ & {$[111]$} \\
\hline $\begin{array}{c}\delta^{\prime}-\mathrm{Mn}\left(\mathrm{BH}_{4}\right)_{2} \\
9.53\end{array}$ & $\begin{array}{l}\text { Space group: orthorhombic Fddd } \\
\qquad \begin{array}{c}(70) \\
\mathrm{a}=12.638(15), \mathrm{b}=9.321(10) \\
c=9.205(17) \\
\alpha=\beta=\gamma=90\end{array}\end{array}$ & $\begin{array}{c}\text { Mn: }-0.08981,0.125,0.125, \text { B1: } 0.52633 \\
\text { 0.44943, } 0.21955 \text {. H11: } 0.55862,0.32065 \\
0.21651 . \text { H12: } 0.31244,0.30784,0.26337 . \text { H13: } \\
\text { 0.17630, 0.20909,0.29581. H14: } 0.53619 \\
0.49567,0.09304\end{array}$ & {$[111]$} \\
\hline $\begin{array}{c}\gamma-\mathrm{Mn}\left(\mathrm{BH}_{4}\right)_{2} \\
9.53\end{array}$ & $\begin{array}{l}\text { Space group: cubic } I a-3 d(230) \\
\qquad \begin{array}{c}a=b=c=16.2094(13) \\
\alpha=\beta=\gamma=90\end{array}\end{array}$ & $\begin{array}{c}\text { Mn: } \frac{1}{4}, 1 / 8, \frac{1}{2} . \text { B1: } 0.3090(11), 0.0590(11), \\
\text { 3/8. H1: 0.2849(11), 0.0199(11), } 0.43730 . \text { H2: } \\
\text { 0.2966(11), 0.1347(11), } 0.38560\end{array}$ & [109] \\
\hline $\begin{array}{c}\mathrm{K}_{2} \mathrm{Mn}\left(\mathrm{BH}_{4}\right)_{4} \\
8.38\end{array}$ & $\begin{array}{l}\text { Space group: monoclinic } P 2_{1} / c(14) \\
\quad \begin{array}{c}a=8.1375(7), b=9.8456(7) \\
c=12.7420(12)\end{array} \\
\alpha=90, \beta=100.552(6), \gamma=90\end{array}$ & 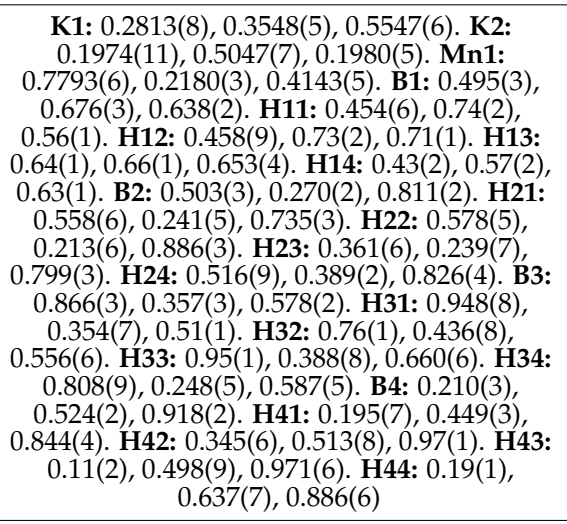 & {$[108]$} \\
\hline $\begin{array}{c}\mathrm{Li}_{3} \mathrm{MnZn}_{5}\left(\mathrm{BH}_{4}\right)_{15} \\
9.67\end{array}$ & $\begin{array}{l}\text { Space group: hexagonal } P 6_{3} / \mathrm{mcm} \\
\qquad \begin{array}{c}(193) \\
a=15.391(3), c=8.590(2) \\
\alpha=\beta=90, \gamma=120\end{array}\end{array}$ & $\begin{array}{c}\text { Zn1: } 1 / 3,2 / 3, \frac{1}{4} . \text { Zn2: 0.2861(4), 0, } \frac{1}{4} . \\
\text { Li/Mn: 0.6089(7), 0, } \frac{1}{4} . \text { Li: 0, 0, 0. B1: } \\
\text { 0.131(1), 0, } \frac{1}{4} . \text { H11: 0.089(2), 0, 0.358(2). H12: } \\
\text { 0.139(2), -0.069(2), } \frac{1}{4} . \text { B2: 0.332(2), 0, } \\
\text { 0.002(2). H21: } 0.296(2), 0,-0.113(2) . \text { H22: } \\
\text { 0.405(2), 0, }-0.021(2) . \text { H23: 0.279(2), } \\
-0.069(2), 0.071(2) . \text { B3: 0.525(1), 0.344(2), } \frac{1}{4} . \\
\text { H31: } 0.443(2), 0.284(2), \frac{1}{4} . \text { H32: } 0.532(2), \\
\text { 0.420(2), } 1 / 4 . \text { H33: } 0.563(2), 0.336(2), 0.142(2)\end{array}$ & $\begin{array}{l}\text { Refined from synchrotron } \\
\text { radiation powder } \\
\text { diffraction data at room } \\
\text { temperature [129] }\end{array}$ \\
\hline
\end{tabular}

For the rest of the $\mathrm{Mn}\left(\mathrm{BH}_{4}\right)_{2}+\mathrm{M}\left(\mathrm{BH}_{4}\right)_{\mathrm{x}}, \mathrm{M}=\mathrm{Li}, \mathrm{Na}$, and Ca composites, the decomposition of the components is not significantly affected by each other. Only small 
differences in the onset dehydrogenation temperature of $\mathrm{Mn}\left(\mathrm{BH}_{4}\right)_{2}$ were observed: $381 \mathrm{~K}$ in the mixture with $\mathrm{LiBH}_{4}, 379 \mathrm{~K}$ with $\mathrm{NaBH}_{4}$, and $356 \mathrm{~K}$ with $\mathrm{Ca}\left(\mathrm{BH}_{4}\right)_{2}$ [120].

The composites of $\mathrm{Mn}\left(\mathrm{BH}_{4}\right)_{2}+\mathrm{MH}_{\mathrm{x}}, \mathrm{M}=\mathrm{Li}, \mathrm{Na}$, and $\mathrm{Ca}$, exhibit the same dehydrogenation mechanism; the decomposition of $\mathrm{Mn}\left(\mathrm{BH}_{4}\right)_{2}$ overlapped with the formation of $\mathrm{M}\left(\mathrm{BH}_{4}\right)_{x}[120]$ :

$$
\mathrm{Mn}\left(\mathrm{BH}_{4}\right)_{2}+\frac{2}{3 x} \mathrm{MH}_{\mathrm{x}} \rightarrow \mathrm{Mn}+y \mathrm{~B}+3 \mathrm{H}_{2}+\frac{2}{3 x} \mathrm{M}\left(\mathrm{BH}_{4}\right)_{\mathrm{x}}
$$

For the mixture of $\mathrm{Mn}\left(\mathrm{BH}_{4}\right)_{2} / \mathrm{MgH}_{2}$, no formation of $\mathrm{Mg}\left(\mathrm{BH}_{4}\right)_{2}$ was observed, and the dehydrogenation of the components appears to be independent of each other: 373-394 $\mathrm{K}$ for $\mathrm{Mn}\left(\mathrm{BH}_{4}\right)_{2}$ and $503-615 \mathrm{~K}$ for $\mathrm{MgH}_{2}$ [120].

$\mathbf{L i}_{3} \mathbf{M n Z n}_{5}\left(\mathbf{B H}_{4}\right)_{15}$ (Table 7) can be produced by mechanical milling of $\mathrm{LiBH}_{4}$ and some salts [129]:

$$
\begin{gathered}
15 \mathrm{LiBH}_{4}+5 \mathrm{MnCl}_{2}+5 \mathrm{ZnCl}_{2} \rightarrow \mathrm{Li}_{3} \mathrm{MnZn}_{5}\left(\mathrm{BH}_{4}\right)_{15}+4 \mathrm{LiCl}+4 \mathrm{Li}_{2} \mathrm{MnCl}_{4} \\
13 \mathrm{LiBH}_{4}+\mathrm{Mn}\left(\mathrm{BH}_{4}\right)_{2}+5 \mathrm{ZnCl}_{2} \rightarrow \mathrm{Li}_{3} \mathrm{MnZn}_{5}\left(\mathrm{BH}_{4}\right)_{15}+10 \mathrm{LiCl}
\end{gathered}
$$

Reaction (45) can be preferred over the reaction (44) due to a competing reaction to form $\mathrm{LiZn}_{2}\left(\mathrm{BH}_{4}\right)_{5}$ in the last one. Decomposition of $\mathrm{Li}_{3} \mathrm{MnZn}_{5}\left(\mathrm{BH}_{4}\right)_{15}$ occurs at $385 \mathrm{~K}$ to produce $\mathrm{LiZn}\left(\mathrm{BH}_{4}\right)_{5}, \mathrm{LiBH}_{4}$, and $\mathrm{Mn}\left(\mathrm{BH}_{4}\right)_{2}$ [129].

No reports on technetium and rhenium borohydrides have been published.

\subsection{Group 8: Iron, Ruthenium, and Osmium}

$\mathrm{Fe}\left(\mathrm{BH}_{4}\right)_{2}$ has a total hydrogen content of $9.42 \mathrm{wt}$.\%. Schaeffer et al. prepared the mixture of $\mathrm{LiBH}_{4}$ and $\mathrm{FeCl}_{3}$ in ether at $228 \mathrm{~K}$ [130]. After the evaporation of the solvent, the filtrate was consistent with $\mathrm{Fe}\left(\mathrm{BH}_{4}\right)_{2}$, and the reduction of $\mathrm{Fe}(\mathrm{III})$ to $\mathrm{Fe}$ (II) was proposed [130]:

$$
3 \mathrm{LiBH}_{4}+\mathrm{FeCl}_{3} \rightarrow \mathrm{Fe}\left(\mathrm{BH}_{4}\right)_{2}+\frac{1}{2} \mathrm{H}_{2}+\frac{1}{2} \mathrm{~B}_{2} \mathrm{H}_{6}+3 \mathrm{LiCl}
$$

However, reaction (46) was not easily reproducible. The competing reaction of the reduction of $\mathrm{Fe}(\mathrm{III})$ to $\mathrm{Fe}(\mathrm{II})$, consuming $1 \mathrm{~mol}$ of $\mathrm{LiBH}_{4}$, was proposed to occur:

$$
\mathrm{LiBH}_{4}+\mathrm{FeCl}_{3} \rightarrow \mathrm{FeCl}_{2}+2 \mathrm{H}_{2}+\mathrm{B}+\mathrm{LiCl}
$$

$\mathrm{Fe}\left(\mathrm{BH}_{4}\right)_{2}$ was reported to decompose upon heating between $263 \mathrm{~K}$ and $273 \mathrm{~K}$; possible decomposition reactions are [130]:

$$
\begin{gathered}
\mathrm{Fe}\left(\mathrm{BH}_{4}\right)_{2} \rightarrow \mathrm{Fe}+\mathrm{H}_{2}+\mathrm{B}_{2} \mathrm{H}_{6} \\
\mathrm{Fe}\left(\mathrm{BH}_{4}\right)_{2} \rightarrow \mathrm{Fe}+2 \mathrm{~B}+4 \mathrm{H}_{2}
\end{gathered}
$$

In turn, Varin et al. mixed $2 \mathrm{LiBH}_{4}+\mathrm{FeCl}_{2}$ by means of milling in "soft conditions" (2-30 min at room temperature, under ultra-high purity $\mathrm{H}_{2}$ atmosphere and magneto ballmilling) [131,132]; infrared spectroscopy and X-ray diffraction results indicated the formation of a disordered $\mathrm{Fe}\left(\mathrm{BH}_{4}\right)_{2}$ that can decompose easily [131,132]. Recently, $\mathrm{Rb}{ }_{3} \mathrm{Fe}\left(\mathrm{BH}_{4}\right)_{5}$ and $\mathrm{Cs}_{3} \mathrm{Fe}\left(\mathrm{BH}_{4}\right)_{5}$ were produced by mechanical milling (Equation (28), $\mathrm{M}^{\prime}=\mathrm{Fe}$ ), and they crystalized in tetragonal I4/mcm [24]. The cell parameters of $\mathrm{Rb}_{3} \mathrm{Fe}\left(\mathrm{BH}_{4}\right)$ are a $=9.171$ (4) $\AA$, and $\mathrm{c}=15.833(6) \AA$, while the cell size of $\mathrm{Cs}_{3} \mathrm{Fe}\left(\mathrm{BH}_{4}\right)_{5}$ involves $\mathrm{a}=9.619(11) \AA$, and $\mathrm{c}=16.014(19) \AA$ [24].

To the best of our knowledge, no reports on ruthenium and osmium borohydrides have been published. 


\subsection{Group 9: Cobalt, Rhodium, and Iridium}

In 1956, Stewart and Scheaffer indicated that the reaction of $\mathrm{CoBr}_{2}$ and $\mathrm{LiBH}_{4}$ in ether at liquid nitrogen temperature produced a greyish-white precipitate. This precipitate was presumed to be cobalt borohydride; this material turned black (decomposed) in a few minutes when warmed to room temperature, accompanied by the release of hydrogen and the formation of $\mathrm{LiBr}$ and $\mathrm{CoB}_{2}$ [133]. No characterization of the greyish-white precipitate was reported. Recently, a DFT screening of ternary alkali-transition metal borohydrides indicated that $\mathbf{K C o}\left(\mathbf{B H}_{4}\right)_{3}$ and $\mathrm{NaCo}\left(\mathbf{B H}_{4}\right)_{3}$ would be more stable than $\mathbf{C o}\left(\mathbf{B H}_{4}\right)_{2}$. Both binary Co-borohydrides were remarked as promising materials [101].

To the best of our knowledge, no reports on homoleptic rhodium and iridium borohydrides have been published.

\subsection{Group 10: Nickel, Palladium, and Platinum}

To the best of our knowledge, no reports on homoleptic borohydrides of nickel, palladium, and platinum have been published. However, heteroleptic (with chelates type-ligands) Ni-borohydrides are stable and can be used as catalysts [134].

\subsection{Group 11: Copper, Silver, and Gold}

Essentially, no experimental advances of the group 11 borohydrides have been reported since the 1960s. $\mathbf{C u B H}_{4}$ was first reported by Wiberg; this material was produced by the metathesis reaction between $\mathrm{CuCl}$ and $\mathrm{LiBH}_{4}$ in a THF-ether (1:1) solution at $253 \mathrm{~K}$ [135]. However, $\mathrm{CuBH}_{4}$ decomposes in solution at $261-273 \mathrm{~K}$, producing $\mathrm{CuH}, \mathrm{B}, \mathrm{B}_{3} \mathrm{H}_{6}$, and $\mathrm{H}_{2}[135,136]$. An alternative is the use of $\mathrm{CuCl}_{2}$ in ether at 228K [136]:

$$
\mathrm{CuCl}_{2}+2 \mathrm{LiBH}_{4} \rightarrow \mathrm{CuBH}_{4}+\frac{1}{2} \mathrm{~B}_{2} \mathrm{H}_{6}+\frac{1}{2} \mathrm{H}_{2}+2 \mathrm{LiCl}
$$

$\mathrm{AgBH}_{4}$ can be produced by the following reaction in ether at $193 \mathrm{~K}$ [137]:

$$
\mathrm{AgClO}_{4}+\mathrm{LiBH}_{4} \rightarrow \mathrm{AgBH}_{4}+\mathrm{LiClO}_{4}
$$

$\mathrm{AgBH}_{4}$ decomposed at $243 \mathrm{~K}$ to produce $\mathrm{Ag}, \mathrm{H}_{2}$, and $\mathrm{BH}_{3}$; Wiberg proposed that $\mathrm{Ag}$ can catalyze the decomposition of $\mathrm{BH}_{3}$ to $\mathrm{B}$ and $\mathrm{H}_{2}$ [137].

$\mathrm{AuBH}_{4}$ was proposed to be unstable by Wiberg, i.e., it will not form even at low temperature [138], but it was mentioned that $\mathrm{Au}\left(\mathrm{BH}_{4}\right)_{3}$ could be prepared by the reaction between $\mathrm{AuCl}_{3}$ and $\mathrm{LiBH}_{4}$ in ether at $153 \mathrm{~K}$ [139] (and ref. 39 within), but that it decomposed upon an increase in temperature. Unfortunately, no other references to $\mathrm{Au}\left(\mathrm{BH}_{4}\right)_{3}$ have been located. Theoretical calculations supported the statement of Wiberg; $\mathrm{AuBH}_{4}$ is not stable, while $\mathrm{CuBH}_{4}$ and $\mathrm{AgBH}_{4}$ would be stable with a rapid exchange of the tridentate and bidentate coordination of the $\left[\mathrm{BH}_{4}\right]^{-1}$ ion [139].

\subsection{Group 12: Zinc, Cadmium, and Mercury}

$\mathbf{Z n}\left(\mathbf{B H}_{4}\right)_{\mathbf{2}}(8.48 \mathrm{wt}$ \% hydrogen content) was first reported by Wiberg and Henle in 1952 [140]. $\mathrm{Zn}\left(\mathrm{BH}_{4}\right)_{2}$ was prepared by the metathesis reaction between $\mathrm{ZnCl}_{2}$ and $\mathrm{LiBH}_{4}$ in ether at room temperature [140]. Since then, it has become clear that $\mathrm{Zn}\left(\mathrm{BH}_{4}\right)_{2}$ decomposes at about $358 \mathrm{~K}$ to produce $\mathrm{Zn}, \mathrm{B}$, and $\mathrm{H}_{2}$ [140]. Other synthesis routes in the organic solvent THF were published in 1969 [141]:

$$
\begin{gathered}
2 \mathrm{ZnBr}_{2}+2 \mathrm{KBH}_{4} \rightarrow \mathrm{Zn}\left(\mathrm{BH}_{4}\right)_{2}+\mathrm{K}_{2} \mathrm{ZnBr}_{4} \\
3 \mathrm{Zn}\left(\mathrm{OCH}_{3}\right)_{2}+4\left(\mathrm{BH}_{3}\right)_{2} \rightarrow 3 \mathrm{Zn}\left(\mathrm{BH}_{4}\right)_{2}+2 \mathrm{~B}\left(\mathrm{OCH}_{3}\right)_{3}
\end{gathered}
$$

Later, the preparation of $\mathrm{Zn}\left(\mathrm{BH}_{4}\right)_{2}$ by mechanical milling gained popularity. Beyond possible hydrogen storage applications, $\mathrm{Zn}\left(\mathrm{BH}_{4}\right)_{2}$ can be used in the reduction reaction of aldehydes and ketones [142] or as a source of $\mathrm{B}_{2} \mathrm{H}_{6}$ [143]. Choudhury et al. calculated that $\mathrm{Zn}\left(\mathrm{BH}_{4}\right)_{2}$ is an insulator material with a band gap of $3.529 \mathrm{eV}$ [144]. 
The crystal structure of $\mathrm{Zn}\left(\mathrm{BH}_{4}\right)_{2}$ has only been calculated theoretically, with some degree of controversy (Table 8). Nakamori et al. determined the $\mathrm{Zn}\left(\mathrm{BH}_{4}\right)_{2}$ crystal structure as triclinic P-1 (Figure 6) [30]. Choudhury et al., utilizing DFT calculations, determined that the orthorhombic $\mathrm{Pmc}_{1}\left(\mathrm{Mg}\left(\mathrm{BH}_{4}\right)_{2}\right.$ model $)$ structure is the most stable at $0 \mathrm{~K}$ and finite temperatures [144]. For their part, Doan Huan et al. calculated that a tetragonal $I 4_{1} 22$ $\mathrm{Zn}\left(\mathrm{BH}_{4}\right)_{2}$ structure would be the most stable [145]. In another DFT calculation, Aidhy and Wolverton indicated that the tetragonal $I 4 m 2$ and orthorhombic F222 structures of $\mathrm{Zn}\left(\mathrm{BH}_{4}\right)_{2}$ are near in energy, and have the lowest energies compared with other proposed structures [146]. The results of several stable structures point to the possible existence of polymorphism and low energies associated with transitions between them [145]. However, no experimental confirmation of the crystal structure of $\mathrm{Zn}\left(\mathrm{BH}_{4}\right)_{2}$ has been reported up to now. As in the case of Sc-borohydride, Zn-borohydride can be mistaken by a solvated product in wet synthesis, or as a bi-metallic borohydride in mechanically milled materials [147].

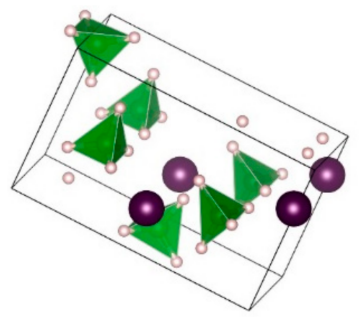

(a)

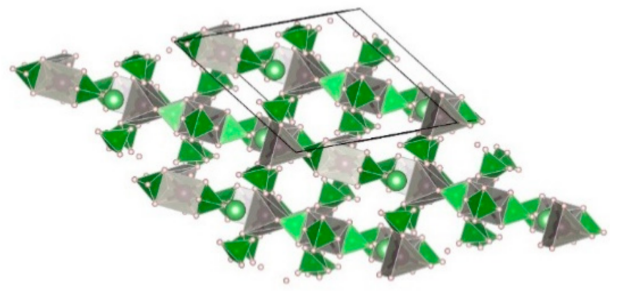

(b)

Figure 6. Crystal structure of $(\mathbf{a}) \mathrm{Zn}\left(\mathrm{BH}_{4}\right)_{2}$ and (b) $\mathrm{LiZn}\left(\mathrm{BH}_{4}\right)_{5}$. The structures become complex with the formation of double metal borohydrides. Detailed crystallographic information can be found in Table 8 .

$\mathrm{Zn}\left(\mathrm{BH}_{4}\right)_{2}$ (with $2 \mathrm{NaCl}$, from mechanical milling synthesis) melts at $358 \mathrm{~K}$, followed by the dehydrogenation reaction, which is registered 358-413 at K [148]. However, a considerable evolution of diborane was recorded. Thus, the dehydrogenation reaction was described as [148,149]:

$$
\mathrm{Zn}\left(\mathrm{BH}_{4}\right)_{2 \text { (solid) }} \rightarrow \mathrm{Zn}\left(\mathrm{BH}_{4}\right)_{2 \text { (liquid) }} \rightarrow \mathrm{Zn}+\mathrm{B}_{2} \mathrm{H}_{6}+\mathrm{H}_{2}
$$

Due to the formation of $\mathrm{B}_{2} \mathrm{H}_{6}$ at low temperature, $\mathrm{Zn}\left(\mathrm{BH}_{4}\right)_{2}$ can be used as a diborane source for other reactions. For example, Friedrich et al. used diborane from $\mathrm{Zn}\left(\mathrm{BH}_{4}\right)_{2}$ into $\mathrm{LiH}$ to test the regeneration of $\mathrm{LiBH}_{4}$ in soft $\mathrm{T}$ and $\mathrm{P}$ conditions [143]. Srinivasan et al. did not limit the formation of $\mathrm{B}_{2} \mathrm{H}_{6}$ in their discussion of results, and proposed the possible formation of $\mathrm{B}_{4} \mathrm{H}_{10}, \mathrm{~B}_{5} \mathrm{H}_{9}$, and $\mathrm{B}_{6} \mathrm{H}_{12}$ [150]. Srinivasan et al. demonstrated that $1.5 \mathrm{~mol} \%$ nano-Ni particles reduced the formation of diborane $[149,150]$. Other additives such as $\mathrm{TiCl}_{3}, \mathrm{TiF}_{3}$, nano-Fe, $\mathrm{Ti}$, nano-Ti [150], or carbon nanotubes [151] have demonstrated a small-to-moderate reduction in the decomposition temperature of $\mathrm{Zn}\left(\mathrm{BH}_{4}\right)_{2}$.

Interestingly, in $\mathrm{Mg}-\mathrm{Zn}\left(\mathrm{BH}_{4}\right)_{2}$ and $\mathrm{MgH}_{2}-\mathrm{Zn}\left(\mathrm{BH}_{4}\right)_{2}$ (materials composed of two layers, and 1:1 mixtures, respectively) doped with $\mathrm{Nb}_{2} \mathrm{O}_{5}$, a reaction between $\mathrm{Mg}-\mathrm{Zn}\left(\mathrm{BH}_{4}\right)_{2}$ and $\mathrm{MgH}_{2}-\mathrm{Zn}\left(\mathrm{BH}_{4}\right)_{2}$ occurred below 373K [152]. The authors proposed a reaction between $\mathrm{MgH}_{2}$ and $\mathrm{B}_{2} \mathrm{H}_{6}$ due to the appreciable reduction in diborane evolution and the change from the endothermic decomposition of $\mathrm{Zn}\left(\mathrm{BH}_{4}\right)_{2}$ to the exothermic decomposition of $\mathrm{Mg}-\mathrm{Zn}\left(\mathrm{BH}_{4}\right)_{2}$ and $\mathrm{MgH}_{2}-\mathrm{Zn}\left(\mathrm{BH}_{4}\right)_{2}$ [152]. These reactions have the characteristics of a reactive hydride composite. Conversely, $\mathrm{Zn}\left(\mathrm{BH}_{4}\right)_{2}$ was tried as an additive for $\mathrm{MgH}_{2}$, with no significant improvement for $\mathrm{MgH}_{2}$ dehydrogenation kinetics [153,154].

The formation enthalpy of $\mathrm{Zn}\left(\mathrm{BH}_{4}\right)_{2}$ was calculated as $-66.003 \mathrm{~kJ} / \mathrm{mol} \mathrm{H}_{2}$ at $300 \mathrm{~K}$, while the dehydrogenation enthalpy $\left(\mathrm{Zn}, \mathrm{B}\right.$, and $\mathrm{H}_{2}$ as the products) was calculated as $59.90 \mathrm{~kJ} / \mathrm{mol} \mathrm{H}_{2}$ at $0 \mathrm{~K}$ [144]. Such formation/dehydrogenation enthalpy is above the target of $20-50 \mathrm{~kJ} / \mathrm{mol} \mathrm{H}_{2}$. Thus, cation and anion substitution have been tried as strategies 
to tailor the formation or dehydrogenation thermodynamics. Bimetallic compounds have been reported in research on Zn-borohydrides as early as 1950-1969 [141]:

$$
\mathrm{ZnCl}_{2}+3 \mathrm{NaBH}_{4} \rightarrow \mathrm{NaZn}\left(\mathrm{BH}_{4}\right)_{3}+2 \mathrm{NaCl}
$$

$\operatorname{NaZn}\left(\mathbf{B H}_{4}\right)_{3}$ has a monoclinic space group symmetry $P 2_{1} / c$ (Table 8 ), where the $\mathrm{Zn}$ atoms present a distorted tetrahedral coordination, and metal atoms and $\left[\mathrm{BH}_{4}\right]^{-}$groups form a 3D framework [147]. It must be mentioned that different stoichiometric ratios can also produce $\mathbf{M Z n}\left(\mathbf{B H}_{4}\right)_{3}(\mathbf{M}=\mathbf{L i}, \mathbf{N a})$ (Table 8) [147,155]. A by-product, $\mathrm{M}_{2} \mathrm{ZnCl}_{4}$, plays an important role in dehydrogenation reaction [147].

$\mathrm{LiZn}_{2}\left(\mathbf{B H}_{4}\right)_{5}$ was produced by the reaction between $\mathrm{LiBH}_{4}\left(\right.$ or $\left.\mathrm{Li}^{11} \mathrm{BD}_{4}\right)$ and $\mathrm{ZnCl}_{2}$ utilizing mechanical milling (either cryogenic or room temperature milling) [156]. The $\mathrm{LiZn}_{2}\left(\mathrm{BH}_{4}\right)_{5}$ structure consists of two interpenetrating $3 \mathrm{D}$ frameworks of complex $\left[\mathrm{Zn}_{2}\left(\mathrm{BH}_{4}\right)_{5}\right]^{-1}$ ions and Li ions, with no bonds between the two different 3D frameworks, similar to some MOFs structures (Figure 6) [156].

$\mathbf{N a Z n}_{2}\left(\mathbf{B H}_{4}\right)_{5}$ can also be produced by mechanical ball milling, with the generalized reaction of Li- and Na- Zn-borohydrides being [147,155,157]:

$$
5 \mathrm{MBH}_{4}+2 \mathrm{ZnCl}_{2} \rightarrow \mathrm{MZn}_{2}\left(\mathrm{BH}_{4}\right)_{5}+4 \mathrm{MCl},(\mathrm{M}=\mathrm{Li} \text { or } \mathrm{Na})
$$

$\mathrm{MZn}_{2}\left(\mathrm{BH}_{4}\right)_{5}(\mathrm{M}=\mathrm{Li}$ or $\mathrm{Na})$ has a 3D framework structure, with two interpenetrating frameworks composed of an alkali-metal cation and a complex anion $\left[\mathrm{Zn}_{2}\left(\mathrm{BH}_{4}\right)_{5}\right]^{-}$, and built from two triangularly coordinated Zn atoms (Table 8) [147,155,157].

A first-principle study (DFT + PEGS (prototype electrostatic ground state)) indicated that $\mathrm{LiZn}\left(\mathrm{BH}_{4}\right)_{3}$ would have a triclinic $\mathrm{C} 1$ space group symmetry [146]. $\mathrm{LiZn}\left(\mathrm{BH}_{4}\right)_{3}$ is calculated to be more stable (about $-8 \mathrm{~kJ} / \mathrm{mol}$ cation) as compared to the parent borohydrides of $\mathrm{Li}$ and $\mathrm{Zn}$ [146], but unstable towards decomposition to $\mathrm{LiBH}_{4}$ and $\mathrm{LiZn}_{2}\left(\mathrm{BH}_{4}\right)_{5}$ (from DFT along with grand canonical linear programming method) [158]. In turn, $\mathrm{LiZn}_{2}\left(\mathrm{BH}_{4}\right)_{5}$ is calculated to decompose in a rather complex pathway [158]:

$$
\begin{gathered}
\mathrm{LiZn}_{2}\left(\mathrm{BH}_{4}\right)_{5} \rightarrow 2 \mathrm{Zn}+1 / 5 \mathrm{LiBH}_{4}+2 / 5 \mathrm{Li}_{2} \mathrm{~B}_{12} \mathrm{H}_{12}+36 / 5 \mathrm{H}_{2} \\
\rightarrow 2 \mathrm{Zn}+1 / 6 \mathrm{LiH}+5 / 12 \mathrm{Li}_{2} \mathrm{~B}_{12} \mathrm{H}_{12}+89 / 12 \mathrm{H}_{2} \\
\rightarrow 11 / 6 \mathrm{Zn}+1 / 6 \mathrm{LiZn}+5 / 12 \mathrm{Li}_{2} \mathrm{~B}_{12} \mathrm{H}_{12}+15 / 2 \mathrm{H}_{2} \\
\rightarrow \mathrm{Zn}+5 \mathrm{~B}+\mathrm{LiZn}+10 \mathrm{H}_{2}
\end{gathered}
$$

Ravnsbæk et al. agreed about the complex nature (coupled reactions) of dehydrogenation reactions and summarized them as [147]:

$2 \mathrm{MZn}_{2}\left(\mathrm{BH}_{4}\right)_{3}+\mathrm{M}_{2} \mathrm{ZnCl}_{4} \rightarrow 5 \mathrm{Zn}+4 \mathrm{MCl}+3 \mathrm{~B}_{2} \mathrm{H}_{6}+3 \mathrm{H}_{2} \mathrm{M}=\mathrm{Li}($ at $400 \mathrm{~K}), \mathrm{Na}($ at $368 \mathrm{~K}$ )

The same type of DFT + PEGS calculations on the analogous Na-Zn borohydrides indicated that $\mathrm{NaZn}\left(\mathrm{BH}_{4}\right)_{3}$ is unstable towards the decomposition of $\mathrm{Na}$ and $\mathrm{Zn}$-borohydrides, while $\mathrm{NaZn}_{2}\left(\mathrm{BH}_{4}\right)_{5}$ would be more stable than the parent borohydrides [146]. Xia et al. suppressed the production of diborane by infiltrating $\mathrm{NaZn}\left(\mathrm{BH}_{4}\right)_{3}$ in SBA-15 (prepared by wet-ball milling, dissolution in THF, infiltration, and drying) [159]. Additionally, a slight reduction in the dehydrogenation peak temperature was observed in the infiltrated material compared to the pure material ( $385 \mathrm{~K}$ versus $393 \mathrm{~K}$, respectively) [159]. Under those circumstances, the decomposition of $\mathrm{NaZn}\left(\mathrm{BH}_{4}\right)_{3}$ produced $\mathrm{NaBH}_{4}, \mathrm{Zn}, \mathrm{B}$, and $\mathrm{H}_{2}$ [159]. 
Table 8. Crystal structures of Zn-borohydrides.

\begin{tabular}{|c|c|c|c|}
\hline $\begin{array}{l}\text { Material and Hydrogen } \\
\text { Content [wt.\%] }\end{array}$ & Structural Parameters $\left[\AA{ }^{\circ}\right]$ & Atomic Positions & References and Comments \\
\hline \multirow[t]{2}{*}{$\begin{array}{l}\mathrm{Zn}\left(\mathrm{BH}_{4}\right)_{2} \\
\quad 8.48\end{array}$} & $\begin{array}{l}\text { Space group: triclinic } P-1(2) \\
\mathrm{a}=6.877, \mathrm{~b}=5.440, \mathrm{c}=7.842 \\
\alpha=89.5, \beta=76.15, \gamma=89.98\end{array}$ & $\begin{array}{c}\text { Zn: } 0.2498,0.0001,0.9998 . \text { B1: } 0.0567 \\
0.8903,0.7939 . \text { B2: } 0.5497,0.1754,0.8166 . \\
\text { H1: } 0.0997,0.8534,0.6382 . \text { H2: } 0.5892 \\
\text { 0.2640, } 0.6710 . \text { H3: } 0.1789,0.7718,0.8612 . \\
\text { H4: } 0.3316,0.7331,0.0999 . \text { H5: } 0.1031 \\
\text { 0.2267, } 0.1397 . \text { H6: } 0.3863,0.2679,0.9011 \\
\text { H7: } 0.0498,0.1135,0.8210 . \text { H8: } 0.4481 \\
0.0506,0.1928\end{array}$ & Theoretical [30] \\
\hline & $\begin{array}{l}\text { Space group: orthorhombic } P m c 2_{1} \\
\qquad \begin{array}{c}\text { (26) } \\
\mathrm{a}=4.118, \mathrm{~b}=4.864, \mathrm{c}=7.916 \\
\alpha=\beta=\gamma=90\end{array}\end{array}$ & $\begin{array}{c}\text { Zn: 0, 0.28459, 0.0089. B1: 0.5, -0.06481, } \\
\text { 0.4706. B2: 0,-0.46194, 0.24842. H1: 0.5 } \\
\text {-0.30735, 0.42745. H2: 0.27449,-0.0050, } \\
\text {-0.42983. H3: 0, 0.39706, 0.37973. H4: 0, } \\
0.21066,-0.24017 . \text { H5: 0.25820, }-0.48360 \\
\quad-0.32151 . \text { H6: } 0.5,0.08396,0.3488\end{array}$ & Optimized structure [144] \\
\hline $\begin{array}{c}\mathrm{LiZn}\left(\mathrm{BH}_{4}\right)_{3} \\
10.35\end{array}$ & $\begin{array}{c}\text { Space group: monoclinic } P 2_{1} / c(14) \\
\mathrm{a}=10.59, \mathrm{~b}=14.74, \mathrm{c}=8.66 \\
\alpha=\gamma=90, \beta=111.056\end{array}$ & 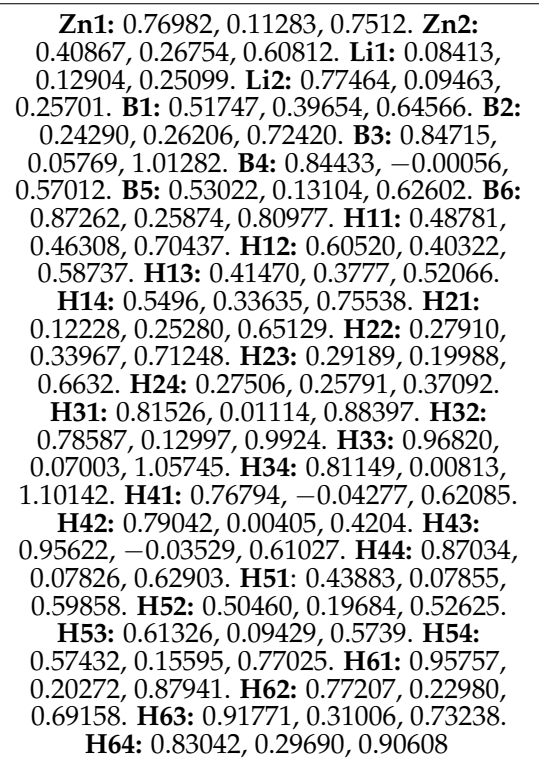 & DFT optimization [155] \\
\hline $\begin{array}{c}\mathrm{LiZn}_{2}\left(\mathrm{BD}_{4}\right)_{5} \\
9.51(\text { calculated as } \mathrm{H})\end{array}$ & 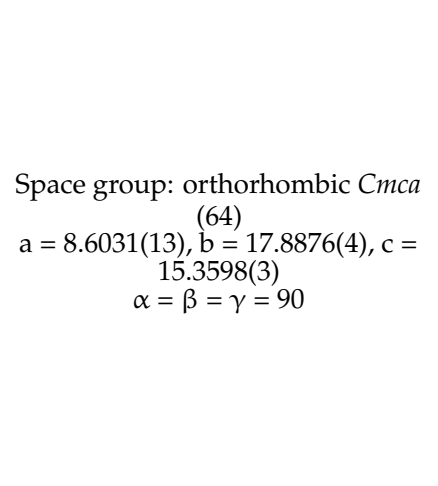 & $\begin{array}{c}\text { Zn1: 0, 0.6440(10), 0.7665(11). Zn2: } 0, \\
\text { 0.4252(12), 0.6300(16). Li1: 0, 0.138(6), } \\
\text { 0.434(6). B1: 0, 0.2580(4), 0.3166(5). D11: } 0, \\
\text { 0.1912(4), 0.3101(17). D12: 0, 0.2807(10), } \\
\text { 0.3903(5). D13: 0.1153(7), 0.2798(7), 0. } \\
\text { 2804(7). B2: 0, 0.3513(4), 0.0903(5). D21: } 0, \\
\text { 0.2971(5), 0.0442(8). D22: 0, 0.4090(5), } \\
\text { 0.0505(9). D23: 0.1136(7), 0.3488(10), } \\
\text { 0.1355(5). B3: 0, 0.5320(4), 0.7016(4). D31: } \\
\text { 0, 0.4746(5), 0.7421(9). D32: } 0,0.5264(14), \\
\text { 0.6238(5). D33: 0.1145(7), } 0.5662(5), \\
\text { 0.7223(9). B4: } 0.2284(8), 0.3825(4), \\
\text { 0.5882(4). D41: } 0.1551(14), 0.4234(6), \\
\text { 0.5415(7). D42: } 0.3368(10), 0.4186(7), \\
0.6142(11) . \text { D43: } 0.1591(14), 0.3629(10), \\
0.6520(6) . \text { D44: } 0.2550(19), 0.3297(5), \\
0.5424(8)\end{array}$ & $295 \mathrm{~K},{ }^{11} \mathrm{~B}[156]$ \\
\hline $\begin{array}{c}\mathrm{NaZn}\left(\mathrm{BH}_{4}\right)_{3} \\
9.10\end{array}$ & $\begin{array}{l}\text { Space group: triclinic } \mathrm{P} 1(1) \\
\mathrm{a}=7.125, \mathrm{~b}=7.246, \mathrm{c}=4.688 \\
\alpha=99.254 \\
\beta=91.097 \\
\gamma=71.422\end{array}$ & 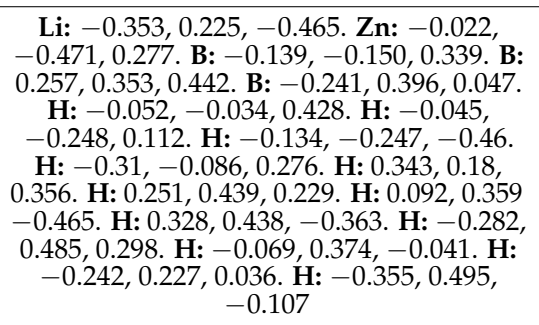 & $\begin{array}{c}\text { PEGS + DFT calculations } \\
{[146]}\end{array}$ \\
\hline
\end{tabular}


Table 8. Cont.

\begin{tabular}{|c|c|c|c|}
\hline $\begin{array}{l}\text { Material and Hydrogen } \\
\text { Content [wt.\%] }\end{array}$ & Structural Parameters $\left[\AA \AA^{\circ}\right]$ & Atomic Positions & References and Comments \\
\hline $\begin{array}{c}\mathrm{NaZn}_{2}\left(\mathrm{BH}_{4}\right)_{5} \\
8.84\end{array}$ & $\begin{array}{l}\text { Space group: monoclinic } P 2_{1} / c(14) \\
\quad \mathrm{a}=9.397(2), \mathrm{b}=16.635(3) \\
\quad \mathrm{c}=9.1359(16) \\
\alpha=\gamma=90, \beta=112.658(19)\end{array}$ & 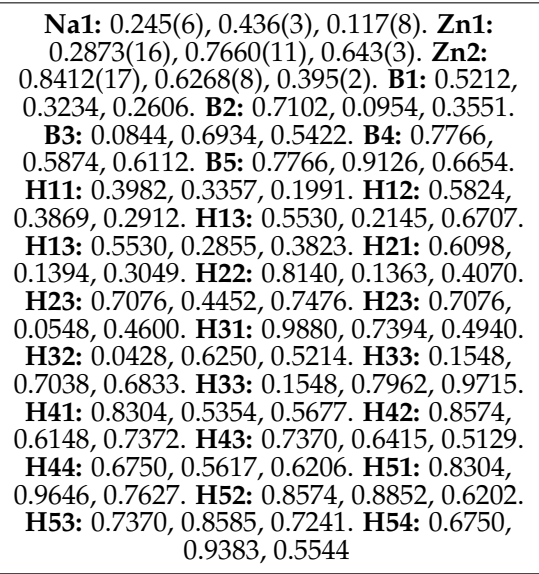 & [147] \\
\hline $\begin{array}{l}\mathrm{KZn}\left(\mathrm{BH}_{4}\right)_{3} \\
8.12\end{array}$ & $\begin{array}{l}\text { Space group: trigonal R3 (146) } \\
\mathrm{a}=\mathrm{b}=7.6291(8), \mathrm{c}=10.977(2) \alpha= \\
\gamma=90, \beta=120\end{array}$ & $\begin{array}{c}\text { K: } 0,0,0.49936 . \text { Zn: 0, 0, 0.00309. B: } \\
\text { 0.31006, 0.05088, 0.01153. H1: 0.19196, } \\
\text { 0.98384, 0.10009. H2: 0.44232, 0.21786, } \\
\text { 0.03989. H3: } 0.36275,0.92929,0.98755 . \text { H4: } \\
0.22942,0.06605,0.91529\end{array}$ & $\begin{array}{c}\text { Atomic parameters at } T=100 \\
\mathrm{~K} \\
{[160]}\end{array}$ \\
\hline $\begin{array}{c}\mathrm{Li}_{3} \mathrm{MgZn}_{5}\left(\mathrm{BH}_{4}\right)_{15} \\
10.17\end{array}$ & $\begin{array}{l}\text { Space group: hexagonal } P 6_{3} / \mathrm{mcm} \\
\qquad \begin{array}{c}\text { (193) } \\
\mathrm{a}=\mathrm{b}=15.371(3), \mathrm{c}=8.586(2) \\
\alpha=\gamma=90, \beta=120\end{array}\end{array}$ & $\begin{array}{c}\text { Zn1: } 1 / 3,2 / 3, \frac{1}{4} . \text { Zn2: } 0.2832(5), 0, \frac{1}{4} . \\
\text { Li/Mg: 0.598(1), 0, } \frac{1}{4} . \text { Li: 0, 0, 0. B1: } \\
\text { 0.131(1), 0, } \frac{1}{4} . \text { H11: 0.089(2), 0, 0.358(2). } \\
\text { H12: 0.139(2), -0.069(2), } \frac{1}{4} . \text { B2: 0.338(1), 0, } \\
\text { 0.004(2). H21: 0.302(2), 0, -0.111(2). H22: } \\
\text { 0.410(2), 0, - 0.019(2). H23: 0.285(2), } \\
-0.069(2), 0.073(2) . \text { B3: 0.5286(6), 0.346(2), } \\
\frac{1}{4} . \text { H31: 0.447(2), 0.286(2), } \frac{1}{4} . \text { H32: } 0.535(2), \\
0.423(2), \frac{1}{4} . \text { H33: } 0.566(2), 0.338(2), 0.143(2)\end{array}$ & $\begin{array}{c}\text { At RT. } \\
\text { Occupation of the } \mathrm{Li} / \mathrm{Mg} \text { site } \\
\text { Li: occ }=0.66(2), \mathrm{Mg}:(1-\mathrm{occ}) \\
=0.34(2) \\
\text { Occupation of the Li site Li: } \\
3^{*} \text { occ }-1=1 \\
{[129]}\end{array}$ \\
\hline
\end{tabular}

$\mathbf{K Z n}\left(\mathbf{B H}_{4}\right)_{3}$ was prepared by the ball-milled assisted reaction between $\mathrm{ZnCl}_{2}$ and $\mathrm{KBH}_{4}$ [160]:

$$
\mathrm{ZnCl}_{2}+3 \mathrm{KBH}_{4} \rightarrow \mathrm{KZn}\left(\mathrm{BH}_{4}\right)_{3}+2 \mathrm{KCl}
$$

Then, a side-reaction might also occur:

$$
\mathrm{ZnCl}_{2}+2 \mathrm{KCl} \rightarrow \mathrm{K}_{2} \mathrm{ZnCl}_{4}
$$

In Equation (63), a partial substitution of $\mathrm{Cl}^{-}$by $\left[\mathrm{BH}_{4}\right]^{-1}\left(\mathrm{~K}_{2} \mathrm{ZnCl}_{4-\mathrm{x}}\left(\mathrm{BH}_{4}\right)_{\mathrm{x}}\right)$ was registered and linked to the dehydrogenation reaction [160].

$\mathrm{KZn}\left(\mathrm{BH}_{4}\right)_{3}$ presents a trigonal space group symmetry $R 3$ (Table 8); the $\mathrm{Zn}$ atom is coordinated with three $\left[\mathrm{BH}_{4}\right]^{-1}$ groups in a triangular planar configuration, suggesting the existence of an anionic complex $\left[\mathrm{Zn}\left(\mathrm{BH}_{4}\right)_{3}\right]^{-1}$ located inside a rhombohedron of $\mathrm{K}$ atoms [160].

$\mathrm{KZn}\left(\mathrm{BH}_{4}\right)_{3}$ decomposes at $\sim 385 \mathrm{~K}$ to produce a gas mixture of $\mathrm{H}_{2}$ and diborane, and another double cation borohydride [160]:

$$
2 \mathrm{KZn}\left(\mathrm{BH}_{4}\right)_{3} \rightarrow \mathrm{K}_{2} \mathrm{Zn}\left(\mathrm{BH}_{4}\right)_{4}+\mathrm{Zn}+\mathrm{B}_{2} \mathrm{H}_{6}+\mathrm{H}_{2}
$$

Further heating leads to multistep dehydrogenation reactions, involving an exchange of $\mathrm{Cl}^{-}$and $\left[\mathrm{BH}_{4}\right]^{-1}$ ions. For $\mathrm{K}_{2} \mathrm{ZnCl}_{4-\mathrm{x}}\left(\mathrm{BH}_{4}\right)_{\mathrm{x}}$, an increase in $\left[\mathrm{BH}_{4}\right]^{-1}$ content was registered, first at $\sim 385 \mathrm{~K}$ but, upon further heating, $\left[\mathrm{BH}_{4}\right]^{-1}$ content decreased [160].

In general, in the double cation $\mathrm{M}-\mathrm{Zn}$ - borohydrides $\left(\mathrm{MZn}\left(\mathrm{BH}_{4}\right)_{3}\right.$ and $\mathrm{M}_{2} \mathrm{Zn}\left(\mathrm{BH}_{4}\right)_{4}$, $\mathrm{M}=\mathrm{Li}$, $\mathrm{Na}$ and $\mathrm{K}$ ), their synthesis by ball-milling, and the dehydrogenation reactions present many similarities.

$\mathbf{M g}_{(1-\mathrm{x})} \mathbf{Z n}_{\mathbf{x}}\left(\mathbf{B H}_{4}\right)_{2}$ (solid solution) was prepared by the mechanical milling of $\mathrm{Mg}\left(\mathrm{BH}_{4}\right)_{2}$ and $\mathrm{ZnCl}_{2}$ at room and liquid- $\mathrm{N}_{2}$ temperatures [161,162]. Decomposition was reported to 
start at 373-398 K with the release of hydrogen and diborane [161,162]. Careful control of the milling conditions and stoichiometry are important for the successful formation of the solid solution $\mathrm{Mg}_{(1-\mathrm{x})} \mathrm{Zn}_{\mathrm{x}}\left(\mathrm{BH}_{4}\right)_{2}$, dehydrogenation temperature, and products [161,162]. Cryogenic ball-milling offered a slight advantage in the preferential release of hydrogen over diborane [162]. A periodic DFT study of $\mathrm{Mg}_{(1-\mathrm{x})} \mathrm{Zn}_{\mathrm{x}}\left(\mathrm{BH}_{4}\right)_{2}(\mathrm{x}=0.2-0.3)$ indicates an energetically favorable mixing of $\mathrm{Zn}$ and $\mathrm{Mg}$ borohydrides and a decomposition enthalpy of about $30 \mathrm{~kJ} / \mathrm{mol} \mathrm{H}_{2}$ [163]. The DFT studies were performed by systematically replacing $\mathrm{Mg}$ atoms with $\mathrm{Zn}$ atoms in the $\alpha-\mathrm{Mg}\left(\mathrm{BH}_{4}\right)_{2}$ structure (both metals present +2 oxidation state and similar ionic size, $r_{\mathrm{Mg}}=0.065 \mathrm{~nm}$ and $\left.r_{\mathrm{Zn}}=0.074 \mathrm{~nm}[146]\right) . \mathrm{Mg}_{0.8} \mathrm{Zn}_{0 \cdot 2}\left(\mathrm{BH}_{4}\right)_{2}$ was claimed to be a promising composition [163].

Trimetallic borohydrides $\mathbf{L i}_{3} \mathbf{M Z n}_{5}\left(\mathbf{B H}_{4}\right)_{15}, \mathbf{M}=\mathbf{M g}$, and $\mathbf{M n}$, were produced by mechanical milling [129], reactions (44) and (45). In both cases, the formation of $\mathrm{LiZn}_{2}\left(\mathrm{BH}_{4}\right)_{5}$ as a by-product was observed. $\mathrm{Li}_{3} \mathrm{MZn}_{5}\left(\mathrm{BH}_{4}\right)_{15}, \mathrm{M}=\mathrm{Mg}$ and $\mathrm{Mn}$, also crystalizes in a hexagonal $\mathrm{P}_{3} / \mathrm{mcm}$ structure that contains channels built up from face-sharing $\left(\mathrm{BH}_{4}\right)_{6}$ octahedra [129]. The $\mathrm{Li}_{3} \mathrm{MZn}_{5}\left(\mathrm{BH}_{4}\right)_{15}$ materials, $\mathrm{M}=\mathrm{Mg}$ and $\mathrm{Mn}$, are interesting as solid-state electrolytes, and their decomposition (at 368-393 K for $\mathrm{Mg}$, and $385 \mathrm{~K}$ for Mn) produces the related borohydrides $\mathrm{LiBH}_{4}, \mathrm{Mg}\left(\mathrm{BH}_{4}\right)_{2}, \mathrm{Mn}\left(\mathrm{BH}_{4}\right)_{2}$ and $\mathrm{LiZn}_{2}\left(\mathrm{BH}_{4}\right)_{5}$. These latter borohydrides decompose at higher temperatures [129].

Chlorine-substituted $\mathrm{Zn}$-borohydrides, such as $\mathrm{LiZn}\left(\mathrm{BH}_{4}\right)_{2} \mathrm{Cl}$ and $\mathrm{Zn}\left(\mathrm{BH}_{4}\right) \mathrm{Cl}$, were observed as early as 1952 , with the latter compound decomposing at $393 \mathrm{~K}$ to produce $\mathrm{ZnCl}_{2}$, metallic $\mathrm{Zn}, \mathrm{B}$, and $\mathrm{H}_{2}$ [140]. $\mathrm{KZn}\left(\mathrm{BH}_{4}\right) \mathrm{Cl}_{2}$ was reported in 2011, and it decomposes at about $383 \mathrm{~K}$ to produce $\mathrm{K}_{2} \mathrm{ZnCl}_{4}$, metallic $\mathrm{Zn}$, boranes $\left(\left(\mathrm{BH}_{3}\right)_{\mathrm{n}}\right)$, and $\mathrm{H}_{2}$ [164].

$\mathbf{C d}\left(\mathbf{B H}_{4}\right)_{2}$ was first reported in 1952 by Wiberg et al. [165]. At the time, cadmium borohydride was produced in ether:

$$
\mathrm{CdCl}_{2}+2 \mathrm{LiBH}_{4} \rightarrow \mathrm{Cd}\left(\mathrm{BH}_{4}\right)_{2}+2 \mathrm{LiCl}
$$

In ether, $\mathrm{Cd}\left(\mathrm{BH}_{4}\right)_{2}$ can also be obtained as [166]:

$$
3 \mathrm{Cd}\left(\mathrm{OCH}_{3}\right)_{2}+4 \mathrm{~B}_{2} \mathrm{H}_{6} \rightarrow 3 \mathrm{Cd}\left(\mathrm{BH}_{4}\right)_{2}+2 \mathrm{~B}\left(\mathrm{OCH}_{3}\right)_{3}
$$

Later, in 2013, the reaction (65) without solvents was reported, i.e., ball milling synthesis $[167,168]$. Two polymorphs were identified: $\alpha-\mathrm{Cd}\left(\mathrm{BH}_{4}\right)_{2}$ and $\beta-\mathrm{Cd}\left(\mathrm{BH}_{4}\right)_{2}[167,168]$. The temperature of the polymorph transition was located at $328 \mathrm{~K}$ [167]. The formation of the polymorphs demonstrated a dependency on the milling temperature: the material prepared by cooling the milling vial (with liquid nitrogen) was mainly $\alpha-\mathrm{Cd}\left(\mathrm{BH}_{4}\right)_{2}$, while room temperature milling was associated with the formation of $\beta-\mathrm{Cd}\left(\mathrm{BH}_{4}\right)_{2}$ [168]. However, one side reaction was observed in the solid-state preparation reaction that reduced the quantity of $\mathrm{Cd}\left(\mathrm{BH}_{4}\right)_{2}$ formation [168]:

$$
\mathrm{LiBH}_{4}+\mathrm{CdCl}_{2} \rightarrow 0.5 \mathrm{Cd}\left(\mathrm{BH}_{4}\right)_{2}+0.5 \mathrm{Li}_{2} \mathrm{CdCl}_{4}
$$

The decomposition of $\mathrm{Cd}\left(\mathrm{BH}_{4}\right)_{2}$ was observed at room temperature [165], and even at lower temperatures [169]. Thus, cadmium borohydride is an unstable material. In a more detailed study, $\mathrm{Cd}\left(\mathrm{BH}_{4}\right)_{2}$ decomposed at $348 \mathrm{~K}$ with fast kinetics and produced $\mathrm{B}_{2} \mathrm{H}_{6}$ and $\mathrm{H}_{2}$ in a mole ratio of 1:1 [168]:

$$
\mathrm{Cd}\left(\mathrm{BH}_{4}\right)_{2} \rightarrow \mathrm{Cd}+\mathrm{B}_{2} \mathrm{H}_{6}+\mathrm{H}_{2}
$$

The formation of cation- and anion-substituted $\mathrm{Cd}\left(\mathrm{BH}_{4}\right)_{2}$ has been observed since the first reports [165] in organic solvents, such as ether or DMF (dimetylformamide) [170]:

$$
\begin{aligned}
& \mathrm{CdCl}_{2}+2 \mathrm{LiBH}_{4} \rightarrow \mathrm{LiCdCl}\left(\mathrm{BH}_{4}\right)_{2}+\mathrm{LiCl} \\
& \mathrm{CdCl}_{2}+3 \mathrm{LiBH}_{4} \rightarrow \mathrm{LiCd}\left(\mathrm{BH}_{4}\right)_{3}+2 \mathrm{LiCl}
\end{aligned}
$$


Reactions (65) and (69) in ether, and particularly reaction (70), can also occur in the systems $\mathrm{MBH}_{4} / \mathrm{CdX} 2, \mathrm{M}=\mathrm{Li}, \mathrm{Na}$ and $\mathrm{X}=\mathrm{Cl}, \mathrm{Br}, \mathrm{I}[166,170]$. The complex ions $\left[\mathrm{CdCl}\left(\mathrm{BH}_{4}\right)_{2}\right]^{-1}$ and $\left[\mathrm{Cd}\left(\mathrm{BH}_{4}\right)_{3}\right]^{-1}$ were observed during the solvent synthesis, and the formation of adducts was demonstrated [169-171]. The addition of an equivalent of $\mathrm{LiBH}_{4}$ to $\mathrm{LiCd}\left(\mathrm{BH}_{4}\right)_{3}$ in diglyme can produce a precipitate soluble in THF [171]:

$$
\mathrm{LiCd}\left(\mathrm{BH}_{4}\right)_{3}+\mathrm{LiBH}_{4} \leftrightarrow \mathrm{Li}_{2} \mathrm{Cd}\left(\mathrm{BH}_{4}\right)_{4}
$$

The $\mathbf{L i}_{2} \mathbf{C d}\left(\mathbf{B H}_{4}\right)_{4}$ precipitated as an adduct with four molecules of diglyme [171]. The ball milling of $\mathrm{MBH}_{4} / \mathrm{CdCl}_{2}, \mathrm{M}=\mathrm{Li}, \mathrm{Na}, \mathrm{K}$, in several molar ratios (1:1 to 4:1) only succeeded in producing $\mathbf{K C d}\left(\mathbf{B H}_{4}\right)_{3}$ and $\mathbf{K}_{2} \mathbf{C d}\left(\mathbf{B H}_{4}\right)_{4}$ [167]. The last product, $\mathrm{K}_{2} \mathrm{Cd}\left(\mathrm{BH}_{4}\right)_{4}$, is composed of tetrahedral $\left[\mathrm{Cd}\left(\mathrm{BH}_{4}\right)_{4}\right]^{-2}$ ions and eight-coordinated $\mathrm{K}^{+}$cations. $\mathrm{KCd}\left(\mathrm{BH}_{4}\right)_{3}$ has a structure that can be considered a framework intermediate between those of $\alpha$ $\mathrm{Cd}\left(\mathrm{BH}_{4}\right)_{2}$ and $\beta-\mathrm{Cd}\left(\mathrm{BH}_{4}\right)_{2}$ [167]. Decomposition of the $\mathrm{K}-\mathrm{Cd}$ borohydrides was proposed to be sequential [167]:

$$
\begin{gathered}
2 \mathrm{KCd}\left(\mathrm{BH}_{4}\right)_{3} \rightarrow \mathrm{K}_{2} \mathrm{Cd}\left(\mathrm{BH}_{4}\right)_{4}+\mathrm{Cd}+\mathrm{B}_{2} \mathrm{H}_{6}+\mathrm{H}_{2}, \sim 353 \mathrm{~K} \\
\mathrm{~K}_{2} \mathrm{Cd}\left(\mathrm{BH}_{4}\right)_{4} \rightarrow 2 \mathrm{KBH}_{4}+\mathrm{Cd}+\mathrm{B}_{2} \mathrm{H}_{6}+\mathrm{H}_{2}, \sim 358 \mathrm{~K}
\end{gathered}
$$

For the last element in group 12, i.e., $\mathrm{Hg}$, Nöth mentioned that the reaction of $\mathrm{LiBH}_{4}$ with $\mathrm{HgCl}_{2}$ at $195 \mathrm{~K}$ produced a reduction in $\mathrm{Hg}$ without the formation of mercury borohydride [166].

\section{Main-Group Borohydrides}

\subsection{Group 13: Aluminum, Gallium, Indium, and Thallium}

$\mathbf{A l}\left(\mathbf{B H}_{4}\right)_{3}$ is an "old" borohydride which has been known since 1939 [172,173]. Its standard formation enthalpy is $301.6 \mathrm{~kJ} / \mathrm{mol}$ liquid $\mathrm{Al}\left(\mathrm{BH}_{4}\right)_{3}$ [174]. It is a very hazardous and volatile liquid at room temperature (melting point $\sim 208 \mathrm{~K}$ ), with an average heat of vaporization of $29.9 \mathrm{~kJ} / \mathrm{mol}$ [173] that detonates on contact with air containing traces of moisture [175]. $\mathrm{Al}\left(\mathrm{BH}_{4}\right)_{3}$ can be produced by reactions (74) and (75) $[172,173,175]$, and recovered by proper condensing (cooling) of the volatile product:

$$
\begin{gathered}
\mathrm{Al}_{2}\left(\mathrm{CH}_{3}\right)_{6}+4 \mathrm{~B}_{2} \mathrm{H}_{6} \rightarrow 2 \mathrm{~B}\left(\mathrm{CH}_{3}\right)_{3}+2 \mathrm{Al}\left(\mathrm{BH}_{4}\right)_{3}, 178-353 \mathrm{~K} \\
\mathrm{AlX}_{3}+3 \mathrm{MBH}_{4} \rightarrow \mathrm{Al}\left(\mathrm{BH}_{4}\right)_{3} \uparrow+3 \mathrm{MX}, \mathrm{X}=\mathrm{Cl} \text { or } \mathrm{Br}, \mathrm{M}=\mathrm{Li}, \mathrm{Na} \text { or } \mathrm{K}
\end{gathered}
$$

$\mathrm{Al}\left(\mathrm{BH}_{4}\right)_{3}$ was used to prepare other borohydrides (Th, U, Hf, Ti, etc.) in the 1940s [72]. Many years later, the low temperature $\alpha$ - and $\beta-\mathrm{Al}\left(\mathrm{BH}_{4}\right)_{3}$ crystalline structures were discovered (Table 9) [176]: $\alpha-\mathrm{Al}\left(\mathrm{BH}_{4}\right)_{3}$ presents a monoclinic space group $C 2 / c$, while $\beta$ $\mathrm{Al}\left(\mathrm{BH}_{4}\right)_{3}$ presents an orthorhombic space group of $P n a 2_{1}$. Both polymorphs are composed of discrete molecular $\mathrm{Al}\left(\mathrm{BH}_{4}\right)_{3}$ units. The $\alpha$ - to $\beta-\mathrm{Al}\left(\mathrm{BH}_{4}\right)_{3}$ phase change occurs between 180 and $195 \mathrm{~K}$ [176]. In the gas phase, $\mathrm{Al}\left(\mathrm{BH}_{4}\right)_{3}$ presents a $D_{3 h}$ symmetry with a planar $\mathrm{Al}-\mathrm{B}_{3}$ skeleton and $\eta^{2}-\left[\mathrm{BH}_{4}\right]^{-1}$ ligands [176-180]. The heats of formation were calculated in 2006 by first principles, as $-132 \mathrm{~kJ} / \mathrm{mol}$ and $-131 \mathrm{~kJ} / \mathrm{mol}$ (without zero-point correction) for $\alpha$ - and $\beta-\mathrm{Al}\left(\mathrm{BH}_{4}\right)_{3}$, respectively [181]. The calculations also demonstrated the nonmetallic nature of $\alpha-\mathrm{Al}\left(\mathrm{BH}_{4}\right)_{3}$, with a calculated band gap of $6.0 \mathrm{eV}$ [181]. Decomposition of $\mathrm{Al}\left(\mathrm{BH}_{4}\right)_{3}$ was predicted to be a spontaneous process above approximately $400 \mathrm{~K}$, occurring with the release of $\mathrm{B}_{2} \mathrm{H}_{6}$ [70], but the experimentally observed decomposition occurred at room temperature $[172,173]$. In 2016, Harrison et al. proposed reducing diborane production, at least theoretically, by including a second cation, as in $\mathrm{Al}_{1-\mathrm{x}} \mathrm{Sc}_{\mathrm{x}}\left(\mathrm{BH}_{4}\right)_{3}$ [182].

Thermal stabilization was achieved by the formation of double cation borohydrides of $\mathrm{Al}$ with group 1 alkali metals, i.e., the formation of $\left[\mathrm{Al}\left(\mathrm{BH}_{4}\right)_{4}\right]^{-1}$ ions $[183,184]$. $\mathrm{MAl}\left(\mathrm{BH}_{4}\right)_{4}$, $\mathrm{M}=\mathrm{Li}, \mathrm{Na}, \mathrm{K}, \mathrm{Rb}$, and $\mathrm{Cs}$, can be produced by the following reaction [184]:

$$
\mathrm{Al}\left(\mathrm{BH}_{4}\right)_{3}+\mathrm{MBH}_{4} \rightarrow \mathrm{MAl}\left(\mathrm{BH}_{4}\right)_{4}
$$


Table 9. Crystal structures of Al-borohydrides.

\begin{tabular}{|c|c|c|c|}
\hline $\begin{array}{l}\text { Material and Hydrogen } \\
\text { Content [wt.\%] }\end{array}$ & Structural Parameters $\left[\AA \AA^{\circ}{ }^{\circ}\right]$ & Atomic Positions & References and Comments \\
\hline $\begin{array}{c}\alpha-\mathrm{Al}\left(\mathrm{BH}_{4}\right)_{3} \\
16.91\end{array}$ & $\begin{array}{l}\text { Space group: monoclinic } C 2 / c(15) \\
\quad \begin{array}{c}a=21.917(4), b=5.9860(12) \\
c=21.787(4) \\
\alpha=90, \beta=111.90(3), \gamma=90\end{array}\end{array}$ & 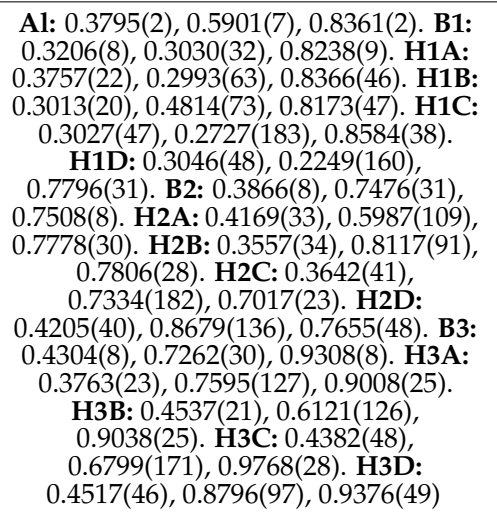 & $\begin{array}{c} \\
\text { CCDC ('Cambridge } \\
\text { Crystallographic Data Centre) } \\
\text { identification number 230830 }\end{array}$ \\
\hline $\begin{array}{l}\beta-\mathrm{Al}\left(\mathrm{BH}_{4}\right)_{3} \\
16.91\end{array}$ & $\begin{array}{l}\text { Space group: orthorhombic Pna2 } \\
\begin{array}{c}(33) \\
\mathrm{a}=18.021(3), \mathrm{b}=6.138(2), \mathrm{c}= \\
6.1987(14) \\
\alpha=\beta=\gamma=90\end{array}\end{array}$ & 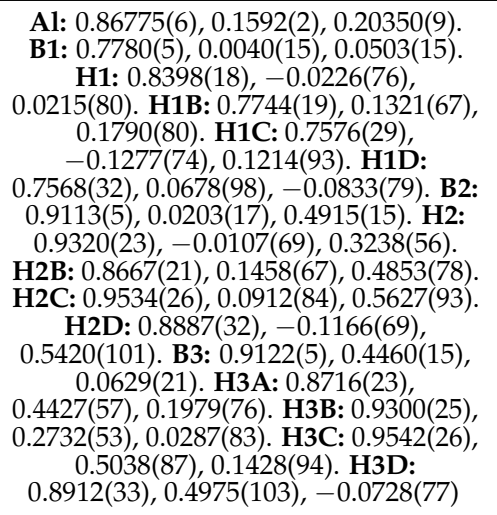 & $\begin{array}{c} \\
\text { CCDC (Cambridge } \\
\text { Crystallographic Data Centre) } \\
\text { identification number } 230829\end{array}$ \\
\hline $\begin{array}{c}\mathrm{Li}_{4} \mathrm{Al}_{3}\left(\mathrm{BH}_{4}\right)_{13} \\
17.37\end{array}$ & $\begin{array}{l}\text { Space group: cubic } P-43 n(218) \\
\begin{array}{c}\mathrm{a}=\mathrm{b}=\mathrm{c}=11.3640(3) \AA \\
\alpha=\beta=\gamma=90\end{array}\end{array}$ & $\begin{array}{c}\text { Li: } 0.1315(11), 0.1315(11), 0.1315(11) \\
\text { B1: } 0,0,0 . \text { H11: } 0.9424(5), 0.9424(5), \\
0.9424(5) . \text { Al: } \frac{1}{4}, \frac{1}{2}, 0 . \text { B2: } 0.1731(5), \\
0.6680(5), 0.4547(4) . \text { H21: } 0.1892(15) \\
0.6358(15), 0.3636(8) . \text { H22: } 0.1595(15) \\
0.7671(6), 0.4548(15) \text { H23: } 0.0876(10) \\
0.6266(14), 0.4893(15) . \text { H24: } 0.2463(11) \\
0.6455(15), 0.5176(12)\end{array}$ & $\begin{array}{c}\text { At } 100 \mathrm{~K} \\
\text { Rietveld refinement [186] }\end{array}$ \\
\hline $\begin{array}{l}\mathrm{KAl}\left(\mathrm{BH}_{4}\right)_{4} \\
\quad 12.85\end{array}$ & $\begin{array}{l}\text { Space group: orthorhombic Fddd } \\
\qquad \begin{array}{c}(70) \\
\mathrm{a}=9.7405(3), \mathrm{b}=12.4500(4), \mathrm{c}= \\
14.6975(4) \\
\alpha=\beta=\gamma=90\end{array}\end{array}$ & $\begin{array}{c}\text { K: } 0.125,0.125,0.125 . \text { Al: } 0.375,0.375 \\
\text { 0.375. B: } 0.7760(4), 0.6939(3), 0.7263(3) \\
\text { H1: } 0.6927(10), 0.7372(10), 0.6864(8) . \\
\text { H2: } 0.7559(12), 0.7164(11), 0.7984(5) . \\
\text { H3: } 0.7654(12), 0.6077(5), 0.7198(8) . \\
\text { H4: } 0.8767(8), 0.7204(8), 0.7007(8)\end{array}$ & [185] \\
\hline
\end{tabular}

Reaction (76) was obtained by transferring the liquid $\mathrm{Al}\left(\mathrm{BH}_{4}\right)_{3}$ into the vessel that contains solid $\mathrm{MBH}_{4}$, and further purification was achieved by evaporation of the newly formed aluminum borohydride [185]. $\mathbf{L i}_{4} \mathbf{A l}_{3}\left(\mathbf{B H}_{4}\right)_{13}$ was always produced as a side product of reaction (76) when using $\mathrm{LiBH}_{4}$ [184]. $\mathrm{Li}_{4} \mathrm{Al}_{3}\left(\mathrm{BH}_{4}\right)_{13}$ can be considered a decomposition product of $\mathrm{LiAl}\left(\mathrm{BH}_{4}\right)_{4}$ because, upon the heating of $\mathrm{LiAl}\left(\mathrm{BH}_{4}\right)_{4}$ at $333 \mathrm{~K}$, the following reaction occurs [184]:

$$
4 \mathrm{LiAl}\left(\mathrm{BH}_{4}\right)_{4} \rightarrow \mathrm{Li}_{4} \mathrm{Al}_{3}\left(\mathrm{BH}_{4}\right)_{13}+\mathrm{Al}\left(\mathrm{BH}_{4}\right)_{3}
$$

$\mathbf{L i}_{4} \mathbf{A l}_{3}\left(\mathbf{B H}_{4}\right)_{13}$ can also be produced by the following reaction (under ball-milling with careful temperature and pressure monitoring) [186]:

$$
3 \mathrm{AlCl}_{3}+13 \mathrm{LiBH}_{4} \rightarrow \mathrm{Li}_{4} \mathrm{Al}_{3}\left(\mathrm{BH}_{4}\right)_{13}+9 \mathrm{LiCl}
$$

The crystal structures of $\mathrm{LiAl}\left(\mathrm{BH}_{4}\right)_{4}$ and $\mathrm{Li}_{4} \mathrm{Al}_{3}\left(\mathrm{BH}_{4}\right)_{13}$ are monoclinic $P 2_{1} / \mathrm{c}$ and cubic $P-43 n$, respectively (Table 9) [184]. The crystal structure of $\mathrm{Li}_{4} \mathrm{Al}_{3}\left(\mathrm{BH}_{4}\right)_{13}$ is composed of 
the complex cation $\left[\left(\mathrm{BH}_{4}\right) \mathrm{Li}_{4}\right]^{+3}$ and the $\left[\mathrm{Al}\left(\mathrm{BH}_{4}\right)_{4}\right]^{-1}$ anion [186]. The decomposition of $\mathrm{Li}_{4} \mathrm{Al}_{3}\left(\mathrm{BH}_{4}\right)_{13}$ occurred at $363 \mathrm{~K}$, producing more $\mathrm{Al}\left(\mathrm{BH}_{4}\right)_{3}$ and $\mathrm{LiBH}_{4}[184,186,187]$.

$\mathrm{NaAl}\left(\mathrm{BH}_{4}\right)_{4}$ was briefly mentioned by Dovgaliuk et al.; this material crystallized in the monoclinic space group $\mathrm{C} 2 / \mathrm{c}$ and decomposed at $363 \mathrm{~K}$ to produce the parent $\mathrm{Na}$ and $\mathrm{Al}$ borohydrides [184]. $\mathbf{K A l}\left(\mathbf{B H}_{4}\right)_{4}$ can be produced by direct contact of $\mathrm{K}$ and $\mathrm{Al}$ borohydrides at room temperature $[185,188]$ :

$$
\mathrm{KBH}_{4(\mathrm{~s})}+\mathrm{Al}\left(\mathrm{BH}_{4}\right)_{3(\mathrm{l})} \rightarrow \mathrm{KAl}\left(\mathrm{BH}_{4}\right)_{4(\mathrm{~s})}
$$

Reaction (79) was reported to occur slowly for several days under high precautions due to the reactivity of $\mathrm{Al}\left(\mathrm{BH}_{4}\right)_{3}$ [188]. $\mathrm{KAl}\left(\mathrm{BH}_{4}\right)_{4}$ crystallized in the orthorhombic Fddd space group, where the $\left[\mathrm{Al}\left(\mathrm{BH}_{4}\right)_{4}\right]^{-1}$ anion forms distorted tetrahedra [185].

Thermal decomposition of $\mathrm{KAl}\left(\mathrm{BH}_{4}\right)_{4}$ begins at $427 \mathrm{~K}$, with a separation into the original borohydrides and an enthalpy of $36 \mathrm{~kJ} / \mathrm{mol}$ [188]. Then, the decomposition of $\mathrm{Al}\left(\mathrm{BH}_{4}\right)_{3}$ was proposed to occur as [188]:

$$
\begin{gathered}
\mathrm{Al}\left(\mathrm{BH}_{4}\right)_{3(\mathrm{~g})} \rightarrow \mathrm{AlH}\left(\mathrm{BH}_{4}\right)_{2(\mathrm{~s})}+0.5 \mathrm{~B}_{2} \mathrm{H}_{6(\mathrm{~g})} \\
\mathrm{AlH}\left(\mathrm{BH}_{4}\right)_{2(\mathrm{~s})} \rightarrow \mathrm{AlH}_{2}\left(\mathrm{BH}_{4}\right)_{(\mathrm{s})}+0.5 \mathrm{~B}_{2} \mathrm{H}_{6(\mathrm{~g})} \\
\mathrm{AlH}_{2}\left(\mathrm{BH}_{4}\right)_{(\mathrm{s})} \rightarrow \mathrm{Al}_{(\mathrm{s})}+0.5 \mathrm{~B}_{2} \mathrm{H}_{6(\mathrm{~g})}+1.5 \mathrm{H}_{2} \\
0.5 \mathrm{~B}_{2} \mathrm{H}_{6(\mathrm{~g})} \rightarrow(\mathrm{BH})_{n(\mathrm{~s})}+\mathrm{H}_{2}
\end{gathered}
$$

For their part, Dovgaliuk et al. proposed a one-step dehydrogenation of $\mathrm{KAl}\left(\mathrm{BH}_{4}\right)_{4}$ at 433 K (maximum DSC peak) [185]:

$$
2 \mathrm{KAl}\left(\mathrm{BH}_{4}\right)_{4} \rightarrow \mathrm{KBH}_{4}+\mathrm{KAl}_{2} \mathrm{~B}_{3}+2 \mathrm{~B}_{2} \mathrm{H}_{6}+8 \mathrm{H}_{2}
$$

Reaction (84) was proposed based on the combined results of several characterization techniques [185]. The decomposition product $\mathrm{KAl}_{2} \mathrm{~B}_{3}$ is an amorphous material [185]. Decomposition of $\mathrm{KBH}_{4}$ must occur at higher temperatures. No re-hydrogenation was achieved up to $10 \mathrm{MPa}$ hydrogen pressure and $593 \mathrm{~K} \mathrm{[185].}$

$\mathbf{R b A l}\left(\mathbf{B H}_{4}\right)_{4}$ (orthorhombic Fddd) and $\mathbf{C s A l}\left(\mathbf{B H}_{4}\right)_{4}$ (tetragonal I4 1 /amd) were also briefly mentioned by Dovgaliuk et al.; these materials decomposed at $433 \mathrm{~K}$ and $423 \mathrm{~K}$, respectively [184].

Homoleptic gallium borohydride does not exist. However, the related compounds, $\mathbf{G a H}\left(\mathbf{B H}_{4}\right)_{2}$ and $\mathbf{G a H}_{\mathbf{2}}\left(\mathbf{B H}_{4}\right)$, were reported in $[189,190]$. $\mathrm{GaH}\left(\mathrm{BH}_{4}\right)_{2}$ can be produced in the absence of solvent at $228 \mathrm{~K}$ with an excess of $\mathrm{LiBH}_{4}[189,191,192]$ :

$$
\mathrm{GaCl}_{3}+3 \mathrm{LiBH}_{4} \rightarrow \mathrm{GaH}\left(\mathrm{BH}_{4}\right)_{2}+3 \mathrm{LiCl}+\frac{1}{2} \mathrm{~B}_{2} \mathrm{H}_{6}, 228 \mathrm{~K}
$$

or

$$
\mathrm{HGaCl}_{2}+2 \mathrm{LiBH}_{4} \rightarrow \mathrm{GaH}\left(\mathrm{BH}_{4}\right)_{2}+2 \mathrm{LiCl}, 228 \mathrm{~K}
$$

These reactions are globally similar to the $\mathrm{GaH}_{2}\left(\mathrm{BH}_{4}\right)$ synthesis [190]:

$$
\frac{1}{2}\left(\mathrm{H}_{2} \mathrm{GaC} 1\right)_{2}+\mathrm{LiBH}_{4} \rightarrow \mathrm{GaH}_{2}\left(\mathrm{BH}_{4}\right)+\mathrm{LiCl}, 250 \mathrm{~K},
$$

$\mathrm{GaH}\left(\mathrm{BH}_{4}\right)_{2}$ is volatile (melting point at approximately $203 \mathrm{~K}$ and vapor pressure of 10 $\mathrm{mmHg}$ at $228 \mathrm{~K}$ [189]), unstable, and decomposes above $228 \mathrm{~K}$ [189]. $\mathrm{GaH}_{2}\left(\mathrm{BH}_{4}\right)$ is also unstable and decomposes upon heating [190]. Decomposition products of both compounds are $\mathrm{Ga}, \mathrm{H}_{2}$, and $\mathrm{B}_{2} \mathrm{H}_{6}[189,190]$.

$\operatorname{In}\left(\mathbf{B H}_{4}\right)_{3}$ was reported in 1957, and this borohydride was obtained by the reaction in ether at $228 \mathrm{~K}$ [193]:

$$
\mathrm{InR}_{3}+(3+3 / n) \mathrm{BH}_{3} \rightarrow \operatorname{In}\left(\mathrm{BH}_{4}\right)_{3}+(3 / n) \mathrm{BH}_{3-n} \mathrm{R}_{\mathrm{n}}, \mathrm{R}=\text { methyl }
$$


This reaction is slow (2 days). Another option (less efficient) is the following reaction in ether at $248 \mathrm{~K}$ [193]:

$$
\mathrm{InCl}_{3}+3 \mathrm{LiBH}_{4} \rightarrow \operatorname{In}\left(\mathrm{BH}_{4}\right)_{3}+3 \mathrm{LiCl}
$$

$\operatorname{In}\left(\mathrm{BH}_{4}\right)_{3}$ crystalized as $\operatorname{In}\left(\mathrm{BH}_{4}\right)_{3} \cdot 3 \mathrm{THF}$ at $233 \mathrm{~K}$ and as $\operatorname{In}\left(\mathrm{BH}_{4}\right)_{3} \cdot 2 \mathrm{THF}$ at $243 \mathrm{~K}$, and decomposed at $263 \mathrm{~K}$ to produce metallic indium, hydrogen, and borane [193].

$\mathrm{TlBH}_{4}$ was reported in 1957 [194]; no additional reports have been located. $\mathrm{TlBH}_{4}$ was synthesized by the reaction between thallium ethylate and lithium borohydride in ether at room temperature [194]:

$$
\mathrm{TlOR}+\mathrm{LiBH}_{4} \rightarrow \mathrm{TlBH}_{4}+\mathrm{LiOR}
$$

Purification of the $\mathrm{TlBH}_{4}$ was not possible, and decomposition of the whole mixture, $\mathrm{TlBH}_{4}+\mathrm{LiOR}$, was registered at 423 - $443 \mathrm{~K}$ [194]. The homoleptic borohydride of Tl(III) cannot be prepared, even at a low temperature; instead, $\mathrm{TlCl}\left(\mathrm{BH}_{4}\right)_{2}$ was produced at $163 \mathrm{~K}$ [195]:

$$
\mathrm{TlCl}_{3}+2 \mathrm{LiBH}_{4} \rightarrow \mathrm{TlCl}\left(\mathrm{BH}_{4}\right)_{2}+2 \mathrm{LiCl}
$$

$\mathrm{TlCl}\left(\mathrm{BH}_{4}\right)_{2}$ decomposed at $178 \mathrm{~K}$ producing hydrogen, borane, and $\mathrm{TlCl}$ [195].

\subsection{Group 14: Lead}

$\mathrm{CsPb}\left(\mathrm{BH}_{4}\right)_{3}$ and $\mathrm{CsPb}\left(\mathrm{BH}_{4}\right)_{2} \mathrm{Cl}$ were briefly described in a recent report [69]. $\mathrm{CsPb}\left(\mathrm{BH}_{4}\right)_{3}$ is a semiconducting borohydride with an experimental band gap of $\sim 1.5 \mathrm{eV}$ at $\mathrm{RT}$. $\mathrm{CsPb}\left(\mathrm{BH}_{4}\right)_{3}$ releases $4.3 \mathrm{wt} \%$. hydrogen at $360 \mathrm{~K}$ [69].

\section{Rare Earth Metal Borohydrides}

In 1959, a report described the reactions between $\mathrm{RE}\left(\mathrm{OCH}_{3}\right)_{3}, \mathrm{RE}=\mathrm{Y}, \mathrm{Sm}, \mathrm{Eu}, \mathrm{Gd}$, $\mathrm{Td}, \mathrm{Dy}, \mathrm{Ho}, \mathrm{Er}, \mathrm{Tm}, \mathrm{Yb}$, and $\mathrm{Lu}$, with diborane in THF [51]. The products were solvated borohydrides, $\mathrm{RE}\left(\mathrm{BH}_{4}\right)_{3}$. As stated in the introductory section, the synthesis of these borohydrides currently follows a new approach in the sense of combining mechanical milling with solvent extraction, solvent and reactant function of precursors, or the use of mixtures of solvents to extract products selectively. As the products are frequently solvated, the release of solvent molecules such as $\mathrm{S}\left(\mathrm{CH}_{3}\right)_{2}$ has been confirmed by TGA/DSC or in-situ diffraction characterization. However, some materials cannot be dried without decomposing. Additionally, the emission of some $\mathrm{B}_{2} \mathrm{H}_{6}$ is also observed during heating to temperatures close to those of solvent release. Besides decomposition, the release of $\mathrm{B}_{2} \mathrm{H}_{6}$ could be related to occluded impurities from the synthesis process. Stadie et al. demonstrated that the elimination of solvents and B-H impurities with supercritical $\mathrm{N}_{2}$ processing (roughly, exposing to liquid $\mathrm{N}_{2}$ at $110 \mathrm{~K}$ and $2 \mathrm{MPa}$ and degassing several times) practically eliminated $\mathrm{B}_{2} \mathrm{H}_{6}$ release from $\mathrm{Mg}\left(\mathrm{BH}_{4}\right)_{2}$ [196]. Another issue to be noticed is that the metathesis reaction between $\mathrm{RECl}_{3}$ and $\mathrm{LiBH}_{3}$ frequently leads to the formation of mixtures of $\mathrm{RE}\left(\mathrm{BH}_{4}\right)_{3}, \mathrm{LiRE}\left(\mathrm{BH}_{4}\right)_{4}$ and $\operatorname{LiRE}\left(\mathrm{BH}_{4}\right)_{3} \mathrm{Cl}$ [197]. The relative amount of these products might depend on synthesis conditions, such as the excess of reactants or milling time and temperature [198].

\subsection{Lanthanides}

$\mathbf{L a}\left(\mathbf{B H}_{4}\right)_{3}$ was produced by mechanical milling of anhydrous $\mathrm{LaCl}_{3}$ and $\mathrm{LiBH}_{4}$ using different milling times (1 to $48 \mathrm{~h}$ ) [199]. Zhang et al. indicated that a similar reaction with $\mathrm{LaF}_{3}$ was not as responsive as with $\mathrm{LaCl}_{3}$ [199]. The dehydrogenation of these mixtures indicated a multistep process; the main dehydrogenation event occurred at approximately $523 \mathrm{~K}$ for the $\mathrm{LaCl}_{3}$ precursor and $573 \mathrm{~K}$ for $\mathrm{LaF}_{3}$ [199]. The difference was explained by the formation of $\mathrm{La}\left(\mathrm{BH}_{4}\right)_{3}$ in the first case and the in-situ reaction between $\mathrm{LiBH}_{4}$ and $\mathrm{LaF}_{3}$ in the second case [199]. In both cases, the dehydrogenation products were $\mathrm{LaH}_{2}, \mathrm{LaB}_{6}, \mathrm{H}_{2}$, and $\mathrm{LiCl}$ or $\mathrm{LiF}$, respectively. Standard dehydrogenation enthalpies were estimated as 48.2 and $49.3 \mathrm{~kJ} / \mathrm{mol} \mathrm{H}_{2}$, respectively [199]. Partial hydrogen uptake of the dehydrogenated 
materials was observed (at $623 \mathrm{~K}$ or $723 \mathrm{~K}, 10 \mathrm{MPa}, 24 \mathrm{~h}$ ) [199]. Recently, pure $\mathrm{La}\left(\mathrm{BH}_{4}\right)_{3}$ was produced by the reaction of (pre-milled) $\mathrm{LaCl}_{3}$ and $\mathrm{LiBH}_{4}$ in toluene with further solvent extraction with $\mathrm{S}\left(\mathrm{CH}_{3}\right)_{2}$ [200]. Using $\mathrm{EtO}_{2}$ as a solvent or by means of ball-milling, the mixed compound $\mathrm{LiLa}\left(\mathrm{BH}_{4}\right)_{3} \mathrm{Cl}$ was produced [200]. $\mathrm{La}\left(\mathrm{BH}_{4}\right)_{3} \cdot n \mathrm{~S}\left(\mathrm{CH}_{3}\right)_{2}$ released $\mathrm{S}\left(\mathrm{CH}_{3}\right)_{2}$ upon heating between 333 and $382 \mathrm{~K}$ and hydrogen at $531 \mathrm{~K}$ [200]. In general, $\mathrm{LiLa}\left(\mathrm{BH}_{4}\right)_{3} \mathrm{X}$, $\mathrm{X}=\mathrm{Cl}, \mathrm{Br}$, and I, can be produced and possess high Li-conductivity [201].

$\mathrm{NaLa}\left(\mathrm{BH}_{4}\right)_{4}$ was obtained by the reaction between pure $\mathrm{La}\left(\mathrm{BH}_{4}\right)_{3}$ and $\mathrm{NaBH}_{4}$, induced by ball-milling [202]. However, the same procedure using $\mathrm{LiBH}_{4}$ does not give $\mathrm{LiLa}\left(\mathrm{BH}_{4}\right)_{4}$ [202]. Any remaining $\mathrm{La}\left(\mathrm{BH}_{4}\right)_{3}$ and $\mathrm{NaBH}_{4}$ continue to react between 355 and $463 \mathrm{~K}$ and $0.1 \mathrm{MPa}$ argon pressure to form more $\mathrm{NaLa}\left(\mathrm{BH}_{4}\right)_{4}$ [202]. $\mathrm{NaLa}\left(\mathrm{BH}_{4}\right)_{4}$ crystallizes in orthorhombic space group Pbcn (Table 10) [202]. $\mathrm{NaLa}\left(\mathrm{BH}_{4}\right)_{4}$ decomposed in several steps, starting at 413-483 K with the release of the remaining solvent (dimethyl sulfide) and some diborane (as read from the TGS-DSC-MS plot in ref. [202]). The subsequent (proper) dehydrogenation reactions can be summarized as [202]:

$$
\begin{gathered}
\mathrm{NaLa}\left(\mathrm{BH}_{4}\right)_{4} \rightarrow \mathrm{La}\left(\mathrm{BH}_{4}\right)_{3}+\mathrm{NaBH}_{4}, 463-483 \mathrm{~K} \\
\mathrm{La}\left(\mathrm{BH}_{4}\right)_{3} \rightarrow \frac{1}{2} \mathrm{LaH}_{2}+\frac{1}{2} \mathrm{LaB}_{6}+11 / 2 \mathrm{H}_{2}, 538-623 \mathrm{~K}
\end{gathered}
$$

Partial reversibility was achieved by the re-formation of $\mathrm{NaBH}_{4}$ at $10 \mathrm{MPa}$ hydrogen pressure, and up to $723 \mathrm{~K}$ [202].

$\mathrm{K}_{3} \mathrm{La}\left(\mathrm{BH}_{4}\right)_{6}$ was produced by the same procedure as $\mathrm{NaLa}\left(\mathrm{BH}_{4}\right)_{4}$, i.e., the addition reaction between $\mathrm{La}\left(\mathrm{BH}_{4}\right)_{3}$ and $3 \mathrm{KBH}_{4}$, assisted by ball-milling [202]. $\mathrm{K}_{3} \mathrm{La}\left(\mathrm{BH}_{4}\right)_{6}$ and $\mathrm{NaLa}\left(\mathrm{BH}_{4}\right)_{4}$ behave in a similar way [202]. $\mathrm{K}_{3} \mathrm{La}\left(\mathrm{BH}_{4}\right)_{6}$ crystallized in a monoclinic $P 2{ }_{1} / n$ (Table 10), double-perovskite structure (Figure 7), and also decomposed at 532-563 K into the precursor borohydrides $\left(\mathrm{La}\left(\mathrm{BH}_{4}\right)_{3}\right.$ and $\left.\mathrm{KBH}_{4}\right)$ [202].

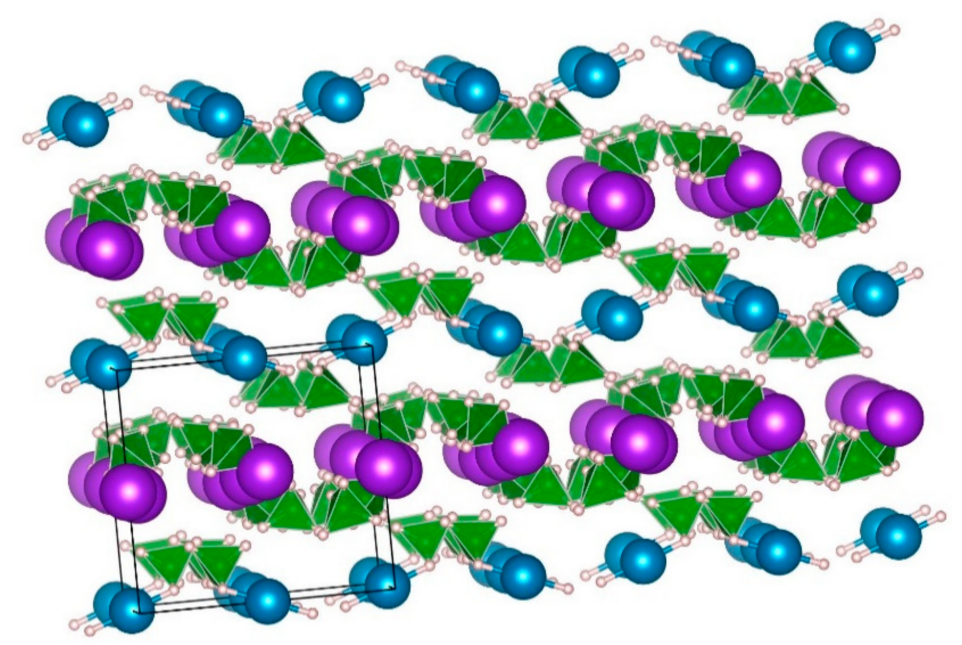

Figure 7. Crystal structure of $\mathrm{K}_{3} \mathrm{La}\left(\mathrm{BH}_{4}\right)_{6}$. Detailed crystal structure can be found in Table 10 .

At these temperatures, the decomposition of $\mathrm{La}\left(\mathrm{BH}_{4}\right)_{3}$ is immediate (Equation (93)) [202]. Between 573 and $673 \mathrm{~K}$, a reaction between $\mathrm{LaH}_{2}$ (the decomposition product of $\mathrm{La}\left(\mathrm{BH}_{4}\right)_{3}$ ) and $\mathrm{KBH}_{4}$ occurred:

$$
\frac{1}{2} \mathrm{LaH}_{2}+3 \mathrm{KBH}_{4} \rightarrow 3 \mathrm{KH}+1 / 2 \mathrm{LaB}_{6}+5 \mathrm{H}_{2}
$$

Partial reversibility was also observed in this case, with the hydrogenation reaction being attributed to the reverse reaction of (94) at $10 \mathrm{MPa} \mathrm{H}_{2}$-pressure and $723 \mathrm{~K}$ [202].

$\mathbf{L i}_{3} \mathrm{~K}_{3} \mathrm{La}_{2}\left(\mathrm{BH}_{4}\right)_{\mathbf{1 2}}$ was observed due to the contamination with small quantities of $\mathrm{LiBH}_{4}$ during the synthesis of $\mathrm{K}_{3} \mathrm{La}\left(\mathrm{BH}_{4}\right)_{6}$ [202]. The crystal structure of $\mathrm{Li}_{3} \mathrm{~K}_{3} \mathrm{La}_{2}\left(\mathrm{BH}_{4}\right)_{12}$ was reported in [202] (Table 10). $\mathrm{Li}_{3} \mathrm{~K}_{3} \mathrm{La}_{2}\left(\mathrm{BH}_{4}\right)_{12}$ is a ionic $\mathrm{Li}^{+}$conductor $\left(6 \times 10^{-7} \mathrm{~S} / \mathrm{cm}\right)$ [203]. 
Table 10. Crystal structures of La-borohydrides.

\begin{tabular}{|c|c|c|c|}
\hline $\begin{array}{l}\text { Material and Hydrogen } \\
\text { Content [wt. \%] }\end{array}$ & Structural Parameters $\left[\AA{ }^{\circ}{ }^{\circ}\right]$ & Atomic Positions & Comments \\
\hline $\begin{array}{c}\mathrm{NaLa}\left(\mathrm{BH}_{4}\right)_{4} \\
7.29\end{array}$ & 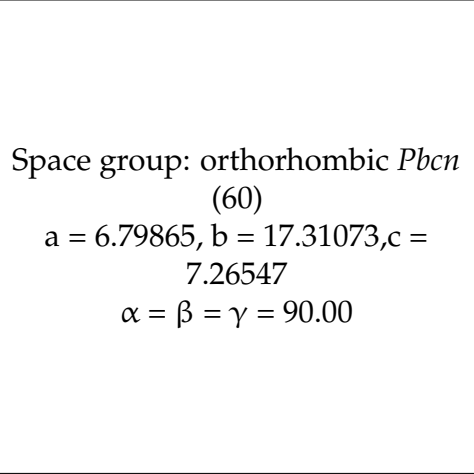 & $\begin{array}{c}\text { Na: } 0.50044,0.07200,0.75028 . \\
\text { La: } 0.00006,0.17197,0.24971 . \\
\text { B: } 0.26676,0.43014,0.88057 . \\
\text { H1: } 0.34758,0.36477,0.88347 . \\
\text { H2. } 0.24611,0.45458,1.03337 . \\
\text { H3: } 0.10366,0.42625,0.80070 . \\
\text { H4: } 0.37496,0.47548,0.79356 . \\
\text { B: } 0.75157,0.19400,0.51886 . \\
\text { H1: } 0.63613,0.20423,0.38704 . \\
\text { H2: } 0.70323,0.13930,0.60198 . \\
\text { H3: } 0.74575,0.25066,0.62265 . \\
\text { H4: } 0.92434,0.18235,0.45697\end{array}$ & $\begin{array}{l}\text { [202]. } \\
\mathrm{NaLa}\left(\mathrm{BH}_{4}\right)_{4} \text { is isostructural to } \\
\mathrm{NaCe}\left(\mathrm{BH}_{4}\right)_{4} \text { and } \mathrm{NaPr}\left(\mathrm{BH}_{4}\right)_{4} \\
\text { [204] }\end{array}$ \\
\hline $\begin{array}{c}\mathrm{K}_{3} \mathrm{La}\left(\mathrm{BH}_{4}\right)_{6} \\
7.01\end{array}$ & $\begin{array}{l}\text { Space group: monoclinic } P 2_{1} / n \\
\qquad \begin{array}{c}(14) \\
a=7.93840, b=8.35246 \\
\quad c=11.57068 \\
\alpha=\gamma=90, \beta=90.18977\end{array}\end{array}$ & $\begin{array}{c}\text { K1: } 0.5,0.5,0.5 . \text { K2: } 0.47777, \\
\text { 0.05175, 0.25048. La: } 0,0,0.5 . \\
\text { B1: } 0.34697,0.83332,0.0777 . \\
\text { H1: } 0.40173,0.79562,0.16487 . \\
\text { H2: } 0.28607,0.95646,0.08622 . \\
\text { H3: } 0.45213,0.83873,0.01072 . \\
\text { H4: } 0.24803,0.74232,0.04903 . \\
\text { B2: } 0.16081,0.32239,0.07051 . \\
\text { H1: } 0.09016,0.29934,0.15464 . \\
\text { H2: } 0.23328,0.43994,0.07762 . \\
\text { H3: } 0.25285,0.21998,0.05400 . \\
\text { H4: } 0.06681,0.33015, \\
\text {-0.00418. B3: } 0.63098, \\
\text { 0.43325, 0.22717. H1: } 0.72435, \\
\text { 0.37192, } 0.28787 . \text { H2: } 0.55241, \\
\text { 0.52310, } 0.27813 . \text { H3: } 0.70283, \\
\text { 0.49845, } 0.15596 . \text { H4: } 0.54446, \\
0.33942,0.18673\end{array}$ & [202] \\
\hline $\begin{array}{c}\mathrm{Li}_{3} \mathrm{~K}_{3} \mathrm{La}_{2}\left(\mathrm{BH}_{4}\right)_{12} \\
8.14\end{array}$ & $\begin{array}{l}\text { Space group: cubic } I a-3 d(230) \\
\qquad \begin{array}{c}a=17.60563, b=17.60563 \\
\qquad=17.60563 \\
\alpha=\beta=\gamma=90\end{array}\end{array}$ & $\begin{array}{c}\text { K: } 0.25,0.8750,0.5 . \text { Li: } 0.3750, \\
\text { 0, } 0.25 . \text { La: } 0.5,0,0 . \\
\text { B: } 0.4,0.7,0.28 . \text { H1: } 0.36161, \\
\text { 0.75067, } 0.28790 . \text { H2: } 0.45847, \\
0.71997,0.26308 . \text { H3: } 0.40365, \\
\text { 0.66722, } 0.33496 . \text { H4: } 0.37619, \\
\text { 0.66215, } 0.23408\end{array}$ & [202] \\
\hline
\end{tabular}

$\mathrm{Ce}\left(\mathrm{BH}_{4}\right)_{3}$ was also produced by mechanical milling of anhydrous $\mathrm{CeCl}_{3}$ and $\mathrm{LiBH}_{4}$ for different milling times (1 to $48 \mathrm{~h}$ ) [199]. The behavior of $\mathrm{Ce}\left(\mathrm{BH}_{4}\right)_{3}$ is very similar to $\mathrm{La}\left(\mathrm{BH}_{4}\right)_{3}$ [199]: $\mathrm{CeF}_{3}$ was not as reactive as $\mathrm{LaCl}_{3}$, and dehydrogenation of these mixtures indicates a multistep process; the main dehydrogenation event occurred at approximately $498 \mathrm{~K}$ for the $\mathrm{CeCl}_{3}$ precursor and $563 \mathrm{~K}_{\text {for }} \mathrm{CeF}_{3}$. The difference was also explained by the formation of $\mathrm{Ce}\left(\mathrm{BH}_{4}\right)_{3}$ in the first case, and the in-situ reaction between $\mathrm{LiBH}_{4}$ and $\mathrm{CeF}_{3}$ in the second case [199]. In both cases, the dehydrogenation products were $\mathrm{CeH}_{2}$, $\mathrm{CeB}_{6}, \mathrm{H}_{2}$, and $\mathrm{LiCl}$ or $\mathrm{LiF}$. Standard dehydrogenation enthalpies were estimated as 23.2 and $25.6 \mathrm{~kJ} / \mathrm{mol} \mathrm{H}_{2}$, respectively [199]. A partial hydrogen uptake of the dehydrogenated materials was observed ( $623 \mathrm{~K}$ or $723 \mathrm{~K}, 10 \mathrm{MPa}, 24 \mathrm{~h}$ ) [199]. Gennari et al. reported the production of $\mathrm{Ce}\left(\mathrm{BH}_{4}\right)_{3}$ by the mechanical ball-milling of $\mathrm{CeCl}_{3}+3 \mathrm{LiBH}_{4}$ [205]. $\mathrm{Ce}\left(\mathrm{BH}_{4}\right)_{3}$ (plus $\mathrm{LiCl}$ ) desorbed hydrogen in three endothermic events at approximately 503, 533, and $533 \mathrm{~K}$ (as read from DSC curves in [205]). The proposed global dehydrogenation products are $\mathrm{CeH}_{2}, \mathrm{~B}$ or $\mathrm{CeB}_{6}$, and $\mathrm{H}_{2}$, with $\mathrm{Ce}_{2}\left(\mathrm{~B}_{12} \mathrm{H}_{12}\right)_{3}$ as an intermediary [205]. $\mathrm{Ce}\left(\mathrm{BH}_{4}\right)_{3}$ was also produced in the same way as $\mathrm{La}\left(\mathrm{BH}_{4}\right)_{3}$, i.e., in toluene with further solvent extraction with $\mathrm{S}\left(\mathrm{CH}_{3}\right)_{2}$ [200]. $\mathrm{Ce}\left(\mathrm{BH}_{4}\right)_{3}$, as $\mathrm{La}\left(\mathrm{BH}_{4}\right)_{3}$, crystalizes in rhombohedral (r-) (Figure 3) and cubic 
(c-) polymorphs, Table 11 [200]. $\mathrm{Ce}\left(\mathrm{BH}_{4}\right)_{3}$ released $\sim 6 \mathrm{wt} \%$ between $473 \mathrm{~K}$ and $573 \mathrm{~K}$, with an endothermic peak at $524 \mathrm{~K}$, and simultaneous $\mathrm{H}_{2}$ and $\mathrm{B}_{2} \mathrm{H}_{6}$ release [200]. $\mathbf{L i C e}(\mathbf{B H})_{3} \mathbf{C l}$ was produced as a by-product, and it is reported to have Li-ion conductivity [200].

Table 11. Crystal structures of Ce-borohydrides.

\begin{tabular}{|c|c|c|c|}
\hline $\begin{array}{l}\text { Material and Hydrogen } \\
\text { Content [wt.\%] }\end{array}$ & Structural Parameters $\left[\AA{ }^{\circ},{ }^{\circ}\right]$ & Atomic Positions & Comments \\
\hline $\begin{array}{l}\mathrm{r}-\mathrm{Ce}\left(\mathrm{BH}_{4}\right)_{3} \\
\quad 6.55\end{array}$ & $\begin{array}{c}\text { Space group: trigonal } R-3 c \\
(167) \\
a=b=7.3745(1), c=20.1567(2) \\
\alpha=\beta=90, \gamma=120\end{array}$ & $\begin{array}{c}\text { Ce: } 0,0,0 . \text { B: } 0.632(2), 0, \frac{1}{4} . \text { H1: } \\
0.461(2),-0.094(5), 0.261(2) . \text { H2: } \\
0.759(2), 0.026(5), 0.288(2)\end{array}$ & $\begin{array}{l}{[200] .} \\
\text { Isostructural to } \mathrm{r}-\mathrm{La}\left(\mathrm{BH}_{4}\right)_{3}\end{array}$ \\
\hline $\begin{array}{l}\mathrm{c}-\mathrm{Ce}\left(\mathrm{BH}_{4}\right)_{3} \\
\quad 6.55\end{array}$ & $\begin{array}{l}\text { Space group: cubic } F m-3 c(226) \\
\qquad \begin{array}{c}a=b=c=11.7106(6) \\
\alpha=\beta=\gamma=90\end{array}\end{array}$ & $\begin{array}{c}\text { Ce: } 0,0,0 . \text { B: } 0,0, \frac{1}{4} . \mathbf{H}: 0 \text {, } \\
0.4075(1), 0.3104(1)\end{array}$ & $\begin{array}{l}{[200] \text {. }} \\
\text { Isostructural to c- } \mathrm{La}\left(\mathrm{BH}_{4}\right)_{3}\end{array}$ \\
\hline $\begin{array}{l}\mathrm{NaCe}\left(\mathrm{BH}_{4}\right)_{4} \\
7.25\end{array}$ & $\begin{array}{l}\text { Space group: orthorhombic } \\
\text { Pbcn (60) } \\
\begin{array}{c}\mathrm{a}=6.8028(5), \mathrm{b}=17.5181(13), \mathrm{c} \\
=7.2841(5) \\
\alpha=\beta=\gamma=90\end{array}\end{array}$ & $\begin{array}{c}\text { Na1: 0.50044, 0.0720, 0.75028. Ce2: } \\
\text { 0.00006, 0.17197, 0.24971. B3: } \\
\text { 0.26676, 0.43014, 0.88057. H14: } \\
\text { 0.34758, 0.36477, 0.88347. H15: } \\
\text { 0.24611, 0.45458, 0.03337. H16: } \\
\text { 0.10366, 0.42625, 0.80070. H17: } \\
\text { 0.37496, 0.47548, 0.79356. B8: } \\
\text { 0.75157, 0.1940, 0.51886. H19: } \\
\text { 0.63613, 0.20423, 0.38704. H110: } \\
\text { 0.70323, 0.13930, 0.60198. H111: } \\
\text { 0.74575, 0.25066, 0.62265. H112: } \\
\text { 0.92434, 0.18235, 0.45697 }\end{array}$ & [204] \\
\hline $\begin{array}{c}\mathrm{Li}_{3} \mathrm{~K}_{3} \mathrm{Ce}_{2}\left(\mathrm{BH}_{4}\right)_{12} \\
8.11\end{array}$ & $\begin{array}{l}\text { Space group: cubic } I a-3 d(230) \\
\begin{array}{c}\mathrm{a}=17.60756(4), \mathrm{b}= \\
17.60756(4), c=17.60756(4) \\
\alpha=\beta=\gamma=90\end{array}\end{array}$ & 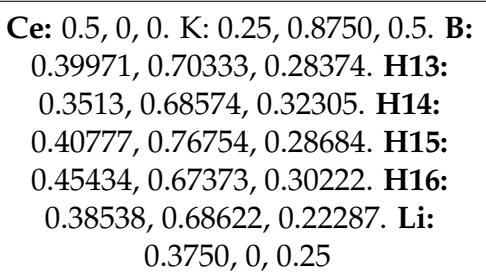 & [203] \\
\hline
\end{tabular}

$\mathrm{NaCe}\left(\mathrm{BH}_{4}\right)_{4}$ was produced by mechanical milling of $\mathrm{Ce}\left(\mathrm{BH}_{4}\right)_{3}$ and $\mathrm{NaBH}_{4}$, and the milling was performed with careful control of the milling time and pauses [204]. $\mathrm{Ce}\left(\mathrm{BH}_{4}\right)_{3}$ was produced first as described above, and then used to produce $\mathrm{NaCe}\left(\mathrm{BH}_{4}\right)$. The $\mathrm{NaCe}\left(\mathrm{BH}_{4}\right)_{4}$ is isostructural to $\mathrm{NaLa}\left(\mathrm{BH}_{4}\right)_{4}$ [204] (Table 11). Heating of the ballmilled mixture of $\mathrm{Ce}\left(\mathrm{BH}_{4}\right)_{3}$ and $\mathrm{NaBH}_{4}$ induced the supplementary addition reaction between the (initially unreacted) $\mathrm{Ce}\left(\mathrm{BH}_{4}\right)_{3}$ and $\mathrm{NaBH}_{4}$ at approximately $373 \mathrm{~K}$ [204]. The maximum amount of $\mathrm{NaCe}\left(\mathrm{BH}_{4}\right)_{4}$ occurred at 446-460 K [204]. However, the presence of two unknown compounds that might be solvates of Ce-borohydride was reported [204]. The release of solvents $\left.\left(\mathrm{S}_{(} \mathrm{CH}_{3}\right)_{2}\right), \mathrm{B}_{2} \mathrm{H}_{6}$, and $\mathrm{H}_{2}$ occurred over a narrow temperature range, 453-498 $\mathrm{K}$, with a second release of $\mathrm{B}_{2} \mathrm{H}_{6}$ and $\mathrm{H}_{2}$ at $523 \mathrm{~K}$ (as read from TGA-DSCMS plots) [204]. The decomposition of $\mathrm{NaCe}\left(\mathrm{BH}_{4}\right)_{4}$ is understood to first form Ce- and Na-borohydrides [204].

$\mathrm{K}_{3} \mathrm{Ce}\left(\mathbf{B H}_{4}\right)_{6}\left(P 2_{1} / n\right.$ [22]) was briefly mentioned as a by-product of the synthesis of $\mathrm{Li}_{3} \mathrm{~K}_{3} \mathrm{Ce}_{2}\left(\mathrm{BH}_{4}\right)_{12}$ [203]. $\mathbf{L i}_{3} \mathbf{K}_{3} \mathbf{C e}_{\mathbf{2}}\left(\mathbf{B H}_{4}\right)_{\mathbf{1 2}}$ is an ionic $\mathrm{Li}^{+}$conductor; its bulk conductivity was reported to be nearly seven orders of magnitude higher $\left(3 \times 10^{-7} \mathrm{~S} / \mathrm{cm}\right)$ than in $\mathrm{Li}_{3} \mathrm{~Tb}_{3} \mathrm{Te}_{2} \mathrm{O}_{12}$ (Table 11) [203]. Its conductivity is explained by a "paddle-wheel" (combined size and ionic dynamical disorder) effect of the $\left[\mathrm{BH}_{4}\right]^{-1}$ on $\mathrm{Li}^{+}$[203]. Li substitution by $\mathrm{Na}$, $\mathrm{K}$, or $\mathrm{Rb}$, Ce substitution by $\mathrm{Ca}, \mathrm{Sr}$ or $\mathrm{Eu}$, or $\left[\mathrm{BH}_{4}\right]^{-1}$ substitution by $\mathrm{Cl}^{-}$could modify the conductivity properties [203]. As stated in the introductory section, borohydrides might be an option in batteries, providing high ionic conductivity at room temperature. Thus, ionic conductivity is studied and data are reported recently [206]. However, we must perform a brief parenthesis to link ion conductivity (ion mobility) to dehydrogenation properties. 
Wu proposed that tuning the mobility of small ions can help to improve the hydrogen storage properties of metal hydride materials, as do particle size reduction, catalyst, or destabilization [207]. Luo et al. proposed that ionic conductivity is influenced by ionic radius and structure [206]. Wu describes that materials with a perovskite structure might accelerate hydrogen mobility [207], while Davies et al. [208] and Anderson et al. [209] suggest that halide substitution in amide materials improves ionic conductivity and hydrogen release properties. Unfortunately, not enough data on borohydrides are available to perform a correlation.

$\mathbf{R} \mathbf{b}_{3} \mathbf{C e}\left(\mathbf{B H}_{4}\right)_{6}$ (monoclinic $P 2_{1} / n$ ) was briefly mentioned in a recent report [69].

The formation of reactive hydride composites of Ce-Li was studied by Gennari et al. [210]. They produced, using mechanical milling, the following mixture [210]:

$$
6 \mathrm{LiBH}_{4}+\mathrm{CeCl}_{3} \rightarrow \mathrm{Ce}\left(\mathrm{BH}_{4}\right)_{3}+3 \mathrm{LiCl}+3 \mathrm{LiBH}_{4}
$$

The mixture decomposed in a multistep pathway starting at $493 \mathrm{~K}$ and going up to $673 \mathrm{~K}$ [210]. The mixture presented partial reversibility at $673 \mathrm{~K}$ and $6 \mathrm{MPa}$. After the second dehydrogenation, the products included $\mathrm{CeB}_{6}, \mathrm{CeH}_{2}, \mathrm{CeB}_{4}, \mathrm{LiH}$, and $\mathrm{H}_{2}$, with the first two being confirmed by X-ray diffraction [210].

$\operatorname{Pr}\left(\mathbf{B H}_{4}\right)_{3}$ was reported recently; this material was produced by the reaction of premilled $\mathrm{PrH}_{3}$ with $\mathrm{S}\left(\mathrm{CH}_{3}\right) \mathrm{BH}_{3}$ in toluene, with further extraction/purification with DMS and drying [31]. $\mathrm{LiPr}\left(\mathrm{BH}_{4}\right)_{3} \mathrm{Cl}$ can also be produced during the synthesis of $\operatorname{Pr}\left(\mathrm{BH}_{4}\right)_{3}$ when using $\mathrm{LiBH}_{4}$ and $\mathrm{PrCl}_{3}$ as precursors [211]. $\operatorname{Pr}\left(\mathrm{BH}_{4}\right)_{3}$ presents different phases when heated under hydrogen pressure (4 MPa): $\alpha-, \beta-, \beta^{\prime}-, \beta^{\prime \prime}-$, and $\mathrm{r}-\operatorname{Pr}\left(\mathrm{BH}_{4}\right)_{3}$ (Table 12). $\alpha$ - $\operatorname{Pr}\left(\mathrm{BH}_{4}\right)_{3}$ is stable at room temperature and isostructural to $\alpha-\mathrm{Y}\left(\mathrm{BH}_{4}\right)_{3}$ and $\alpha-\mathrm{Gd}\left(\mathrm{BH}_{4}\right)_{3} \cdot \beta-\operatorname{Pr}\left(\mathrm{BH}_{4}\right)_{3}$ appeared along with $\alpha-\operatorname{Pr}\left(\mathrm{BH}_{4}\right)_{3}$ during the drying of $\operatorname{Pr}\left(\mathrm{BH}_{4}\right)_{3} \cdot S\left(\mathrm{CH}_{3}\right)_{2}$, i.e., from the solvated material. $\beta-\operatorname{Pr}\left(\mathrm{BH}_{4}\right)_{3}$ is a high-pressure polymorph $\left(4 \mathrm{MPa} \mathrm{H}_{2}\right.$ pressure and $463 \mathrm{~K})$ [31]. At $\sim 49 \mathrm{~K}, \beta-\operatorname{Pr}\left(\mathrm{BH}_{4}\right)_{3}$ transformed to $\beta^{\prime}-\operatorname{Pr}\left(\mathrm{BH}_{4}\right)_{3}$, with contraction of the unit cell. At $463 \mathrm{~K}$, a further contraction of the $\beta^{\prime}$-phase occurred, producing $\beta^{\prime \prime}-\operatorname{Pr}\left(\mathrm{BH}_{4}\right)_{3}$ [31]. Further heating produces the disappearance of $\alpha-\operatorname{Pr}\left(\mathrm{BH}_{4}\right)_{3}$ and the emergence of r-Pr$\left(\mathrm{BH}_{4}\right)_{3}$. The decomposition of $\operatorname{Pr}\left(\mathrm{BH}_{4}\right)_{3}$ was registered at $520 \mathrm{~K}$, with practically no $\mathrm{B}_{2} \mathrm{H}_{6}$ evolution; the reaction is [31]:

$$
2 \operatorname{Pr}\left(\mathrm{BH}_{4}\right)_{3} \rightarrow \operatorname{PrB}_{6}+\operatorname{PrH}_{2}+11 \mathrm{H}_{2}
$$

$\mathrm{NaPr}\left(\mathrm{BH}_{4}\right)_{4}$ was produced by the addition reaction between $\mathrm{NaBH}_{4}$ and halide-free $\operatorname{Pr}\left(\mathrm{BH}_{4}\right)_{3}$. The addition reaction was carried out by ball-milling, with careful control of the milling time/pause [204]. $\mathrm{NaPr}\left(\mathrm{BH}_{4}\right)_{4}$ crystallizes in an orthorhombic unit cell (Pbcn), and is isostructural to $\mathrm{NaLa}\left(\mathrm{BH}_{4}\right)_{4}$ (Table 12) [204]. In-situ diffraction studies during heating of the $\mathrm{NaBH}_{4}$ and $\operatorname{Pr}\left(\mathrm{BH}_{4}\right)_{3}$ mixture, i.e., $\mathrm{NaPr}\left(\mathrm{BH}_{4}\right)_{4}$, demonstrated the formation of two unidentified crystalline materials and the decrease in intensity of $\mathrm{NaPr}\left(\mathrm{BH}_{4}\right)_{4} \mathrm{XRD}$ reflections at about $463 \mathrm{~K}$ (as read from an in-situ synchrotron radiation x-ray diffraction pattern) [204]. Further heating led to the decomposition of the unidentified materials. Partial reversibility (low hydrogenation levels over several cycles) was achieved in this material [204]. 
Table 12. Crystal structures of Pr-borohydrides.

\begin{tabular}{|c|c|c|c|}
\hline $\begin{array}{l}\text { Material and Hydrogen } \\
\text { Content [wt. \%] }\end{array}$ & Structural Parameters $\left[\AA^{\circ},{ }^{\circ}\right]$ & Atomic Positions & References and Comments \\
\hline $\begin{array}{c}\alpha-\operatorname{Pr}\left(\mathrm{BH}_{4}\right)_{3} \\
\quad 6.52\end{array}$ & $\begin{array}{l}\text { Space group: cubic } P a-3(205) \\
\qquad \begin{array}{c}a=b=c=11.2941(5) \\
\alpha=\beta=\gamma=90\end{array}\end{array}$ & $\begin{array}{c}\text { Pr: 0.2179, 0.2179, 0.2179. B: } \\
\text { 0.1930, 0.2473, 0.9682. H13: } \\
\text { 0.2909, 0.2534, 0.0243. H14: } \\
\text { 0.1043, 0.2257, 0.0351. H15: } \\
\text { 0.1752, 0.3475, 0.9192. H16: } \\
\text { 0.2014, 0.1623, 0.8942 }\end{array}$ & [31] \\
\hline $\begin{array}{c}\beta-\operatorname{Pr}\left(\mathrm{BH}_{4}\right)_{3} \\
\beta^{\prime}-\operatorname{Pr}\left(\mathrm{BH}_{4}\right)_{3} \\
\beta^{\prime \prime}-\operatorname{Pr}\left(\mathrm{BH}_{4}\right)_{3} \\
6.52\end{array}$ & $\begin{array}{l}\text { Space group: cubic Fm-3c (226) } \\
\qquad \begin{array}{c}\mathrm{a}=\mathrm{b}=\mathrm{c}=11.458(2) \\
\mathrm{a}=\mathrm{b}=\mathrm{c}=11.3283(6) \\
\mathrm{a}=\mathrm{b}=\mathrm{c}=11.1438(2) \\
\alpha=\beta=\gamma=90\end{array}\end{array}$ & $\begin{array}{c}\text { Pr: } 0,0,0 . \text { B: } 0,0,0.25 . \text { H13: } 0 \\
0.4069,0.3116\end{array}$ & {$[31]$} \\
\hline $\begin{array}{l}\mathrm{r}-\operatorname{Pr}\left(\mathrm{BH}_{4}\right)_{3} \\
\quad 6.52\end{array}$ & $\begin{array}{l}\text { Space group: trigonal } R-3 c \\
\text { (167) } \\
\begin{array}{c}a=b=7.373(6), c=19.89(2) \\
\alpha=\beta=90, \gamma=120\end{array}\end{array}$ & $\begin{array}{c}\text { Pr: } 0,0,0 . \text { B: } 0.6202(2), 0,0.25 \\
\text { D13: } 0.4835(4),-0.1056(10) \\
\text { 0.2881(1). D14: } 0.7699(3) \\
\text { 0.1072(8), } 0.2834(1)\end{array}$ & {$[31]$} \\
\hline $\begin{array}{l}\mathrm{NaPr}\left(\mathrm{BH}_{4}\right)_{4} \\
7.22\end{array}$ & $\begin{array}{l}\text { Space group: orthorhombic } \\
\text { Pbcn (60) } \\
\begin{array}{c}\mathrm{a}=6.7617(2), \mathrm{b}=17.4679(7) \\
\mathrm{c}=7.2523(3) \\
\alpha=\beta=\gamma=90.00\end{array}\end{array}$ & $\begin{array}{c}\text { Na: } 0.50044,0.0720,0.75028 . \\
\text { Pr: } 0.00006,0.17197,0.24971 . \\
\text { B: } 0.26676,0.43014,0.88057 \\
\text { H14: } 0.34758,0.36477,0.88347 \\
\text { H15: } 0.24611,0.45458,0.03337 . \\
\text { H16: } 0.10366,0.42625,0.8007 \\
\text { H17: } 0.37496,0.47548,0.79356 . \\
\text { B8: } 0.75157,0.1940,0.51886 . \\
\text { H19: } 0.63613,0.20423,0.38704 . \\
\text { H110: 0.70323, 0.13930, } \\
\text { 0.60198. H111: 0.74575, } \\
\text { 0.25066, 0.62265. H112: } \\
\text { 0.92434, 0.18235, 0.45697 }\end{array}$ & [204] \\
\hline
\end{tabular}

$\mathrm{Nd}\left(\mathrm{BH}_{4}\right)_{3}$ was produced by the reaction of pre-milled $\mathrm{NdH}_{3}$ with $\mathrm{S}\left(\mathrm{CH}_{3}\right) \mathrm{BH}_{3}$ in toluene, with further extraction/purification with DMS and drying at $453 \mathrm{~K}$ under vacuum [31]. $\alpha-\mathrm{Nd}\left(\mathrm{BH}_{4}\right)_{3}$ is isostructural to the room temperature polymorphs of $\alpha-\mathrm{Y}\left(\mathrm{BH}_{4}\right)_{3}$ and $\alpha-G d\left(B_{4}\right)_{3}$ [31], with cubic group symmetry $P a-3$, and $\mathrm{a}=11.2462(2) \AA$ [17]. $\beta$ $\mathrm{Nd}\left(\mathrm{BH}_{4}\right)_{3}$ is also a high-pressure polymorph $(543 \mathrm{~K}, 9.8 \mathrm{MPa})$ and is isostructural to $\beta-\mathrm{RE}\left(\mathrm{BH}_{4}\right)_{3}, \mathrm{RE}=\mathrm{Ce}, \mathrm{Sm}, \mathrm{Ho}, \mathrm{Y}, \mathrm{Er}, \mathrm{Tm}, \mathrm{Yb}$ (Figure 8) [31]. $\mathrm{Nd}\left(\mathrm{BH}_{4}\right)_{3}$ also undergoes phase transitions when heated under pressure $\beta$ - to $\beta^{\prime}$ - at $447-463 \mathrm{~K}$, and then to $-\beta^{\prime \prime}-$ $463-543 \mathrm{~K}$ [31]. Non-solvated $\mathrm{Nd}\left(\mathrm{BH}_{4}\right)_{3}$ decomposed at approximately $523 \mathrm{~K}$, in a reaction similar to (97) $[17,31]$.

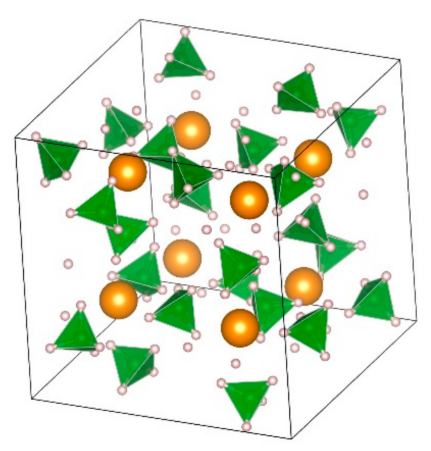

(a)

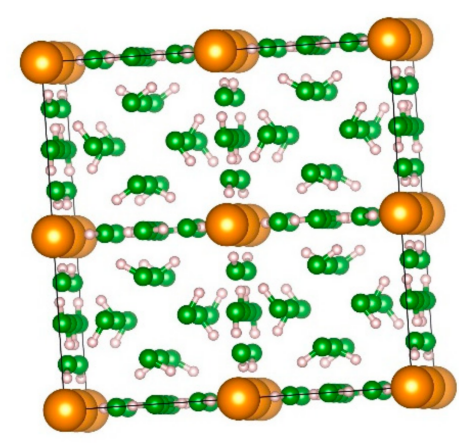

(b)

Figure 8. Crystal structure of (a) $\alpha-\mathrm{Nd}\left(\mathrm{BH}_{4}\right)_{3}$ (isostructural to $\alpha-\mathrm{Y}\left(\mathrm{BH}_{4}\right)_{3}$ and $\alpha-\mathrm{Gd}\left(\mathrm{BH}_{4}\right)_{3}$ [31]); and (b) $\beta-\mathrm{Nd}\left(\mathrm{BH}_{4}\right)_{3}$ (isostructural to $\beta-\mathrm{RE}\left(\mathrm{BH}_{4}\right)_{3}, \mathrm{RE}=\mathrm{Ce}, \mathrm{Sm}, \mathrm{Ho}, \mathrm{Y}, \mathrm{Er}, \mathrm{Tm}, \mathrm{Yb}$ ). 
No Pm-borohydrides were located during the investigation for this review.

A few reports about $\mathrm{Sm}\left(\mathbf{B H}_{4}\right)_{2}$ were located during the preparation of this review; in one report, $\mathrm{SmCl}_{3}$ reacted with $\mathrm{LiBH}_{4}(1: 3)$ in anhydrous diethyl ether. During the reaction, $\mathrm{Sm}^{+3}$ was reduced to $\mathrm{Sm}^{+2}$ to form $\mathrm{Sm}\left(\mathrm{BH}_{4}\right)_{2}$. Adding $\mathrm{S}\left(\mathrm{CH}_{3}\right)_{2}$, and further drying/annealing allowed the production of non-solvated $\operatorname{Sm}\left(\mathrm{BH}_{4}\right)_{2}$ material above 438 $\mathrm{K}$ [212]. In another report, $\mathrm{Sm}\left(\mathrm{BH}_{4}\right)_{2}$ was produced by the reaction between $\mathrm{SmH}_{2}$ and THF. $\mathrm{BH}_{3}(1 \mathrm{M})$ in THF for $48 \mathrm{~h}$ at $338 \mathrm{~K}$ [213]. In another type of synthesis, ballmilling/mixing of $\mathrm{LiBH}_{4}$ and $\mathrm{SmCl}_{3}$ (6:1) produced two Sm-borohydrides: $\alpha$-Sm( $\left.\mathbf{B} \mathbf{B H}_{4}\right)_{3}$ and $\beta-\mathrm{Sm}\left(\mathrm{BH}_{4}\right)_{3}$ [214].

$\mathrm{Sm}\left(\mathrm{BH}_{4}\right)_{2}$ crystallized in the orthorhombic Pbcn space group (Table 13) $[17,212]$. $\mathrm{Sm}\left(\mathrm{BH}_{4}\right)_{2}$ is isostructural to $\mathrm{Sr}\left(\mathrm{BH}_{4}\right)_{2}$ and $\mathrm{Eu}\left(\mathrm{BH}_{4}\right)_{2}$ [213]. It is worth mentioning that $\mathrm{Eu}$ and Sm can appear as divalent and trivalent cations, and some of their corresponding borohydrides have been reported. The structure of $\mathrm{Sm}\left(\mathrm{BH}_{4}\right)_{2}$ was described as $\left[\mathrm{Sm}\left(\mathrm{BH}_{4}\right)_{6}\right]$ sharing-edges octahedra (with other two octahedra), building chains in the c-direction [214]. Each chain of octahedra is connected via corner-sharing to four others; each $\left[\mathrm{BH}_{4}\right]^{-1}$ tetrahedra is surrounded by $3 \mathrm{Sm}$ atoms in a distorted trigonal planar environment [214].

Table 13. Crystal structures of Sm-borohydrides.

\begin{tabular}{|c|c|c|c|}
\hline $\begin{array}{c}\text { Material and Hydrogen } \\
\text { Content [wt. \%] }\end{array}$ & Structural Parameters $\left[\AA{ }^{\circ},{ }^{\circ}\right]$ & Atomic Positions & Comments \\
\hline $\begin{array}{c}\mathrm{Sm}\left(\mathrm{BH}_{4}\right)_{2} \\
4.48\end{array}$ & $\begin{array}{c}\text { Space group: orthorhombic } \\
\text { Pbcn }(60) \\
\begin{array}{c}\mathrm{a}=6.97129(14), \mathrm{b}=8.43870(17) \\
\mathrm{c}=7.56841(14) \\
\alpha=\beta=\gamma=90\end{array}\end{array}$ & $\begin{array}{c}\text { Sm: } 0,0.15216(14), 0.25 . \text { B: } 0.2544(14) \\
0.3710(18), 0.4218(14) . \text { H1: } 0.384(4) \\
0.292(4), 0.369(6) . \text { H2: } 0.153(6) \\
0.292(5), 0.514(7) . \text { H3: } 0.164(7) \\
0.421(6), 0.300(4) . \text { H4: } 0.316(6) \\
0.479(5) 0.506(7)\end{array}$ & [212] \\
\hline
\end{tabular}

The decomposition of pure $\mathrm{Sm}\left(\mathrm{BH}_{4}\right)_{2}$ occurred at $\sim 608 \mathrm{~K}$, with no evidence of the formation of crystalline $\mathrm{SmB}_{6}$ [212]. In the 6:1 ball-milled mixture of $\mathrm{LiBH}_{4}$ and $\mathrm{SmCl}_{3}$ at $473 \mathrm{~K}$, the reduction of trivalent borohydride to divalent borohydride with diborane release was proposed [214]. TG measurements of the 6:1 ball-milled mixture of $\mathrm{LiBH}_{4}$ and $\mathrm{SmCl}_{3}$ presented two mass loss events at approximately $448 \mathrm{~K}$ and $598 \mathrm{~K}$ [214]. Crystalline $\mathrm{Sm}\left(\mathrm{BH}_{4}\right)_{2}$ from the reduced ball-milled mixture decomposed at lower temperatures than the solvent-extracted material. This difference in decomposition temperatures was explained by the presence of $\mathrm{LiCl}$ and other $\mathrm{Sm}$-compounds that modify/destabilize the Sm-borohydrides [212]. Additionally, in the 6:1 ball-milled mixture of $\mathrm{LiBH}_{4}$ and $\mathrm{SmCl}_{3}$, the formation of $\mathrm{LiSm}\left(\mathrm{BH}_{4}\right)_{3} \mathrm{Cl}$ as a secondary reaction between $\mathrm{LiCl}$ and $\mathrm{Sm}\left(\mathrm{BH}_{4}\right)_{2}$ was proposed upon heating at $453 \mathrm{~K}$ [214].

MSm $\left(\mathrm{BH}_{4}\right)_{3}$ were produced by the ball-milling of $\mathrm{Sm}\left(\mathrm{BH}_{4}\right)_{2}$ and $\mathrm{M}\left(\mathrm{BH}_{4}\right)_{3}$ where, for $\mathrm{M}=\mathrm{K}$, the bimetallic borohydride was observed right after ball milling and, for $\mathrm{M}=\mathrm{Rb}$ and $\mathrm{Cs}$, further heating of the milled mixture led to the formation of the bimetallic borohydrides [213]. The $\mathrm{MSm}\left(\mathrm{BH}_{4}\right)_{3}$ compounds $\mathrm{M}=\mathrm{K}, \mathrm{Rb}$, and $\mathrm{Cs}$ are isostructural to $\operatorname{MSr}\left(\mathrm{BH}_{4}\right)_{3}$; i.e., they have perovskite-type structures [213]. The similarities are attributed to similar cation size [213]. CsSm $\left(\mathbf{B H}_{4}\right)_{3}$ presented two second-order polymorphic transitions, the first one at $354 \mathrm{~K}$, possibly related to the formation of $\alpha^{\prime}-\mathrm{CsSm}\left(\mathrm{BH}_{4}\right)_{3}$, and the second at $\sim 618 \mathrm{~K}$, involving the formation of $\beta-\mathrm{CsSm}\left(\mathrm{BH}_{4}\right)_{3}$, which only exists between 635 and $655 \mathrm{~K}$ [213]. All of the $\mathrm{MSm}\left(\mathrm{BH}_{4}\right)_{3}$ phases, $\mathrm{M}=\mathrm{K}, \mathrm{Rb}$, and $\mathrm{Cs}$, decomposed at $\mathrm{T}>553 \mathrm{~K}$, and the proposed reaction is [213]:

$$
3 \mathrm{MSm}\left(\mathrm{BH}_{4}\right)_{3} \rightarrow 3 \mathrm{MBH}_{4}+2 \mathrm{SmH}_{2}+\mathrm{SmB}_{6}+10 \mathrm{H}_{2}
$$

Very importantly, partial rehydrogenation has been achieved for the $\mathrm{MSm}\left(\mathrm{BH}_{4}\right)_{3}$ materials by heating at $623 \mathrm{~K}$ and $19 \mathrm{MPa}$ hydrogen pressure; the authors mentioned that it is probable that the original double-cation borohydrides were re-formed [213]. 
Recently, the study of Eu-borohydrides has gained attention due to the luminescence of these compounds. $\mathbf{E u}\left(\mathbf{B H}_{4}\right)_{2}$ can be produced by the reaction of freshly ball-milled $\mathrm{EuH}_{2}$ with triethylamine borane [215]:

$$
\mathrm{EuH}_{2}+2\left(\mathrm{C}_{2} \mathrm{H}_{5}\right)_{3} \mathrm{~N}-\mathrm{BH}_{3} \rightarrow \mathrm{Eu}\left(\mathrm{BH}_{4}\right)_{2}+2 \mathrm{~N}\left(\mathrm{C}_{2} \mathrm{H}_{5}\right)_{3}
$$

The initial mixture was kept at $373 \mathrm{~K}$ overnight under reflux, and then at $418 \mathrm{~K}$ for $5 \mathrm{~h}$ [215]. After that, $\mathrm{Eu}\left(\mathrm{BH}_{4}\right)_{2}$ was extracted and dried. $\mathrm{Eu}\left(\mathrm{BH}_{4}\right)_{2}$ can also be prepared using ball-milling of $\mathrm{LiBH}_{4}$ and $\mathrm{EuCl}_{2}$ or $\mathrm{EuCl}_{3}$ with or without purification/solvent extraction [212]. Several polymorphs have been reported: $o-\mathrm{Eu}\left(\mathrm{BH}_{4}\right)_{2}$, which transforms to $t-\mathrm{Eu}\left(\mathrm{BH}_{4}\right)_{2}$ upon heating at $668 \mathrm{~K}$ and coexists with $c-\mathrm{Eu}\left(\mathrm{BH}_{4}\right)_{2}$ (Table 14) [215]. This last compound is considered (probably) metastable [215]. $t$-Eu( $\left(\mathrm{BH}_{4}\right)_{2}$ melts at $698 \mathrm{~K}$. Humphries et al. identified an amorphization process at $461 \mathrm{~K} \mathrm{[212].} \mathrm{Eu}\left(\mathrm{BH}_{4}\right)_{2}$ presents a single emission band at $463 \mathrm{~nm}$ [215]. Decomposition of $\mathrm{Eu}\left(\mathrm{BH}_{4}\right)_{2}$ at $668 \mathrm{~K}$ is reported as a complex process, with the initial thermal decomposition described as [215]:

$$
2 \mathrm{Eu}\left(\mathrm{BH}_{4}\right)_{2} \rightarrow \mathrm{Eu}_{2}\left(\mathrm{BH}_{4}\right) \mathrm{H}_{3}+\mathrm{B}_{3} \mathrm{H}_{9}
$$

\begin{tabular}{|c|c|c|c|}
\hline $\begin{array}{l}\text { Material and Hydrogen } \\
\text { Content [wt.\%] }\end{array}$ & Structural Parameters $\left[\AA{ }^{\circ}{ }^{\circ}\right]$ & Atomic Positions & $\begin{array}{l}\text { References and } \\
\text { Comments }\end{array}$ \\
\hline $\begin{array}{c}o-\mathrm{Eu}\left(\mathrm{BH}_{4}\right)_{2} \\
4.44\end{array}$ & $\begin{array}{l}\text { Space group: orthorhombic } \\
\text { Pbcn (60) } \\
\mathrm{a}=6.90343(16), \mathrm{b}= \\
8.37272(18), \mathrm{c}=7.48321(16) \\
\alpha=\beta=\gamma=90\end{array}$ & $\begin{array}{c}\text { Eu: } 0,0.15042(20), 0.25 . \text { B: } \\
\text { 0.2459(21), 0.3837(31),0.4335(21). } \\
\text { H1: } 0.327(11), 0.280(8), 0.352(11) \\
\text { H2: } 0.138(11), 0.325(10), 0.540(10) \\
\text { H3: } 0.155(12), 0.465(9), 0.332(11) \\
\text { H4: } 0.363(10), 0.464(9), 0.509(13)\end{array}$ & [212] \\
\hline$t-\mathrm{Eu}\left(\mathrm{BH}_{4}\right)_{2}$ & $\begin{array}{c}\text { Space group: tetragonal } \\
P 4_{1} 2_{1} 2(92) \\
\mathrm{a}=5.4091(6), \mathrm{b}=5.4091(6), \mathrm{c}= \\
11.6201(17) \\
\alpha=\beta=\gamma=90\end{array}$ & $\begin{array}{c}\text { Eu1: } 0.0627(16), 0.0624(16), 0 . \text { B2: } \\
0.9401,0.4249,0.3648 . \text { H3: } 0.0998 \\
0.4164,0.4199 . \text { H4: } 0.9590,0.58450 \\
\text { 0.3101. H5: } 0.9311,0.2550,0.3159 \\
\text { H6: } 0.7705,0.4436,0.41330\end{array}$ & [215] \\
\hline $\begin{array}{c}c-\mathrm{Eu}\left(\mathrm{BH}_{4}\right)_{2} \\
4.44\end{array}$ & 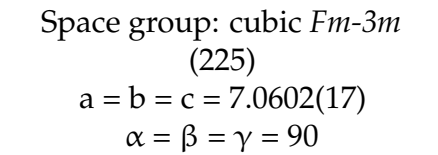 & $\begin{array}{c}\text { Eu1: } 0,0,0 . \text { B2: } 0.25,0.25,0.25 \text {. } \\
\text { H3: } 0.15789,0.15716,0.34228\end{array}$ & [215] \\
\hline
\end{tabular}

Table 14. Crystal structures of Eu-borohydrides.

$\mathrm{Eu}_{2}\left(\mathrm{BH}_{4}\right) \mathrm{H}_{3}$ melts at $698 \mathrm{~K}$; its crystalline structure is reported in [215].

Another way to reduce the dehydrogenation temperature of actinide borohydrides is through the production of mixtures. For example, a ball-milled mixture of $\mathrm{EuCl}_{3}+6 \mathrm{LiBH}_{4}$ (i.e., $\mathrm{Eu}\left(\mathrm{BH}_{4}\right)_{2}, \mathrm{LiBH}_{4}$, and $\mathrm{LiCl}$ ) decomposed between approximately 348 and $398 \mathrm{~K}$ (as observed in a TG/DSC plot) [214].

The synthesis of $\mathbf{E u}\left(\mathbf{B H}_{4}\right)_{3}$ was achieved only recently, by way of mechanical milling at low temperatures, 77-273 K, and a large excess of $\mathrm{LiBH}_{4}$ [7]. Two polymorphs of $\mathrm{Eu}\left(\mathrm{BH}_{4}\right)_{3}$ were produced [7]:

$$
\begin{gathered}
\mathrm{EuCl}_{3}+3 \mathrm{LiBH}_{4} \rightarrow \alpha-\mathrm{Eu}\left(\mathrm{BH}_{4}\right)_{3}+3 \mathrm{LiCl} \\
\mathrm{EuCl}_{3}+12 \mathrm{LiBH}_{4} \rightarrow \beta-\mathrm{Eu}\left(\mathrm{BH}_{4}\right)_{3}+3 \mathrm{LiCl}+9 \mathrm{LiBH}_{4}
\end{gathered}
$$

The $\mathrm{Eu}\left(\mathrm{BH}_{4}\right)_{3}$ polymorphs are unstable at room temperature, and compared to other $\mathrm{RE}\left(\mathrm{BH}_{4}\right)_{3}$ decomposition products; $\mathrm{Eu}\left(\mathrm{BH}_{4}\right)_{3}$ decomposition did not involve the formation of $\mathrm{Eu}\left(\mathrm{BH}_{4}\right)_{2}$. Wegner et al. explain this peculiarity as due to the redox potential of the $\mathrm{Eu}^{+3} / \mathrm{Eu}^{+2}$ pair [7].

Other compounds with Eu and $\left[\mathrm{BH}_{4}\right]^{-1}$ ligands have been reported, but their existence was not corroborated due to poor characterization or synthesis details. Halide substitution was reported as early as 1966; $\mathrm{EuBr}\left(\mathrm{BH}_{4}\right)$ was produced by the reaction of $\mathrm{EuBr}_{2}$ (reduced 
in-situ from $\left.\mathrm{EuBr}_{3}\right)$ and $\mathrm{LiBH}_{4}$ in THF [216]. In a 1999 report, $\mathrm{NaEu}\left(\mathrm{BH}_{4}\right)_{4} \cdot 4 \mathrm{DME}$ was used as a precursor to $\mathrm{Eu}\left(\mathrm{BH}_{4}\right)_{2}$ [217]. $\mathbf{C s E u}\left(\mathbf{B H}_{4}\right)_{3}$ was reported recently (with few details of its synthesis); it shows intense blue luminescence centered around $485 \mathrm{~nm}$, which is $20 \mathrm{~nm}$ red-shifted from $\mathrm{Eu}\left(\mathrm{BH}_{4}\right)_{2}$ [69]. $\mathbf{R b E u}\left(\mathbf{B H}_{4}\right)_{3}$ was also briefly mentioned in a recent report as having luminescence properties [69].

Reports on gadolinium borohydrides indicated a rich chemistry, several different crystal structures (Table 15), and structural modifications by means of double cation or anion substituted materials. Ball-milling produced $\mathbf{G d}\left(\mathbf{B H}_{4}\right)_{3}(+3 \mathrm{LiCl})$ presented two relevant endothermic processes upon heating: (i) at $484 \mathrm{~K}$ (peak temperature), a phase transition to a high-temperature $\mathrm{Gd}\left(\mathrm{BH}_{4}\right)_{3}$ polymorph (cubic structure with a $=11.418$ $\AA$ [218]). (ii) Decomposition started at $503 \mathrm{~K}$, with a peak temperature at $531 \mathrm{~K}$ [218]. Among the dehydrogenation products, $\mathrm{GdB}_{4}$ [7] and $\mathrm{GdH}_{2}$ were observed; thus, two dehydrogenation reactions were proposed [218]:

$$
\begin{gathered}
\mathrm{Gd}\left(\mathrm{BH}_{4}\right)_{3} \rightarrow 0.25 \mathrm{GdH}_{2}+0.75 \mathrm{GdB}_{4}+5.75 \mathrm{H}_{2} \\
\mathrm{Gd}\left(\mathrm{BH}_{4}\right)_{3} \rightarrow \mathrm{GdH}_{2}+3 \mathrm{~B}+5 \mathrm{H}_{2}
\end{gathered}
$$

\begin{tabular}{|c|c|c|c|}
\hline $\begin{array}{l}\text { Material and Hydrogen } \\
\text { Content [wt.\%] }\end{array}$ & Structural Parameters $\left[\AA \AA^{\circ}{ }^{\circ}\right]$ & Atomic Positions & Reference and Comments \\
\hline$\underset{5.99}{\alpha-\mathrm{Gd}\left(\mathrm{BH}_{4}\right)_{3}}$ & $\begin{array}{l}\text { Space group: cubic } \mathrm{Pa}-3 \text { (205) } \\
\qquad \begin{array}{c}\mathrm{a}=\mathrm{b}=\mathrm{c}=11.008 \\
\alpha=\beta=\gamma=90\end{array}\end{array}$ & $\begin{array}{c}\text { Gd: } 0.2169,0.2169,0.2169 . \text { B: } 0.1919,0.2475 \\
0.9670 \text {. H1: } 0.2892,0.2539,0.0231 \text {. H2: } 0.1039 \\
0.2248,0.0335 . \text { H3: } 0.1736,0.3472,0.9186 . \text { H4: } \\
0.2012,0.1633,0.8931\end{array}$ & $\begin{array}{c}\text { Theoretical calculation (predicted } \\
\text { DFT). [53] }\end{array}$ \\
\hline$\underset{6.51}{\mathrm{~K}_{2} \mathrm{Gd}\left(\mathrm{BH}_{4}\right)_{5}}$ & $\begin{array}{l}\text { Space group: monoclinic } P 21 / m(11) \\
\quad \begin{array}{c}a=8.7001(3), b=12.1241(5), c= \\
11.9893(5)\end{array} \\
\alpha=90, \beta=105.009(1), \gamma=90\end{array}$ & 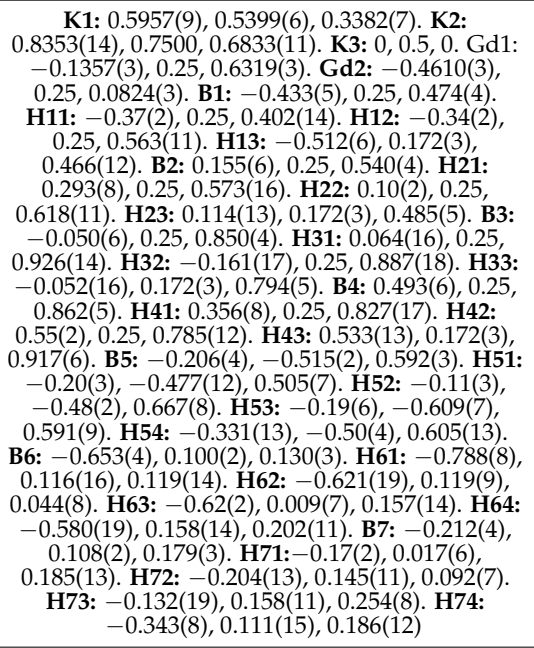 & [20] experimental $298 \mathrm{~K}$ \\
\hline $\begin{array}{l}\mathrm{KGd}\left(\mathrm{BH}_{4}\right)_{4} \\
6.31\end{array}$ & $\begin{array}{l}\text { Space group: monoclinic } P 2_{1} / c(14) \\
\begin{array}{c}a=7.1051(6), b=7.7365(6), c= \\
8.1049(6) \\
\alpha=\gamma=90, \beta=102.192(4)\end{array}\end{array}$ & $\begin{array}{c}\text { K1: } 0.5,0,0.5 \text {. Gd1: } 0,0.5,0.5 . \text { B1: }-0.107(8), \\
0.771(7), 0.328(7) \text {. H11: }-0.10(6), 0.71(3), 0.46(2) \text {. } \\
\text { H12: } 0.01(6), 0.70(6), 0.27(4) \text {. H13: }-0.07(11), \\
0.92(2), 0.34(5) . \text { H14: }-0.26(3), 0.75(10), 0.24(4) \\
\text { B2: } 0.653(8), 0.146(5), 0.900(7) . \text { H21: } 0.56(3), \\
0.27(2), 0.92(3) . \text { H22: } 0.55(3), 0.03(2), 0.86(3) \\
\text { H23: } 0.76(3), 0.12(3), 1.027(18) . \text { H24: } 0.74(3), \\
0.17(3), 0.80(2)\end{array}$ & [20] experimental $450 \mathrm{~K}$ \\
\hline $\begin{array}{c}\mathrm{Cs}_{3} \mathrm{Gd}\left(\mathrm{BH}_{4}\right)_{6} \\
3.75\end{array}$ & $\begin{array}{c}\text { Space group: cubic } F 23 \text { (196) } \\
\mathrm{a}=\mathrm{b}=\mathrm{c}=11.3000(1), \alpha=\beta=\gamma=90\end{array}$ & $\begin{array}{c}\text { Cs1: 0, 0, 0. Cs2: } 0,0.5,0 . \text { Cs3: } 0.75,0.75,0.75 \text {. } \\
\text { Gd: 0.2503, 0.7495, 0.7483. B: 0.7498, 0.7499, } \\
\text { 0.4965. H1: } 0.8059,0.8100,0.5550 . \text { H2: } 0.6900 \\
0.8062,0.4380\end{array}$ & [20] experimental $298 \mathrm{~K}$ \\
\hline
\end{tabular}

Table 15. Crystal structures of Gd-borohydrides.

Solvated gadolinium borohydride, $\mathrm{Gd}\left(\mathrm{BH}_{4}\right)_{3} \cdot \mathrm{S}\left(\mathrm{CH}_{3}\right)_{2}$, released $\mathrm{S}\left(\mathrm{CH}_{3}\right)_{2}$ upon heating at $408 \mathrm{~K}$ (peak temperature) [219], and then decomposed at $508 \mathrm{~K}$ [14]-543 K [17], with a small release of $\mathrm{B}_{2} \mathrm{H}_{3}$ [219].

Several double cation Gd-borohydrides have been reported: $\mathbf{N a G d}\left(\mathbf{B H}_{4}\right)_{4}$ was formed after heat treatment of $\mathrm{NaBH}_{4}-\mathrm{Gd}\left(\mathrm{BH}_{4}\right)_{3}$; it was so amorphous and unstable that it decomposed at RT in one day [204]. $\mathbf{A}_{\mathbf{n}} \mathbf{G d}\left(\mathbf{B H}_{4}\right)_{\mathbf{n}+3}, \mathbf{A}=\mathbf{K}$, and $\mathbf{C s}$, were produced by ball-milling mediated addition reactions between $\mathrm{KBH}_{4}$ or $\mathrm{CsBH}_{4}$ and $\mathrm{Gd}\left(\mathrm{BH}_{4}\right)_{3}$; the 
available crystallographic information is collected in Table $15[20,69,204]$. The structure of $\mathrm{Cs}_{3} \mathbf{G d}\left(\mathbf{B H}_{4}\right)_{6}$ is double-perovskite-type with luminescence properties [69].

Cation- and anion-substituted $\mathrm{LiGd}\left(\mathrm{BH}_{4}\right)_{3} \mathrm{Cl}$ can be produced as a by-product of mechanical milling and further heating to $466 \mathrm{~K}$ of $\mathrm{GdCl}_{3}$ and $\mathrm{LiBH}_{4}$ [14]:

$$
\mathrm{Gd}\left(\mathrm{BH}_{4}\right)_{3}+\mathrm{LiCl} \rightarrow \mathrm{LiGd}\left(\mathrm{BH}_{4}\right)_{3} \mathrm{Cl}
$$

LiGd $\left(\mathrm{BH}_{4}\right)_{3} \mathrm{Cl}$ possesses high Li-ion conductivity at $293 \mathrm{~K} ; 3.5 \times 10^{-4} \mathrm{~S} \mathrm{~cm}^{-1}$ [14]. Decomposition of $\mathrm{LiGd}\left(\mathrm{BH}_{4}\right)_{3} \mathrm{Cl}$ was reported at $534 \mathrm{~K}$ to form $\mathrm{GdH}_{2}, \mathrm{GdB}_{4}, \mathrm{H}_{2}$, and $\mathrm{LiCl}$. Essentially, there is no difference in dehydrogenation products as compared to other millings of $\mathrm{GdCl}_{3} / \mathrm{LiBH}_{4}$ or reactive mixtures.

The reactive mixture of Gennari et al., $\mathrm{Gd}\left(\mathrm{BH}_{4}\right)_{3}+3 \mathrm{LiBH}_{4}+3 \mathrm{LiCl}$ (from mechanical milled $6 \mathrm{LiBH}_{4}+\mathrm{GdCl}_{3}$ ), present similarities with the analogous mixture with Ce; dehydrogenation is a multistep process, with hydrogen desorption occurring at $493 \mathrm{~K}, 548 \mathrm{~K}$, and 588K [210]. Among the dehydrogenation products, crystalline $\mathrm{GdB}_{4}$ and $\mathrm{GdH}_{2}$ were identified [210]. The proposed dehydrogenation pathway is, first, the decomposition of $\mathrm{Gd}\left(\mathrm{BH}_{4}\right)_{3}$ to produce $\mathrm{GdH}_{2}, \mathrm{GdB}_{4}$, and $\mathrm{H}_{2}$; then, $\mathrm{GdH}_{2}$ reacts with $\mathrm{LiBH}_{4}$ to produce additional $\mathrm{GdB}_{4}$ and $\mathrm{H}_{2}$, as well as $\mathrm{LiH}$ [210]. In line with the possible formation of $\mathrm{LiRE}\left(\mathrm{BH}_{4}\right)_{3} \mathrm{Cl}$ during the ball-milling of 6:1 mixtures of $\mathrm{LiBH}_{4}$ and $\mathrm{RECl}_{3}$, Olsen et al. proposed another general dehydrogenation reaction occurring in this kind of reactive mixture [214]:

$$
\mathrm{LiRE}\left(\mathrm{BH}_{4}\right)_{3} \mathrm{Cl}+3 \mathrm{LiBH}_{4} \rightarrow \mathrm{LiCl}+\mathrm{REB}_{6}+3 \mathrm{LiH}+(21 / 2) \mathrm{H}_{2}
$$

Partial rehydrogenation of the dehydrogenated $\mathrm{Gd}\left(\mathrm{BH}_{4}\right)_{3}+3 \mathrm{LiBH}_{4}+3 \mathrm{LiCl}$ mixture was achieved at $673 \mathrm{~K}$ and $6 \mathrm{MPa}$ [210].

For the late lanthanide borohydrides of $\mathrm{RE}=\mathrm{Tb}, \mathrm{Dy}, \mathrm{Ho}, \mathrm{Er}, \mathrm{Tb}, \mathrm{Tm}, \mathrm{Yb}$, and $\mathrm{Lu}$, the synthesis is the same as that described above, i.e., pre-milled $\mathrm{REH}_{3}$ reacted with dimethyl sulfide-borane in toluene at $318 \mathrm{~K}$ for up to seven days, followed by solvent extraction [13]. Yet, mechanical milling of $\mathrm{LiBH}_{4}$ and $\mathrm{RECl}_{3}$ can also be an option, with or without temperature control [7]. The $\alpha$ - and $\beta-\mathrm{RE}\left(\mathrm{BH}_{4}\right)_{3}$ polymorphs share the same cubic group symmetry, $\alpha: P a-3$, and $\beta: F m-3$ [13], with smooth size changes of the crystallographic cell upon the cation radii [7]. In the mechanical-milling route, an excess of $\mathrm{LiBH}_{4}$ favors the formation of the $\beta-\mathrm{RE}\left(\mathrm{BH}_{4}\right)_{3}$ polymorph [7]. Wegner et al. reported that most of the $\mathrm{RE}\left(\mathrm{BH}_{4}\right)_{3}$ prepared by mechanical milling decomposed with the fasted rate at $523 \mathrm{~K}$, producing very pure hydrogen [7]. The decomposition products of $\mathrm{RE}\left(\mathrm{BH}_{4}\right)_{3}$ have the formation of $\mathrm{REB}_{4}$ in common, except for the Lu-containing compound, which forms $\mathrm{LuB}_{2}$ [7].

Two Ho-borohydrides have been reported- $\mathbf{H o}\left(\mathbf{B H}_{4}\right)_{3}$ and $\mathbf{K H o}\left(\mathbf{B H}_{4}\right)_{4}[220] . \mathrm{Ho}\left(\mathrm{BH}_{4}\right)_{3}$ behaved like the usual $\mathrm{RE}\left(\mathrm{BH}_{4}\right)_{3}$ compounds described above, i.e., this material presents two polymorphs, $\alpha$ - and $\beta$-, whose relative amount depends on the excess of $\mathrm{LiBH}_{4}$ during the ball milling [220]. The peak decomposition temperature of $523 \mathrm{~K}$ was preceded by two smaller endothermic peaks [220]. $\mathrm{KHo}\left(\mathrm{BH}_{4}\right)_{4}$ was prepared by means of the solid-state reaction [220]:

$$
\mathrm{HoCl}_{3}+3 \mathrm{LiBH}_{4}+\mathrm{KBH}_{4} \rightarrow \mathrm{KHo}\left(\mathrm{BH}_{4}\right)_{4}+3 \mathrm{LiCl}
$$

$\mathrm{KHo}\left(\mathrm{BH}_{4}\right)_{4}$ crystallizes in an orthorhombic lattice $(\mathrm{Cmcm})$. Upon heating, this material melts at $448 \mathrm{~K}$, and decomposition occurs at $531 \mathrm{~K}$ [220].

$\mathrm{Er}\left(\mathbf{B H}_{4}\right)_{3}$ (from ball-milling $\mathrm{ErCl}_{3}+3 \mathrm{LiBH}_{4}$, extraction with solvent and heat treatment) decomposed at $559 \mathrm{~K}$ (peak temperature), with low $\mathrm{B}_{2} \mathrm{H}_{6}$ emission [211]. Rehydrogenation at $613 \mathrm{~K}, 10 \mathrm{MPa}$ hydrogen pressure during $21 \mathrm{~h}$ did not succeed [211]. $\mathrm{NaEr}\left(\mathrm{BH}_{4}\right)_{4}$ was formed by the assisted ball-milled reaction between $\mathrm{NaBH}_{4}$ and $\mathrm{Er}\left(\mathrm{BH}_{4}\right)_{3}$ (crystal structure at Table 16) [204]. Melting was observed between $427 \mathrm{~K}$ and $435 \mathrm{~K}$. 
Table 16. Crystal structures of Er-borohydrides.

\begin{tabular}{|c|c|c|c|}
\hline $\begin{array}{l}\text { Material and Hydrogen } \\
\text { Content [wt. \%] }\end{array}$ & Structural Parameters $\left[\AA^{\circ},{ }^{\circ}\right]$ & Atomic Positions & Comments \\
\hline $\begin{array}{c}\mathrm{NaEr}\left(\mathrm{BH}_{4}\right)_{4} \\
6.46\end{array}$ & $\begin{array}{l}\text { Space group: orthorhombic } \\
\text { Cmcm (63) } \\
\begin{array}{c}\mathrm{a}=8.5379(2), \mathrm{b}=12.1570(4), \\
\mathrm{c}=9.1652(3) \\
\alpha=\beta=\gamma=90\end{array}\end{array}$ & $\begin{array}{c}\text { Na11: 0, 0, 0.5. Er12: } 0.5 \\
\text { 0.1430, 0.75. B13: 0.5, 0.2630, } \\
\text { 0.9630. H14: 0.5, 0.3200, } \\
\text { 0.0640. H15: 0.5, 0.1720, } \\
\text { 1.0020. H16: 0.6113, 0.2800, } \\
\text { 0.8930. B17: } 0.7390,0.0410, \\
\text { 0.75. H18: 0.8660, 0.0060, } 0.75 \text {. } \\
\text { H19: } 0.7440,0.1360,0.75 . \\
\text { H110: } 0.6730,0.0110,0.85368\end{array}$ & [204] \\
\hline
\end{tabular}

$\mathrm{Yb}$ (as in the case of $\mathrm{Sm}$ and $\mathrm{Eu}$ ) can form $\mathbf{Y b}\left(\mathbf{B H}_{4}\right)_{2}$ by the reduction in $\mathbf{Y b}\left(\mathbf{B H}_{4}\right)_{3}$ [7]:

$$
2 \mathrm{Yb}\left(\mathrm{BH}_{4}\right)_{3} \rightarrow 2 \mathrm{Yb}\left(\mathrm{BH}_{4}\right)_{2}+\mathrm{B}_{2} \mathrm{H}_{6}+\mathrm{H}_{2}
$$

Ytterbium (II) borohydride has four reported polymorphs: $\alpha-\mathrm{Yb}\left(\mathrm{BH}_{4}\right)_{2}, \alpha^{\prime}-\mathrm{Yb}\left(\mathrm{BH}_{4}\right)_{2}$, $\beta-\mathrm{Yb}\left(\mathrm{BH}_{4}\right)_{2}$, and $\gamma-\mathrm{Yb}\left(\mathrm{BH}_{4}\right)_{2}$ (Table 17) [17]. For their part, the Ytterbium (III) borohydrides $\alpha-\mathrm{Yb}\left(\mathrm{BH}_{4}\right)_{3}$ and $\beta-\mathrm{Yb}\left(\mathrm{BH}_{4}\right)_{3}$ can be produced by mechanical milling of $3 \mathrm{LiBH}_{4}$ and $\mathrm{YbCl}_{3}$ [198]. $\alpha-\mathrm{Yb}\left(\mathrm{BH}_{4}\right)_{3}$ is isostructural to the low temperature $\alpha-\mathrm{Y}\left(\mathrm{BH}_{4}\right)_{3}$; however, $\beta-\mathrm{Yb}\left(\mathrm{BH}_{4}\right)_{3}$ is not similar to the high-temperature polymorph of $\mathrm{Y}\left(\mathrm{BH}_{4}\right)_{3}$ (Table 17) [198] because of a disordered $\left[\mathrm{BH}_{4}\right]^{-1}$ orientation. $\alpha-\mathrm{Yb}\left(\mathrm{BH}_{4}\right)_{3}$ and $\beta-\mathrm{Yb}\left(\mathrm{BH}_{4}\right)_{3}$ can coexist because the two modifications are close in energy [198]. Decomposition of $\mathrm{Yb}\left(\mathrm{BH}_{4}\right)_{3}$ occurred in two steps: the first one at $418 \mathrm{~K}$ and the second at $618 \mathrm{~K}$ (temperature of maximum gas evolution) [198]. As in other RE-borohydrides, chlorine substituted Yb-borohydrides have been reported: $\mathbf{L i} \mathbf{Y b}\left(\mathbf{B H}_{4}\right)_{4-\mathbf{x}} \mathbf{C l}_{\mathbf{x}}$ and $\mathbf{Y b}\left(\mathbf{B H}_{4}\right)_{2-\mathbf{x}} \mathbf{C l}_{\mathbf{x}}$ [198].

Table 17. Crystal structures of Yb-borohydrides.

\begin{tabular}{|c|c|c|c|}
\hline $\begin{array}{c}\text { Material and Hydrogen } \\
\text { Content [wt. \%] }\end{array}$ & Structural Parameters $\left[\AA{ }^{\circ}\right]$ & Atomic Positions & Comments \\
\hline $\begin{array}{c}\alpha-\mathrm{Yb}\left(\mathrm{BH}_{4}\right)_{2} \\
5.56\end{array}$ & $\begin{array}{l}\text { Space group: cubic } \mathrm{Pa}-3 \text { (205) } \\
\qquad \begin{array}{c}\mathrm{a}=\mathrm{b}=\mathrm{c}=10.70715(15) \\
\alpha=\beta=\gamma=90\end{array}\end{array}$ & $\begin{array}{c}\text { Yb: } 0.71615(5), 0.71615(5), 0.71615(5) . \\
\text { B: }-0.0391(12), 0.6968(11), 0.7536(18) \\
\text { H1: }-0.104(6), 0.640(6), 0.684(6) . \text { H2: } \\
0.064(3), 0.652(5), 0.753(8) . \text { H3: } \\
-0.079(7), 0.693(7), 0.857(3) . \text { H4: } \\
\quad-0.031(6), 0.803(2), 0.720(7)\end{array}$ & [198] \\
\hline $\begin{array}{c}\beta-\mathrm{Yb}\left(\mathrm{BH}_{4}\right)_{2} \\
5.56\end{array}$ & $\begin{array}{l}\text { Space group: cubic Pm-3m } \\
\qquad \begin{array}{c}\text { (221) } \\
\mathrm{a}=\mathrm{b}=\mathrm{c}=5.44223(3) \\
\alpha=\beta=\gamma=90\end{array}\end{array}$ & $\begin{array}{c}\text { Yb: } 0,0,0 . \mathbf{B}: \frac{1}{2}, 0,0 . \mathbf{H}: 0.3745(4), 0 \\
0.1826(3)\end{array}$ & [198] \\
\hline
\end{tabular}

Mechanically milled $\mathrm{LiYb}\left(\mathrm{BH}_{4}\right)_{4}$ and $\mathrm{NaYb}\left(\mathrm{BH}_{4}\right)_{4}$ were briefly mentioned in a recent report; they presented lower Auzel's crystal field strength properties as compared to $\mathrm{Tb}, \mathrm{Dy}$, Tm, and Ho-borohydrides [19]. $\mathbf{N a} \mathbf{Y b}\left(\mathbf{B H}_{4}\right)_{4}$ and $\mathbf{K Y b}\left(\mathbf{B H}_{4}\right)_{4}$ were produced by a reaction analogous to (106); both compounds are isostructural to $\mathrm{NaSc}\left(\mathrm{BH}_{4}\right)_{4}$ and $\mathrm{KY}\left(\mathrm{BH}_{4}\right)_{4}$, i.e., orthorhombic Cmcm space group [221].

\subsection{Actinides}

Some of the actinide borohydrides were first synthesized during the Manhattan Project [222]. Today, the interest on actinide homoleptic borohydrides has notably decreased, yet they are summarized in this section. Actinide borohydrides, from $\mathrm{Th}$ to $\mathrm{Pu}$, are volatile molecules near room temperature. $\mathrm{Th}\left(\mathrm{BH}_{4}\right)_{4}, \mathrm{~Pa}\left(\mathrm{BH}_{4}\right)_{4}$, and $\mathrm{U}\left(\mathrm{BH}_{4}\right)_{4}$ are isomorphic, and their volatility increases with the increasing atomic number, whereas $\mathrm{Np}\left(\mathrm{BH}_{4}\right)_{4}$ and $\mathrm{Pu}\left(\mathrm{BH}_{4}\right)_{4}$ resemble the $\mathrm{Zr}$-borohydride [223]. Additionally, $\mathrm{Th}, \mathrm{Pa}$, and $\mathrm{U}$ borohydrides 
have double-bridged $\left[\mathrm{BH}_{4}\right]^{-1}$ groups that link metal atoms in a low-symmetry polymeric structure in the crystalline phase [223,224].

$\mathbf{T h}\left(\mathbf{B H}_{4}\right)_{4}$ was produced in the Th-analogous reaction (109) at room temperature [72], and crystallized in the tetragonal $P_{3}{ }_{2}{ }_{1} 2$ space group. It is a polymeric material, melting at $476 \mathrm{~K}$ [222].

$\mathrm{Pa}\left(\mathrm{BH}_{4}\right)_{4}$ was produced by the following reaction in the absence of solvent, followed by heating to $328 \mathrm{~K}$, and recovered by condensation in a cold tramp at $273 \mathrm{~K}$ [222]:

$$
\mathrm{PaF}_{4}+2 \mathrm{Al}\left(\mathrm{BH}_{4}\right)_{3(l)} \rightarrow \mathrm{Pa}\left(\mathrm{BH}_{4}\right)_{4}+2 \mathrm{AlF}_{2} \mathrm{BH}_{4}
$$

$\mathrm{Pa}\left(\mathrm{BH}_{4}\right)_{4}$ behaves like $\mathrm{U}\left(\mathrm{BH}_{4}\right)_{4}$ and $\mathrm{Th}\left(\mathrm{BH}_{4}\right)_{4}$ [222].

$\mathbf{U}\left(\mathbf{B H}_{4}\right)_{4}$ was first produced during the Manhattan Project [225]. It can be prepared by stirring $\mathrm{UCl}_{4}$ and an excess of $\mathrm{LiBH}_{4}$ at room temperature for two weeks [81]. Old reports indicate that the reaction of $\mathrm{UF}_{4}$ with liquid $\mathrm{Al}\left(\mathrm{BH}_{4}\right)_{3}$ (Equation (109)) produces the uranium borohydride [226,227]. $\mathrm{U}\left(\mathrm{BH}_{4}\right)_{4}$, being volatile at room temperature, can be collected in a cold tramp and also purified in this way [81]. $\mathrm{U}\left(\mathrm{BH}_{4}\right)_{4}$ forms lustrous dark-green crystals; it is polymeric in the solid-state and monomeric in the gas phase [228]. $\mathrm{U}\left(\mathrm{BH}_{4}\right)_{4}$ crystallizes in the tetragonal $\mathrm{P}_{3} 2_{1} 2$ space group, and its melting point is $399 \mathrm{~K}$ [222]. $\mathrm{U}\left(\mathrm{BH}_{4}\right)_{4}$ possesses high symmetry $\left(T_{d}\right)$, efficient screening of the metal atom, and the limited bridging ability of the $\left[\mathrm{BH}_{4}\right]^{-1}$ ion [81]. The optical spectrum of $\mathrm{U}\left(\mathrm{BH}_{4}\right)_{4}$ can be revised at $[223,227]$ and, relatively recently, the f-orbital covalency in $\mathrm{U}\left(\mathrm{BH}_{4}\right)_{4}$ was demonstrated [87]. $\mathrm{U}\left(\mathrm{BH}_{4}\right)_{4}$ is fairly stable at room temperature [229], but can decompose upon the action of ultraviolet photons of $253.5 \mathrm{~nm}(4.8 \mathrm{eV})$ at $295 \mathrm{~K}$, with $\mathrm{B}_{2} \mathrm{H}_{6}$ being a decomposition product [228]:

$$
2 \mathrm{U}\left(\mathrm{BH}_{4}\right)_{4} \rightarrow 2 \mathrm{U}\left(\mathrm{BH}_{4}\right)_{3}+\mathrm{B}_{2} \mathrm{H}_{6}+\mathrm{H}_{2}
$$

or

$$
\mathrm{U}\left(\mathrm{BH}_{4}\right)_{4} \rightarrow \mathrm{U}\left(\mathrm{BH}_{4}\right)_{2}+\mathrm{B}_{2} \mathrm{H}_{6}+\mathrm{H}_{2}
$$

Thermal decomposition of $\mathrm{U}\left(\mathrm{BH}_{4}\right)_{4}$ was reported in 1981; Ghiassee et al. followed the decomposition of $\mathrm{U}\left(\mathrm{BH}_{4}\right)_{4}$, utilizing infrared spectroscopy in the gas phase [229]. $\mathrm{U}\left(\mathrm{BH}_{4}\right)_{4}$ decomposes thermally in two ranges of temperature: at $373 \mathrm{~K}$, the proposed reaction is (109) $[226,229,230]$; at a temperature superior to $423 \mathrm{~K}$, decomposition is rapid with the formation of a black-silver mirror [229]:

$$
\mathrm{U}\left(\mathrm{BH}_{4}\right)_{4} \rightarrow \mathrm{U}+4 \mathrm{~B}+8 \mathrm{H}_{2}
$$

Decomposition kinetics was of first-order between 403 and $443 \mathrm{~K}$ and of second-order between 373 and $393 \mathrm{~K}$ [229].

$\mathbf{N p}\left(\mathbf{B H}_{4}\right)_{3}$ is a dark green, pyrophoric, volatile, and reactive liquid that decomposes at $298 \mathrm{~K}$ [225], and whose physical properties resemble those of $\mathrm{Hf}$ and $\mathrm{Zr}$ borohydrides. Its optical spectrum was reported in detail in [231]. $\mathrm{Np}\left(\mathrm{BH}_{4}\right)_{3}$ was produced in a reaction type analogous to (108), but is unstable at room temperature, so that the reaction was carried out at $273 \mathrm{~K}$ [222]. $\mathrm{Np}\left(\mathrm{BH}_{4}\right)_{3}$ crystallizes in the tetragonal $P 4_{2} / n m c$ space group; structural single-crystal studies were performed at $130 \mathrm{~K}$. The melting point is $287 \mathrm{~K}$ and the boiling point is $426 \mathrm{~K}$ [222].

$\mathbf{P u}\left(\mathrm{BH}_{4}\right)_{3}$ is also an unstable and volatile compound; its synthesis was similar to that of $\mathrm{Np}\left(\mathrm{BH}_{4}\right)_{3}$ [222]. $\mathrm{Pu}\left(\mathrm{BH}_{4}\right)_{3}$ melts at $287 \mathrm{~K}$ and decomposes roughly at $293 \mathrm{~K}$ [225].

\section{Thermodynamics (Thermal Stability)}

As with any hydrogen storage material, formation enthalpy is the best predictor of a borohydride's stability [232]. However, such information is only available for a small number of borohydrides. Because of that, other predictors have been considered. 
Nakamori et al. proposed an equation that relates the Pauling electronegativity, $\chi_{P}$, of the metal counter-ion with the formation enthalpy (per $\left[\mathrm{BH}_{4}\right]^{-1}$ ion) $[30,181]$ :

$$
\Delta H_{\text {boro }}=248.7 \chi_{P}-390.8
$$

However, borohydrides can form double or even triple cation compounds. Thus, an adjustment must be made to Equation (112). In a series of $\mathrm{ZrLi}_{\mathrm{m}-4}\left(\mathrm{BH}_{4}\right)_{\mathrm{m}}, \mathrm{Li}$ et al. proposed an average value of $\chi_{P}$ as a predictor of the dehydrogenation temperature [233]:

$$
\chi_{P}=\frac{1.4+1.0(m-4)}{1+(m-4)}
$$

$\mathrm{m}=0-4$, in $\mathrm{ZrLi}_{\mathrm{m}-4}\left(\mathrm{BH}_{4}\right)_{\mathrm{m}}$. However, an extension to other bi-cationic borohydrides is necessary. In Figure 9, we collected the dehydrogenation temperatures of the borohydrides (in logarithmic scale) encountered during the preparation of this review, and plotted as a function of the Pauling electronegativity. For bi-cation borohydrides of the general form $\mathrm{M} 1_{\mathrm{x}} \mathrm{M} 2_{\mathrm{y}}\left(\mathrm{BH}_{4}\right)_{\mathrm{z}}$, a weighted average was used:

$$
\chi_{P}=\frac{x * \chi_{P M 1}+y * \chi_{P M 2}}{x+y}
$$

where $\chi_{P M 1}$ and $\chi_{P M 2}$ are the Pauling electronegativities of the respective cations in the borohydride. For visual reference, some previously reported data were included. Globally, a general tendency of reducing dehydrogenation temperature with the increase in cation electronegativity is confirmed. The red line in Figure 9 indicates the fitting of all collected data:

$$
\log T=3.1529-0.3859 \chi_{p}
$$

where $\chi_{P}$ is the Pauling electronegativity of the cation, or the average (Equation (114)) for bicationic borohydrides. The r-square of Equation (115) is rather low: 0.63866 . However, it must be mentioned that there is no homogeneity in the way of reporting dehydrogenation temperatures; researchers have reported onset temperatures, peak temperatures, or ranges from the beginning and end of the reaction. Additionally, some (minor) fractions of the data were taken directly from the original plots in the reports; from DSC plots, for example. Moreover, data are reported from different techniques; for example, DSC, TGA, temperature-programmed desorption, and in-situ X-ray diffraction, and each technique shows differences in heating ramps or reaction atmospheres. Moreover, for the same borohydride, several temperatures of dehydrogenation have been reported, depending on different experimental parameters, particularly for the most studied Group I and IIborohydrides.

Other proposed predictors include the following: (i) The polarizing ability of the cationic bonding component [234], where the decreasing stability of the metal borohydride correlating with its increasing polarizing ability, as found in ab-inito studies [234]; and (ii) the relation between the Pauling electronegativity and the boron chemical NMR shift of metal borohydrides [235]. 


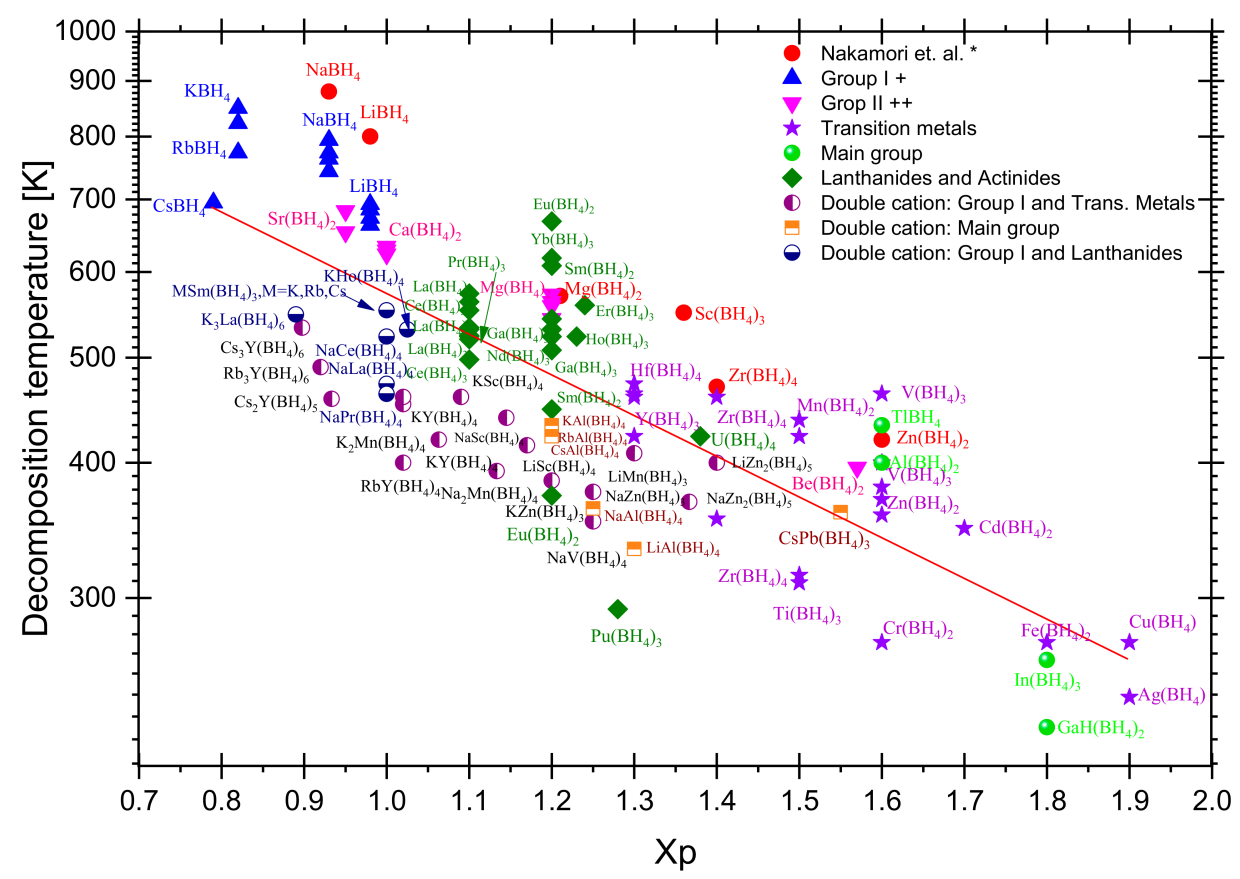

Figure 9. Compilation of dehydrogenation temperature (peak temperature whenever available, otherwise, onset temperature) versus Pauling electronegativity or weighted average Pauling electronegativity. Source data: * (red dots) Nakamori et al. (2006) [30]. + Group I borohydrides: $\mathrm{LiBH}_{4}$ [236-240], $\mathrm{NaBH}_{4}$ [241-246], $\mathrm{KBH}_{4}$ [4,247-249], $\mathrm{RbBH}_{4}$, and $\mathrm{CsBH}_{4}$ [50]. + + Group II borohydrides: $\mathrm{Be}\left(\mathrm{BH}_{4}\right)_{2}$ [250], $\mathrm{Mg}\left(\mathrm{BH}_{4}\right)_{2}$ [251-254], $\mathrm{Ca}\left(\mathrm{BH}_{4}\right)_{2}$ [255-258], and $\mathrm{Sr}\left(\mathrm{BH}_{4}\right)_{2}[215,259,260]$.

\section{The Boron Problem}

Particularly for hydrogen applications, the release of diborane and the formation of stable B-H species is a problem, as it compromises re-hydrogenation reactions. On the other hand, the release of hydrogen at low temperatures (from RT to roughly $373 \mathrm{~K}$ ) is required for compatibility with PEM (polymer exchange membrane) fuel cell applications. However, diborane release is frequently associated with the low-temperature decomposition of borohydrides. The last facts seem entirely incompatible. Yet, along with the borohydrides listed in this review, several factors appear to influence the release of diborane. These factors include, but are not limited to, the synthesis method, purification, elimination of occluded molecules with supercritical $\mathrm{N}_{2}$ processing [196], thermal history of the material, storage conditions, temperature and pressure of dehydrogenation, existence (intentional or not) of other materials such as salts, hydrides or other borohydrides, etc. Among the consulted papers, different researchers reported from null or undetectable to high amounts of diborane release for the same material. Thus, several authors have proposed theories to understand the factors influencing diborane release. Diborane release can be explained in three ways: (i) Diborane is released but decomposes at high temperatures (before being detected); (ii) diborane is an intermediary in the formation and decomposition of borohydrides; and (iii) diborane is not emitted. [261].

The accepted explanation of diborane emission during dehydrogenation reactions is that the amount of $\mathrm{B}_{2} \mathrm{H}_{6}$ released scales inversely with borohydride stability, which depends on the corresponding cation's electronegativity [262]. Callini et al. mentioned that the difference in electronegativity results in a charge transfer from the cation to the anion that destabilizes and distorts the $\left[\mathrm{BH}_{4}\right]^{-1}$ units [262]. $\left[\mathrm{BH}_{4}\right]^{-1}$ distortion can be detected and quantified utilizing infrared spectroscopy; Callini et al. proposed the stretching span $(\Delta \mathrm{s})$ as a way to classify $\mathrm{B}_{2} \mathrm{H}_{6}$-releasing borohydrides. In this approach, the stretching span is the difference in energies of the stretching vibrations of hydrogen atoms with different bonding lengths [262]. In this model, a threshold of $\Delta \mathrm{s}>200 \mathrm{~cm}^{-1}$ is proposed as the predictor of $\mathrm{B}_{2} \mathrm{H}_{6}$-releasing borohydrides; materials such as $\mathrm{LiSc}\left(\mathrm{BH}_{4}\right)_{4}$, 
$\mathrm{Zr}\left(\mathrm{BH}_{4}\right)_{4}$, and $\mathrm{Al}\left(\mathrm{BH}_{4}\right)_{3}$ will release $\mathrm{B}_{2} \mathrm{H}_{6}$, while $\mathrm{LiBH}_{4}$ will not [262]. Yet, $\mathrm{LiBH}_{4}$ releases $\mathrm{B}_{2} \mathrm{H}_{6}$ under several reaction conditions [262]. Harrison et al. mentioned that diborane production did not follow any clear trend but, for threshold values between 1.36 and 1.55 of electronegativity of the corresponding metal in the Pauling scale, $\chi_{P}$, diborane production is observed [182].

Furthermore, the dehydrogenation mechanism is frequently unresolved for transition metal borohydrides, in contrast to Group I and II borohydrides, where the formation of intermediaries such as $\mathrm{M}_{\mathrm{X}}\left(\mathrm{B}_{12} \mathrm{H}_{12}\right) \mathrm{M}=\mathrm{Li}, \mathrm{K}, \mathrm{Rb}, \mathrm{Cs}$ has been identified [263-265]. However, some models and reactions of $\mathrm{B}-\mathrm{H}$ compounds can be used to explain the dehydrogenation reaction. In the model of Callini, the distorted $\left[\mathrm{BH}_{4}\right]^{-1}$ unit is the precursor for the formation of $\left(\mathrm{H}^{\delta-}\right)_{2}$ and $\mathrm{BH}_{2}{ }^{\delta+}$, with the formation of diborane proposed as [262]:

$$
2 \mathrm{M}^{\delta 1+}+2\left(\mathrm{BH}_{4}\right)^{\delta 1-} \rightarrow 2 \mathrm{M}^{\delta 1+}+\left(\mathrm{H}^{\delta-}\right)_{2}+\mathrm{BH}_{2}{ }^{\delta 1+} \mathrm{BH}_{4}{ }^{\delta 1-} \rightarrow 2 \mathrm{M}+\mathrm{H}_{2}+\mathrm{B}_{2} \mathrm{H}_{6}
$$

Other $\mathrm{B}-\mathrm{H}$ compounds or ions have been reported from the reaction between $\mathrm{B}_{2} \mathrm{H}_{6}$ and borohydrides or hydrides in the context of studying the borane chemistry [266]:

$$
\begin{gathered}
\mathrm{B}_{2} \mathrm{H}_{6}+\mathrm{MBH}_{4} \rightarrow \mathrm{MB}_{3} \mathrm{H}_{8}+\mathrm{H}_{2} \\
\mathrm{~B}_{5} \mathrm{H}_{9}+\mathrm{MH} \rightarrow \mathrm{M}\left(\mathrm{B}_{5} \mathrm{H}_{8}\right)+\mathrm{H}_{2} \\
\mathrm{M}\left(\mathrm{B}_{5} \mathrm{H}_{8}\right)+\frac{1}{2} \mathrm{~B}_{2} \mathrm{H}_{6} \rightarrow \mathrm{M}\left(\mathrm{B}_{6} \mathrm{H}_{11}\right) \\
\mathrm{B}_{10} \mathrm{H}_{14}+\mathrm{MBH}_{4} \rightarrow \mathrm{MB}_{11} \mathrm{H}_{14}+2 \mathrm{H}_{2}, \mathrm{M}=\mathrm{Li}, \mathrm{Na}
\end{gathered}
$$

Reaction (117) requires a temperature of about $373 \mathrm{~K}$ to proceed at a reasonable rate [266]. Meanwhile, Equations (118)-(120) correspond to different reactions for a growing B-H cluster [266]. Those reactions were performed in solvent; however, some of these reactions might occur during heating of the metal borohydrides. Indeed, the formation of $\left[\mathrm{B}_{3} \mathrm{H}_{8}\right]^{-}$intermediaries in $\mathrm{Y}$ borohydride and $\left[\mathrm{B}_{12} \mathrm{H}_{12}\right]^{2-}$ in Sc borohydride [235] (and references within) has been reported. Other possible intermediaries include $\left[\mathrm{B}_{10} \mathrm{H}_{12}\right]^{2-}$ and $\left[\mathrm{B}_{11} \mathrm{H}_{14}\right]^{-}[267,268]$. For its part, the rapid dissociation of a $\mathrm{BH}_{4} \bullet$ radical into $\mathrm{BH}_{3}$ an $\mathrm{H}^{\bullet}$ above $250 \mathrm{~K}$ was predicted by means of ab-initio MO calculations [269].

It is also worth mentioning that, during the dehydrogenation of borohydrides or their composites, the formation of $\mathrm{MB}_{\mathrm{x}}$ species seems to favor re-hydrogenation $[270,271]$. In turn, the increase in back pressure during dehydrogenation favors the formation of $\mathrm{MB}_{\mathrm{x}}$ compounds [271]. Thus, a competition between the formation of metal boride compounds and $\mathrm{B}_{2} \mathrm{H}_{6}$ might be established.

Strategies for reducing the release of B-H compounds include increasing the hydrogen back-pressure during dehydrogenation [269], modification of the dehydrogenation pathway by using, for example, the formation of reactive composites [269], the use of catalysts (such as Mo(100) surface) for the decomposition of diborane [261], or other B-H intermediaries, etc.

Nano- and meso-confinement could be beneficial; until now, this was mostly employed for Group I borohydrides [272]. For example, Xia et al. reported the complete suppression of the release of $\mathrm{B}_{\mathrm{x}} \mathrm{H}_{\mathrm{y}}$ by-products and a reduction in the decomposition temperature (a decrease of about $50 \mathrm{~K}$ ) in SBA-15- confined $\mathrm{NaZn}\left(\mathrm{BH}_{4}\right)_{3}$ [159]. Stabilization of volatile $\mathrm{Ti}\left(\mathrm{BH}_{4}\right)_{3}$ was achieved by nano-confinement in MOF UiO-66 $\left(\mathrm{Zr}_{6} \mathrm{O}_{4}(\mathrm{BDC})_{6}\right.$, $\mathrm{BDC}=1$,4-benzenedicarboxylate) [76]. In this way, $\mathrm{Ti}\left(\mathrm{BH}_{4}\right)_{3}-\mathrm{UiO}-66$ was stabilized at room temperature under an argon atmosphere and, during dehydrogenation, there was no emission of diborane [76]. Instead, the decomposition involved $\mathrm{B}_{5} \mathrm{H}_{9}$ that recombined at an increased temperature to form solid higher boranes [76].

Finally, other essential data of $\left[\mathrm{BH}_{4}\right]^{-1}$ must be mentioned: the electronegativity of $\left[\mathrm{BH}_{4}\right]^{-1}$ is considered as $2.13[22,108]$, and its electron affinity is $3.18 \mathrm{eV}$ [188], while its ionic size is $2.03 \AA$ [22]. 


\section{Conclusions and Perspectives}

Beyond Groups I and II, borohydrides present interesting properties related to chemistry, structure, hydrogen release, and, in an emerging trend, ionic conductivity and photoluminescence. Among the materials reviewed in the present work the transition metals and lanthanide borohydrides stand out.

Several strategies have been tried to generate new bimetallic and trimetallic borohydrides with tailored decomposition temperatures and mechanisms of diborane release in materials intended for hydrogen storage. However, many of these new materials decompose into the "parent" borohydrides, and then high temperatures are required to release a substantial amount of hydrogen. Thus, decomposition of double or triple cation borohydrides into the "parent" borohydrides is not recommendable in the hydrogen storage area. Re-hydrogenation is still to be reached in most revised compounds. The ideal procedure would be a one-step decomposition into simple (and re-hydrogenable) compounds. To achieve this goal, several routes, such as the addition of catalysts, the use of different ligands (take advantage of organometallic chemistry), or the formation of ammonia-borane compounds, are still to be explored or are under exploration.

Additionally, the nanoconfinement of borohydrides into MOFs, polymers, zeolites, etc., could soon be a strategy for the development of new composite materials. Otherwise, porous borohydrides can be used for the confinement of $\mathrm{H}_{2}$ or other small molecules.

Anion substitution is another opportunity area that should be thoroughly studied because of the possibilities for generating new materials with high ionic conductivity for battery applications. Along with this review, we observed the formation of several $\mathrm{Cl}$-substituted borohydrides, i.e., their synthesis is facile and their niche application can be developed.

Supplementary Materials: The following are available online at https:/ /www.mdpi.com/article/10 $.3390 /$ ma14102561/s1, Figure S1: Editable version of the Figure 1. Figure S2: Editable version of the Figure 2.

Author Contributions: Conceptualization, methodology, writing-review and editing K.S.-A. Investigation, resources, data curation, J.R.T.G. All authors have read and agreed to the published version of the manuscript.

Funding: This research was funded by UNAM-PAPIIT [IN202719] Estudio sistemático de alanatos de metales de transición; síntesis y caracterización.

Institutional Review Board Statement: Not applicable.

Informed Consent Statement: Not applicable.

Data Availability Statement: The data presented in this review was collected from the cited articles.

Acknowledgments: The authors are very grateful to Teresa Vásquez Mejía for the support during the bibliographic compilation, and to G. Cabañas-Moreno for valuable discussions during the preparation of this review.

Conflicts of Interest: The authors declare no conflict of interest.

\section{References}

1. Lai, Q.; Sun, Y.; Wang, T.; Modi, P.; Cazorla, C.; Demirci, U.B.; Ramon, J.; Fernandez, A.; Leardini, F. How to Design Hydrogen Storage Materials? Fundamentals, Synthesis, and Storage Tanks. Adv. Sustain. Syst. 2019, 1900043, 1-64. [CrossRef]

2. Chem, G.; Lai, Q. Borohydrides as Solid-State Hydrogen Storage Materials: Past, Current Approaches and Future Perspectives. Gen. Chem. 2018, 4, 1-11. [CrossRef]

3. Laversenne, L. Synthesis and crystal structure of transition element borohydrides: $\mathrm{M}\left(\mathrm{BH}_{4}\right)_{\mathrm{y}}, \mathrm{M}=\mathrm{Ti}, \mathrm{Zr}, \mathrm{Hf}, \mathrm{Mn}, \mathrm{Fe}, \mathrm{Cu}, \mathrm{Zn}, \mathrm{Cd}$. In Hydrogen Storage Materials; Burzo, E., Ed.; Springer: Berlin/Heidelberg, Germany, 2018; pp. 297-299. [CrossRef]

4. $\quad$ Paskevicius, M.; Ley, M.B.; Sheppard, D.A.; Jensen, R.; Buckley, C.E. Eutectic melting in metal borohydrides. Phys. Chem. Chem. Phys. 2013, 15, 19774-19789. [CrossRef]

5. Zhang, Q.; Gao, Z.; Shi, X.; Zhang, C.; Liu, K.; Zhang, J.; Zhou, L.; Ma, C.; Du, Y. Recent advances on rare earths in solid lithium ion conductors. J. Rare Earths 2021, 39, 1-10. [CrossRef] 
6. Ohno, S.; Banik, A.; Dewald, G.F.; Kraft, M.A.; Krauskopf, T.; Minafra, N.; Till, P.; Weiss, M.; Zeier, W.G. Materials design of ionic conductors for solid state batteries. Prog. Energy 2020, 2, 022001. [CrossRef]

7. Wegner, W.; Jaron, T.; Grochala, W. Preparation of a series of lanthanide borohydrides and their thermal decomposition to refractory lanthanide borides. J. Alloys Compd. 2018, 744, 57-63. [CrossRef]

8. Luo, W.; Huang, Z.; Cai, X.; Niu, R.; Nie, R.; Feng, Q.; Wang, F.; Gan, Z. Microstructure and superconducting properties of MgB 2 bulks prepared from $\mathrm{Mg}+\mathrm{B}+\mathrm{Mg}\left(\mathrm{BH}_{4}\right)_{2}$ composites. Supercond. Sci. Technol. 2019, 32, 085006. [CrossRef]

9. Fujii, H.; Ozawa, K. Superconducting properties of PIT-processed $\mathrm{MgB}_{2}$ tapes using $\mathrm{Mg}\left(\mathrm{BH}_{4}\right)_{2}$ precursor. Supercond. Sci. Technol. 2011, 24, 095009. [CrossRef]

10. Andrievski, R.A. Nanostructured titanium, zirconium and hafnium diborides: The synthesis, properties, size effects and stability. Russ. Chem. Rev. 2015, 84, 540-554. [CrossRef]

11. Yang, Y.; Jayaraman, S.; Kim, D.Y.; Girolami, G.S.; Abelson, J.R. CVD growth kinetics of $\mathrm{HfB}_{2}$ thin films from the single-source precursor $\mathrm{Hf}\left(\mathrm{BH}_{4}\right)_{4}$. Chem. Mater. 2006, 18, 5088-5096. [CrossRef]

12. Kang, S.-W.; Park, Y.-J.; Kim, Y.-S.; Shin, Y.-H.; Yun, J.-Y. Real-Time Evaluation of Aluminum Borohydride Trimethylamine for Aluminum Chemical Vapor Deposition. J. Electrochem. Soc. 2009, 156, H333. [CrossRef]

13. Grinderslev, J.B.; Møller, K.T.; Bremholm, M.; Jensen, T.R. Trends in Synthesis, Crystal Structure, and Thermal and Magnetic Properties of Rare-Earth Metal Borohydrides. Inorg. Chem. 2019, 58, 5503-5517. [CrossRef] [PubMed]

14. Ley, M.B.; Boulineau, S.; Janot, R.; Filinchuk, Y.; Jensen, T.R. New Li ion conductors and solid state hydrogen storage materials: $\operatorname{LiM}\left(\mathrm{BH}_{4}\right)_{3} \mathrm{Cl}, \mathrm{M}=\mathrm{La}, \mathrm{Gd}$. J. Phys. Chem. C 2012, 116, 21267-21276. [CrossRef]

15. Lyubov, D.M.; Tolpygin, A.O.; Trifonov, A.A. Rare-earth metal complexes as catalysts for ring-opening polymerization of cyclic esters. Coord. Chem. Rev. 2019, 392, 83-145. [CrossRef]

16. Visseaux, M.; Bonnet, F. Borohydride complexes of rare earths, and their applications in various organic transformations. Coord. Chem. Rev. 2011, 255, 374-420. [CrossRef]

17. Richter, B.; Grinderslev, J.B.; Møller, K.T.; Paskevicius, M.; Jensen, T.R. From Metal Hydrides to Metal Borohydrides. Inorg. Chem. 2018, 57, 10768-10780. [CrossRef]

18. Wylezich, T.; Sontakke, A.D.; Castaing, V.; Suta, M.; Viana, B.; Meijerink, A.; Kunkel, N. One Ion, Many Facets: Efficient, Structurally and Thermally Sensitive Luminescence of $\mathrm{Eu}^{2+}$ in Binary and Ternary Strontium Borohydride Chlorides. Chem. Mater. 2019, 31, 8957-8968. [CrossRef]

19. Wegner, W.; van Leusen, J.; Majewski, J.; Grochala, W.; Kögerler, P. Borohydride as Magnetic Superexchange Pathway in Late Lanthanide Borohydrides. Eur. J. Inorg. Chem. 2019, 2019, 1776-1783. [CrossRef]

20. Schouwink, P.; Didelot, E.; Lee, Y.S.; Mazet, T.; Černý, R. Structural and magnetocaloric properties of novel gadolinium borohydrides. J. Alloys Compd. 2016, 664, 378-384. [CrossRef]

21. Marks, T.J.; Kolb, J.R. Covalent transition metal, lanthanide, and actinide tetrahydroborate complexes. Chem. Rev. 1977, 77, 263-293. [CrossRef]

22. Černý, R.; Schouwink, P. The crystal chemistry of inorganic metal borohydrides and their relation to metal oxides. Acta Crystallogr. Sect. B Struct. Sci. Cryst. Eng. Mater. 2015, 71, 619-640. [CrossRef]

23. Paskevicius, M.; Jepsen, L.H.; Schouwink, P.; Černý, R.; Ravnsbæk, D.B.; Filinchuk, Y.; Dornheim, M.; Besenbacher, F.; Jensen, T.R. Metal borohydrides and derivatives-synthesis, structure and properties. Chem. Soc. Rev. 2017, 46, 1565-1634. [CrossRef] [PubMed]

24. Bannenberg, L.J.; Heere, M.; Benzidi, H.; Montero, J.; Dematteis, E.M.; Suwarno, S.; Jaroń, T.; Winny, M.; Orłowski, P.A.; Wegner, W.; et al. Metal (boro-) hydrides for high energy density storage and relevant emerging technologies. Int. J. Hydrog. Energy 2020, 45, 33687-33730. [CrossRef]

25. Zanella, P.; Crociani, L.; Masciocchi, N.; Giunchi, G. Facile High-Yield Synthesis of Pure, Crystalline $\mathrm{Mg}\left(\mathrm{BH}_{4}\right)_{2}$. Inorg. Chem. 2007, 46, 9039-9041. [CrossRef] [PubMed]

26. Remhof, A.; Yan, Y.; Friedrichs, O.; Kim, J.W.; Mauron, P.; Borgschulte, A.; Wallacher, D.; Buchsteiner, A.; Hoser, A.; Oh, K.H.; et al. Towards room temperature, direct, solvent free synthesis of tetraborohydrides. J. Phys. Conf. Ser. 2012, 340. [CrossRef]

27. Hagemann, H.; Černý, R. Synthetic approaches to inorganic borohydrides. Dalt. Trans. 2010, 39, 6006. [CrossRef] [PubMed]

28. Bauer, R. Notizen: Zur Kenntnis der Magnesiumboranat-Bildung. Z. Naturforsch. B 1962, 17, 277-278. [CrossRef]

29. Jaroń, T.; Orłowski, P.A.; Wegner, W.; Fijałkowski, K.J.; Leszczyński, P.J.; Grochala, W. Hydrogen Storage Materials: RoomTemperature Wet-Chemistry Approach toward Mixed-Metal Borohydrides. Angew. Chemie 2015, 127, 1252-1255. [CrossRef]

30. Nakamori, Y.; Miwa, K.; Ninomiya, A.; Li, H.; Ohba, N.; Towata, S.I.; Züttel, A.; Orimo, S.I. Correlation between thermodynamical stabilities of metal borohydrides and cation electronegativites: First-principles calculations and experiments. Phys. Rev. B-Condens. Matter Mater. Phys. 2006, 74, 1-9. [CrossRef]

31. Payandeh Gharibdoust, S.; Heere, M.; Nervi, C.; Sørby, M.H.; Hauback, B.C.; Jensen, T.R. Synthesis, structure, and polymorphic transitions of praseodymium(III) and neodymium(III) borohydride, $\operatorname{Pr}\left(\mathrm{BH}_{4}\right)_{3}$ and $\mathrm{Nd}\left(\mathrm{BH}_{4}\right)_{3}$. Dalt. Trans. 2018, 47, 8307-8319. [CrossRef]

32. Díaz-Torres, R.; Alvarez, S. Coordinating ability of anions and solvents towards transition metals and lanthanides. Dalt. Trans. 2011, 40, 10742. [CrossRef]

33. Łodziana, Z.; van Setten, M.J. Binding in alkali and alkaline-earth tetrahydroborates: Special position of magnesium tetrahydroborate. Phys. Rev. B 2010, 81, 024117. [CrossRef] 
34. Besora, M.; Lledós, A. Coordination Modes and Hydride Exchange Dynamics in Transition Metal Tetrahydroborate Complexes. In Contemporary Metal Boron Chemistry I; Springer: Berlin/Heidelberg, Germany, 2007. [CrossRef]

35. Callini, E.; Borgschulte, A.; Hugelshofer, C.L.; Ramirez-Cuesta, A.J.; Züttel, A. The Role of Ti in Alanates and Borohydrides: Catalysis and Metathesis. J. Phys. Chem. C 2014, 118, 77-84. [CrossRef]

36. Chua, Y.S.; Chen, P.; Wu, G.; Xiong, Z. Development of amidoboranes for hydrogen storage. Chem. Commun. 2011, $47,5116$. [CrossRef]

37. Xu, Z.; Lin, Z. Transition metal tetrahydroborato complexes: An orbital interaction analysis of their structure and bonding. Coord. Chem. Rev. 1996, 156, 139-162. [CrossRef]

38. Nakamoto, K. Infrared and Raman Spectra of Inorganic and Coordination Compounds. Handbook of Vibrational Spectroscopy. Handb. Vib. Spectrosc. 2006, 1872-1892. [CrossRef]

39. D'Anna, V.; Spyratou, A.; Sharma, M.; Hagemann, H. FT-IR spectra of inorganic borohydrides. Spectrochim. Acta-Part A Mol. Biomol. Spectrosc. 2014, 128, 902-906. [CrossRef] [PubMed]

40. Morris, J.H.; Smith, W.E. Synthesis and characterisation of a tetrahydrofuran derivative of scandium tetrahydroborate. J. Chem. Soc. D Chem. Commun. 1970, 245a. [CrossRef]

41. Hwang, S.J.; Bowman, R.C.; Reiter, J.W.; Rijssenbeek, J.; Soloveichik, G.L.; Zhao, J.C.; Kabbour, H.; Ahn, C.C. NMR confirmation for formation of $\left[\mathrm{B}_{12} \mathrm{H}_{12}\right]^{2-}$ complexes during hydrogen desorption from metal borohydrides. J. Phys. Chem. C 2008, 112, 3164-3169. [CrossRef]

42. Hagemann, H.; Longhini, M.; Kaminski, J.W.; Wesolowski, T.A.; Černý, R.; Penin, N.; Sørby, M.H.; Hauback, B.C.; Severa, G.; Jensen, C.M. $\mathrm{LiSc}\left(\mathrm{BH}_{4}\right)_{4}$ : A novel salt of $\mathrm{Li}$ and discrete $\mathrm{Sc}\left(\mathrm{BH}_{4}\right)_{4}{ }^{-}$Complex anions. J. Phys. Chem. A 2008, 112, 7551-7555. [CrossRef]

43. Černý, R.; Severa, G.; Ravnsbæk, D.B.; Filinchuk, Y.; D'Anna, V.; Hagemann, H.; Haase, D.; Jensen, C.M.; Jensen, T.R. NaSc(BH $)_{4}$ : A novel scandium-based borohydride. J. Phys. Chem. C 2010, 114, 1357-1364. [CrossRef]

44. Kim, C.; Hwang, S.J.; Bowman, R.C.; Reiter, J.W.; Zan, J.A.; Kulleck, J.G.; Kabbour, H.; Majzoub, E.H.; Ozolins, V. LiSc(BH 4$)_{4}$ as a hydrogen storage material: Multinuclear high-resolution solid-state NMR and first-principles density functional theory studies. $J$. Phys. Chem. C 2009, 113, 9956-9968. [CrossRef]

45. Tran, H.D.; Amsler, M.; Botti, S.; Marques, M.A.L.; Goedecker, S. First-principles predicted low-energy structures of $\mathrm{NaSc}\left(\mathrm{BH}_{4}\right)_{4}$ J. Chem. Phys. 2014, 140. [CrossRef]

46. Huang, L.W.; Elkedim, O.; Li, X. First principles investigation of scandium-based borohydride $\left.\mathrm{NaSc}_{(\mathrm{BH}}\right)_{4}$. J. Alloys Compd. 2012, 536, S546-S549. [CrossRef]

47. Kim, K.C. Validation of the reaction thermodynamics associated with $\mathrm{NaSc}\left(\mathrm{BH}_{4}\right)_{4}$ from first-principles calculations: Detecting metastable paths and identifying the minimum free energy path. J. Chem. Phys. 2012, 137, 084111. [CrossRef] [PubMed]

48. Kim, K.C. Crystal structures and thermodynamic investigations of $\mathrm{NaSc}\left(\mathrm{BH}_{4}\right)_{4}$ from first-principles calculations. Int. J. Quantum Chem. 2013, 113, 119-124. [CrossRef]

49. Černý, R.; Ravnsbæk, D.B.; Severa, G.; Filinchuk, Y.; D’Anna, V.; Hagemann, H.; Haase, D.; Skibsted, J.; Jensen, C.M.; Jensen, T.R. Structure and characterization of $\mathrm{KSc}_{(}\left(\mathrm{BH}_{4}\right)_{4}$. J. Phys. Chem. C 2010, 114, 19540-19549. [CrossRef]

50. Starobrat, A.; Jaron, T.; Grochala, W. Two new derivatives of scandium borohydride, $\left.\mathrm{MSc}_{(\mathrm{BH}}\right)_{4}, \mathrm{M}=\mathrm{Rb}, \mathrm{Cs}$, prepared: Via a one-pot solvent-mediated method. Dalt. Trans. 2019, 48, 11829-11837. [CrossRef]

51. Zange, E. Entwicklung eines Mikroverfahrens zur Darstellung von Boranaten der schweren Lanthaniden. Chem. Ber. 1960, 93, 652-657. [CrossRef]

52. Segal, B.G.; Lippard, S.J. Transition metal hydroborate complexes. 10. Crystal and molecular structure of tris(tetrahydroborato)tris(tetrahyd Inorg. Chem. 1978, 17, 844-850. [CrossRef]

53. Sato, T.; Miwa, K.; Nakamori, Y.; Ohoyama, K.; Li, H.; Noritake, T.; Aoki, M. Experimental and computational studies on

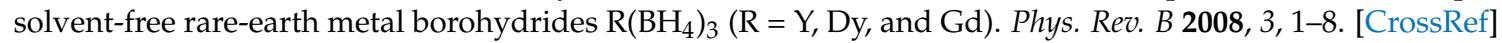

54. Remhof, A.; Borgschulte, A.; Friedrichs, O.; Mauron, P.; Yan, Y.; Züttel, A. Solvent-free synthesis and decomposition of $\left.\mathrm{Y}_{(\mathrm{BH}}\right)_{3}$. Scr. Mater. 2012, 66, 280-283. [CrossRef]

55. Park, K.; Lee, H.-S.; Remhof, A.; Lee, Y.-S.; Yan, Y.; Kim, M.-Y.; Kim, S.J.; Züttel, A.; Cho, Y.W. Thermal properties of Y(BH $\left.{ }_{4}\right)_{3}$ synthesized via two different methods. Int. J. Hydrog. Energy 2013, 38, 9263-9270. [CrossRef]

56. Jaron, T.; Grochala, W. Y $\left(\mathrm{BH}_{4}\right)_{3}$ —an old-new ternary hydrogen store akalearning from a multitude of failures. Dalt. Trans. 2010, 39, 160-166. [CrossRef]

57. Ravnsbæk, D.B.; Filinchuk, Y.; Cern, R.; Jakobsen, H.J.; Jensen, T.R.; Esrf, S.B. Thermal Polymorphism and Decomposition of $\mathrm{Y}\left(\mathrm{BH}_{4}\right)_{3}$. Inorg. Chem. 2010, 3801-3809. [CrossRef]

58. Frommen, C.; Aliouane, N.; Deledda, S.; Fonneløp, J.E.; Grove, H.; Lieutenant, K.; Llamas-Jansa, I.; Sartori, S.; Sørby, M.H.; Hauback, B.C. Crystal structure, polymorphism, and thermal properties of yttrium borohydride Y $\left(\mathrm{BH}_{4}\right)_{3}$. J. Alloys Compd. 2010, 496, 710-716. [CrossRef]

59. Yan, Y.; Remhof, A.; Rentsch, D.; Lee, Y.-S.; Whan Cho, Y.; Züttel, A. Is $\mathrm{Y}_{2}\left(\mathrm{~B}_{12} \mathrm{H}_{12}\right)_{3}$ the main intermediate in the decomposition process of $\mathrm{Y}\left(\mathrm{BH}_{4}\right)_{3}$ ? Chem. Commun. 2013, 49, 5234. [CrossRef]

60. Yan, Y.; Li, H.W.; Sato, T.; Umeda, N.; Miwa, K.; Towata, S.I.; Orimo, S. Dehydriding and rehydriding properties of yttrium borohydride $\mathrm{Y}\left(\mathrm{BH}_{4}\right)_{3}$ prepared by liquid-phase synthesis. Int. J. Hydrog. Energy 2009, 34, 5732-5736. [CrossRef] 
61. Lee, Y.S.; Shim, J.H.; Cho, Y.W. Polymorphism and thermodynamics of $\mathrm{Y}\left(\mathrm{BH}_{4}\right)_{3}$ from first principles. J. Phys. Chem. C 2010, 114, 12833-12837. [CrossRef]

62. Roedern, E.; Lee, Y.-S.; Ley, M.B.; Park, K.; Cho, Y.W.; Skibsted, J.; Jensen, T.R. Solid state synthesis, structural characterization and ionic conductivity of bimetallic alkali-metal yttrium borohydrides $\mathrm{MY}\left(\mathrm{BH}_{4}\right)_{4}(\mathrm{M}=\mathrm{Li}$ and Na). J. Mater. Chem. A 2016, 4, 8793-8802. [CrossRef]

63. Jaroń, T.; Wegner, W.; Fijałkowski, K.J.; Leszczyński, P.J.; Grochala, W. Facile Formation of Thermodynamically Unstable Novel Borohydride Materials by a Wet Chemistry Route. Chem. A Eur. J. 2015, 21, 5689-5692. [CrossRef]

64. Dai, J.; Chen, Y.; Xie, R.; Hu, Z.; Song, Y. Influence of alloying elements on the stability and dehydrogenation properties on $\mathrm{Y}\left(\mathrm{BH}_{4}\right)_{3}$ by first principles calculations. Int. J. Hydrog. Energy 2016, 41, 1662-1671. [CrossRef]

65. Jaroń, T.; Grochala, W. Probing Lewis acidity of $\mathrm{Y}\left(\mathrm{BH}_{4}\right)_{3}$ via its reactions with $\mathrm{MBH}_{4}(\mathrm{M}=\mathrm{Li}, \mathrm{Na}, \mathrm{K}, \mathrm{NMe})_{4}$. Dalt. Trans. 2011, 40, 12808-12817. [CrossRef]

66. Ravnsbæk, D.B.; Ley, M.B.; Lee, Y.S.; Hagemann, H.; D’Anna, V.; Cho, Y.W.; Filinchuk, Y.; Jensen, T.R. A mixed-cation mixed-anion borohydride $\mathrm{NaY}\left(\mathrm{BH}_{4}\right)_{2} \mathrm{Cl}_{2}$. Int. J. Hydrog. Energy 2012, 37, 8428-8438. [CrossRef]

67. Jaron, T.; Wegner, W.; Grochala, W. M[Y $\left.\left(\mathrm{BH}_{4}\right)_{4}\right]$ and $\mathrm{M}_{2} \mathrm{Li}\left[\mathrm{Y}\left(\mathrm{BH}_{4}\right)_{6-\mathrm{x}} \mathrm{Cl}_{\mathrm{x}}\right](\mathrm{M}=\mathrm{Rb}, \mathrm{Cs})$ : New borohydride derivatives of yttrium and their hydrogen storage properties. Dalt. Trans. 2013, 42, 6886. [CrossRef] [PubMed]

68. Sadikin, Y.; Stare, K.; Schouwink, P.; Brix Ley, M.; Jensen, T.R.; Meden, A.; Černý, R. Alkali metal-Yttrium borohydrides: The link between coordination of small and large rare-earth. J. Solid State Chem. 2015, 225, 231-239. [CrossRef]

69. Schouwink, P.; Ley, M.B.; Tissot, A.; Hagemann, H.; Jensen, T.R.; Smrčok, L.; Černý, R. Structure and properties of complex hydride perovskite materials. Nat. Commun. 2014, 5, 1-10. [CrossRef]

70. Łodziana, Z. Multivalent metal tetrahydroborides of Al, Sc, Y, Ti, and Zr. Phys. Rev. B 2010, 81, 144108. [CrossRef]

71. Dain, C.J.; Downs, A.J.; Goode, M.J.; Evans, D.G.; Nicholls, K.T.; Rankin, D.W.H.; Robertson, H.E. Molecular structure of gaseous titanium tris(tetrahydroborate), $\mathrm{Ti}\left(\mathrm{BH}_{4}\right)_{3}$ : Experimental determination by electron diffraction and molecular orbital analysis of some $\mathrm{Ti}\left(\mathrm{BH}_{4}\right)_{3}$ derivatives. J. Chem. Soc. Dalt. Trans. 1991, 967. [CrossRef]

72. Hoekstra, H.R.; Katz, J.J. The Preparation and Properties of the Group IV-B Metal Borohydrides. J. Am. Chem. Soc. 1949, 71, 2488-2492. [CrossRef]

73. Franz, K.; Fusstetter, H.; Nöth, H. Metallboranate und Boranatometallate. IX [1]; Äther-Addukte von Tris(boranato)-titan(III) und dimere Alkoxy-bis(boranato)-titan(III)-Verbindungen. Z. Anorg. und Allg. Chemie 1976, 427, 97-113. [CrossRef]

74. Jensen, J.A.; Wilson, S.R.; Girolami, G.S. Titanium(III) tetrahydroborates. Preparation and crystal structure of Ti(BH $)_{3}\left(\mathrm{PMe}_{3}\right)_{2}$ containing an unusual Ti.cntdot..cntdot..cntdot.H.cntdot..cntdot..cntdot.B agostic interaction. J. Am. Chem. Soc. 1988, 110, 4977-4982. [CrossRef]

75. Fang, Z.Z.; Ma, L.P.; Kang, X.D.; Wang, P.J.; Wang, P.; Cheng, H.M. In situ formation and rapid decomposition of Ti(BH $)_{3}$ by mechanical milling $\mathrm{LiBH}_{4}$ with $\mathrm{TiF}_{3}$. Appl. Phys. Lett. 2009, 94, 1-4. [CrossRef]

76. Callini, E.; Szilágyi, P.Á.; Paskevicius, M.; Stadie, N.P.; Réhault, J.; Buckley, C.E.; Borgschulte, A.; Züttel, A. Stabilization of volatile $\mathrm{Ti}\left(\mathrm{BH}_{4}\right)_{3}$ by nano-confinement in a metal-organic framework. Chem. Sci. 2016, 7, 666-672. [CrossRef]

77. Jarid, A.; Lledos, A.; Jean, Y.; Volatron, F. Ab initio study of the coordination modes of tetrahydroborato ligands: Structure of the tris(tetrahydroborato)titanium. Inorg. Chem. 1993, 32, 4695-4699. [CrossRef]

78. Reid, W.E.; Bish, J.M.; Brenner, A. Electrodeposition of Metals from Organic Solutions. J. Electrochem. Soc. 1957, 104, 21-29. [CrossRef]

79. Gennari, F.C.; Fernández Albanesi, L.; Rios, I.J. Synthesis and thermal stability of $\mathrm{Zr}\left(\mathrm{BH}_{4}\right)_{4}$ and $\mathrm{Zr}\left(\mathrm{BD}_{4}\right)_{4}$ produced by mechanochemical processing. Inorg. Chim. Acta 2009, 362, 3731-3737. [CrossRef]

80. James, B.D.; Smith, B.E. Convenient, High-Yield Syntheses of Bis(tetrahydroborato)bis(cyclopentadienyl)zirconium(IV) and Tetrakis(tetrahydroborato)zirconium(IV). Synth. React. Inorg. Met. Chem. 1974, 4, 461-465. [CrossRef]

81. Haaland, A.; Shorokhov, D.J.; Tutukin, A.V.; Volden, H.V.; Swang, O.; McGrady, G.S.; Kaltsoyannis, N.; Downs, A.J.; Tang, C.Y.; Turner, J.F.C. Molecular structures of two metal tetrakis(tetrahydroborates), $\mathrm{Zr}\left(\mathrm{BH}_{4}\right)_{4}$ and $\mathrm{U}\left(\mathrm{BH}_{4}\right)_{4}$ : Equilibrium conformations and barriers to internal rotation of the triply bridging $\mathrm{BH}_{4}$ groups. Inorg. Chem. 2002, 41, 6646-6655. [CrossRef] [PubMed]

82. Volkov, V.V.; Myakishev, K.G. Mechanochemical reactions in the chemistry of boranes. Inorg. Chim. Acta 1999, $289,51-57$. [CrossRef]

83. Rude, L.H.; Corno, M.; Ugliengo, P.; Baricco, M.; Lee, Y.-S.; Cho, Y.W.; Besenbacher, F.; Overgaard, J.; Jensen, T.R. Synthesis and Structural Investigation of $\mathrm{Zr}\left(\mathrm{BH}_{4}\right)_{4}$. J. Phys. Chem. C 2012, 116, 20239-20245. [CrossRef]

84. Huang, J.; Tan, Y.; Su, J.; Gu, Q.; Černý, R.; Ouyang, L.; Sun, D.; Yu, X.; Zhu, M. Synthesis, structure and dehydrogenation of zirconium borohydride octaammoniate. Chem. Commun. 2015, 51, 2794-2797. [CrossRef] [PubMed]

85. Wu, D.F.; Ouyang, L.Z.; Huang, J.M.; Liu, J.W.; Wang, H.; Shao, H.; Zhu, M. Synthesis and hydrogen storage property tuning of $\mathrm{Zr}\left(\mathrm{BH}_{4}\right)_{4} \cdot 8 \mathrm{NH}_{3}$ via physical vapour deposition and composite formation. Int. J. Hydrog. Energy 2018, 43, 19182-19188. [CrossRef]

86. Igoshkin, A.M.; Golovnev, I.F.; Krisyuk, V.V.; Igumenov, I.K.; Mechanics, A.; Branch, S.; Branch, S. Structure of Zirconium Tetrahydroborate $\mathrm{Zr}\left(\mathrm{BH}_{4}\right)_{4}$ : A Molecular Dynamics Study. J. Struct. Chem. 2016, 57, 1068-1073. [CrossRef]

87. Green, J.C.; De Simone, M.; Coreno, M.; Jones, A.; Pritchard, H.M.I.; McGrady, G.S. Electronic structure of $\mathrm{M}\left(\mathrm{BH}_{4}\right)_{4}, \mathrm{M}^{2} \mathrm{Zr}$, $\mathrm{Hf}$, and $\mathrm{U}$, by variable photon-energy photoelectron spectroscopy and density functional calculations. Inorg. Chem. 2005, 44, 7781-7793. [CrossRef] 
88. Ehemann, M.; Nöth, H. Metallboranate und Boranatometallate. IV. Boranatokomplexe $\mathrm{M}\left(\mathrm{BH}_{4}\right)_{4+\mathrm{n}}{ }^{\mathrm{n}-}$ des Zirkoniums, Hafniums und Thoriums. Z. Anorg. und Allg. Chemie 1971, 386, 87-101. [CrossRef]

89. Jensen, C.M.; Severa, G.; Zhang, S.; Culnane, L.; Langley, W.; Ayabe, R.; Humphries, T.; Setthanan, U.; McGrady, G.S. IV.A.1j Fundamental Studies of Advanced High-Capacity, Reversible Metal Hydrides. Available online: https:/ /www.hydrogen.energy. gov/pdfs/progress08/iv_a_1j_jensen.pdf (accessed on 12 May 2021).

90. Roy, D.K.; Mondal, B.; De, A.; Panda, S.; Ghosh, S. Novel Neutral Zirconaborane $\left[\left(\mathrm{Cp}_{2} \mathrm{Zr}_{2} \mathrm{~B}_{5} \mathrm{H}_{11}\right]\right.$ : An arachno - $\mathrm{B}_{3} \mathrm{H}_{9}$ Analogue $\left(\mathrm{Cp}=\eta^{5}-\mathrm{C}_{5} \mathrm{H}_{5}\right)$. Organometallics 2015, 34, 908-912. [CrossRef]

91. Tamami, B.; Goudarzian, N. Polymer supported ziroconium borohydride: A stable, efficient and regenerable reducing agent. J. Chem. Soc. Chem. Commun. 1994, 1079. [CrossRef]

92. Borisenko, K.B.; Downs, A.J.; Robertson, H.E.; Rankin, D.W.H.; Tang, C.Y. Molecular structure of $\mathrm{Hf}_{(}\left(\mathrm{BH}_{4}\right)_{4}$ investigated by quantum mechanical calculations and gas-phase electron diffraction. Dalt. Trans. 2004, 967-970. [CrossRef]

93. Broach, R.W.; Chuang, I.S.; Marks, T.J.; Williams, J.M. Metrical characterization of tridentate tetrahydroborate ligation to a transition-metal ion. Structure and bonding in $\mathrm{Hf}\left(\mathrm{BH}_{4}\right)_{4}$ by single-crystal neutron diffraction. Inorg. Chem. 1983, 22, 1081-1084. [CrossRef]

94. Jensen, J.A.; Gozum, J.E.; Pollina, D.M.; Girolami, G.S. Titanium, zirconium, and hafnium tetrahydroborates as "tailored" CVD precursors for metal diboride thin films. J. Am. Chem. Soc. 1988, 110, 1643-1644. [CrossRef]

95. Wayda, A.L.; Schneemeyer, L.F.; Opila, R.L. Low-temperature deposition of zirconium and hafnium boride films by thermal decomposition of the metal borohydrides $\left.\left(\mathrm{M}^{2} \mathrm{BH}_{4}\right]_{4}\right)$. Appl. Phys. Lett. 1988, 53, 361-363. [CrossRef]

96. Yang, C.H.; Tsai, W.T.; Chang, J.K. Hydrogen desorption behavior of vanadium borohydride synthesized by modified mechanochemical process. Int. J. Hydrog. Energy 2011, 36, 4993-4999. [CrossRef]

97. Korablov, D.; Ravnsbæk, D.B.; Ban, V.; Filinchuk, Y.; Besenbacher, F.; Jensen, T.R. Investigation of $\mathrm{MBH}_{4}-\mathrm{VCl}_{2}, \mathrm{M}=\mathrm{Li}_{1} \mathrm{Na}$ or $\mathrm{K}$. Int. J. Hydrog. Energy 2013, 38, 8376-8383. [CrossRef]

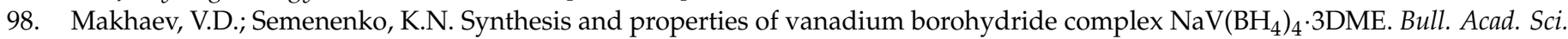
USSR Div. Chem. Sci. 1978, 27, 2520-2521. [CrossRef]

99. Jensen, J.A.; Girolami, G.S. Vanadium(III) tetrahydroborates. Preparation, reaction chemistry, and crystal structures of $\mathrm{V}\left(\mathrm{BH}_{4}\right)_{3}\left(\mathrm{PMe}_{3}\right)_{2}$ and the oxo dimer $\left[\mathrm{V}\left(\mathrm{BH}_{4}\right)_{2}(\mathrm{PMe} 3)_{2}\right]_{2} \mathrm{O}$. Inorg. Chem. 1989, 28, 2114-2119. [CrossRef]

100. Jensen, J.A.; Girolami, G.S. Vanadium tetrahydroborates: Preparation and characterization of $\mathrm{V}\left(\mathbf{(}^{2}-\mathrm{BH}_{4}\right)_{3}\left(\mathrm{PMe}_{3}\right)_{2}$ and the unusual unidentate $\mathrm{BH}_{4}-$ complex $\mathrm{V}\left(\mathbf{\square}^{1}-\mathrm{BH}_{4}\right)_{2}(\mathrm{dmpe})_{2}$. J. Am. Chem. Soc. 1988, 110, 4450-4451. [CrossRef]

101. Hummelshøj, J.S.; Landis, D.D.; Voss, J.; Jiang, T.; Tekin, A.; Bork, N.; Duak, M.; Mortensen, J.J.; Adamska, L.; Andersin, J.; et al Density functional theory based screening of ternary alkali-transition metal borohydrides: A computational material design project. J. Chem. Phys. 2009, 131. [CrossRef] [PubMed]

102. Charkin, O.P. Theoretical study of tetrahydroborates and alanates $\mathrm{L}\left(\mathrm{MH}_{4}\right)_{4}, \mathrm{HL}\left(\mathrm{MH}_{4}\right)_{3}, \mathrm{H}_{2} \mathrm{~L}\left(\mathrm{MH}_{4}\right)_{2}$, and $\mathrm{H}_{3} \mathrm{~L}\left(\mathrm{MH} \mathrm{H}_{4}\right)(\mathrm{L}=\mathrm{Al}, \mathrm{Sc}$, $\mathrm{Ti}, \mathrm{V}, \mathrm{Cr} ; \mathrm{M}=\mathrm{B}, \mathrm{Al})$. Russ. J. Inorg. Chem. 2009, 54, 951-960. [CrossRef]

103. Nöth, H. Anorganische Reaktionen der Alkaliboranate. Angew. Chemie 1961, 73, 371-383. [CrossRef]

104. Suárez-Alcántara, K.; Tena-Garcia, J.R.; Guerrero-Ortiz, R. Alanates, a comprehensive review. Materials 2019, 12, 2724. [CrossRef]

105. Seitz, M.A.X. Preparation and Characterization of Chromium(II) Tetrahydroborate- Tetrahydrofuran (1/2). J. Chem. Soc. Chem. Commun. 1976, 547, 1976.

106. Dionne, M.; Hao, S.; Gambarotta, S. Preparation and characterization of a new series of Cr(II) hydroborates. Can. J. Chem. 1995, 73, 1126-1134. [CrossRef]

107. Nakamori, Y.; Li, H.W.; Matsuo, M.; Miwa, K.; Towata, S.; Orimo, S. Development of metal borohydrides for hydrogen storage. J. Phys. Chem. Solids 2008, 69, 2292-2296. [CrossRef]

108. Schouwink, P.; D’Anna, V.; Ley, M.B.; Lawson Daku, L.M.; Richter, B.; Jensen, T.R.; Hagemann, H.; Černý, R. Bimetallic borohydrides in the system $\mathrm{M}\left(\mathrm{BH}_{4}\right)_{2}-\mathrm{KBH}_{4}(\mathrm{M}=\mathrm{Mg}$, Mn): On the structural diversity. J. Phys. Chem. C 2012, 116, 10829-10840. [CrossRef]

109. Richter, B.; Ravnsbæk, D.B.; Tumanov, N.; Filinchuk, Y.; Jensen, T.R. Manganese borohydride; Synthesis and characterization. Dalt. Trans. 2015, 44, 3988-3996. [CrossRef] [PubMed]

110. Tumanov, N.A.; Safin, D.A.; Richter, B.; Łodziana, Z.; Jensen, T.R.; Garcia, Y.; Filinchuk, Y. Challenges in the synthetic routes to $\mathrm{Mn}\left(\mathrm{BH}_{4}\right)_{2}$ : Insight into intermediate compounds. Dalt. Trans. 2015, 44, 6571-6580. [CrossRef]

111. Tumanov, N.A.; Roedern, E.; Łodziana, Z.; Nielsen, D.B.; Jensen, T.R.; Talyzin, A.V.; Černý, R.; Chernyshov, D.; Dmitriev, V.; Palasyuk, T.; et al. High-Pressure Study of $\mathrm{Mn}\left(\mathrm{BH}_{4}\right)_{2}$ Reveals a Stable Polymorph with High Hydrogen Density. Chem. Mater. 2016, 28, 274-283. [CrossRef]

112. Liu, R.; Reed, D.; Book, D. Decomposition behaviour of $\mathrm{Mn}\left(\mathrm{BH}_{4}\right)_{2}$ formed by ball-milling $\mathrm{LiBH}_{4}$ and $\mathrm{MnCl}_{2}$. J. Alloys Compd. 2012, 515, 32-38. [CrossRef]

113. Makhaev, V.D.; Borisov, A.P.; Gnilomedova, T.P.; Lobkovskii, É.B.; Chekhlov, A.N. Production of manganese borohydride complexes of manganese solvated with THF, and the structure of $\mathrm{Mn}\left(\mathrm{BH}_{4}\right)_{2}(\mathrm{THF})_{3}$. Bull. Acad. Sci. USSR Div. Chem. Sci. 1987, 36, 1582-1586. [CrossRef]

114. Severa, G.; Hagemann, H.; Longhini, M.; Kaminski, J.W.; Wesolowski, T.A.; Jensen, C.M. Thermal desorption, vibrational spectroscopic, and DFT computational studies of the complex manganese borohydrides $\mathrm{Mn}\left(\mathrm{BH}_{4}\right)_{2}$ and $\left[\mathrm{Mn}\left(\mathrm{BH}_{4}\right)_{4}\right]^{2-}$. J. Phys. Chem. C 2010, 114, 15516-15521. [CrossRef] 
115. Černý, R.; Penin, N.; Hagemann, H.; Filinchuk, Y. The first crystallographic and spectroscopic characterization of a 3d-Metal borohydride: $\mathrm{Mn}\left(\mathrm{BH}_{4}\right)_{2}$. J. Phys. Chem. C 2009, 113, 9003-9007. [CrossRef]

116. Bidabadi, A.S.; Korinek, A.; Botton, G.A.; Varin, R.A. High resolution transmission electron microscopy (TEM), energy-dispersive X-ray spectroscopy (EDS) and X-ray diffraction studies of nanocrystalline manganese borohydride $\left(\mathrm{Mn}\left(\mathrm{BH}_{4}\right)_{2}\right)$ after mechanochemical synthesis and thermal dehydrogenation. Acta Mater. 2015, 100, 392-400. [CrossRef]

117. Choudhury, P.; Bhethanabotla, V.R.; Stefanakos, E. Manganese borohydride as a hydrogen-storage candidate: First-principles crystal structure and thermodynamic properties. J. Phys. Chem. C 2009, 113, 13416-13424. [CrossRef]

118. Varin, R.A.; Bidabadi, A.S. The effect of milling energy input during mechano-chemical activation synthesis (MCAS) of the nanocrystalline manganese borohydride $\left(\mathrm{Mn}_{(}\left(\mathrm{BH}_{4}\right)_{2}\right)$ on its thermal dehydrogenation properties. Int. J. Hydrog. Energy 2014, 39, 11620-11632. [CrossRef]

119. Zavorotynska, O.; El-Kharbachi, A.; Deledda, S.; Hauback, B.C. Recent progress in magnesium borohydride $\mathrm{Mg}\left(\mathrm{BH}_{4}\right)_{2}: \mathrm{Funda}$ mentals and applications for energy storage. Int. J. Hydrog. Energy 2016, 41, 14387-14403. [CrossRef]

120. Roedern, E.; Jensen, T.R. Thermal decomposition of $\mathrm{Mn}\left(\mathrm{BH}_{4}\right)_{2}-\mathrm{M}\left(\mathrm{BH}_{4}\right)_{\mathrm{x}}$ and $\mathrm{Mn}\left(\mathrm{BH}_{4}\right)_{2}-\mathrm{MH}_{\mathrm{x}}$ composites with $\mathrm{M}=\mathrm{Li}, \mathrm{Na}, \mathrm{Mg}$, and Ca. J. Phys. Chem. C 2014, 118, 23567-23574. [CrossRef]

121. Pankin, I.A.; Guda, A.A.; Tumanov, N.A.; Filinchuk, Y.; Lomachenko, K.A.; Bugaev, A.L.; Guda, S.A.; Shapovalov, V.V.; Lamberti,

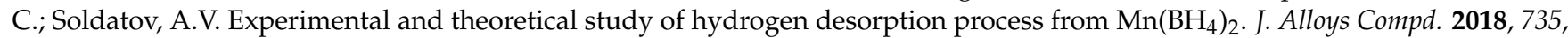
277-284. [CrossRef]

122. Varin, R.A.; Zbroniec, L.; Polanski, M.; Filinchuk, Y.; Černý, R. Mechano-chemical synthesis of manganese borohydride $\left(\mathrm{Mn}\left(\mathrm{BH}_{4}\right)_{2}\right)$ and inverse cubic spinel $\left(\mathrm{Li}_{2} \mathrm{MnCl}_{4}\right)$ in the $\left(\mathrm{nLiBH}_{4}+\mathrm{MnCl}_{2}\right)(\mathrm{n}=1,2,3,5,9$ and 23) mixtures and their dehydrogenation behavior. Int. J. Hydrog. Energy 2012, 37, 16056-16069. [CrossRef]

123. Varin, R.A.; Bidabadi, A.S.; Polanski, M.; Biglari, M.; Stobinski, L. The effects of filamentary Ni, graphene and lithium amide $\left(\mathrm{LiNH}_{2}\right)$ additives on the dehydrogenation behavior of mechano-chemically synthesized crystalline manganese borohydride $\left(\mathrm{Mn}\left(\mathrm{BH}_{4}\right)_{2}\right)$ and its solvent filtration/extraction. Mater. Res. Bull. 2018, 100, 394-406. [CrossRef]

124. Guda, A.A.; Pankin, I.A.; Bugaev, A.L.; Lomachenko, K.A.; Guda, S.A.; Dmitriev, V.P.; Soldatov, A.V. X-ray absorption spectroscopy determination of the products of manganese borohydride decomposition upon heating. Bull. Russ. Acad. Sci. Phys. 2015, 79, 139-143. [CrossRef]

125. Choudhury, P.; Srinivasan, S.S.; Bhethanabotla, V.R.; Goswami, Y.; McGrath, K.; Stefanakos, E.K. Nano-Ni doped Li-Mn-B-H system as a new hydrogen storage candidate. Int. J. Hydrog. Energy 2009, 34, 6325-6334. [CrossRef]

126. Fang, F.; Li, Y.T.; Song, Y.; Zha, J.; Zhao, B.; Sun, D.L. LiMn $\left(\mathrm{BH}_{4}\right)_{3} / 2 \mathrm{LiCl}$ Composite Synthesized by Reactive Ball-Milling and Its Dehydrogenation Properties. Acta Phys. Chim. Sin. 2011, 27, 1537-1542. [CrossRef]

127. Varin, R.A.; Zbroniec, L. The effects of ball milling and nanometric nickel additive on the hydrogen desorption from lithium borohydride and manganese chloride $\left(3 \mathrm{LiBH}_{4}+\mathrm{MnCl}_{2}\right)$ mixture. Int. J. Hydrog. Energy 2010, 35, 3588-3597. [CrossRef]

128. Černý, R.; Penin, N.; D’Anna, V.; Hagemann, H.; Durand, E.; Růžička, J. $\mathrm{Mg}_{\mathrm{x}} \mathrm{Mn}_{(1-\mathrm{x})}\left(\mathrm{BH}_{4}\right)_{2}(\mathrm{x}=0-0.8)$, a cation solid solution in a bimetallic borohydride. Acta Mater. 2011, 59, 5171-5180. [CrossRef]

129. Černý, R.; Schouwink, P.; Sadikin, Y.; Stare, K.; Smrčok, L.; Richter, B.; Jensen, T.R. Trimetallic borohydride $\operatorname{Li}_{3} \mathrm{MZn}_{5}\left(\mathrm{BH}_{4}\right)_{15}(\mathrm{M}=$ $\mathrm{Mg}, \mathrm{Mn}$ ) containing two weakly interconnected frameworks. Inorg. Chem. 2013, 52, 9941-9947. [CrossRef]

130. Schaeffer, G.W.; Roscoe, J.S.; Stewart, A.C. The Reduction of Iron(III) Chloride with Lithium Aluminohydride and Lithium Borohydride: Iron(II) Borohydride. J. Am. Soc. 1956, 78, 729-733. [CrossRef]

131. Varin, R.A.; Bidabadi, A.S. Rapid, ambient temperature hydrogen generation from the solid state Li-B-Fe-H system by mechanochemical activation synthesis. J. Power Sources 2015, 284, 554-565. [CrossRef]

132. Varin, R.A.; Shirani Bidabadi, A. Nanostructured, complex hydride systems for hydrogen generation. AIMS Energy 2015, 3 , 121-143. [CrossRef]

133. Stewart, A.C.; Schaeffer, G.W. The reaction of cobalt(II) bromide with lithium borohydride and lithium aluminohydride. J. Inorg. Nucl. Chem. 1956, 3, 194-197. [CrossRef]

134. Raje, S.; Angamuthu, R. Solvent-free synthesis and reactivity of nickel(II) borohydride and nickel(II) hydride. Green Chem. 2019, 21, 2752-2758. [CrossRef]

135. Wiberg, E. Zur kenntnis eines kupfer-bor-wasserstoffs $\mathrm{CuBH}_{4}$. Z. Naturforsch. B 1952, 7b, 582. [CrossRef]

136. Klingen, T.J. The Reaction of Copper(II) Chloride with Lithium Borohydride. Inorg. Chem. 1964, 3, 1058-1059. [CrossRef]

137. Wiberg, E.; Henle, W. Notizen: Zur Kenntnis eines Silber-bor-wasserstoffs AgBH 4 . Z. Naturforsch. B 1952, 7, 575-576. [CrossRef]

138. Wiberg, E. Neuere Ergebnisse der praparativen Hydrid-Forschung. Angew. Chemie 1953, 65, 16-33. [CrossRef]

139. Musaev, D.G.; Morokuma, K. Does the Tetrahydroborate Species $\mathrm{AuBH}_{4}$ Exist? Ab Initio MO Study of the Structure and Stability of $\mathrm{CuBH}_{4}, \mathrm{AgBH}_{4}$, and $\mathrm{AuBH}_{4}$. Organometallics 1995, 14, 3327-3334. [CrossRef]

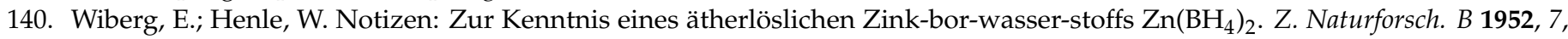
579-580. [CrossRef]

141. Nöth, H.; Wiberg, E.; Winter, L.P. Boranate und Boranato-metallate. I. Zur Kenntnis von Solvaten des Zinkboranats. Z. Anorg. Allg. Chemie 1969, 370, 209-223. [CrossRef]

142. Narasimhan, S.; Balakumar, R. Synthetic applications of zinc borohydride. Aldrichimica Acta 1998, 31, $19-26$.

143. Friedrichs, O.; Borgschulte, A.; Kato, S.; Buchter, F.; Gremaud, R.; Remhof, A.; Züttel, A. Low-Temperature Synthesis of LiBH 4 by Gas-Solid Reaction. Chem. A Eur. J. 2009, 15, 5531-5534. [CrossRef] 
144. Choudhury, P.; Bhethanabotla, V.R.; Stefanakos, E. Identification of a stable phase for the high-capacity hydrogen-storage material $\mathrm{Zn}\left(\mathrm{BH}_{4}\right)_{2}$ from density functional theory and lattice dynamics. Phys. Rev. B Condens. Matter Mater. Phys. 2008, 77. [CrossRef]

145. Huan, T.D.; Amsler, M.; Tuoc, V.N.; Willand, A.; Goedecker, S. Low-energy structures of zinc borohydride $\mathrm{Zn}_{(}\left(\mathrm{BH}_{4}\right)_{2}$. Phys. Rev. B Condens. Matter Mater. Phys. 2012, 86, 1-8. [CrossRef]

146. Aidhy, D.S.; Wolverton, C. First-principles prediction of phase stability and crystal structures in Li-Zn and Na-Zn mixed-metal borohydrides. Phys. Rev. B Condens. Matter Mater. Phys. 2011, 83, 1-8. [CrossRef]

147. Ravnsbæk, D.; Filinchuk, Y.; Cerenius, Y.; Jakobsen, H.J.; Besenbacher, F.; Skibsted, J.; Jensen, T.R. A series of mixed-metal borohydrides. Angew. Chemie Int. Ed. 2009, 48, 6659-6663. [CrossRef] [PubMed]

148. Jeon, E.; Cho, Y.W. Mechanochemical synthesis and thermal decomposition of zinc borohydride. J. Alloys Compd. 2006, 422, 273-275. [CrossRef]

149. Srinivasan, S.; Escobar, D.; Jurczyk, M.; Goswami, Y.; Stefanakos, E. Nanocatalyst doping of $\mathrm{Zn}_{(}\left(\mathrm{BH}_{4}\right)_{2}$ for on-board hydrogen storage. J. Alloys Compd. 2008, 462, 294-302. [CrossRef]

150. Srinivasan, S.; Escobar, D.; Goswami, Y.; Stefanakos, E. Effects of catalysts doping on the thermal decomposition behavior of $\mathrm{Zn}\left(\mathrm{BH}_{4}\right)_{2}$. Int. J. Hydrog. Energy 2008, 33, 2268-2272. [CrossRef]

151. Yang, B.; Li, S.; Wang, H.; Xiang, J.; Yang, Q. Effect of MWCNTs additive on desorption properties of $\mathrm{Zn}_{(}\left(\mathrm{BH}_{4}\right)_{2}$ composite prepared by mechanical alloying. J. Mater. Sci. Technol. 2013, 29, 715-719. [CrossRef]

152. Nakagawa, T.; Ichikawa, T.; Kojima, Y.; Fujii, H. Gas emission properties of the $\mathrm{MgH}_{\mathrm{x}}-\mathrm{Zn}\left(\mathrm{BH}_{4}\right)_{2}$ systems. Mater. Trans. 2007, 48, 556-559. [CrossRef]

153. Park, H.R.; Kwak, Y.J.; Song, M.Y. Role of the Added Ni in Hydrogen-Storage Reactions of $\mathrm{MgH}_{2}-\mathrm{Zn}\left(\mathrm{BH}_{4}\right)_{2}-\mathrm{Tm}(\mathrm{Ni}$, Ti, or Fe) Alloys. Mater. Sci. 2018, 24. [CrossRef]

154. Song, M.Y.; Kwak, Y.J. Comparison of the Hydrogen Release Properties of $\mathrm{Zn}\left(\mathrm{BH}_{4}\right)_{2}-\mathrm{Added}_{\mathrm{MgH}} \mathrm{Alloy}$ and $\mathrm{Zn}\left(\mathrm{BH}_{4}\right)_{2}$ and Ni-Added $\mathrm{MgH}_{2}$ Alloy. Korean J. Met. Mater. 2018, 56. [CrossRef]

155. Černý, R.; Chul Kim, K.; Penin, N.; D'Anna, V.; Hagemann, H.; Sholl, D.S. AZn ${ }_{2}\left(B_{4}\right)_{5}(A=L i, N a)$ and NaZn $\left(B H_{4}\right)_{3}$ : Structural Studies. J. Phys. Chem. C 2010, 114, 19127-19133. [CrossRef]

156. Ravnsbæk, D.B.; Frommen, C.; Reed, D.; Filinchuk, Y.; Sørby, M.; Hauback, B.C.; Jakobsen, H.J.; Book, D.; Besenbacher, F.; Skibsted, J.; et al. Structural studies of lithium zinc borohydride by neutron powder diffraction, Raman and NMR spectroscopy. J. Alloys Compd. 2011, 509, 698-704. [CrossRef]

157. Ravnsbæk, D.B.; Filinchuk, Y.; Černý, R.; Jensen, T.R. Powder diffraction methods for studies of borohydride-based energy storage materials. Z. Krist. 2010, 225, 557-569. [CrossRef]

158. Wang, Y.; Zhang, Y.; Wolverton, C. First-principles studies of phase stability and crystal structures in Li-Zn mixed-metal borohydrides. Phys. Rev. B Condens. Matter Mater. Phys. 2013, 88, 1-10. [CrossRef]

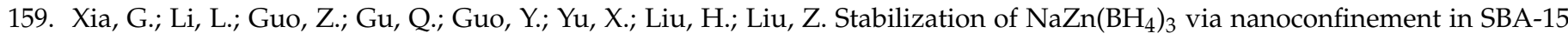
towards enhanced hydrogen release. J. Mater. Chem. A 2013, 1, 250-257. [CrossRef]

160. Černý, R.; Ravnsbæk, D.B.; Schouwink, P.; Filinchuk, Y.; Penin, N.; Teyssier, J.; Smrčok, L.; Jensen, T.R. Potassium zinc borohydrides containing triangular $\left[\mathrm{Zn}\left(\mathrm{BH}_{4}\right)_{3}\right]$-and tetrahedral $\left[\mathrm{Zn}\left(\mathrm{BH}_{4}\right)_{\mathrm{x}} \mathrm{Cl}_{4-\mathrm{x}}\right]^{2-}$ anions. J. Phys. Chem. C 2012, 116, 1563-1571. [CrossRef]

161. Albanese, E.; Kalantzopoulos, G.N.; Vitillo, J.G.; Pinatel, E.; Civalleri, B.; Deledda, S.; Bordiga, S.; Hauback, B.C.; Baricco, M. Theoretical and experimental study on $\mathrm{Mg}\left(\mathrm{BH}_{4}\right)_{2}-\mathrm{Zn}\left(\mathrm{BH}_{4}\right)_{2}$ mixed borohydrides. J. Alloys Compd. 2013, 580, S282-S286. [CrossRef]

162. Kalantzopoulos, G.N.; Vitillo, J.G.; Albanese, E.; Pinatel, E.; Civalleri, B.; Deledda, S.; Bordiga, S.; Baricco, M.; Hauback, B.C. Hydrogen storage of Mg-Zn mixed metal borohydrides. J. Alloys Compd. 2014, 615, S702-S705. [CrossRef]

163. Albanese, E.; Civalleri, B.; Casassa, S.; Baricco, M. Investigation on the decomposition enthalpy of novel mixed $\mathrm{Mg}_{(1-\mathrm{x})} \mathrm{Zn}_{\mathrm{x}}\left(\mathrm{BH}_{4}\right)_{2}$ borohydrides by means of periodic DFT calculations. J. Phys. Chem. C 2014, 118, 23468-23475. [CrossRef]

164. Ravnsbæk, D.B.; Sørensen, L.H.; Filinchuk, Y.; Reed, D.; Book, D.; Jakobsen, H.J.; Besenbacher, F.; Skibsted, J.; Jensen, T.R. Mixed-anion and mixed-cation borohydride $\mathrm{KZn}\left(\mathrm{BH}_{4}\right) \mathrm{Cl}_{2}$ : Synthesis, structure and thermal decomposition. Eur. J. Inorg. Chem. 2010, 1608-1612. [CrossRef]

165. Wiberg, E.; Henle, W. Zur Kenntnis eines Cadmium-bor-wasserstoffs Cd( $\left(\mathrm{BH}_{4}\right)_{2}$. Z. Naturforschg. B 1952, 7, 582. [CrossRef]

166. Nöth, H.; Winter, L.P. Metallboranate und Boranato-metallate. V. Solvate des Cadmiumboranats und Boranatocadmate. Z. Anorg. Allg. Chemie 1972, 389, 225-234. [CrossRef]

167. Ravnsbaek, D.B.; Sørensen, L.H.; Filinchuk, Y.; Besenbacher, F.; Jensen, T.R. Screening of Metal Borohydrides by Mechanochemistry and Diffraction. Angew. Chemie Int. Ed. 2012, 51, 3582-3586. [CrossRef] [PubMed]

168. Blanchard, D.; Zatti, M.; Vegge, T. Analysis of the decomposition gases from $\alpha$ and $\beta-\mathrm{Cd}\left(\mathrm{BH}_{4}\right)_{2}$ synthesized by temperature controlled mechanical milling. J. Alloys Compd. 2013, 547, 76-80. [CrossRef]

169. Nöth, H.; Thomann, M. Metal Tetrahydroborates and Tetrahydroborato Metalates, 17/Bonding in Cadmium Bis(tetrahydroborate), and the Reaction with Lithium Tetrahydroborate. Z. Naturforsch. B 1990, 45, 1482-1486. [CrossRef]

170. Linti, G.; Nöth, H.; Thomann, M. Metal Tetrahydroborates and Tetrahydroborato Metalates, 15 [1] An ${ }^{11} \mathrm{~B}$ and ${ }^{113} \mathrm{Cd}$ NMR Study of $\mathrm{MBH}_{4}-\mathrm{CdCl}_{2}$ Systems in Dimethylformamide and the X-Ray Structure of $\mathrm{CdCl}_{2} \cdot 2 \mathrm{DMF}$. Z. Naturforsch. Sect. B J. Chem. Sci. 1990, 45, 1463-1471. [CrossRef] 
171. Nöth, H.; Thomann, M. Metal Tetrahydroborates and Tetrahydroboratometalates, 18 [1] Studies on the Formation of Cadmium(II)tetrahydroborates with Tetrahydroborate and Iodide. Z. Naturforsch. Sect. B J. Chem. Sci. 1994, 49, 9-14. [CrossRef]

172. Schlesinger, H.I.; Sanderson, R.T.; Burg, A.B. A Volatile Compound of Aluminum, Boron and Hydrogen. J. Am. Chem. Soc. 1939, 61, 536. [CrossRef]

173. Schlesinger, H.I.; Sanderson, R.T.; Burg, A.B. Metallo Borohydrides. I. Aluminum Borohydride. J. Am. Chem. Soc. 1940, 62, 3421-3425. [CrossRef]

174. Rulon, R.M.; Mason, L.S. The Heat of Formation of Aluminum Borohydride. J. Am. Chem. Soc. 1951, 73, 5491-5493. [CrossRef]

175. Schlesinger, H.I.; Brown, H.C.; Hyde, E.K. The Preparation of Other Borohydrides by Metathetical Reactions Utilizing the Alkali Metal Borohydrides. J. Am. Chem. Soc. 1953, 75, 209-213. [CrossRef]

176. Aldridge, S.; Blake, A.J.; Downs, A.J.; Gould, R.O.; Parsons, S.; Pulham, C.R. Some tetrahydroborate derivatives of aluminium: Crystal structures of dimethylaluminium tetrahydroborate and the $\alpha$ and $\beta$ phases of aluminium tris(tetrahydroborate) at low temperature. J. Chem. Soc. Dalt. Trans. 1997, 1007-1012. [CrossRef]

177. Almenningen, A.; Gundersen, G.; Haaland, A.; Haug, A.; Enzell, C.; Francis, G. On the Molecular Structure of Aluminium Borohydride, $\mathrm{Al}\left(\mathrm{BH}_{4}\right)_{3}$. Acta Chem. Scand. 1968, 22, 328-334. [CrossRef]

178. Bauer, S.H.; Bauer, S.H. The Structure of the Hydrides of Boron. VI. AlB ${ }_{3} \mathrm{H}_{12}$. J. Am. Chem. Soc. 1940, 62, 3440-3442.

179. Coe, D.A.; Nibler, J.W. Infrared and Raman spectra of aluminum borohydride, $\mathrm{Al}\left(\mathrm{BH}_{4}\right)_{3}$. Spectrochim. Acta Part A Mol. Spectrosc. 1973, 29, 1789-1804. [CrossRef]

180. Al-Kahtani, A.; Williams, D.L.; Nibler, J.W.; Sharpe, S.W. High-resolution infrared studies of $\mathrm{Al}\left(\mathrm{BH}_{4}\right)_{3}$ and $\mathrm{Al}\left(\mathrm{BD}_{4}\right)_{3}$. J. Phys. Chem. A 1998, 102, 537-544. [CrossRef]

181. Miwa, K.; Ohba, N.; Towata, S.I.; Nakamori, Y.; Züttel, A.; Orimo, S. Ichi First-principles study on thermodynamical stability of metal borohydrides: Aluminum borohydride $\mathrm{Al}\left(\mathrm{BH}_{4}\right)_{3}$. J. Alloys Compd. 2007, 446-447, 310-314. [CrossRef]

182. Harrison, D.; Thonhauser, T. Suppressing diborane production during the hydrogen release of metal borohydrides: The example of alloyed $\mathrm{Al}\left(\mathrm{BH}_{4}\right)_{3}$. Int. J. Hydrog. Energy 2016, 41, 3571-3578. [CrossRef]

183. Paduani, C.; Wu, M.M.; Willis, M.; Jena, P. Theoretical study of the stability and electronic structure of $\mathrm{Al}\left(\mathrm{BH}_{4}\right)_{\mathrm{n}=1 \rightarrow 4}$ and $\mathrm{Al}\left(\mathrm{BF}_{4}\right)_{\mathrm{n}=1 \rightarrow 4}$ and their hyperhalogen behavior. J. Phys. Chem. A 2011, 115, 10237-10243. [CrossRef]

184. Dovgaliuk, I.; Safin, D.A.; Tumanov, N.A.; Morelle, F.; Moulai, A.; Černý, R.; Łodziana, Z.; Devillers, M.; Filinchuk, Y. Solid Aluminum Borohydrides for Prospective Hydrogen Storage. ChemSusChem 2017, 10, 4725-4734. [CrossRef]

185. Dovgaliuk, I.; Ban, V.; Sadikin, Y.; Černý, R.; Aranda, L.; Casati, N.; Devillers, M.; Filinchuk, Y. The first halide-free bimetallic aluminum borohydride: Synthesis, structure, stability, and decomposition pathway. J. Phys. Chem. C 2014, 118, 145-153. [CrossRef]

186. Lindemann, I.; Ferrer, R.D.; Dunsch, L.; Filinchuk, Y.; Černý, R.; Hagemann, H.; D’Anna, V.; Daku, L.M.L.; Schultz, L.; Gutfleisch, O. $\mathrm{Al}_{3} \mathrm{Li}_{4}\left(\mathrm{BH}_{4}\right)_{13}$ : A complex double-cation borohydride with a new structure. Chem. A Eur. J. 2010, 16, 8707-8712. [CrossRef] [PubMed]

187. Lindemann, I.; Borgschulte, A.; Callini, E.; Züttel, A.; Schultz, L.; Gutfleisch, O. Insight into the decomposition pathway of the complex hydride $\mathrm{Al}_{3} \mathrm{Li}_{4}\left(\mathrm{BH}_{4}\right)_{13}$. Int. J. Hydrog. Energy 2013, 38, 2790-2795. [CrossRef]

188. Knight, D.A.; Zidan, R.; Lascola, R.; Mohtadi, R.; Ling, C.; Sivasubramanian, P.; Kaduk, J.A.; Hwang, S.J.; Samanta, D.; Jena, P. Synthesis, characterization, and atomistic modeling of stabilized highly pyrophoric $\mathrm{Al}\left(\mathrm{BH}_{4}\right)_{3}$ via the formation of the hypersalt $\mathrm{K}\left[\mathrm{Al}\left(\mathrm{BH}_{4}\right)_{4}\right]$. J. Phys. Chem. C 2013, 117, 19905-19915. [CrossRef]

189. Downs, A.J.; Thomas, P.D.P. Gallium borohydrides: The synthesis and properties of $\mathrm{HGa}_{(}\left(\mathrm{BH}_{4}\right)_{2}$. J. Chem. Soc. Chem. Commun. 1976, 825. [CrossRef]

190. Pulham, C.R.; Brain, P.T.; Downs, A.J.; Rankin, D.W.H.; Robertson, H.E. Gallaborane, $\mathrm{H}_{2} \mathrm{Ga}(\mu-\mathrm{H})_{2} \mathrm{BH}_{2}$ : Synthesis, properties, and structure of the gaseous molecule as determined by electron diffraction. J. Chem. Soc., Chem. Commun. 1990, 177-178. [CrossRef]

191. Barlow, M.T.; Dain, C.J.; Downs, A.J.; Laurenson, G.S.; Rankin, D.W.H. Group 3 tetrahydroborates. Part 4. The molecular structure of hydridogallium bis(tetrahydroborate) in the gas phase as determined by electron diffraction. J. Chem. Soc. Dalt. Trans. 1982, 597. [CrossRef]

192. Downs, A.J.; Harman, L.A.; Thomas, P.D.P.; Pulham, C.R. Hydridogallium bis(tetrahydroborate), $\mathrm{HGa}_{(}\left(\mathrm{BH}_{4}\right)_{2}$ : $\mathrm{Synthesis}$ and properties. Polyhedron 1995, 14, 935-945. [CrossRef]

193. Wiberg, E.; Nöth, H. Notizen: Über Wasserstoff-Verbindungen des Indiums. Z. Naturforsch. B 1957, 12, 59-60. [CrossRef]

194. Wiberg, E.; Dittmann, O.; Nöth, H.; Schmidt, M. Notizen: Über Wasserstoff-Verbindungen des Thalliums. V. Zur Kenntnis eines Thallium(I)-boranats TlBH4 und Thallium(I)-alanats TlAlH4. Z. Naturforsch. B 1957, 12, 62-63. [CrossRef]

195. Wiberg, E.; Nöth, H. Notizen: Über Wasserstoff-Verbindungen des Thalliums. VI. Zur Kenntnis eines Thallium(III)-boranats TlCl(BH4)2. Z. Naturforsch. B 1957, 12, 63-65. [CrossRef]

196. Stadie, N.P.; Callini, E.; Richter, B.; Jensen, T.R.; Borgschulte, A.; Züttel, A. Supercritical $\mathrm{N}_{2}$ processing as a route to the clean dehydrogenation of porous $\mathrm{Mg}\left(\mathrm{BH}_{4}\right)_{2}$. J. Am. Chem. Soc. 2014, 136, 8181-8184. [CrossRef]

197. Frommen, C.; Sørby, M.; Heere, M.; Humphries, T.; Olsen, J.; Hauback, B. Rare Earth Borohydrides—Crystal Structures and Thermal Properties. Energies 2017, 10, 2115. [CrossRef]

198. Olsen, J.E.; Frommen, C.; Sørby, M.H.; Hauback, B.C. Crystal structures and properties of solvent-free $\left.\mathrm{LiYb}_{(\mathrm{BH}}\right)_{4-\mathrm{x}} \mathrm{Cl}_{\mathrm{x}}, \mathrm{Yb}\left(\mathrm{BH}_{4}\right)_{3}$ and $\mathrm{Yb}\left(\mathrm{BH}_{4}\right)_{2-\mathrm{x}} \mathrm{Cl}_{\mathrm{x}}$. RSC Adv. 2013, 3, 10764-10774. [CrossRef] 
199. Zhang, B.J.; Liu, B.H.; Li, Z.P. Destabilization of $\mathrm{LiBH}_{4}$ by $(\mathrm{Ce}, \mathrm{La})(\mathrm{Cl}, \mathrm{F})_{3}$ for hydrogen storage. J. Alloys Compd. 2011, 509, 751-757. [CrossRef]

200. Ley, M.B.; Jørgensen, M.; Černý, R.; Filinchuk, Y.; Jensen, T.R. From $\mathrm{M}\left(\mathrm{BH}_{4}\right)_{3}(\mathrm{M}=\mathrm{La}, \mathrm{Ce})$ Borohydride Frameworks to Controllable Synthesis of Porous Hydrides and Ion Conductors. Inorg. Chem. 2016, 55, 9748-9756. [CrossRef]

201. GharibDoust, S.H.P.; Brighi, M.; Sadikin, Y.; Ravnsbæk, D.B.; Černý, R.; Skibsted, J.; Jensen, T.R. Synthesis, Structure, and Li-Ion Conductivity of $\operatorname{LiLa}\left(\mathrm{BH}_{4}\right)_{3} \mathrm{X}, \mathrm{X}=\mathrm{Cl}, \mathrm{Br}$, I. J. Phys. Chem. C 2017, 121, 19010-19021. [CrossRef]

202. Payandeh Gharibdoust, S.; Heere, M.; Sørby, M.H.; Ley, M.B.; Ravnsbæk, D.B.; Hauback, B.C.; Černý, R.; Jensen, T.R. Synthesis, structure and properties of new bimetallic sodium and potassium lanthanum borohydrides. Dalt. Trans. 2016, 45, 19002-19011. [CrossRef] [PubMed]

203. Brighi, M.; Schouwink, P.; Sadikin, Y.; Černý, R. Fast ion conduction in garnet-type metal borohydrides $\mathrm{Li}_{3} \mathrm{~K}_{3} \mathrm{Ce}_{2}\left(\mathrm{BH}_{4}\right)_{12}$ and $\mathrm{Li}_{3} \mathrm{~K}_{3} \mathrm{La}_{2}\left(\mathrm{BH}_{4}\right)_{12}$. J. Alloys Compd. 2016, 662, 388-395. [CrossRef]

204. Payandeh Gharibdoust, S.; Ravnsbæk, D.B.; Černý, R.; Jensen, T.R. Synthesis, structure and properties of bimetallic sodium rare-earth (RE) borohydrides, $\mathrm{NaRE}\left(\mathrm{BH}_{4}\right)_{4}, \mathrm{RE}=\mathrm{Ce}, \mathrm{Pr}$, Er or Gd. Dalt. Trans. 2017, 46, 13421-13431. [CrossRef] [PubMed]

205. Gennari, F.C.; Esquivel, M.R. Synthesis and dehydriding process of crystalline $\mathrm{Ce}\left(\mathrm{BH}_{4}\right)_{3}$. J. Alloys Compd. 2009,485 , 47-51. [CrossRef]

206. Luo, X.; Aguey-Zinsou, K.-F. Correlations between the ionic conductivity and cation size in complex borohydrides. Ionics 2020, 26, 5287-5291. [CrossRef]

207. Wu, H. Strategies for the Improvement of the Hydrogen Storage Properties of Metal Hydride Materials. ChemPhysChem 2008, 9 , 2157-2162. [CrossRef]

208. Davies, R.A.; Hewett, D.R.; Anderson, P.A. Enhancing ionic conductivity in lithium amide for improved energy storage materials. Adv. Nat. Sci. Nanosci. Nanotechnol. 2014, 6, 015005. [CrossRef]

209. Anderson, P.A.; Chater, P.A.; Hewett, D.R.; Slater, P.R. Hydrogen storage and ionic mobility in amide-halide systems. Faraday Discuss. 2011, 151, 271. [CrossRef] [PubMed]

210. Gennari, F.C.; Albanesi, L.F.; Puszkiel, J.A.; Larochette, P.A. Reversible hydrogen storage from $6 \mathrm{LiBH}_{4}-\mathrm{MCl}_{3}(\mathrm{M}=\mathrm{Ce}, \mathrm{Gd})$ composites by in-situ formation of $\mathrm{MH}_{2}$. Int. J. Hydrog. Energy 2011, 36, 563-570. [CrossRef]

211. Heere, M.; Payandeh GharibDoust, S.H.; Frommen, C.; Humphries, T.D.; Ley, M.B.; Sørby, M.H.; Jensen, T.R.; Hauback, B.C. The influence of $\mathrm{LiH}$ on the rehydrogenation behavior of halide free rare earth $(\mathrm{RE})$ borohydrides $(\mathrm{RE}=\mathrm{Pr}, \mathrm{Er})$. Phys. Chem. Chem. Phys. 2016, 18, 24387-24395. [CrossRef]

212. Humphries, T.D.; Ley, M.B.; Frommen, C.; Munroe, K.T.; Jensen, T.R.; Hauback, B.C. Crystal structure and in situ decomposition of $\mathrm{Eu}\left(\mathrm{BH}_{4}\right)_{2}$ and $\mathrm{Sm}\left(\mathrm{BH}_{4}\right)_{2}$. J. Mater. Chem. A 2015, 3, 691-698. [CrossRef]

213. Møller, K.T.; Jørgensen, M.; Fogh, A.S.; Jensen, T.R. Perovskite alkali metal samarium borohydrides: Crystal structures and thermal decomposition. Dalt. Trans. 2017, 46, 11905-11912. [CrossRef]

214. Olsen, J.E.; Frommen, C.; Jensen, T.R.; Riktor, M.D.; Sørby, M.H.; Hauback, B.C. Structure and thermal properties of composites with RE-borohydrides (RE = La, Ce, Pr, Nd, Sm, Eu, Gd, Tb, Er, Yb or Lu) and $\mathrm{LiBH}_{4}$. RSC Adv. 2014, 4, 1570-1582. [CrossRef]

215. Sharma, M.; Didelot, E.; Spyratou, A.; Lawson Daku, L.M.; Černý, R.; Hagemann, H. Halide Free $\mathrm{M}\left(\mathrm{BH}_{4}\right)_{2}(\mathrm{M}=\mathrm{Sr}$, Ba, and Eu) Synthesis, Structure, and Decomposition. Inorg. Chem. 2016, 55, 7090-7097. [CrossRef]

216. Rossmanith, K. Herstellung von Europium(II)-bromid-boranat. Monatshefte für Chemie 1966, 97, 863-865. [CrossRef]

217. Borisov, V.D.; Makahaev, A.P. tetrahydridoborates of divalent Samarium, Europium, and Ytterbium. Russ. J. Inorg. Chem. 1999, 44, 1411-1413.

218. Andrade-Gamboa, J.; Puszkiel, J.A.; Fernández-Albanesi, L.; Gennari, F.C. A novel polymorph of gadolinium tetrahydroborate produced by mechanical milling. Int. J. Hydrog. Energy 2010, 35, 10324-10328. [CrossRef]

219. Ley, M.B.; Paskevicius, M.; Schouwink, P.; Richter, B.; Sheppard, D.A.; Buckley, C.E.; Jensen, T.R. Novel solvates $\mathrm{M}\left(\mathrm{BH}_{4}\right)_{3} \mathrm{~S}\left(\mathrm{CH}_{3}\right)_{2}$ and properties of halide-free $\mathrm{M}\left(\mathrm{BH}_{4}\right)_{3}(\mathrm{M}=\mathrm{y}$ or $\mathrm{Gd})$. Dalt. Trans. 2014, 43, 13333-13342. [CrossRef]

220. Wegner, W.; Jaroń, T.; Grochala, W. Polymorphism and hydrogen discharge from holmium borohydride, $\mathrm{Ho}_{(}\left(\mathrm{BH}_{4}\right)_{3}$, and $\mathrm{KHo}\left(\mathrm{BH}_{4}\right)_{4}$. Int. J. Hydrog. Energy 2014, 39, 20024-20030. [CrossRef]

221. Wegner, W.; Jaroń, T.; Grochala, W. $\mathrm{MYb}\left(\mathrm{BH}_{4}\right)_{4}(\mathrm{M}=\mathrm{K}, \mathrm{Na})$ from laboratory X-ray powder data. Acta Crystallogr. Sect. C Cryst. Struct. Commun. 2013, 69, 1289-1291. [CrossRef] [PubMed]

222. Banks, R.H.; Edelstein, N.M. Synthesis and Characterization of Protactinium(IV), Neptunium(IV), and Plutonium (IV) Borohydrides. In Lanthanide and Actinide Chemistry and Spectroscopy; American Chemical Society Publications: Washington, DC, USA, 1980; pp. 331-348. [CrossRef]

223. Rajnak, K.; Gamp, E.; Shinomoto, R.; Edelstein, N. Optical and magnetic properties of uranium borohydride and tetrakismethylborohydride. J. Chem. Phys. 1984, 80, 5942-5950. [CrossRef]

224. Bernstein, E.R.; Hamilton, W.C.; Keiderling, T.A.; La Placa, S.J.; Lippard, S.J.; Mayerle, J.J. 14-Coordinate uranium(IV). Structure of uranium borohydride by single-crystal neutron diffraction. Inorg. Chem. 1972, 11, 3009-3016. [CrossRef]

225. Banks, R.H.; Edelstein, N.M.; Rietz, R.R.; Templeton, D.H.; Zalkin, A. Preparation and properties of the actinide borohydrides: Protactinium(IV), neptunium(IV), and plutonium(IV) borohydrides. J. Am. Chem. Soc. 1978, 100, 1957-1958. [CrossRef]

226. Schlesinger, H.I.; Brown, H.C. Uranium(IV) Borohydride 1. J. Am. Chem. Soc. 1953, 75, 219-221. [CrossRef]

227. Bernstein, E.R.; Keiderling, T.A. Optical and magnetic resonance spectra of inorganic molecular crystals-uranium borohydride $\left[\mathrm{U}\left(\mathrm{BH}_{4}\right)_{4}\right]$ in hafnium borohydride $\left[\mathrm{Hf}\left(\mathrm{BH}_{4}\right)_{4}\right]$. J. Chem. Phys. 1973, 59, 2105-2122. [CrossRef] 
228. Ghiassee, N.; Clay, P.G.; Walton, G.N. Photolytic decomposition of uranium tetrahydroborate vapour, $\mathrm{U}\left(\mathrm{BH}_{4}\right)_{4}$. Inorg. Nucl. Chem. Lett. 1980, 16, 149-153. [CrossRef]

229. Ghiassee, N.; Clay, P.G.; Walton, G.N. Thermal decomposition of U(BH $\left.)_{4}\right)_{4}$. J. Inorg. Nucl. Chem. 1981, 43, 2909-2913. [CrossRef]

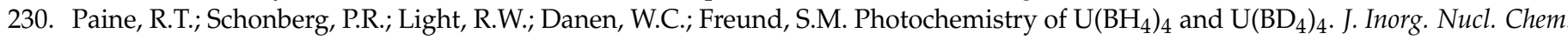
1979, 41, 1577-1578. [CrossRef]

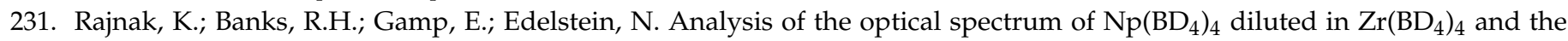
magnetic properties of $\mathrm{Np}\left(\mathrm{BH}_{4}\right)_{4}$ and $\mathrm{Np}\left(\mathrm{BH}_{3} \mathrm{CH}_{3}\right)_{4}$. J. Chem. Phys. 1984, 80, 5951-5962. [CrossRef]

232. Schlapbach, L.; Züttel, A. Hydrogen-storage materials for mobile applications. Nature 2001, 414, 353-358. [CrossRef] [PubMed]

233. Li, H.W.; Orimo, S.; Nakamori, Y.; Miwa, K.; Ohba, N.; Towata, S.; Züttel, A. Materials designing of metal borohydrides: Viewpoints from thermodynamical stabilities. J. Alloys Compd. 2007, 446-447, 315-318. [CrossRef]

234. Błoński, P.; Łodziana, Z. Correlation between the ionic potential and thermal stability of metal borohydrides: First-principles investigations. Phys. Rev. B 2014, 90, 054114. [CrossRef]

235. Łodziana, Z.; Błoński, P.; Yan, Y.; Rentsch, D.; Remhof, A. NMR Chemical Shifts of ${ }^{11}$ B in Metal Borohydrides from First-Principle Calculations. J. Phys. Chem. C 2014, 118, 6594-6603. [CrossRef]

236. Mauron, P.; Buchter, F.; Friedrichs, O.; Remhof, A.; Bielmann, M.; Zwicky, C.N.; Züttel, A. Stability and reversibility of LiBH 4 . J. Phys. Chem. B 2008, 112, 906-910. [CrossRef]

237. Züttel, A.; Rentsch, S.; Fischer, P.; Wenger, P.; Sudan, P.; Mauron, P.; Emmenegger, C. Hydrogen storage properties of LiBH 4 . J. Alloys Compd. 2003, 356-357, 515-520. [CrossRef]

238. Liu, H.; Wang, X.; Zhou, H.; Gao, S.; Ge, H.; Li, S.; Yan, M. Improved hydrogen desorption properties of $\mathrm{LiBH}_{4}$ by $\mathrm{AlH}_{3}$ addition. Int. J. Hydrog. Energy 2016, 41, 22118-22127. [CrossRef]

239. Zhang, B.J.; Liu, B.H. Hydrogen desorption from $\mathrm{LiBH}_{4}$ destabilized by chlorides of transition metal Fe, Co, and Ni. Int. J. Hydrog. Energy 2010, 35, 7288-7294. [CrossRef]

240. Yu, X.B.; Grant, D.M.; Walker, G.S. Dehydrogenation of $\mathrm{LiBH}_{4}$ Destabilized with Various Oxides. J. Phys. Chem. C 2009, 113, 17945-17949. [CrossRef]

241. Ngene, P.; van den Berg, R.; Verkuijlen, M.H.W.; de Jong, K.P.; de Jongh, P.E. Reversibility of the hydrogen desorption from $\mathrm{NaBH}_{4}$ by confinement in nanoporous carbon. Energy Environ. Sci. 2011, 4, 4108. [CrossRef]

242. Martelli, P.; Caputo, R.; Remhof, A.; Mauron, P.; Borgschulte, A.; Züttel, A. Stability and decomposition of NaBH 4 . J. Phys. Chem. C 2010, 114, 7173-7177. [CrossRef]

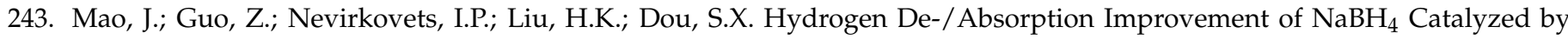
Titanium-Based Additives. J. Phys. Chem. C 2012, 116, 1596-1604. [CrossRef]

244. Mao, J.F.; Yu, X.B.; Guo, Z.P.; Liu, H.K.; Wu, Z.; Ni, J. Enhanced hydrogen storage performances of $\mathrm{NaBH}_{4}-\mathrm{MgH}_{2} \mathrm{system}$ J. Alloys Compd. 2009, 479, 619-623. [CrossRef]

245. Kumar, S.; Jain, A.; Miyaoka, H.; Ichikawa, T.; Kojima, Y. Study on the thermal decomposition of $\mathrm{NaBH}_{4} \mathrm{catalyzed} \mathrm{by} \mathrm{ZrCl}_{4}$. Int J. Hydrog. Energy 2017, 42, 22432-22437. [CrossRef]

246. Mao, J.F.; Yu, X.B.; Guo, Z.P.; Poh, C.K.; Liu, H.K.; Wu, Z.; Ni, J. Improvement of the $\mathrm{LiAlH}_{4}-\mathrm{NaBH}_{4}$ system for reversible hydrogen storage. J. Phys. Chem. C 2009, 113, 10813-10818. [CrossRef]

247. Kumar, S.; Kojima, Y.; Dey, G.K. Synergic effect of $\mathrm{ZrCl}_{4}$ on thermal dehydrogenation kinetics of $\mathrm{KBH}_{4}$. J. Alloys Compd. 2017, 718, 134-138. [CrossRef]

248. Dematteis, E.M.; Santoru, A.; Poletti, M.G.; Pistidda, C.; Klassen, T.; Dornheim, M.; Baricco, M. Phase stability and hydrogen desorption in a quinary equimolar mixture of light-metals borohydrides. Int. J. Hydrog. Energy 2018, 43, 16793-16803. [CrossRef]

249. Ley, M.B.; Roedern, E.; Jensen, T.R. Eutectic melting of $\mathrm{LiBH}_{4}-\mathrm{KBH}_{4}$. Phys. Chem. Chem. Phys. 2014, 16, 24194-24199. [CrossRef]

250. Züttel, A.; Borgschulte, A.; Orimo, S.I. Tetrahydroborates as new hydrogen storage materials. Scr. Mater. 2007, 56, 823-828. [CrossRef]

251. Newhouse, R.J.; Stavila, V.; Hwang, S.-J.; Klebanoff, L.E.; Zhang, J.Z. Reversibility and Improved Hydrogen Release of Magnesium Borohydride. J. Phys. Chem. C 2010, 114, 5224-5232. [CrossRef]

252. Soloveichik, G.; Gao, Y.; Rijssenbeek, J.; Andrus, M.; Kniajanski, S.; Bowmanjr, R.; Hwang, S.; Zhao, J. Magnesium borohydride as a hydrogen storage material: Properties and dehydrogenation pathway of unsolvated $\mathrm{Mg}\left(\mathrm{BH}_{4}\right)_{2}$. Int. J. Hydrog. Energy 2009, 34, 916-928. [CrossRef]

253. Matsunaga, T.; Buchter, F.; Miwa, K.; Towata, S.; Orimo, S.; Züttel, A. Magnesium borohydride: A new hydrogen storage material. Renew. Energy 2008, 33, 193-196. [CrossRef]

254. Dematteis, E.M.; Baricco, M. Hydrogen Desorption in $\mathrm{Mg}\left(\mathrm{BH}_{4}\right)_{2}-\mathrm{Ca}\left(\mathrm{BH}_{4}\right)_{2}$ System. Energies 2019, 12, 3230. [CrossRef]

255. Chu, H.; Wu, G.; Zhang, Y.; Xiong, Z.; Guo, J.; He, T.; Chen, P. Improved dehydrogenation properties of calcium borohydride combined with alkaline-earth metal amides. J. Phys. Chem. C 2011, 115, 18035-18041. [CrossRef]

256. Comănescu, C.; Capurso, G.; Maddalena, A. Nanoconfinement in activated mesoporous carbon of calcium borohydride for improved reversible hydrogen storage. Nanotechnology 2012, 23, 385401. [CrossRef]

257. Rönnebro, E.; Majzoub, E.H. Calcium borohydride for hydrogen storage: Catalysis and reversibility. J. Phys. Chem. B 2007, 111, 12045-12047. [CrossRef] [PubMed]

258. Chu, H.; Wu, G.; Xiong, Z.; Guo, J.; He, T.; Chen, P. Structure and Hydrogen Storage Properties of Calcium Borohydride Diammoniate. Chem. Mater. 2010, 22, 6021-6028. [CrossRef] 
259. Ravnsbæk, D.B.; Nickels, E.A.; Černý, R.; Olesen, C.H.; David, W.I.F.; Edwards, P.P.; Filinchuk, Y.; Jensen, T.R. Novel Alkali Earth Borohydride $\mathrm{Sr}\left(\mathrm{BH}_{4}\right)_{2}$ and Borohydride-Chloride $\mathrm{Sr}\left(\mathrm{BH}_{4}\right) \mathrm{Cl}$. Inorg. Chem. 2013, 52, 10877-10885. [CrossRef] [PubMed]

260. Wiberg, E.; Nöth, H.; Hartwimmer, R. Notizen: Zur Kenntnis von Erdalkaliboranaten $\mathrm{Me}\left[\mathrm{BH} \mathrm{H}_{4}\right]_{2}$. Z. Naturforsch. B 1955, 10, 292-294. [CrossRef]

261. Borgschulte, A.; Callini, E.; Probst, B.; Jain, A.; Kato, S.; Friedrichs, O.; Remhof, A.; Bielmann, M.; Ramirez-Cuesta, A.J.; Züttel, A. Impurity gas analysis of the decomposition of complex hydrides. J. Phys. Chem. C 2011, 115, 17220-17226. [CrossRef]

262. Callini, E.; Borgschulte, A.; Ramirez-cuesta, J.; Züttel, A. Diborane release and structure distortion in borohydrides. Dalton Trans. 2012, 2, 719-725. [CrossRef]

263. Pitt, M.P.; Paskevicius, M.; Brown, D.H.; Sheppard, D.A.; Buckley, C.E. Thermal stability of $\mathrm{Li}_{2} \mathrm{~B}_{12} \mathrm{H}_{12}$ and its role in the decomposition of $\mathrm{LiBH}_{4}$. J. Am. Chem. Soc. 2013, 135, 6930-6941. [CrossRef] [PubMed]

264. Friedrichs, O.; Remhof, A.; Hwang, S.J.; Züttel, A. Role of $\mathrm{Li}_{2} \mathrm{~B}_{12} \mathrm{H}_{12}$ for the formation and decomposition of LiBH4 . Chem. Mater. 2010, 22, 3265-3268. [CrossRef]

265. Her, J.H.; Yousufuddin, M.; Zhou, W.; Jalisatgi, S.S.; Kulleck, J.G.; Zan, J.A.; Hwang, S.J.; Bowman, R.C.; Udovic, T.J. Crystal structure of $\mathrm{Li}_{2} \mathrm{~B}_{12} \mathrm{H}_{12}$ : A possible intermediate species in the decomposition of $\mathrm{LiBH}_{4}$. Inorg. Chem. 2008, 47, 9757-9759. [CrossRef] [PubMed]

266. Beall, H.; Gaines, D.F. Mechanistic aspects of boron hydride reactions. Inorg. Chim. Acta 1999, 289, 1-10. [CrossRef]

267. Grahame, A.; Aguey-Zinsou, K.F. Properties and applications of metal (M) dodecahydro-closo-dodecaborates $\left(\mathrm{M}_{\mathrm{n}=1,2} \mathrm{~B}_{12} \mathrm{H}_{12}\right)$ and their implications for reversible hydrogen storage in the borohydrides. Inorganics 2018, 6, 106. [CrossRef]

268. Černý, R.; Brighi, M.; Murgia, F. The Crystal Chemistry of Inorganic Hydroborates. Chemistry 2020, 2, 805-826. [CrossRef]

269. Wong, S.S.; Li, W.K.; Paddon-Row, M.N. On the structure and stability of the $\mathrm{AlH}_{4}$ radical and its potential energy surface for rearrangement and dissociation: An ab initio MO study. J. Mol. Struct. Theochem 1991, 226, 285-301. [CrossRef]

270. Barkhordarian, G.; Klassen, T.; Dornheim, M.; Bormann, R. Unexpected kinetic effect of $\mathrm{MgB}_{2}$ in reactive hydride composites containing complex borohydrides. J. Alloys Compd. 2007, 440, 18-21. [CrossRef]

271. Gennari, F.C. Improved hydrogen storage reversibility of $\mathrm{LiBH}_{4}$ destabilized by $\mathrm{Y}_{(}\left(\mathrm{BH}_{4}\right)_{3}$ and $\mathrm{YH}_{3}$. Int. J. Hydrog. Energy 2012, 37, 18895-18903. [CrossRef]

272. Liu, X.; Peaslee, D.; Jost, C.Z.; Baumann, T.F.; Majzoub, E.H. Systematic Pore-Size Effects of Nanoconfinement of LiBH 4 : Elimination of Diborane Release and Tunable Behavior for Hydrogen Storage Applications. Chem. Mater. 2011, 23, $1331-1336$. [CrossRef] 